\title{
DESEMPENHO E CARACTERIZAÇÃO MICROBIANA DO PROCESSO DE DOIS ESTÁGIOS COM REATORES ANAERÓBIOS DE FLUXO ASOCENDENTE COM MANTA DE LODO (UASB) TRATANDO ÁGUAS RESIDUÁRIAS DE SUINOCULTURA
}

Dissertação apresentada à Escola de Engenharia de São Carlos, da Universidade de São Paulo, como parte dos requisitos para obtenção do título de Mestre em Engenharia Civil - Hidráulica e Saneamento

Orientadora: Profa. Dra. Maria Bernadete Varesche

São Carlos, SP 2004 
"Sem o Homem, isto é, antes da história, a natureza era una. Continua a sê-lo, em si mesma, apesar das partições que o uso do planeta pelos Homens lhe infligiu. Agora, porém, há uma enorme mudança. Una, mas socialmente fragmentada, durante tantos séculos, a natureza é agora unificada pela História, em beneficio de firmas, estados e classes hegemônicas. Mas não é mais a Natureza Amiga, e o Homem também não é mais seu amigo".

Santos (1997) 
À minha esposa Selma, a quem

sempre desejei ter ao meu lado, à

minha mãe Maria e ao meu pai José,

Pelo significado que me dão à vida,

DEDICO este trabalho

e todo meu carinho e amor. 


\section{AGRADECIMENTOS}

Meus agradecimentos a todas as pessoas e instituições que contribuíram para a elaboração desta pesquisa. Aos familiares, amigos, colegas de curso e trabalho que me deram muito incentivo e apoio e de maneira especial,

Aos Profs. Drs. Roberto Alves de Oliveira e Maria Bernadete Varesche pela orientação segura, companheirismo, ensinamentos e estímulo.

Aos Profs. Drs. Marcelo Zaiat e Eugênio Foresti pelo apoio, estímulo, companheirismo e pelas sugestões valiosas para o desenvolvimento deste trabalho.

Às técnicas do Laboratório de Processos Biológicos Maria Ângela e Elizabete Moraes pela convivência agradável e pelo apoio na realização das análises.

Às colegas Júlia Shumiko e Izabel Sakamoto pelo auxílio na realização das análises microbiológicas e amizade dentro e fora do ambiente de trabalho.

À técnica do Laboratório de Reuso - LATAR, Ana Paula Paim, pelo apoio na realização das análises e pela amizade durante o período da pesquisa.

Às secretárias do Departamento de Hidráulica e Saneamento (Sá, Pavi e Rose) pela paciência e carinho sempre demonstrados.

Aos colegas do Laboratório de Processos Biológicos, Douglas, Ari, Arnaldo, Neyson, Betão, Fernando, Andréa, Dirlane, Ana Paula Miqueleto, Eduardo Catony, Luis Ricardo, Estela, Luana, Sávia e Sônia Valle pela convivência agradável durante a realização da pesquisa.

Aos amigos Ronan Contrera, Luis Hamilton e Katt Regina pelo apoio, incentivo, amizade e contribuição na redação desta pesquisa. Também pela estadia nas minhas viagens a São Carlos e aos bons pratos e comemorações acontecidos neste período.

Aos amigos Rogers e Samantha pelo apoio e contribuição na elaboração deste trabalho.

Aos amigos da Secretaria do Abastecimento de Curitiba (Braz e Georg) pelo incentivo e apoio direto ou indireto no desenvolvimento deste trabalho.

Ao meu irmão Valmir, meu eterno amigo, a quem sou muito grato pelo desenvolvimento de minhas atividades profissionais no período em que estive ausente.

À CAPES - Coordenação de Aperfeiçoamento de Pessoal de Nível Superior do Ministério da Educação, pelo auxílio financeiro para realização da pesquisa. 


\section{SUMÁRIO}

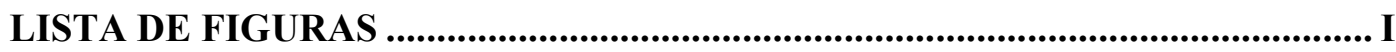

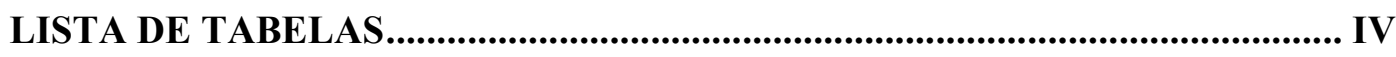

LISTA DE ABREVIATURAS ................................................................ VI

LISTA DE SÍMBOLOS ................................................................................. VII

RESUMO.................................................................................................. VIII

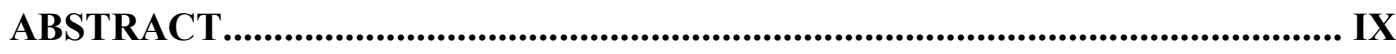

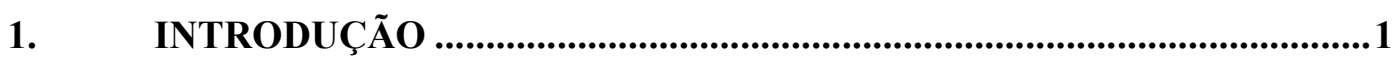

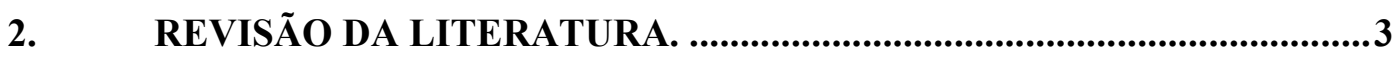

2.1. PROCESSO ANAERÓBIO PARA TRATAMENTO DE ÁGUAS RESIDUÁRIAS. ................ 3

2.2. CARACTERÍSTICAS MICROBIOLÓGICAS DO PROCESSO ANAERÓBIO..................... 3

2.3. REATOR ANAERÓBIO DE FLUXO ASCENDENTE COM MANTA DE LODO

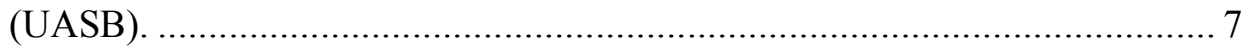

2.4. PROCESSO ANAERÓBIO EM DOIS ESTÁGIOS.............................................. 8

2.5. CARACTERÍSTICAS DOS DEJETOS DE SUÍNOS............................................... 9

2.6. TRATAMENTO DE ÁGUAS RESIDUÁRIAS DE SUINOCULTURA EM REATORES

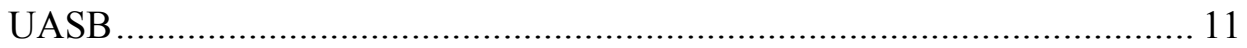

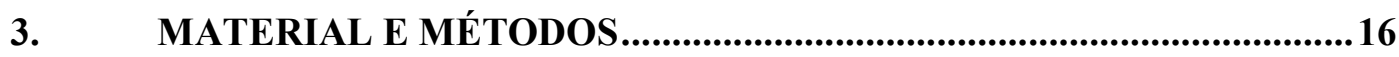

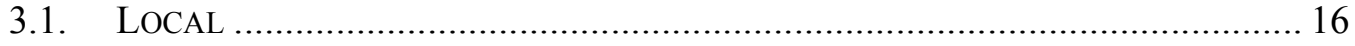

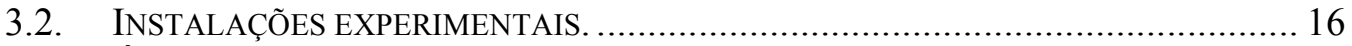

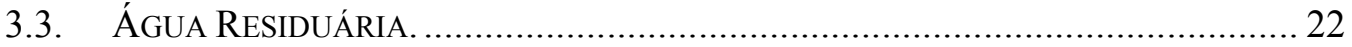

3.4. DESCRIÇÃO DA OPERAÇÃO DO SISTEMA DE TRATAMENTO. ............................ 22

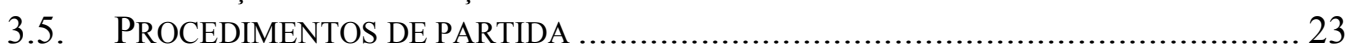

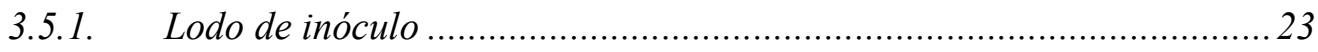

3.5.2. Partida ..................................................................................... 24

3.6. EXAMES FÍSICOS E DETERMINAÇÕES DE CONSTITUINTES ORGÂNICOS E

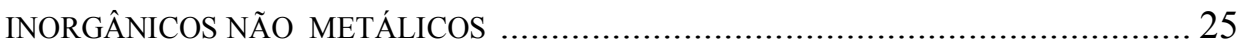

3.6.1. Amostragem ...................................................................... 25

3.6.2. Freqüencia de amostragem e metodologias utilizadas para

monitoramento dos reatores................................................................26

3.7. MANTA DE LODO: EXAMES FÍSICOS E MICROBIOLÓGICOS ................................ 30

3.7.1. Volume da manta e descarte de lodo ...................................................... 30

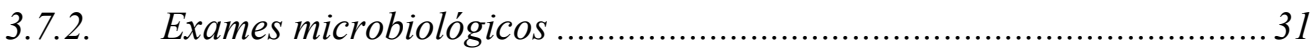

3.8. OPERAÇÕES DE MANUTENÇÃO DA UNIDADE EXPERIMENTAL.......................... 32

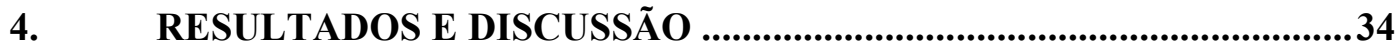

4.1. EXAMES FÍSICOS E DETERMINAÇÕES DE CONSTITUINTES ORGÂNICOS E

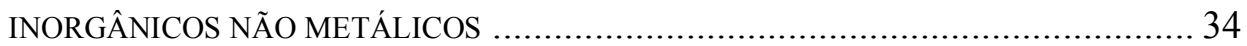

4.1.1. Partida do Sistema ....................................................................... 35

4.1.2. Temperatura da câmara com os reatores $U A S B$................................. 38

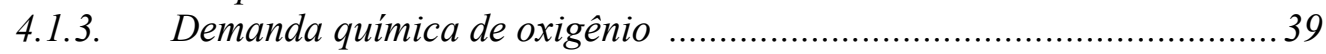

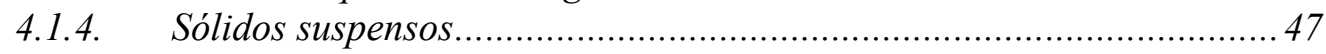

4.1.5. Manta de lodo: sólidos totais e voláteis........................................... 52

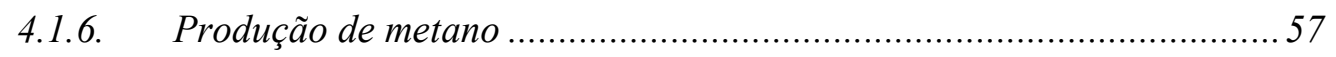


4.1.7. Lodo - produção e taxa de acumulação na manta..................................63

4.1.8. Nitrogênio total, orgânico e amoniacal ...............................................6 65

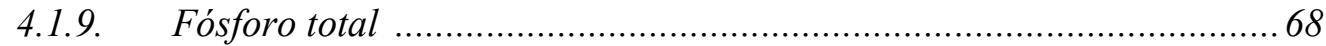

4.1.10. pH, alcalinidade e ácidos voláteis .................................................69 69

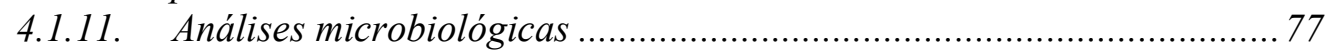

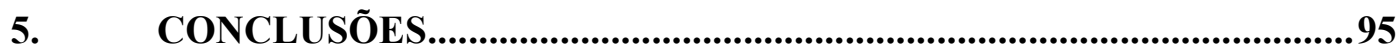

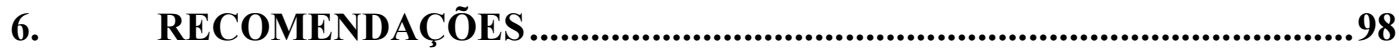

7. REFERÊNCIAS BIBLIOGRÁFICAS ...................................................99 


\section{LISTA DE FIGURAS}

Figura 2.1 Arranjo populacional do grânulo 4

Figura 3.1 Esquema do sistema de dois estágios com reatores UASB de bancada: (1) Reator UASB 39,0 L, (2) Reator UASB 10,5 L, (3) Bomba tipo diafragma, (4) Selo hídrico, (5) Frasco Mariot, (6) Afluente, (7) Efluente, (8) Coletor de líquido deslocado.

Figura 3.2. Vista frontal e superior do primeiro reator UASB $(39,0$ L)Erro! Indicador não definido

Figura 3.3. Vista frontal do separador de gases e amostrador do primeiro reator $\operatorname{UASB}(39,0 \mathrm{~L})$.

Figura 3.4. Vista frontal e superior do segundo reator UASB (10,5 L)

Figura 3.5. Unidade experimental operada com temperatura controlada

Figura 4.1. Concentrações de $\mathrm{DQO}_{\text {total }}$ obtidas na partida do sistema em dois estágios.

Figura 4.2. Concentrações de sólidos suspensos totais (SST) obtidas na partida do sistema em dois estágios.

Figura 4.3. Eficiências de remoção de $\mathrm{DQO}_{\text {total }}$ obtidas na partida do sistema em dois estágios.

Figura 4.4. Eficiências de remoção de sólidos suspensos totais (SST) obtidas na partida do sistema em dois estágios.

Figura 4.5. Concentrações de ácidos voláteis totais (AVT) nos efluentes do primeiro e segundo reatores na partida do sistema em dois estágios.

Figura 4.6. Leituras das temperaturas máxima e mínima do ar durante a operação dos reatores nos ensaios 1,2 e 3 .

Figura 4.7. Concentrações de $\mathrm{DQO}_{\text {total }}$ obtidas no afluente e efluentes do primeiro e segundo reatores nos ensaios 1,2 e 3 . . .

Figura 4.8. Concentrações de $\mathrm{DQO}_{\text {dissolvida }}$ obtidas no afluente e efluentes do primeiro e segundo reatores nos ensaios 1,2 e 3 .

Figura 4.9. Concentrações de DQO devido à fração de sólidos suspensos obtidas no afluente e efluentes do primeiro e segundo reatores nos ensaios 1,2 e $3 \ldots 42$

Figura 4.10. Eficiências de remoção de $\mathrm{DQO}_{\text {total }}$ obtidas no primeiro e segundo reatores nos ensaios 1,2 e 3 .

Figura 4.11. Eficiências de remoção de $\mathrm{DQO}_{\text {dissolvida }}$ obtidas no primeiro e segundo reatores nos ensaios 1,2 e 3 .

Figura 4.12. Eficiências de remoção de DQO devido à fração de sólidos suspensos obtidas no primeiro e segundo reatores nos ensaios 1, 2 e 3 .

Figura 4.13. Concentrações de sólidos suspensos totais (SST) obtidas no afluente e efluentes do primeiro e segundo reatores nos ensaios 1,2 e 3 .

Figura 4.14. Concentrações de sólidos suspensos voláteis (SSV) obtidas no afluente e efluentes do primeiro e segundo reatores nos ensaios 1,2 e 3 . ..............50

Figura 4.15. Concentrações de sólidos suspensos fixos (SSF) obtidas no afluente e efluentes do primeiro e segundo reatores nos ensaios 1,2 e 3 .

Figura 4.16. Eficiências de remoção de SST obtidas no primeiro e segundo reatores nos ensaios 1,2 e 3

Figura 4.17. Eficiências de remoção de SSV obtidas no primeiro e segundo reatores nos ensaios 1,2 e 3 .

Figura 4.18. Concentrações de sólidos totais (ST) obtidos através de perfis da manta do primeiro reator durante a operação do sistema em dois estágios nos ensaios 1, 2 e 3 . 
Figura 4.19. Concentrações de sólidos voláteis (SV) obtidos através de perfis da manta do primeiro reator durante a operação do sistema em dois estágios nos ensaios 1,2 e 3 .

Figura 4.20. Concentrações de sólidos totais (ST) obtidos através de perfis da manta do segundo reator durante a operação do sistema em dois estágios nos ensaios 1,2 e 3

Figura 4.21. Concentrações de sólidos voláteis (SV) obtidos através de perfis da manta do segundo reator durante a operação do sistema em dois estágios

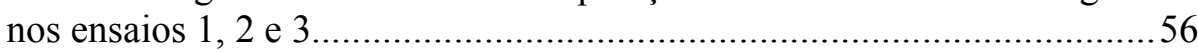

Figura 4.22. Valores de $\mathrm{pH}$ do afluente e efluentes do primeiro e segundo reatores, obtidos nos ensaios 1,2 e 3 .

Figura 4.23. Alcalinidade total (AT) do afluente e efluentes do primeiro e segundo reatores, obtidos nos ensaios 1,2 e 3 .

Figura 4.24. Alcalinidade parcial (AP) do afluente e efluentes do primeiro e segundo reatores, obtidos nos ensaios 1,2 e 3

Figura 4.25. Alcalinidade intermediária (AI) do afluente e efluentes do primeiro e segundo reatores, obtidos nos ensaios 1,2 e 3 .

Figura 4.26. Concentrações de ácidos voláteis totais (AVT) obtidas no afluente e efluentes do primeiro e segundo reatores, nos ensaios 1,2 e 3 .

Figura 4.27. Relação AI:AP nos efluentes do primeiro e segundo reatores, obtidos nos ensaios 1,2 e 3.

Figura 4.28. Relação AVT:AT nos efluentes do primeiro e segundo reatores, obtidos nos ensaios 1,2 e 3 .

Figura 4.29. Morfologias observadas sob microscopia óptica de contraste de fase da manta de lodo do primeiro reator no ensaio 1: (a) bacilos retos em forma de feixe semelhantes à Methanosaeta e (b) cocos.

Figura 4.30. Morfologias observadas sob microscopia óptica de contraste de fase e fluorescência da manta de lodo do primeiro reator no ensaio 2: (a) bacilos retos semelhantes a Methanosaeta, (b) cocos em tétrade, (c) cocos fluorescentes e (d) bacilos fluorescentes.

Figura 4.31. Morfologias observadas sob microscopia óptica de contraste de fase e fluorescência da manta de lodo do primeiro reator no ensaio 3: (a) bacilos retos semelhantes a Methanosaeta, (b) cocos em cadeia, (c) bacilos e cocos e (d) bacilos fluorescentes.

Figura 4.32. Morfologias observadas sob microscopia óptica de contraste de fase da manta de lodo do segundo reator no ensaio 1: (a) bacilos retos semelhantes a Methanosaeta, (b) cocos e (c) filamento septado.

Figura 4.33. Morfologias observadas sob microscopia óptica de contraste de fase e fluorescência da manta de lodo do segundo reator no ensaio 2: (a) bacilos retos semelhantes a Methanosaeta, (b) cocos, (c) bacilos curvos e (d) cocos fluorescentes.

Figura 4.34. Morfologias observadas sob microscopia óptica de contraste de fase e fluorescência da manta de lodo do segundo reator no ensaio 3: (a) bacilos retos semelhantes a Methanosaeta, (b) bacilos com as extremidades arredondadas, (c) bacilos curvos e (d) bacilos fluorescentes.

Figura 4.35. Morfologias observadas sob microscopia óptica de contraste de fase da manta de lodo do primeiro e segundo reatores nos ensaios 1, 2 e 3: (a) filamentos longos com bainha, (b) bacilos com extremidade arredondada, (c) protozoários (c) e (d) amebas. 
Figura 4.36. Microscopia eletrônica de varredura (MEV) do grânulo, cortado transversalmente, da manta de lodo do primeiro reator no final do experimento.

Figura 4.37. Microscopia eletrônica de varredura (MEV) das camadas intermediária (a) e central (b) de grânulos coletados da manta de lodo do primeiro reator, apresentando morfologia semelhante a Methanosaeta.

Figura 4.38. Microscopia eletrônica de varredura (MEV) das camadas intermediária (a) e central (b) de grânulos coletados da manta de lodo do segundo reator, apresentando morfologia semelhante a Methanosaeta.

Figura 4.39. Microscopia eletrônica de varredura (MEV) das camadas intermediária (a) e central (b) de grânulos coletados da manta de lodo do primeiro reator, com predomínio de cocos.

Figura 4.40. Microscopia eletrônica de varredura (MEV) das camadas intermediária (a) e central (b) de grânulos coletados da manta de lodo do primeiro reator, apresentando morfologias semelhantes a Methanosaeta e bacilos ovalados.

Figura 4.41. Microscopia eletrônica de varredura (MEV) das camadas intermediária (a) e central (b) de grânulos coletados da manta de lodo do segundo reator, apresentando predomínio de cocos.

Figura 4.42. Microscopia eletrônica de varredura (MEV) das camadas intermediária (a) e central (b) de grânulos coletados da manta de lodo do segundo reator, apresentando predomínio de bacilos ovalados.

Figura 4.43. Microscopia eletrônica de varredura (MEV) da camada externa de grânulos coletados da manta de lodo do primeiro reator, com bacilos (a) e $\operatorname{cocos}(\mathrm{b})$

Figura 4.44. Microscopia eletrônica de varredura (MEV) da camada externa de grânulos coletados da manta de lodo do segundo reator, apresentando cocos (a) e bacilos ovalados (b) 


\section{LISTA DE TABELAS}

Tabela 2.2 Reatores anaeróbios não convencionais (de alta taxa) tratando águas residuárias de suinocultura: tipo, características, condições de operação e desempenho dos reatores e características da água residuária afluente. .. 13

Tabela 3.1. Condições de operação do primeiro $(\mathrm{r} 1)$ e segundo $(\mathrm{r} 2)$ reator UASB nos ensaios 1,2 e 3 do sistema em dois estágios.

Tabela 3.2. Exames e determinações, freqüência e fontes das metodologias utilizadas.

Tabela 3.3. Variação do volume de amostra de água residuária de suinocultura...........28

Tabela 3.4. Resultados obtidos variando a massa de persulfato de potássio.................29

Tabela 3.5. Relação dos dias de operação nos quais foram realizados descartes de lodo da manta dos reatores UASB.

Tabela 4.1. Valores médios e coeficiente de variação $(\mathrm{CV})$ da $\mathrm{DQO}_{\text {total }}$ e dissolvida do afluente e efluentes, eficiência de remoção de DQO (E) e taxa de carregamento orgânico volumétrico (TCOV), em relação à $\mathrm{DQO}_{\text {total }} \mathrm{e}$ dissolvida, obtidos durante a operação do sistema em dois estágios, primeiro(r1) e segundo (r2) reator, nos ensaios 1,2 e 3.

Tabela 4.2. Valores médios e coeficiente de variação (CV) das concentrações de SST e SSV no afluente e efluente e eficiência de remoção (E), obtidos durante a operação do sistema em dois estágios, primeiro (r1) e segundo

(r2) reatores, nos ensaios 1,2 e 3.

Tabela 4.3. Valores médios de sólidos totais (ST) e voláteis (SV), coeficiente de variação $(\mathrm{CV})$ e taxa de carregamento no lodo (TCL), obtidos através de perfis da manta do primeiro reator durante a operação do sistema em dois estágios nos ensaios 1,2 e 3 .

Tabela 4.4. Valores médios de sólidos totais (ST) e voláteis (SV), coeficiente de variação (CV) e taxa de carregamento no lodo (TCL), obtidos através de perfis da manta do segundo reator durante a operação do sistema em dois estágios nos ensaios 1,2 e 3 .

Tabela 4.5. Valores médios e coeficiente de variação (CV) da porcentagem de $(\mathrm{CH} 4)$ no biogás e das produções diária, volumétrica e específica de $\mathrm{CH}_{4}$ obtidos durante a operação do sistema em dois estágios, primeiro reator (r1) e segundo reator (r2), nos ensaios 1,2 e 3 .

Tabela 4.6 Estimativas das porcentagens da DQO $_{\text {total }}$ afluente e removida convertidas em metano $\left(\mathrm{CH}_{4}\right)$ e da relação entre a produção diária de $\left(\mathrm{CH}_{4}\right)$ medida (expressa em g DQO- $\left.\mathrm{CH}_{4} \cdot \mathrm{d}^{-1}\right)$ e a $\mathrm{DQO}_{\text {dissolvida }}$ removida, a partir das médias diárias de DQO afluente, efluente, removida e na forma de $\mathrm{CH}_{4}$ no primeiro e segundo reatores.

Tabela 4.7 Estimativas de balanço de massa no primeiro e segundo reatores, realizada de acordo com os procedimentos adotados por OLIVEIRA (1997) com base em SAYED (1987) e YANG \& CHOU (1985).

Tabela 4.8. Balanço de massa para determinação do fator de acumulação de lodo (Y acumulado) no primeiro e segundo reatores durante a operação do sistema em dois estágios, nos ensaios 1,2 e 3 .

Tabela 4.9. Valores médios e coeficiente de variação $(\mathrm{CV})$ das concentrações de nitrogênio total kjeldahl (NTK), nitrogênio amoniacal ( $\mathrm{N}_{\mathrm{am}}$.), nitrogênio orgânico $\left(\mathrm{N}_{\text {org. }}\right)$, no afluente e efluente, e eficiência de remoção (E) de 
NTK e $\mathrm{N}_{\text {org. }}$ obtidos durante a operação do sistema em dois estágios, primeiro (r1) e segundo $(\mathrm{r} 2)$ reatores, nos ensaios 1,2 e 3.

Tabela 4.10. Valores médios e coeficiente de variação $(\mathrm{CV})$ da concentração de fósforo total $\left(\mathrm{P}_{\text {total }}\right)$, no afluente e efluente, e eficiência de remoção $(\mathrm{E})$ obtidos durante a operação do sistema em dois estágios, primeiro (r1) e

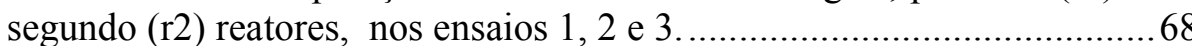

Tabela 4.11. Valores médios e o coeficiente de variação $(\mathrm{CV})$ do $\mathrm{pH}$, alcalinidade total (AT), parcial (AP) e intermediária (AI), concentração de ácidos voláteis totais (AVT) do afluente (a) e efluente do primeiro reator ( $\mathrm{r} 1)$, relações AI:AP e AVT:AT no efluente obtidos durante a operação do sistema em dois estágios nos ensaios 1,2 e 3........................................... 72

Tabela 4.12. Valores médios e coeficientes de variação (CV) dos ácidos voláteis: acético, propiônico, isobutírico, butírico, isovalérico, valérico e capróico, obtidos durante a operação do sistema em dois estágios nos ensaios 1,2 e 3

Tabela 4.13. Freqüência de microrganismos observada no inóculo, lodo de descarte e na manta de lodo do primeiro reator, nos ensaios 1,2 e 3 .

Tabela 4.14. Freqüência de microrganismos observada no inóculo, lodo de descarte e na manta de lodo do segundo reator, nos ensaios 1,2 e 3 


\section{LISTA DE ABREVIATURAS}

\begin{tabular}{|c|c|}
\hline AI & - Alcalinidade intermediária $\left(\mathrm{mg} \cdot \mathrm{L}^{-1}\right)$ \\
\hline AP & - Alcalinidade parcial (mg.L $\left.{ }^{-1}\right)$ \\
\hline AT & - Alcalinidade total $\left(\mathrm{mg} \cdot \mathrm{L}^{-1}\right)$ \\
\hline AVT & - Ácidos voláteis totais (mg. $\left.\mathrm{L}^{-1}\right)$ \\
\hline $\mathrm{CHV}$ & - Carga hidráulica volumétrica $\left[\mathrm{m}^{3} .\left(\mathrm{m}^{3} \text { reator.d }\right)^{-1}\right]$ \\
\hline CNTP & - Condições normais de temperatura e pressão $\left(1 \mathrm{~atm}, 0^{\circ} \mathrm{C}\right)$ \\
\hline $\mathrm{CV}$ & - Coeficiente de variação da média (\%) \\
\hline $\mathrm{DQO}_{\text {total }}$ & - Demanda química de oxigênio (mg.L $\left.\mathrm{L}^{-1}\right)$ \\
\hline $\mathrm{DQO}_{\text {dissolvida }}$ & - Demanda química de oxigênio da fração dissolvida $\left(m g . L^{-1}\right)$ \\
\hline $\mathrm{DQO}_{\mathrm{SS}}$ & $\begin{array}{l}\text { - Demanda química de oxigênio da fração devido à concentração } \\
\text { de sólidos suspensos }\left(\mathrm{mg} . \mathrm{L}^{-1}\right)\end{array}$ \\
\hline $\mathrm{DQO}_{\text {coloidal }}$ & - Demanda química de oxigênio devido à fração coloidal (mg.L $\left.\mathrm{L}^{-1}\right)$ \\
\hline EDX & - Microanálise de energia dispersiva de raio $\mathrm{x}$ \\
\hline MEV & - Microscopia eletrônica de varredura \\
\hline NTK & - Nitrogênio total kjeldahl (mg.L $\left.\mathrm{L}^{-1}\right)$ \\
\hline $\mathrm{N}_{\text {org. }}$ & - Nitrogênio orgânico (mg.L $\left.\mathrm{L}^{-1}\right)$ \\
\hline $\mathrm{N}_{\mathrm{am}}$ & - Nitrogênio (mg.L $\left.\mathrm{L}^{-1}\right)$ \\
\hline $\mathrm{pH}$ & - Potencial hidrogeniônico \\
\hline $\mathrm{P}_{\text {total }}$ & - Fósforo total (mg. $\left.\mathrm{L}^{-1}\right)$ \\
\hline $\mathrm{SF}$ & - Sólidos fixos (mg.L $\left.\mathrm{L}^{-1}\right)$ \\
\hline SSF & - Sólidos suspensos fixos (mg.L $\left.{ }^{-1}\right)$ \\
\hline SST & - Sólidos suspensos totais $\left(\mathrm{mg} . \mathrm{L}^{-1}\right)$ \\
\hline SSV & - Sólidos suspensos voláteis (mg. $\left.\mathrm{L}^{-1}\right)$ \\
\hline SS & - Sólidos suspensos \\
\hline $\mathrm{ST}$ & - Sólidos totais (mg.L $\left.{ }^{-1}, \%\right)$ \\
\hline SV & - Sólidos voláteis (mg. $\left.\mathrm{L}^{-1}\right)$ \\
\hline TCOV & - Taxa de carregamento orgânico volumétrico $\left(\mathrm{kg}\right.$ DQO. $\left.\mathrm{m}^{-3} \cdot \mathrm{d}^{-1}\right)$ \\
\hline TCL & - Taxa de carregamento no lodo [kg DQO.(kg SV.d) $\left.{ }^{-1}\right]$ \\
\hline $\mathrm{TDH}$ & - Tempo de detenção hidráulica (h) \\
\hline UASB & - Reator anaeróbio de fluxo ascendente com manta de lodo \\
\hline
\end{tabular}




\section{LISTA DE SÍMBOLOS}

$\begin{array}{ll}\mathrm{CaCO}_{3} & \text { - Calcita ou carbonato de cálcio } \\ \mathrm{CH}_{3} \mathrm{COOH} & - \text { Ácido acético } \\ \mathrm{CH}_{4} & - \text { Metano } \\ \mathrm{CO}_{2} & - \text { Gás carbônico ou dióxido de carbono } \\ \mathrm{E}(\%) & - \text { Eficiência } \\ \mathrm{M} & - \text { Molar } \\ \mathrm{NaOH} & - \text { Hidróxido de sódio } \\ \mathrm{Y} & - \text { Fator de acumulação de lodo no reator }\end{array}$




\section{RESUMO}

PEREIRA, E.R. (2004). Desempenho e caracterização microbiana do processo de dois estágios com reatores anaeróbios de fluxo ascendente com manta de lodo (uasb) tratando águas residuárias de suinocultura. 119p. Dissertação (Mestrado) - Escola de Engenharia de São Carlos, Universidade de São Paulo.

Foram operados dois reatores UASB de bancada (volumes de 39,0 e 10,5 L) instalados em série, alimentados com águas residuárias de suinocultura com concentração de sólidos suspensos totais (SST), no primeiro reator, em torno de 5000 mg. $\mathrm{L}^{-1}$, com temperatura controlada (de $25^{\circ}$ a $30^{\circ} \mathrm{C}$ ) e com tempo de detenção hidráulica (TDH) no primeiro reator de 62 a $16 \mathrm{~h}$ e no segundo de 16 a $4 \mathrm{~h}$. O objetivo foi avaliar o desempenho e caracterizar física e microbiologicamente o lodo dos reatores UASB operados em dois estágios. Os resultados obtidos no ensaio 1, com TDH de $62 \mathrm{~h}$ no primeiro reator e SST no afluente de $5240 \mathrm{mg} . \mathrm{L}^{-1}$, mostraram eficiências de remoção de $\mathrm{DQO}_{\text {total }}$ de $86 \%$ e $59 \%$ e SST de $82 \%$ e $57 \%$, no primeiro e segundo reatores, respectivamente. A eficiência de remoção de $\mathrm{DQO}_{\text {total }}$ e SST no sistema, no ensaio 1, foi de $95 \%$ e $94 \%$. No ensaio 2, com TDH de $31 \mathrm{~h}$ no primeiro reator e SST de $5000 \mathrm{mg} . \mathrm{L}^{-1}$ no afluente, observou-se eficiência de remoção de DQO $_{\text {total }}$ de $86 \%$ e $43 \%$ e SST de $85 \%$ e $58 \%$, no primeiro e segundo reatores, respectivamente. A eficiência de remoção de DQO $_{\text {total }}$ e SST no sistema, no ensaio 2 , foi de $92 \%$ e $94 \%$. No ensaio 3, com TDH de $16 \mathrm{~h}$ no primeiro reator e SST de $5490 \mathrm{mg}^{-\mathrm{L}^{-1}}$ no afluente, observou-se eficiência de remoção de $\mathrm{DQO}_{\text {total }}$ de $73 \%$ e $23 \%$ e SST de $65 \%$ e $20 \%$, no primeiro e segundo reatores, respectivamente. A eficiência de remoção de DQO $_{\text {total }}$ e SST no sistema, no ensaio 3 , foi de $79 \%$ e $73 \%$. A TCOV aplicada no primeiro reator, no ensaio 1 , foi de $4,55 \mathrm{~kg}$ DQO $_{\text {total }} \cdot \mathrm{m}^{-3} \cdot \mathrm{d}^{-1}$, no ensaio 2 de $8,75 \mathrm{~kg}$ DQO $_{\text {total }} \cdot \mathrm{m}^{-3} \cdot \mathrm{d}^{-1}$ e no ensaio 3 de 18,65 $\mathrm{kg} \mathrm{DQO}$ total. $\mathrm{m}^{-3} \cdot \mathrm{d}^{-1}$. A produção de $\mathrm{CH}_{4}$ no primeiro reator foi de 17,50 a $68,20 \mathrm{~L} \mathrm{CH}_{4} \mathrm{~d}^{-}$ ${ }^{1}$ e no segundo reator de 1,62 a $5,50 \mathrm{~L} \mathrm{CH}_{4} \mathrm{~d}^{-1}$ com a diminuição do TDH. Os reatores UASB instalados em série foram eficientes na remoção da fração dissolvida e, principalmente, da fração devido à concentração de SST do afluente. Para TCOV de $4,55 \mathrm{~kg}$ DQO. $\mathrm{m}^{-3} \cdot \mathrm{d}^{-1}$ no primeiro reator, pôde-se obter eficiências de remoção de DQO $_{\text {total }}$ e de SST acima de $90 \%$ e de DQO dissolvida acima de $85 \%$. Para TCOV de 18,65 $\mathrm{kg}$ DQO. $\mathrm{m}^{-3} \cdot \mathrm{d}^{-1}$ no primeiro reator, as eficiências de remoção de $\mathrm{DQO}_{\text {total }}$ e de SST foram acima de $70 \%$ e $\mathrm{DQO}_{\text {dissolvida }}$ acima de $75 \%$. As maiores produções específicas de metano foram obtidas com TCOV de $2,55 \mathrm{~kg}$ DQO. $\mathrm{m}^{-3} \cdot \mathrm{d}^{-1}$ para o segundo reator e de $8,65 \mathrm{~kg} \mathrm{DQO} \cdot \mathrm{m}^{-3} \cdot \mathrm{d}^{-1}$ para o primeiro reator. A operação dos reatores UASB com valores de concentração de SST no afluente em torno de $5000 \mathrm{mg} . \mathrm{L}^{-1}$ foram prejudiciais ao processo de granulação do lodo. Os grânulos apresentaram distribuição dispersa das morfologias microbianas ao longo da parede, não caracterizando a divisão em camadas definidas. As arqueas metanogênicas predominantes foram as semelhantes à Methanosaeta.

PALAVRAS-CHAVE: digestão anaeróbia, reatores anaeróbios de dois estágios, arqueas metanogênicas, resíduos de suínos. 


\section{ABSTRACT}

PEREIRA, E.R. (2004). Performance and microbial characterization of the two stage process with upflow anaerobic sludge blanket reactors (UASB) treating swine wastewater. 119p. Dissertação (Mestrado) - Escola de Engenharia de São Carlos, Universidade de São Paulo.

Two bench scale UASB reactors (volumes of 39,0 and 10,5 L) were operated in sequence, fed with swine wastewater with total suspended solids (TSS) concentration around $5000 \mathrm{mg} . \mathrm{L}^{-1}$ in the first reactor, with controlled temperature (from $25^{\circ}$ to $30^{\circ} \mathrm{C}$ ) and operating with hydraulic detention time (HDT) in the first reactor varying from 62 to $16 \mathrm{~h}$ and in the second reactor from 16 to $4 \mathrm{~h}$. The objective was to evaluate the performance and to characterize physically and microbiologically the sludge from UASB reactors operated in two stages treating swine wastewater. The results obtained in phase 1, with HDT of $62 \mathrm{~h}$ in the first reactor and TSS in the influent of $5240 \mathrm{mg} . \mathrm{L}^{-1}$, presented total COD removal efficiencies of $86 \%$ and $59 \%$ and TSS reduction efficiency of $82 \%$ and $57 \%$, in the first and second reactors, respectively. The removal efficiency of ${ }_{\text {total }}$ COD and TSS in the system, in phase 1 , was $95 \%$ and $94 \%$, respectively. In the phase 2, using HDT of $31 \mathrm{~h}$ in the first reactor and TSS of $5000 \mathrm{mg} . \mathrm{L}^{-1}$ in the influent, it was observed a total COD removal efficiency of $86 \%$ and $43 \%$ and TSS reduction efficiency of $85 \%$ and $58 \%$, in the first and second reactors, respectively. The system removal efficiency of total COD and TSS in phase 2, was $92 \%$ and $94 \%$, respectively. In phase 3, with a HDT of $16 \mathrm{~h}$ in the first reactor and TSS of $5490 \mathrm{mg} . \mathrm{L}^{-1}$ in the influent, it was observed a total COD removal efficiency of $73 \%$ and $23 \%$ and TSS reduction efficiency of $65 \%$ and $20 \%$, in the first and second reactors, respectively. The total COD removal efficiency and TSS reduction efficiency in the system, in phase 3, was $79 \%$ and $73 \%$, respectively. The volumetric organic loading rate (VOLR) applied in the first reactor, in phase 1 , was $4,55 \mathrm{~kg}$ total COD. $\mathrm{m}^{-3} \cdot \mathrm{d}^{-1}$, in phase 2 was $8,75 \mathrm{~kg}$ total COD. $\mathrm{m}^{-3} \cdot \mathrm{d}^{-1}$ and in phase 3 was $18,65 \mathrm{~kg}$ total $C O D \cdot \mathrm{m}^{-3} \cdot \mathrm{d}^{-1}$. The $\mathrm{CH}_{4}$ production in the first reactor was from 17,50 to $68,20 \mathrm{~L} \mathrm{CH}_{4} \mathrm{~d}^{-1}$ and in the second reactor from 1,62 to 5,50 $\mathrm{L} \mathrm{CH}_{4} \mathrm{~d}^{-}$ ${ }^{1}$ decreasing the HDT in the experiment phases. The UASB reactor installed in sequence were efficient in the dissolved fraction removal and, mainly, to the fraction due to the TSS influent concentration. The total VOL value of $4,55 \mathrm{~kg} \mathrm{CDO} \cdot \mathrm{m}^{-3} \cdot \mathrm{d}^{-1}$ was measured in the first reactor, it was achieved TSS and total CDO removal efficiencies above $90 \%$ and dissolved COD above $85 \%$. For the OVL of $18,65 \mathrm{~kg} \mathrm{CDO} \cdot \mathrm{m}^{-3} \cdot \mathrm{d}^{-1}$ in the first reactor the TSS and total COD removal were above $70 \%$ and dissolved COD above $75 \%$. The larger methane specific production was obtained with a total VOL of $2,55 \mathrm{~kg}$ CDO. $\mathrm{m}^{-3} \cdot \mathrm{d}^{-1}$ in the second reactor and $8.65 \mathrm{~kg} \mathrm{CDO} \cdot \mathrm{m}^{-3} \cdot \mathrm{d}^{-1}$ in the first reactor. The UASB reactors operation with the TSS concentration values pf $5000 \mathrm{mg} . \mathrm{L}^{-1}$ in the influent was prejudicing the sludge granulation process. The granules present a microbial morphology disperse distribution that doesn't characterize a layers defined distribution. The predominant Metonogenic Archeas were similar to Methanosaeta.

KEY-WORD: anaerobic digestion, two stage anaerobic reactor, methanogenic arqueas, swine wastewater. 


\section{INTRODUÇÃO}

A aplicação da biotecnologia anaeróbia, utilizando reatores anaeróbios de alta taxa, encontra-se praticamente consolidada para tratamento de determinadas águas residuárias, principalmente orgânicas. Têm-se várias configurações de reatores estudadas com parâmetros e modelos para projeto claramente definidos, com experiências bem sucedidas em escala de bancada, piloto e real; o conhecimento da bioquímica e microbiologia, principalmente da metanogênese, com grandes avanços recentes; muitos estudos com biofilmes e grânulos; o conhecimento do controle de reatores propiciando operação segura, com resultados de desempenho satisfatórios; o pós-tratamento dos efluentes sendo estudado. Além destes, outros temas relacionados têm despertado interesse e trabalhos de pesquisa recentes, visando ampliar o conhecimento e a aplicabilidade dos processos anaeróbios para tratamento de resíduos.

As limitações relacionadas à hidrólise dos sólidos nos reatores anaeróbios de alta taxa, como por exemplo, no reator anaeróbio de fluxo ascendente com manta de lodo (UASB), são aspectos que se superado possibilitaria, principalmente, o tratamento de águas residuárias do setor agroindustrial e da agropecuária em grande escala, o esgoto sanitário bruto, o lodo de decantador secundário em sistemas de lodos ativados, entre outras, que apresentam altas concentrações de sólidos suspensos. A avaliação do desempenho aplicando-se o estudo de configurações inovadoras de reatores anaeróbios, como o processo em dois estágios com reatores UASB aliado a avaliação das populações microbianas participantes do processo, podem propiciar conhecimentos que permitam ampliar o entendimento e a aplicação dos processos anaeróbios.

As águas residuárias de suinocultura apresentam altas concentrações de sólidos suspensos e provocam impactos ambientais acentuados em várias regiões no Brasil e em outros países. Para o seu tratamento requerem uma alternativa tecnológica simplificada, robusta, versátil e de baixo custo, características que têm sido verificadas com a aplicação do processo UASB. 
Portanto, pesquisas com os reatores UASB em dois estágios tratando águas residuárias de suinocultura associam objetivos científicos e tecnológicos na área de processos anaeróbios, atendendo a problemas graves de poluição com necessidade de solução a curto prazo.

Desta forma, pretende-se com a operação de dois reatores UASB de bancada instalados em série e alimentados com águas residuárias de suinocultura:

- verificar o efeito do afluente, com concentração de sólidos suspensos totais (SST) em torno de $5000 \mathrm{mg} . \mathrm{L}^{-1}$, no desempenho dos reatores UASB operados em dois estágios e sob diferentes taxas de carregamento orgânico volumétrico (TCOV) e TDH;

- verificar o comportamento da manta de lodo dos reatores UASB operados em dois estágios, a partir das suas características físicas e microbiológicas, tais como crescimento da manta e distribuição de populações microbianas;

- sugerir valores de taxas de carregamento orgânico volumétrico (TCOV) e tempo de detenção hidráulica (TDH) para o projeto e operação de reatores UASB em dois estágios tratando águas residuárias de suinocultura, nas condições estudadas. 


\section{REVISÃO DA LITERATURA}

\subsection{Processo anaeróbio para tratamento de águas residuárias}

A digestão anaeróbia pode ser considerada como uma das tecnologias mais antigas para a estabilização de resíduos e águas residuárias. A necessidade de sistemas de tratamento de águas residuárias viáveis para a indústria alimentícia, na década de 70 , estimulou as maiores realizações da pesquisa na área de digestão anaeróbia. Os modernos reatores anaeróbios de alta taxa, nos quais o tempo de detenção hidráulica está dissociado do tempo de retenção dos sólidos, permitiram a ampla aceitação mundial da tecnologia anaeróbia como alternativa viável para sistemas de tratamento de águas residuárias (VAN LIER et al., 2001).

A seqüência de reações do processo anaeróbio sugere sua divisão em etapas: hidrólise, acidogênese, acetogênese e metanogênese. Entre os microrganismos existem interações tão estreitas que a atividade do metabolismo metanogênico influi sobre os produtos da hidrólise e fermentação. A eficiência global de conversão da matéria orgânica depende da eficiência de cada reação e do equilíbrio entre as diversas espécies de microrganismos presentes. A velocidade de cada reação influi na velocidade do processo e as reações mais lentas, denominadas etapas limitantes, irão determinar a velocidade da reação global (PAVLOSTATHIS e GIRALDO-GOMEZ, 1991).

\subsection{Características microbiológicas do processo anaeróbio}

Muitas teorias relacionadas com o início da formação de grânulos têm sido propostas. De acordo com Schmidt e Ahring (1996), vários pesquisadores têm sugerido que células filamentosas de Methanosaeta $s p$. são precursoras de grânulos. Esses filamentos podem funcionar como centros de nucleação para posterior desenvolvimento dos agregados. Outros pesquisadores têm sugerido que durante o início do processo de granulação, Methanosaeta sp. coloniza a cavidade central de aglomerados de Methanosarcina sp. Isso está baseado na 
observação de grânulos pequenos e presumivelmente jovens que apresentam Methanosaeta $s p$. no centro (SCHMIDT e AHRING, 1996).

Mcleod et al. (1990), estudando a estrutura de agregados bacterianos, os quais apresentavam três camadas bem características, sugeriram que a presença de células de Methanosaeta no núcleo central dos grânulos indicavam que estes microrganismos poderiam funcionar como "centros de nucleação" ou "motores" que iniciariam o desenvolvimento do grânulo. Uma série de filamentos soltos de Methanosaeta, desenvolvidos em culturas puras, proporcionou excelente estrutura colonizada por uma série de organismos de outras espécies.

Guiot et al. (1991), observando grânulos provenientes de reator mesofílico alimentado com sacarose, observou estrutura dividida em três camadas, cada uma possuindo diferentes morfologias microbianas características. Por meio da microscopia eletrônica, observou que as associações microbianas estavam encaixadas entre uma camada externa composta de populações heterogêneas, predominantemente de bactérias acidogênicas produtoras de hidrogênio, e também microrganismos utilizadores de hidrogênio como Methanosarcina, Methanococcus, Methanobrevibacter, Syntrophobacter e Methanospirillum, e um núcleo acetoclástico composto, quase que exclusivamente, de organismos semelhantes à Methanosaeta. O arranjo populacional proposto pelo autor está ilustrado na Figura 2.1.

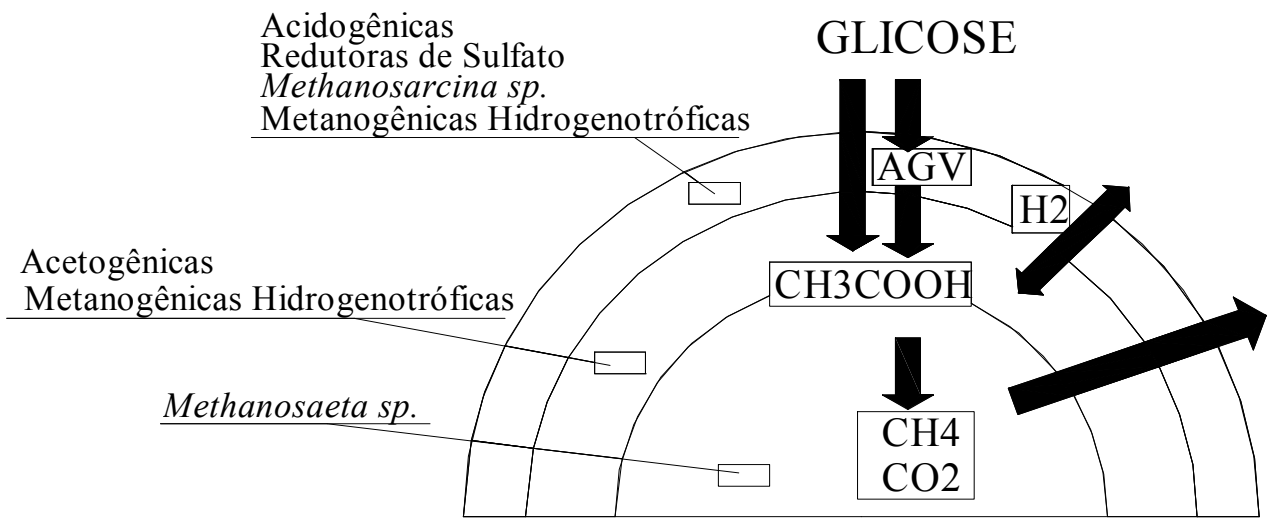

Figura 2.1 Arranjo populacional do grânulo

Fonte: Guiot (1991) 
Segundo Guiot et al. (1991) este modelo de estrutura estratificada e sua composição biológica já tinha sido reportado para grânulos alimentados com águas residuárias industriais como usinas de açúcar e amido de milho, para grânulos mesofílicos alimentados com mistura de ácidos graxos voláteis e grânulos termofílicos com acetato como substrato.

Banik et al. (1997) compararam o desenvolvimento de grânulos a temperaturas de 5, 15 e $25^{\circ} \mathrm{C}$ com objetivo de elucidar e comparar a composição e as características de três tipos de lodos granulares, tendo a mesma origem e tratando os mesmos resíduos orgânicos em três reatores sob diferentes condições de temperatura e carga. A alimentação dos reatores foi feita com resíduo sintético de leite desnatado e adicionados bicarbonato de sódio e metais traço. Os três reatores foram operados com TDH de 24 e 12 h, 16 e 8 h e 12 e 6 h, respectivamente. $O$ tamanho dos grânulos crescidos a $5^{\circ} \mathrm{C}$ foi de aproximadamente 1,8 a 2,8 mm, com superfície de composição microbiana complexa com algumas cavidades, possivelmente resultantes da produção de gás. As arqueas metanogênicas da camada externa eram de diversas morfologias, incluindo cocos, bacilos e alguns filamentos. O interior dos grânulos era densamente aglomerado com bactérias de várias morfologias e o centro frouxamente aglomerado com dois tipos de estrutura celular típica de Methanosaeta.

Os grânulos crescidos a $15^{\circ} \mathrm{C}$, com TDH de 16 e $8 \mathrm{~h}$, eram de forma irregular e os desenvolvidos a taxas de carga mais altas eram ligeiramente maiores. Não havia diferença significativa entre o interior e o exterior do grânulo. O tamanho dos grânulos crescidos a $25^{\circ} \mathrm{C}$ era de aproximadamente 1,5 a 2,5 mm, sem exibir estrutura em camadas. A parte mais externa era compreendida predominantemente de cocos, alguns bacilos e filamentos. Os exames em microscópio eletrônico de transmissão mostraram que os grânulos não tinham larga variedade de espécies e eram predominantemente compostos por amontoados frouxos de células semelhantes a Methanosaeta, material inorgânico e polímeros extracelulares (BANIK et al., 1997).

Os grânulos crescidos a $5^{\circ} \mathrm{C}$ tinham maior diversidade de espécies no seu interior, possivelmente indicando a existência de uma estrutura em camadas. Os autores também observaram que os grânulos, em todas as temperaturas, consistiam predominantemente de microrganismos semelhantes a Methanosaeta e sugeriram que a mesma exerce um papel central na granulação e retenção do lodo em processos anaeróbios de alta taxa.

Oliveira (1997) estudando grânulos, com forma esférica irregular, de reatores UASB tratando águas residuárias de suinocultura, por meio de microscopia eletrônica de varredura, observou que a distribuição das morfologias microbianas apresentaram-se de forma estruturada ao longo da parede e dividida em três camadas. Na camada superficial 
predominaram populações mistas constituídas de bactérias formando filamentos longos e finos, normalmente associadas às formadoras de ácidos e às hidrolíticas. Observaram-se bacilos retos com as extremidades retas, morfologia esta associada às arqueas metanogênicas e semelhantes à Methanosaeta sp., cuja predominância, aumentou a partir das camadas medianas. Na camada adjacente ao centro e no centro do grânulo predominaram microrganismos semelhantes à Methanosaeta.

Sekiguchi et al. (1999) aplicaram a metodologia de Hibridação Fluorescente in situ (FISH), com sondas de oligonucleotídeos com RNAr 16S, no estudo da distribuição espacial dos microrganismos no lodo de reatores UASB, em condições mesofílica e termofílica, alimentados com sacarose, acetato e propionato. Com o microscópio confocal a laser verificaram o arranjo dos microrganismos na forma de biofilme esférico, no qual observaramse a presença predominante de metanogênicas acetoclásticas, semelhantes à Methanosaeta sp., na camada interna e células semelhantes a Syntrophobacter e Desulfobulbus na camada externa.

A formação de grânulos divididos em três camadas deve-se, provavelmente, à composição predominantemente orgânica das águas residuárias de suinocultura, estimando a composição dos SSV em: 35\% de polissacarídeos complexos, 20\% de proteínas brutas, 15\% de lipídeos e 5\% de lignina, além de glicose, xilose e arabinose correspondendo a, aproximadamente, $90 \%$ dos açucares totais (IANOTTI ${ }^{1}$ et al.,1979 apud OLIVEIRA, 1997).

Samson et al. (1990) citaram que em águas residuárias contendo açúcares e altos teores de ácidos voláteis o desenvolvimento do lodo granular é mais rápido. Enquanto que composições com elevadas frações de sólidos em suspensão ou materiais refratários podem não desenvolver grânulos.

Vanderhaegen et al. (1991) realizaram estudos em escala de laboratório com reatores UASB de 2,0 litros usando substrato com diferente conteúdo energético; ou seja, glicose, metanol, etanol, ácido propiônico e ácido acético. Testaram também diferentes substratos: vinhaça fresca e vinhaça pré acidificada durante dois dias. Os testes mostraram melhor produção de lodo granular com a vinhaça fresca. Esse aspecto sugeriu que para atingir o crescimento do lodo granular nos reatores UASB, o substrato deve conter quantidade substancial de açúcares fermentáveis para que as bactérias acidogênicas, presentes no grânulo, recebam suficiente quantidade destes substratos de alta energia. Em uma série de testes adicionais, os autores também estudaram o efeito de altos níveis de proteínas, o qual resultou

\footnotetext{
${ }^{1}$ IANNOTTI, E.L. et al. (1979). Changes in swine waste during anaerobic digestion. Developments in
} Industrial Microbiology, v.20, n.49, p.519-529. 
em deterioração da qualidade do lodo produzido e em redução considerável da produção de lodo granular.

Os resultados obtidos por Vanderhaegen et al. (1991), suportam o conceito do grânulo composto de múltiplas camadas como proposto por Mcleod (1990). No entanto, os autores postularam a teoria que as bactérias acidogênicas fermentadoras de açúcares formam biomassa e polímeros suficientes para atuar como "centros de nucleação", nos quais subseqüentemente, o restante das associações metanogênicas chega a se desenvolver.

\subsection{Reator anaeróbio de fluxo ascendente com manta de lodo (UASB)}

A digestão anaeróbia utilizando reatores UASB tem potencial de aplicação para muitos resíduos. Além disso, os reatores UASB oferecem muitas vantagens, tais como: taxas de carregamento maiores que aquelas admitidas pelos sistemas de mistura completa, implicando em volumes necessários de reator bem menores; não necessita de mistura artificial, uma operação difícil e dispendiosa; e não necessita de tanque de sedimentação (LETTINGA et al., 1980).

A utilização de reatores UASB para tratar, principalmente, águas residuárias solúveis tem sido suficientemente demonstrada, tanto em escala piloto quanto em escala real. Diante disto, vários pesquisadores têm destacado a necessidade de trabalhos com reatores UASB para tratamento de águas residuárias complexas, inclusive no que diz respeito ao conteúdo de sólidos suspensos, os quais prejudicam o desenvolvimento e manutenção das características granulares do lodo. Assim como outras configurações de reatores anaeróbios, o reator UASB também está sujeito a limitações relacionadas à concentração de sólidos suspensos totais (SST) do afluente, as quais variam de 500 a $1000 \mathrm{mg} . \mathrm{L}^{-1}$. Posteriormente, foram apresentadas recomendações de 6000 a 8000 mg. $\mathrm{L}^{-1}$ de SST (LETTINGA et al., 1980, LETTINGA e HULSHOFF-POL, 1991, LETTINGA, 1996).

Nestas condições, o processo metanogênico é limitado pela taxa de hidrólise dos sólidos orgânicos. Isto tem maior importância no tratamento anaeróbio de resíduos sólidos, estercos, lodos e águas residuárias com altas concentrações de sólidos suspensos, tais como o esgoto sanitário bruto (VAN LIER et al., 2001) e as águas residuárias de suinocultura (OLIVEIRA, 1997).

Para isso, podem ser esperados avanços no campo da utilização de sistemas de leito de lodo (UASB e outros) em estágios para o tratamento de águas residuárias específicas (VAN LIER et al., 2001). Assim, para tratar água residuária com alta participação de fração 
orgânica particulada pode ser vantajoso aplicar-se o processo anaeróbio em dois estágios (SEGHEZZO et al., 1998).

\subsection{Processo anaeróbio em dois estágios}

No tratamento de águas residuárias com elevada concentração de sólidos suspensos (SST), como esgoto sanitário bruto e águas residuárias de suinocultura, em reatores UASB, a principal restrição são os altos arrastes de sólidos suspensos e a baixa taxa de hidrólise em condições de baixas temperaturas. O incremento da hidrólise do material orgânico complexo é fundamental, por ser o passo limitante, para estes e outros substratos como os resíduos sólidos, semi-sólidos, lodos e dejetos da produção animal (OLIVEIRA, 1997, VAN LIER et al., 2001).

A retenção dos sólidos suspensos no reator conduzirá a maiores tempos de retenção do lodo, propiciará aumentos na eficiência do tratamento e diminuirá a quantidade de sólidos no efluente, minimizando as necessidades de pós-tratamento. Assim, a otimização da configuração dos reatores poderá envolver o processo em estágios separados em tanques, para propiciar condições ótimas para os grupos específicos de microrganismos envolvidos nas etapas desejadas (VAN LIER et al., 2001).

O processo anaeróbio de dois estágios, segundo Van Haandel e Lettinga (1994), consiste em dois reatores em série, um para hidrólise parcial da matéria orgânica particulada e o outro para digerir os compostos solúveis formados no primeiro reator. $\mathrm{O}$ primeiro reator hidrolítico, com velocidade ascensional relativamente baixa, conterá lodo floculento. A matéria orgânica particulada do afluente poderá ser adsorvida e parcialmente hidrolisada nos flocos e reintroduzida como compostos solúveis na fase líquida, os quais serão tratados no segundo reator. A eficiência de remoção de sólidos suspensos no primeiro reator será maior do que a remoção da matéria orgânica solúvel e será necessário a descarga periódica do excesso de lodo (SEGHEZZO et al., 1998).

Sayed et al. (1993) pesquisaram o tratamento anaeróbio em dois estágios para águas residuárias de abatedouro, contendo $55 \%$ da DQO devido à fração de SST grosseiros insolúveis. Utilizaram reator UASB de bancada com lodo floculento seguido de reator UASB com lodo granulado, à temperatura de $18^{\circ} \mathrm{C}$, com TCOV de 5,10 e $15 \mathrm{~kg}$ DQO.m $\mathrm{m}^{-3} \cdot \mathrm{d}^{-1}$ e com $\mathrm{TDH}$ no primeiro reator de 12,8 e $4 \mathrm{~h}$ e no segundo de 4,2; 2,1 e 1,4 h. Os resultados indicaram que no primeiro reator foi possível remover satisfatoriamente a DQO devido às frações de SST grosseiros e coloidais, com eficiência em torno de $70 \%$, porém para a 
$\mathrm{DQO}_{\text {solúvel }}$ a remoção foi moderada, ou seja, de $55 \%$. No segundo reator foi observado bom desempenho na remoção das três frações, sendo 80,80 e $90 \%$, respectivamente. Isto foi atribuído à baixa concentração das frações de SST grosseiros e coloidal na alimentação do segundo reator, as quais foram removidas no primeiro reator, prevalecendo mecanismos não biológicos de entrelaçamento e adsorção. Para todo o sistema a eficiência de remoção atingiu 90\% para $\mathrm{DQO}_{\text {total }}, 95 \%$ para DQO devido à fração de SST grosseiros, 80\% para $\mathrm{DQO}_{\text {coloidal }} \mathrm{e}$ $80 \%$ para $\mathrm{DQO}_{\text {solúvel. }}$

Sayed e Fergala (1995) utilizando o processo em dois estágios com reatores UASB (o primeiro com lodo floculento e o segundo com lodo granulado), para tratamento de esgoto sanitário bruto $\left(\mathrm{DQO}_{\text {total }}\right.$ de 200 a $700 \mathrm{mg} . \mathrm{L}^{-1}$ com $55 \%$ correspondendo à $\mathrm{DQO}_{\mathrm{ss}}$ ), com temperatura de $18^{\circ}$ a $20^{\circ} \mathrm{C}$, verificaram eficiências de remoção de $\mathrm{DBO}_{\text {total }}$ e DQO $\mathrm{D}_{\text {total }}$ de 90 e $80 \%$, respectivamente, com TCOV de 2 e $6 \mathrm{~kg}$ DQO. $\mathrm{m}^{-3} \cdot \mathrm{d}^{-1}$, no primeiro e segundo reatores, respectivamente.

Observa-se que a proposta de aplicação de sistemas em dois estágios é recente, e não significa o mesmo que sistemas em duas fases. Existe alguma controvérsia a respeito das vantagens da instalação de reator acidogênico separado para a eficiência global do processo. Embora certa pré-acidificação da água residuária seja, certamente, benéfica, existem evidências claras de que a acidificação completa, proposta nos sistemas em duas fases, pode ser prejudicial em alguns aspectos (LETTINGA e HULSHOFF-POL, 1991, SEGHEZZO et al., 1998).

\subsection{Características dos dejetos de suínos}

A adoção de sistemas confinados de produção de suínos, com uso intensivo de água para higienização, tem produzido grandes quantidades de dejetos líquidos e semi-sólidos. A inadequação dos sistemas de manejo e armazenamento destes dejetos induzem o seu lançamento em cursos d'água sem tratamento, causando graves problemas de poluição, no Brasil e outros países, em virtude das altas concentrações de matéria orgânica, nutrientes, metais pesados e patógenos. No Estado de Santa Catarina, 85\% das fontes de água do meio rural das regiões produtoras estão poluídas e/ou contaminadas por coliformes fecais. Estes problemas são relatados, em menor proporção, no Paraná, São Paulo e Minas Gerais (OLIVEIRA et al., 1993, OLIVEIRA, 1997).

Zhu et al. (2000) examinaram as populações de microrganismos nas fezes de suínos observando: 39\% para cocos Gram-positivos, 27\% de Eubacterium sp., 20\% de Lactobacillus 
sp., 8\% de Escherichia Gram-negativa, 4\% de Clostridium sp. e menos de 2\% de Propionibacterium acnes e Bacteroides. Entre estas populações, as bactérias anaeróbias e facultativas predominaram.

Em 2002, o rebanho brasileiro de suínos foi estimado em 38 milhões de cabeças (IBGE, 2002), distribuídos pelo país, conforme relacionado na Tabela 2.1.

Tabela 2.1 Rebanho de suínos por região geográfica do Brasil

\begin{tabular}{lccl}
\hline Região & \multicolumn{2}{c}{$\mathbf{N}^{\mathbf{0}}$ Cabeças } & \multicolumn{1}{c}{ Estados } \\
& (milhões) & $\mathbf{( \% )}$ & \\
\hline \hline Sul & 13,00 & 34,21 & RS, SC, PR. \\
Sudeste & 7,20 & 18,95 & MG, ES, RJ, SP. \\
Nordeste & 8,75 & 23,03 & MA, PI, CE, RN, PB, AL, SE, BA, PE. \\
Centro & 6,15 & 16,18 & MT, MS, GO, DF. \\
Norte & 2,90 & 7,63 & RO, AC, AM, RR, PA, AP, TO. \\
\hline TOTAL & $\mathbf{3 8 , 0 0}$ & $\mathbf{1 0 0 , 0 0}$ & \\
\hline
\end{tabular}

Fonte: (IBGE, 2002), adaptado de ABCS (2004).

Os dejetos de suínos são constituídos por fezes, urina, água dos bebedouros e resíduos de alimentos. O volume total de dejetos de uma criação depende, ainda do sistema de manejo adotado, bem como do volume de água utilizado na higienização das baias. Montalvo (1995) citou valores de uso de água para limpeza de instalações de suínos variando de 6 a $50 \mathrm{~L} \mathrm{~d}^{-1}$ por animal. Dependendo da freqüência de lavagem das baias, o teor de resíduos sólidos nos dejetos de suínos pode variar. Holmberg et al. (1983) e Kalyuzhnyi et al. (2000) citaram concentrações de sólidos, nas águas residuárias de suinocultura, de 0,5 a 4,0\%. No Brasil, Oliveira et al. (1995) citaram concentrações de ST de $26885 \mathrm{mg} . \mathrm{L}^{-1}$ e SST de $14610 \mathrm{mg} . \mathrm{L}^{-1}$ e Oliveira et al. (2000) citaram concentrações de ST de $2400 \mathrm{mg} . \mathrm{L}^{-1}$, em águas residuárias de suinocultura.

A recomendação para a utilização e tratamento sustentável destes dejetos é a separação mecânica preliminar das frações sólida e líquida e o tratamento biotecnológico da fração líquida em processos secundários, tais como, os anaeróbios de alta taxa (MONTALVO, 1995, KALYUZHNYI et al., 2000); ou a aplicação do tratamento anaeróbio diretamente aos dejetos líquidos brutos.

Holmberg et al. (1983) utilizaram peneiras vibratórias (malha de 0,01 a 0,25 cm), para dejetos de suínos com ST de 1,5 a 5,4\%, e verificaram a retenção nas peneiras de $41 \%$ dos 
sólidos voláteis, $37 \%$ da DQO e $41 \%$ do carbono total. Dos compostos inorgânicos, $91 \%$ do $\mathrm{N}_{\mathrm{am}}$. e $75 \%$ do $\mathrm{P}_{\text {total }}$ permaneceram na fração líquida.

Kalyuzhnyi et al. (2000) utilizaram filtro com palha de trigo para separação sólidolíquido de dejetos de suínos com SST de $30000 \mathrm{mg} . \mathrm{L}^{-1}, \mathrm{~N}_{\text {total }}$ de $2000 \mathrm{mg} . \mathrm{L}^{-1}$ e $\mathrm{P}_{\text {total }}$ de 500 mg. $\mathrm{L}^{-1}$ e obtiveram, com $4 \mathrm{~h}$ de operação e com ciclo de $4 \mathrm{~d}$, eficiências de remoção de SST, $\mathrm{N}_{\text {total }}$ e $\mathrm{P}_{\text {total }}$, de 97,45 e 75\% e 65, 27 e 32\%, respectivamente. Ensaiaram o filtro com dejetos mais diluídos $\left(\mathrm{DQO}_{\text {total }}\right.$ de 8300 a $10000 \mathrm{mg} . \mathrm{L}^{-1}, \mathrm{DQO}_{\mathrm{ss}}$ de 1800 a $2100 \mathrm{mg} . \mathrm{L}^{-1}$ e $\mathrm{DQO}_{\text {coloidal }}$ de 1900 a $4200 \mathrm{mg} . \mathrm{L}^{-1}$ ) e observaram eficiências de remoção de 15 a $17 \%$, 38 a $67 \%$ e 58 a $64 \%$, respectivamente.

No Brasil, Oliveira et al. (1995) observaram que, respectivamente, os ST e SST de 26885 e $14610 \mathrm{mg} . \mathrm{L}^{-1}$ das águas residuárias de suinocultura, diminuíram para 13400 e 1640 mg. $\mathrm{L}^{-1}$ após uma peneira vibratória e para 6770 e $1430 \mathrm{mg} . \mathrm{L}^{-1}$ após o sedimentador instalado em série. A instalação do tanque de equalização aumentou a eficiência de remoção de SST da peneira de 47 para $89 \%$.

Brandão et al. (2000) utilizaram filtros preenchidos com bagaço de cana, casca de arroz, casca de café, sabugo de milho, serragem de madeira e carvão vegetal, para afluente com ST de 5500 mg. $\mathrm{L}^{-1}$ e sólidos sedimentáveis (Ssed) de 88,25 mL.L $\mathrm{L}^{-1}$. Verificaram eficiência de remoção máxima de 33\% para os ST, com o fino de carvão vegetal, e superior a $90 \%$ para os Ssed, em todos materiais filtrantes.

\subsection{Tratamento de águas residuárias de suinocultura em reatores UASB}

O tratamento dos dejetos de suínos é um desafio mundial. Diante dos impactos ambientais provocados pela atividade, países como Holanda e Alemanha deixaram de produzir suínos e, no Brasil, algumas granjas já foram fechadas e outras estão ameaçadas. Estas medidas comprometem o setor suinícola, inibindo novos investimentos. Não há processo único capaz de tratar os dejetos de suínos com a facilidade que se deseja. A disposição dos dejetos, na forma bruta, ao solo é o tratamento mais difundido, porém têm encontrado sérias limitações econômicas e ambientais (JÚNIOR, 1999). Oliveira et al. (2000) concluíram que o aumento da concentração de ST (2400; 7000; 16300 e 26900 mg.L $\left.\mathrm{L}^{-1}\right)$ dos dejetos de suínos provocaram redução na capacidade de infiltração do solo e que as aplicações sucessivas ocasionaram selamento superficial. 
Na Tabela 2.2 estão apresentados os resultados de trabalhos com resíduos diluídos de suinocultura, tratados em reatores anaeróbios não convencionais.

O tratamento anaeróbio das águas residuárias de suinocultura, com concentrações de sólidos de 250 a $3500 \mathrm{mg} . \mathrm{L}^{-1}$, utilizando-se os reatores anaeróbios de alta taxa foi intensivamente revisado por Oliveira (1997). Pôde-se evidenciar que o tratamento com remoções de DQO próximas a $80 \%$, com o afluente com SST ao redor de $5000 \mathrm{mg} . \mathrm{L}^{-1}$, foi obtido com o reator anaeróbio de leito expandido, com TDH de 24 a 48 h (NG \& CHIN, 1988). Para ST ao redor de $10000 \mathrm{mg} . \mathrm{L}^{-1}$ o melhor desempenho foi verificado nos filtros anaeróbios, com TDH de 40 a 72 h (OLESZKIEWICZ, 1983). Para ST de 15000 a 20000 $\mathrm{mg} . \mathrm{L}^{-1}$, o reator anaeróbio de mistura completa com crescimento da biomassa aderida às partículas em suspensão (COBB \& HILL, 1989), apresentou os melhores resultados.

A faixa de 480 a $3500 \mathrm{mg} . \mathrm{L}^{-1}$ de SST do afluente foi abrangida no trabalho de Hasheider e Sievers (1984) com filtro anaeróbio, cujas melhores remoções médias máximas de DQO e ST foram, respectivamente, 86 e 74\%. Yang e Chou (1985), com o reator anaeróbio de chicanas, utilizaram afluente na faixa de 250 a $1450 \mathrm{mg} . \mathrm{L}^{-1}$ de SST obtendo eficiências médias de remoção de DQO de 81,2\%, com TDH de 19 h. Com TDH de 32 h obtiveram remoção de SST de $88,2 \%$.

$\mathrm{Ng}$ e Chin (1988) destacaram que com exceção do reator de chicanas, as outras configurações de reatores anaeróbios estudadas até aquela data para tratamento de águas residuárias de suinocultura poderiam requerer nível de operação, a qual não estaria prontamente disponível nas propriedades rurais. Além disso, os custos de construção poderiam ser altos e isto seria uma das desvantagens dos filtros anaeróbios, associado aos cuidados necessários para evitar entupimentos. 
Tabela 2.2 Reatores anaeróbios não convencionais (de alta taxa) tratando águas residuárias de suinocultura: tipo, características, condições de operação e desempenho dos reatores e características da água residuária afluente.

\begin{tabular}{|c|c|c|c|c|c|c|c|c|c|c|c|}
\hline \multirow[t]{2}{*}{$\begin{array}{l}\text { Tipo de reator } \\
\text { Publicação }\end{array}$} & \multirow{2}{*}{$\begin{array}{l}\text { Volume } \\
\text { reator } \\
(\mathrm{L})\end{array}$} & \multirow{2}{*}{$\begin{array}{c}\text { Temp. } \\
\text { Op. } \\
\left({ }^{\circ} \mathrm{C}\right) \\
\end{array}$} & \multirow{2}{*}{$\begin{array}{c}\text { TDH } \\
\text { (h) }\end{array}$} & \multicolumn{3}{|c|}{$\begin{array}{c}\text { Características do afluente } \\
\left(\mathrm{mg} . \mathrm{L}^{-1}\right) \\
\end{array}$} & \multicolumn{3}{|c|}{$\begin{array}{c}\text { Eficiência de remoção } \\
(\%) \\
\end{array}$} & \multicolumn{2}{|c|}{$\begin{array}{c}\text { Produção de } \mathrm{CH}_{4} \\
\text { volumétrica específica }\end{array}$} \\
\hline & & & & DQO & SST & ST & DQO & SST & ST & (a) & (b) \\
\hline \multicolumn{12}{|l|}{ Filtro anaeróbio } \\
\hline HASHEIDER \& SIEVERS (1984) & 3,3 & 35 & 72 & 2487 & & 1412 & 86 & & 74 & 0,156 & 0,325 \\
\hline \multicolumn{12}{|l|}{ Horizontal com chicanas } \\
\hline \multirow[t]{2}{*}{ YANG \& CHOU (1985) } & 20 & 30 & 19 & 1800 & 770 & & 81,2 & 78,9 & & & 0,052 \\
\hline & & & 32 & 3090 & 1140 & & 80,9 & 88,2 & & 0,08 & 0,036 \\
\hline \multicolumn{12}{|l|}{ UASB } \\
\hline \multirow[t]{2}{*}{ VIÑAS et al . (1995) } & 18 & 26 & 36 & 13080 & & & 57 & & & 1,66 & 0,19 \\
\hline & & & 96 & 15200 & & & 73 & & & 0,91 & 0,24 \\
\hline CINTOLI et al . (1995) & 3,5 & mesof. & 21,2 & 11000 & & & 70 & & & & \\
\hline \multirow[t]{2}{*}{ SANCHEZ et al. (1995) } & 6,75 & 35 & & $4400 \mathrm{a}$ & $1900 \mathrm{a}$ & & $12,1 \mathrm{a}$ & $11,5 \mathrm{a}$ & & & \\
\hline & & & & 11800 & 43200 & & 58,3 & 59,1 & & & \\
\hline \multirow[t]{2}{*}{ KALYUZHNYI et al . (2000) } & 2,6 & 20 a 30 & $24 \mathrm{a}$ & $7100 \mathrm{a}$ & & & $60 \mathrm{a}$ & & & & \\
\hline & & & 33,6 & 10000 & & & 85 & & & & \\
\hline KALYUZHNYI et al. (1999) & 2,6 & 35 & 28,6 & 14700 & 2000 & & 77 & & & 4,14 & \\
\hline \multirow[t]{5}{*}{ OLIVEIRA (1997) } & 10,5 & amb. & 8 & 952 & 467 & & 85 & 88 & & & \\
\hline & & amb. & 27 & 3015 & 1630 & & 92 & 95 & & 0,301 & 0,124 \\
\hline & & amb. & 29 & 3971 & 2274 & & 90 & 93 & & 0,400 & 0,139 \\
\hline & & 25 & 12 & 3832 & 1978 & & 85 & 89 & & 0,931 & 0,146 \\
\hline & & 30 & 12 & 3709 & 1993 & & 87 & 91 & & 1,151 & 0,179 \\
\hline \multirow[t]{2}{*}{ OLIVEIRA (2000) } & 705 & 21 a 25 & 14,7 & & $750 \mathrm{a}$ & & & 70 a 90 & & 0,393 a & \\
\hline & & & & & 2300 & & & & & 0,589 & \\
\hline \multirow[t]{2}{*}{ OLIVEIRA (2001) } & 705 & 19,8 & 7,3 & 3361 & 1338 & & 71 & 69 & & 0,886 & \\
\hline & & 24,9 & 7,3 & 3731 & 2197 & & 81 & 85 & & 0,862 & \\
\hline \multicolumn{12}{|l|}{ Híbrido de UASB } \\
\hline CINTOLI et al . (1995) & 3,5 & mesof. & 46,7 & 11000 & & & 78 & & & & \\
\hline LO et al. (1994) & 14,75 & 22 a 28 & 79 & 12000 & & & $57-61$ & & & 0,71 & \\
\hline \multicolumn{12}{|l|}{ Filme fixo e leito expandido } \\
\hline \multirow[t]{2}{*}{ NG \& CHIN (1988) } & 14,75 & 30 & 24 & 8140 & 4620 & & 89 & 82 & & 0,333 & 0,046 \\
\hline & & & 48 & 4140 & 3250 & & 78 & 88 & & 0,166 & 0,103 \\
\hline
\end{tabular}

${ }^{(a)} \mathrm{L} \mathrm{CH}_{4}\left(\mathrm{~L}_{\text {reator.d }} \mathrm{d}^{-1}\right),{ }^{(\mathrm{b})} \mathrm{L} \mathrm{CH}_{4}$. $\left(\mathrm{g}\right.$ DQO total removida) ${ }^{-1}$.

Fonte: Adaptado de OLIVEIRA (1997).

Em virtude disto, têm sido realizados trabalhos utilizando-se os reatores UASB e híbridos de UASB, os quais combinam construção e operação simplificada com a capacidade de acomodar altas cargas orgânicas e hidráulicas (LETTINGA et al., 1980), para tratamento de águas residuárias de suinocultura.

Lo et al. (1994) com afluente com DQO de $12000 \mathrm{mg} \cdot \mathrm{L}^{-1}$ e TDH de $79 \mathrm{~h}$ obtiveram remoção de DQO de 57 a 61\%. Cintoli et al. (1995), utilizando sedimentação ou centrifugação 
da água residuária bruta, adição de zeólitos ao afluente e recirculação do efluente $\left(\mathrm{Q}_{\mathrm{r}} / \mathrm{Q}_{\mathrm{i}}=0,7\right.$ a 4,0); observaram no reator UASB remoção de DQO de 70\%, com TDH de 21,2 h, e no reator híbrido de UASB remoção de DQO de 78\%, com TDH de 46,7 h, para afluente com SST de 2000 a $5000 \mathrm{mg} . \mathrm{L}^{-1}$. Viñas et al. (1995) obtiveram, em reator UASB, remoção de DQO de 57 a 73\%, com TDH variando de 36 a 96 h e DQO do afluente de 13080 a 15200 mg. $\mathrm{L}^{-1}$. Sanchez et al. (1995) aplicaram TCOV de $5 \mathrm{~kg}$ DQO. $\mathrm{m}^{-3} \cdot \mathrm{d}^{-1}$ em reator UASB, com afluente com DQO de 4400 a 11800 mg.L $L^{-1}$ e SST de 1900 a 43200 mg.L.-1, obtendo eficiências de remoção de DQO e SST de 12 a 59\%.

Kalyuzhnyi et al. (2000), em reator UASB de bancada (2,6 L), aplicaram TCOV de 4 a $6 \mathrm{~kg} \mathrm{DQO}$ total $\cdot \mathrm{m}^{-3} \cdot \mathrm{d}^{-1}$, com TDH de 24,0 a 33,6 h e afluente, pré-acidificado ou filtrado, com DQO $_{\text {total }}$ de 7100 a 10000 mg.L $\mathrm{L}^{-1}$ e DQO devido à fração de sólidos suspensos de 600 a 2100 mg. $\mathrm{L}^{-1}$, e alcançaram eficiências de remoção de $\mathrm{DQO}_{\text {total }}$ de 60 a $85 \%$ e de DQO devido a sólidos suspensos de 67 a 89\%. Kalyuzhnyi et al. (1999) aplicaram TCOV de 12,39 kg $\mathrm{DQO}_{\text {total }} \cdot \mathrm{m}^{-3} \cdot \mathrm{d}^{-1}$, com o afluente, pré-acidificado, com concentrações de SST de $2000 \mathrm{mg} \cdot \mathrm{L}^{-1} \mathrm{e}$ DQO $_{\text {total de }} 14700 \mathrm{mg} . \mathrm{L}^{-1}$, com TDH de 28,6 h, e observaram eficiência de remoção de $\mathrm{DQO}_{\text {total }}$ de $77 \%$ e produção volumétrica de $4,14 \mathrm{~m}^{3} \mathrm{CH}_{4} \cdot \mathrm{m}^{-3}$ reator. $\mathrm{d}^{-1}$.

No Brasil, Oliveira (1997) obteve bons resultados, utilizando reatores UASB de bancada $(10,5 \mathrm{~L})$, para tratamento de águas residuárias de suinocultura com concentrações de DQO $_{\text {total de }} 952$ a 4013 mg. $\mathrm{L}^{-1}$ e de SST de 467 a $2274 \mathrm{mg} . \mathrm{L}^{-1}$, com TDH de 8 a $30 \mathrm{~h}$, observando eficiências de remoção de DQO $_{\text {total de }} 75$ a $92 \%$ e de SST de 77 a $95 \%$ e produções volumétricas de 0,072 a $1,151 \mathrm{~m}^{3} \mathrm{CH}_{4} \cdot \mathrm{m}^{-3}$ reator. $\mathrm{d}^{-1}$.

Oliveira (2000) obteve eficiências de remoção de DQO total e SST de 70 a 90\% e produções volumétricas de 0,393 a $0,589 \mathrm{~m}^{3} \mathrm{CH}_{4} \cdot \mathrm{m}^{-3}$ reator. $\mathrm{d}^{-1}$, operando dois reatores UASB de $705 \mathrm{~L}$ cada, instalados em série, com TDH de 14,7 h em cada reator, TCOV de 5 a $8 \mathrm{~kg}$ DQO. $\mathrm{m}^{-3} \cdot \mathrm{d}^{-1}$ no primeiro reator, e concentração de SST do afluente de 750 a $2300 \mathrm{mg} . \mathrm{L}^{-1}$. Dando continuidade ao trabalho, Oliveira (2001) operou os dois reatores UASB de 705 L, instalados em série, com TDH de 7,3 h em cada reator, TCOV de 11 a $14 \mathrm{~kg}$ DQO. $\mathrm{m}^{-3} \cdot \mathrm{d}^{-1}$ no primeiro reator, com o afluente com valores médios de SST de 1338 a 2197 mg.L $\mathrm{L}^{-1}$, e adotou a prática de descarte periódico do excesso de lodo. Os valores médios da efíciência de remoção de $\mathrm{DQO}_{\text {total }}$ foram de 71 e $81 \%$ e de SST de 69 e $85 \%$, e as produções volumétricas de 0,886 e $0,862 \mathrm{~m}^{3} \mathrm{CH}_{4} \cdot \mathrm{m}^{-3}$ reator. $\mathrm{d}^{-1}$, com temperaturas médias de 19,8 e $24,9{ }^{\circ} \mathrm{C}$, respectivamente.

Assim, a possibilidade de utilização do reator UASB para tratamento de águas residuárias de suinocultura com valores de remoções de DQO e sólidos acima de $70 \%$ e 
rendimentos satisfatórios de $\mathrm{CH}_{4}$ está configurando-se como promissora. $\mathrm{Na}$ maioria dos trabalhos utilizou-se reator UASB em um estágio abrangendo concentrações de SST do afluente de 500 a $5000 \mathrm{mg} . \mathrm{L}^{-1}$, considerando-se a utilização de tratamento primário com boa eficiência para a separação sólido-líquido, tendo em vista que a concentração de sólidos do resíduo bruto varia de 0,5 a 4,0\%. Apesar das limitações do reator UASB relacionadas à concentração de SST do afluente, existem indicações (OLIVEIRA, 2000, 2001, VAN LIER et al., 2001, VAN HAANDAL e LETTINGA, 1994,) para ampliar estes limites, que não foram estabelecidos, com a alternativa de sua aplicação em dois estágios. Melhorando-se as condições para hidrólise dos sólidos orgânicos e, com isso, minimizando-se os efeitos negativos sobre a manta de lodo, abre-se a possibilidade de diminuição ou até eliminação da infra-estrutura para tratamento primário dos dejetos brutos de suinocultura e de outras águas residuárias industriais. 


\section{MATERIAL E MÉTODOS}

\subsection{Local}

A pesquisa foi desenvolvida no Laboratório de Processos Anaeróbios do Departamento de Hidráulica e Saneamento da Escola de Engenharia de São CarlosEESC/USP, no Município de São Carlos-SP.

\subsection{Instalações experimentais}

A unidade experimental em dois estágios foi constituída por dois reatores UASB de bancada, instalados em série (escala 4:1), com volume total de 39,0 L (primeiro estágio) e 10,5 L (segundo estágio), tanque de alimentação com agitação, tanque para armazenamento do efluente, bomba tipo diafragma, selos hidráulicos e dispositivos para monitoramento da produção de biogás, medindo-se o deslocamento de líquido (frascos Mariot), conforme ilustrado na Figura 3.1. A unidade experimental foi montada em compartimento construído em madeira sobre bancada com sistema para controle da temperatura na faixa de 25 a $30^{\circ} \mathrm{C}$. 


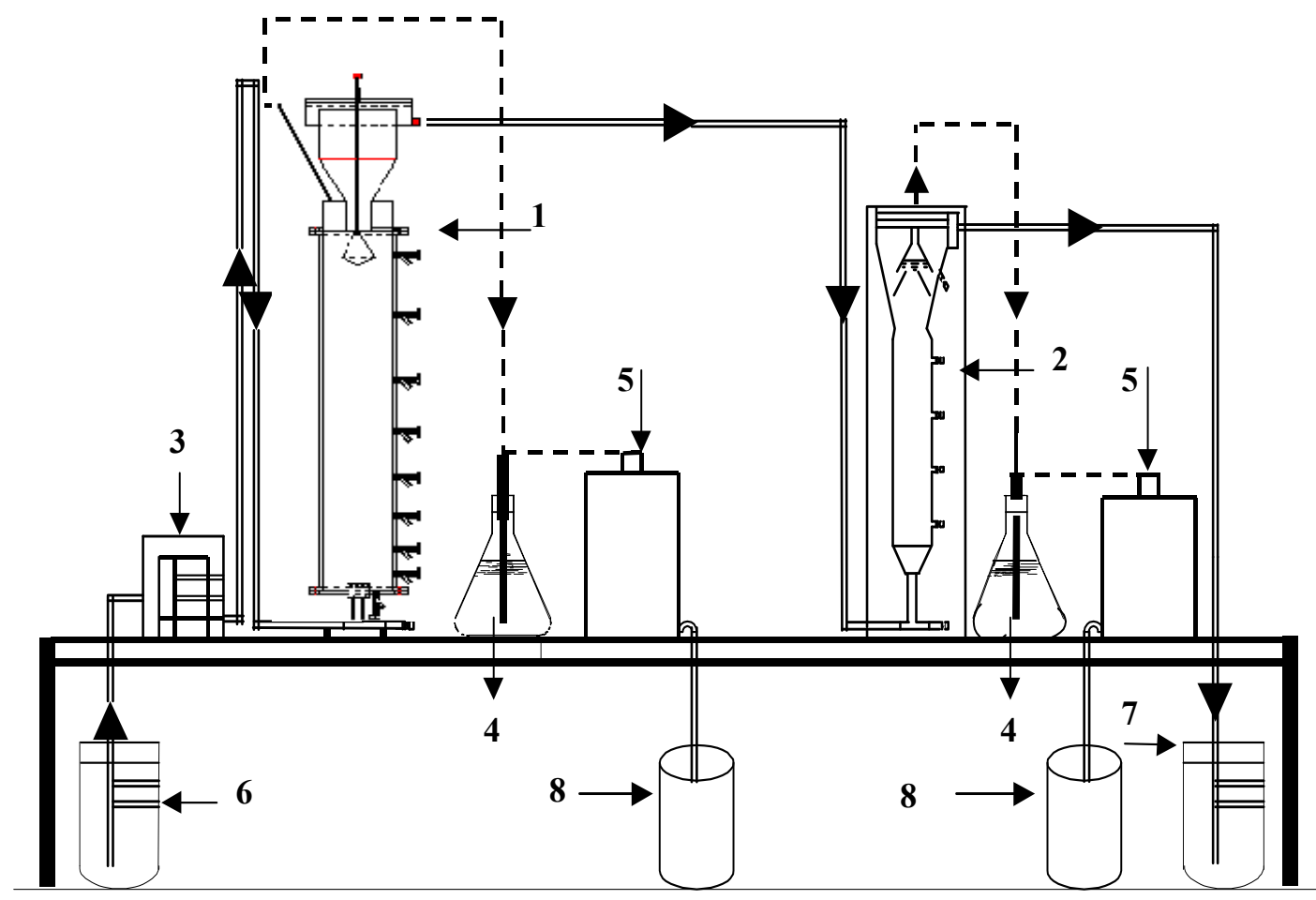

Figura 3.1 Esquema do sistema de dois estágios com reatores UASB de bancada: (1) Reator UASB 39,0 L, (2) Reator UASB 10,5 L, (3) Bomba tipo diafragma, (4) Selo hídrico, (5) Frasco Mariot, (6) Afluente, (7) Efluente, (8) Coletor de líquido deslocado.

O primeiro reator UASB, com volume total de 39,0 L, descrito por Matsumoto (1995) e esquematizado nas Figuras 3.2 e 3.3, foi construído com tubo de acrílico de diâmetro interno de $190 \mathrm{~mm}$ e altura de $1,00 \mathrm{~m}$. Foram instalados dispositivos de entrada e saída do reator. O dispositivo de entrada tem forma de tampa e foi construído de acrílico, provido de um difusor de oito furos, em PVC, instalado no centro da tampa, com a finalidade de homogeneizar a entrada do substrato no reator. Este dispositivo foi acoplado ao tubo através de flange e anel de vedação.

O dispositivo de saída foi construído com folhas de latão de 1,02 $\mathrm{mm}$ de espessura, em forma de funil, subdividido em três partes: zona de sedimentação, câmara de gás e separador de fases.

O separador de fases foi construído com polímero a base de óleo de mamona, na forma de dois cones contrapostos e suspenso por haste regulável.

O segundo reator UASB, com volume total de 10,5 L, construído por Del Nery (1993) e esquematizado na Figura 3.4, foi construído com duas faces paralelas em acrílico comprimidas contra o contorno das paredes laterais, em aço inoxidável e fixadas com parafusos. Entre os contornos de aço inoxidável e as faces de acrílico foram colocados cordões de borracha para selar as interfaces das placas. 

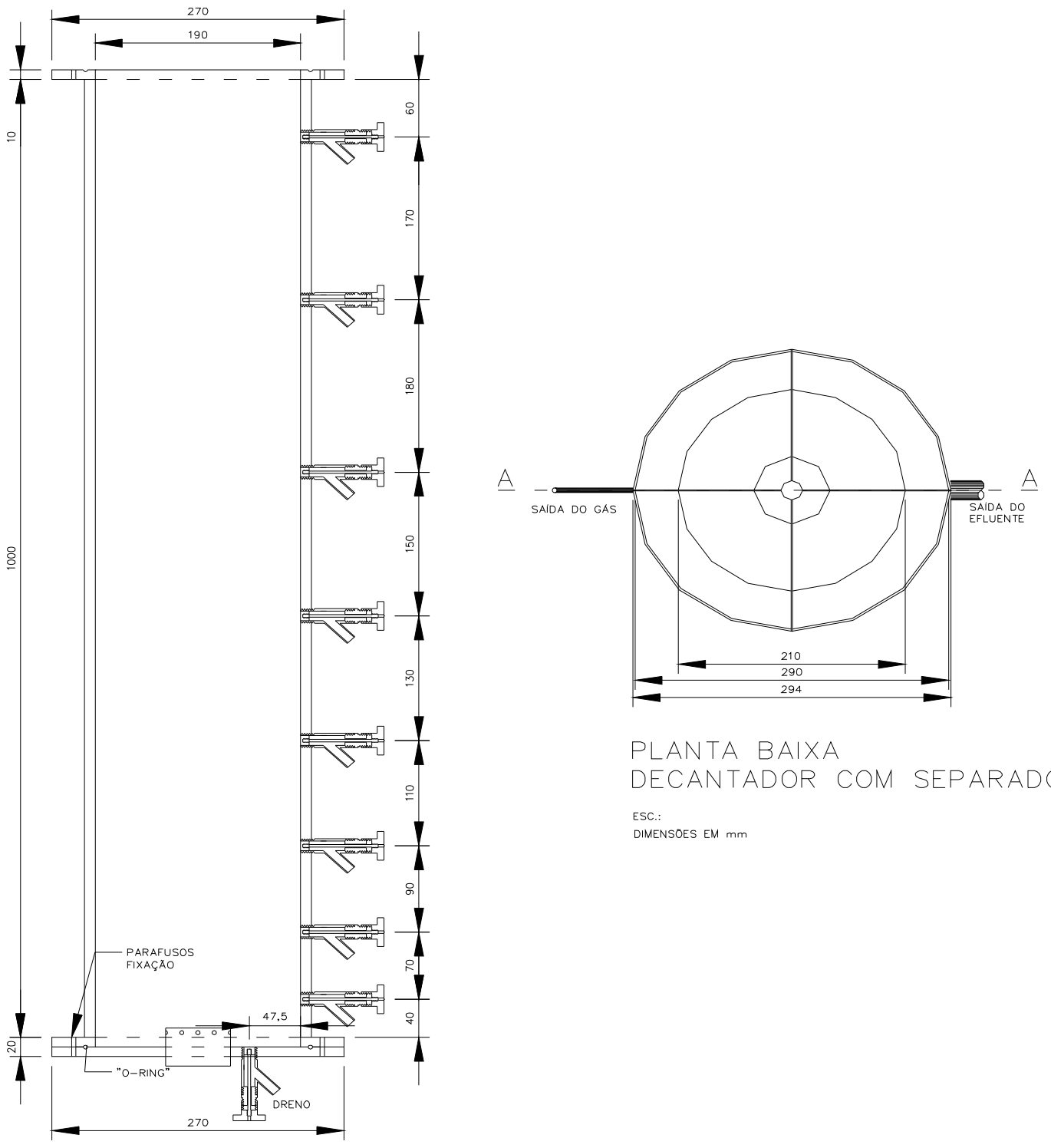

PLANTA BAIXA

DECANTADOR COM SEPARADOR DE GAS Esc:

GIMENSOES EM mm

CORTE REATOR UASB

ESC:

DIMENSÖES EM mr

Figura 3.2. Vista frontal e superior do primeiro reator UASB $(39,0 \mathrm{~L})$ 


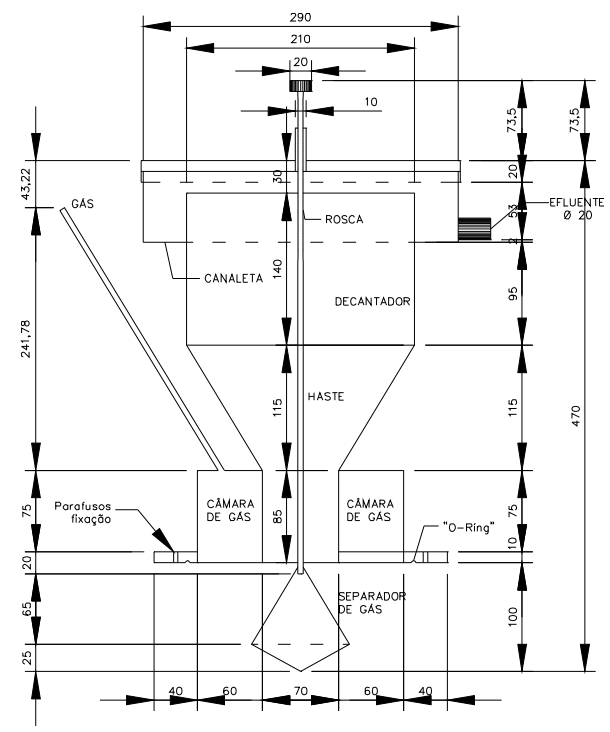

CORTE AA

DECANTADOR COM SEPARADOR DE GÁS

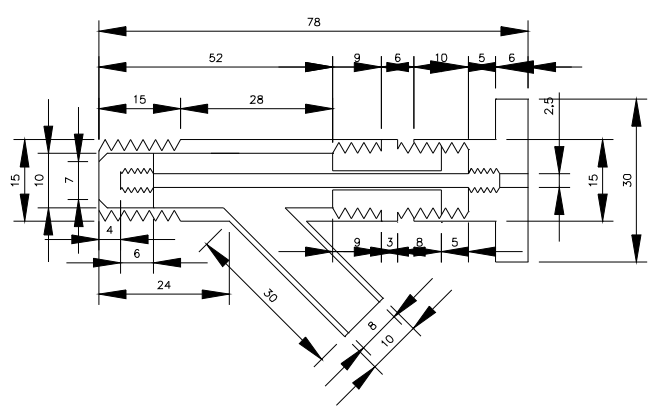

DETALHE DO AMOSTRADOR OMMENSEES EM mm

Figura 3.3. Vista frontal do separador de gases e amostrador do primeiro reator UASB (39,0 L) 
O reator foi composto de uma zona de entrada divergente na parte inferior, com forma de tronco de pirâmide de $5 \mathrm{~cm}$ de altura, provida, na parte superior, de placa de aço inoxidável perfurada, com a finalidade de homogeneizar a distribuição do afluente. Acima tem-se a zona de reação, com forma prismática de seção longitudinal retangular, com $45 \mathrm{~cm}$ de altura e seção transversal quadrada, com $12 \mathrm{~cm}$ de lado, a qual tem sua largura gradualmente aumentada para formar a zona de sedimentação no topo. O separador sólido/gás/líquido localizado acima e adjacente à zona de reação tem forma piramidal, ocupa parte da zona de sedimentação e é formado por placas de aço inoxidável com inclinação de aproximadamente $55^{\circ}$.

O efluente líquido foi coletado por três tubos de aço inoxidável, com $1 \mathrm{~cm}$ de diâmetro, perfurados e submersos, uniformemente, na superfície do líquido no sedimentador e conectados à canaleta de saída no topo do reator, a partir de onde o líquido é descartado por meio de mangueira de silicone, armazenado em recipiente plástico e, após, lançado na rede de esgotos do laboratório.

O gás foi coletado no topo do primeiro e segundo reatores, na câmara de gás, por mangueira de plástico e conduzido para os frascos Mariot, após passar por selos hidráulicos construídos com erlenmeyer de 5000 e $1000 \mathrm{~mL}$, respectivamente, os quais mantiveram o gás sob pressão.

O primeiro reator foi construído com nove dispositivos intermediários para a coleta de amostras, oito ao longo da zona de reação e um no fundo, próximo à tubulação de entrada do reator. O segundo reator foi provido de seis tomadas intermediárias, quatro ao longo da zona de reação, uma na tubulação de entrada do reator e uma no sedimentador.

Para tanque de armazenamento do afluente foi utilizado recipiente plástico com capacidade de 30,0 L. O afluente era agitado, durante uma hora, por bomba de aquário, controlada por timer, marca Multi-Timer, com doze programas, com intervalos de uma hora entre cada período de agitação. $\mathrm{O}$ afluente foi bombeado para o primeiro reator por meio de mangueiras de silicone, utilizando-se bomba tipo diafragma, marca Guarujá.

Os frascos Mariot, dispositivos de deslocamento de líquido para medida do volume de gás produzido, foram construídos com galões de plástico de água mineral e acoplados aos selos hidráulicos por meio de mangueiras plásticas. Os galões foram graduados para medida do volume de gás produzido e possuíam capacidade para 20,0 e 10,0 L e foram instalados no primeiro e segundo reatores, respectivamente. 


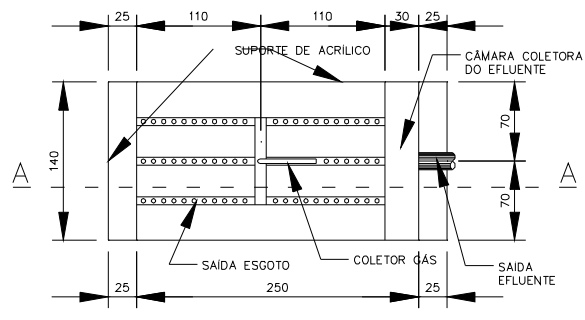

PLANTA BAIXA REATOR UASB DMMENSESS EM mM

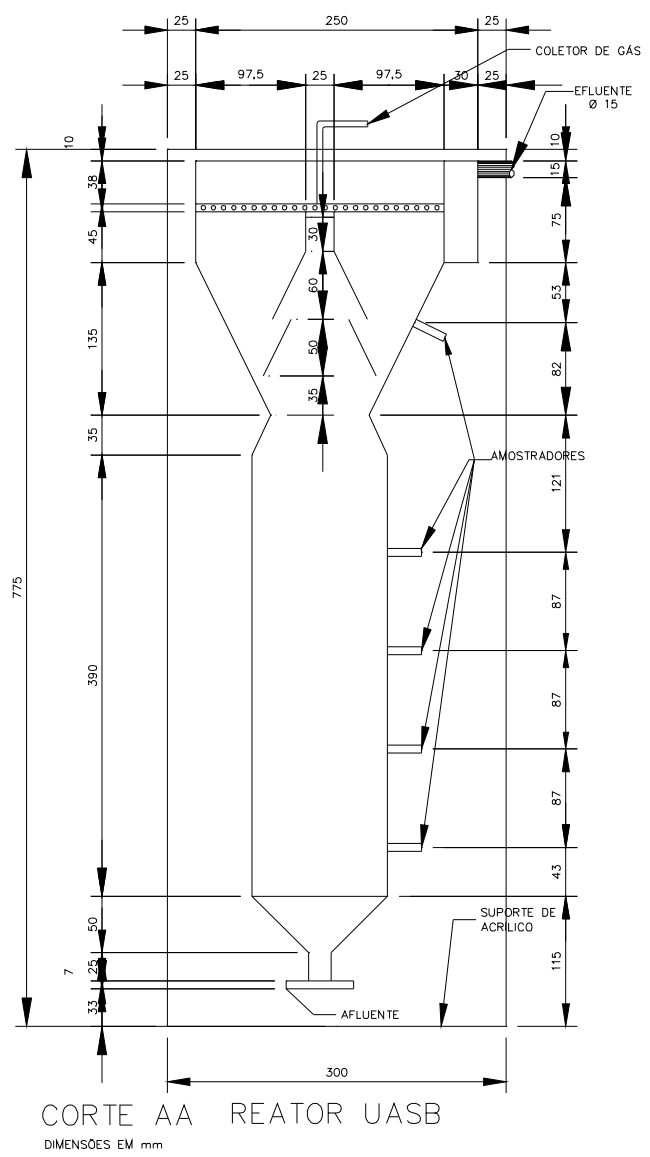

Figura 3.4. Vista frontal e superior do segundo reator UASB (10,5 L) 


\section{3. Água residuária}

A água residuária utilizada para alimentação dos reatores UASB foi o esterco de suínos diluído com água de torneira e pré-peneirado (peneira com malha quadrada de abertura $2 \mathrm{~mm}$ ), para obtenção de concentração de sólidos suspensos totais (SST) em torno de 5000 $\operatorname{mg} \cdot L^{-1}$.

O esterco bruto utilizado para preparar o resíduo diluído foi coletado em confinamento de suínos na fase de terminação, alimentados com ração à base de milho e soja com complemento vitamínico e mineral, na Fazenda Itaiúba, município de São Carlos. O esterco bruto foi acondicionado em sacos plásticos e mantido sob refrigeração de 0 a $-10^{\circ} \mathrm{C}$ para utilização diária. De cada lote de esterco coletado foram feitas análises de sólidos totais (ST) e voláteis (SV).

Sabendo-se a concentração de ST, foi pesada quantidade de esterco bruto, pré-diluído e homogeneizado na concentração de ST em torno de 1\%, e mantido em repouso por 15 min para que a maior parte das partículas discretas sedimentasse.

O líquido sobrenadante foi então peneirado para separação dos sólidos que pudessem entupir a linha de alimentação do reator. Depois foram tomadas amostras para determinação de SST, tornando possível calcular os volumes de água a serem adicionados para se obterem as concentrações de SST desejadas. Este procedimento foi realizado para cada lote de esterco bruto coletado.

A água residuária, com a concentração de SST desejada, foi preparada diariamente.

\subsection{Descrição da operação do sistema de tratamento}

O experimento foi dividido em 3 ensaios, com temperatura controlada na faixa de 25 a $30^{\circ} \mathrm{C}$. As instalações do experimento com temperatura controlada estão ilustradas na Figura 3.5 .

O primeiro reator foi alimentado com o afluente com concentração de SST de 5240 mg. $\mathrm{L}^{-1}$ no ensaio 1; $5000 \mathrm{mg} . \mathrm{L}^{-1}$ no ensaio 2; e $5490 \mathrm{mg} . \mathrm{L}^{-1}$ no ensaio 3. O efluente do primeiro reator foi conduzido por meio de mangueiras de silicone, por gravidade, para o segundo reator.

Os reatores foram submetidos a tempos de detenção hidráulico (TDH) de 62, 31 e 16 h no primeiro e no segundo de 16,8 e $4 \mathrm{~h}$. A diminuição do TDH permitiu a operação com 
aumentos da taxa de carregamento orgânico volumétrico (TCOV), da taxa de carregamento no lodo (TCL) e da carga hidráulica volumétrica (CHV).

Os ensaios do experimento tiveram duração de no mínimo 41 e no máximo 59 dias.

$\mathrm{Na}$ diminuição do TDH de 62 para $31 \mathrm{~h}$, o primeiro e segundo reatores foram submetidos a TDH intermediários de 46 e 12 h, respectivamente, sendo operados por período de 21 dias nesta condição. Foi adotado o mesmo procedimento na troca de TDH de 31 para 16 $\mathrm{h}$, aplicando-se TDH de $18 \mathrm{~h}$ no primeiro reator e $5 \mathrm{~h}$ no segundo reator por período de 24 dias. Esse procedimento foi adotado para evitar sobrecarga orgânica no sistema.

$\mathrm{Na}$ Tabela 3.1 estão apresentadas as condições operacionais para os ensaios 1, 2 e 3 do experimento, nas quais foram verificadas o desempenho dos reatores UASB operados em série no sistema de dois estágios.

Tabela 3.1. Condições de operação do primeiro (r1) e segundo (r2) reator UASB nos ensaios 1,2 e 3 do sistema em dois estágios.

\begin{tabular}{|c|c|c|c|c|c|c|c|c|c|}
\hline \multirow[t]{2}{*}{ Ensaio } & \multicolumn{2}{|c|}{$\begin{array}{l}\text { TDH } \\
\text { (h) } \\
\end{array}$} & \multirow{2}{*}{$\begin{array}{l}\text { Duração } \\
\text { (d) }\end{array}$} & \multirow{2}{*}{$\begin{array}{c}\begin{array}{c}\mathrm{SST} \\
\text { afluente } \\
\left(\mathrm{mg} \mathrm{L}^{-1}\right)\end{array} \\
\mathrm{r} 1\end{array}$} & \multirow{2}{*}{$\begin{array}{l}\mathrm{DQO}_{\text {total }} \\
\text { afluente } \\
\text { (mg L-1) }\end{array}$} & $(\mathrm{kg} \mathrm{D}$ & $\left.\left(m^{3} d\right)^{-1}\right)$ & \multicolumn{2}{|c|}{$\begin{array}{l}\text { CHV } \\
\left(\mathrm{h}^{-1}\right)\end{array}$} \\
\hline & $\mathrm{r} 1$ & $\mathrm{r} 2$ & & & & $\mathrm{r} 1$ & $\mathrm{r} 2$ & $\mathrm{r} 1$ & $\mathrm{r} 2$ \\
\hline Ensaio 1 & 62 & $\overline{16}$ & 46 & 5240 & 11740 & 4,55 & 2,55 & 0,016 & 0,06 \\
\hline Ensaio 2 & 31 & 8 & 59 & 5000 & 11292 & 8,75 & 4,75 & 0,032 & 0,12 \\
\hline Ensaio 3 & 16 & 4 & 41 & 5490 & 12306 & 18,65 & 21,03 & 0,063 & 0,24 \\
\hline
\end{tabular}

TCOV - taxa de carregamento orgânico volumétrico e CHV - carga hidráulica volumétrica

\subsection{Procedimentos de partida}

\subsubsection{Lodo de inóculo}

Para inóculo foi utilizado lodo de reatores UASB, em escala piloto, tratando dejetos de suínos, instalados no Depto. de Engenharia Rural da FCAV/UNESP, Campus de Jaboticabal. Foi adicionado lodo na quantidade necessária para ocupar $50 \%$ do volume dos reatores, para manter-se no primeiro reator taxa de carregamento orgânico no lodo (TCL) de 0,1 a $0,2 \mathrm{~kg}$ $\mathrm{DQO}_{\text {total }} \cdot \mathrm{kg} \mathrm{SV}^{-1} \cdot \mathrm{d}^{-1}$.

A concentração de SV do lodo de inóculo foi de $41000 \mathrm{mg} \cdot \mathrm{L}^{-1}$. 
O lodo apresentou-se com poucos grânulos e pequenos, com grande quantidade de sólidos finos.

\subsubsection{Partida}

Na partida, com TDH de 62 h no primeiro reator e afluente com concentração de sólidos suspensos totais (SST) em torno $2000 \mathrm{mg} \cdot \mathrm{L}^{-1}$, os reatores foram inoculados, respectivamente, com 15,0 e 5,0 L de lodo, no primeiro e segundo reatores, correspondendo a, aproximadamente, $600000 \mathrm{mg}$ e $200000 \mathrm{mg}$ de SV. O volume restante dos reatores foi completado com o afluente com concentração de SST em torno de 2000 mg.L.'

A operação foi iniciada com taxa de carregamento orgânico volumétrico (TCOV) de $1,79 \mathrm{~kg}$ DQO. $\mathrm{m}^{-3} \cdot \mathrm{d}^{-1}$ para o primeiro reator. O sistema foi operado nessas condições por um período de 19 dias.

Após, quando verificou-se a estabilidade do sistema (Item 4.1.1), por meio dos parâmetros de controle: ácidos voláteis totais, produção e composição do biogás, remoção de DQO e SS, aumentou-se a concentração de SST para valores em torno de $5000 \mathrm{mg} . \mathrm{L}^{-1} \mathrm{e}$ iniciou-se o ensaio 1 do experimento (TDH $62 \mathrm{~h}$ no primeiro reator). 


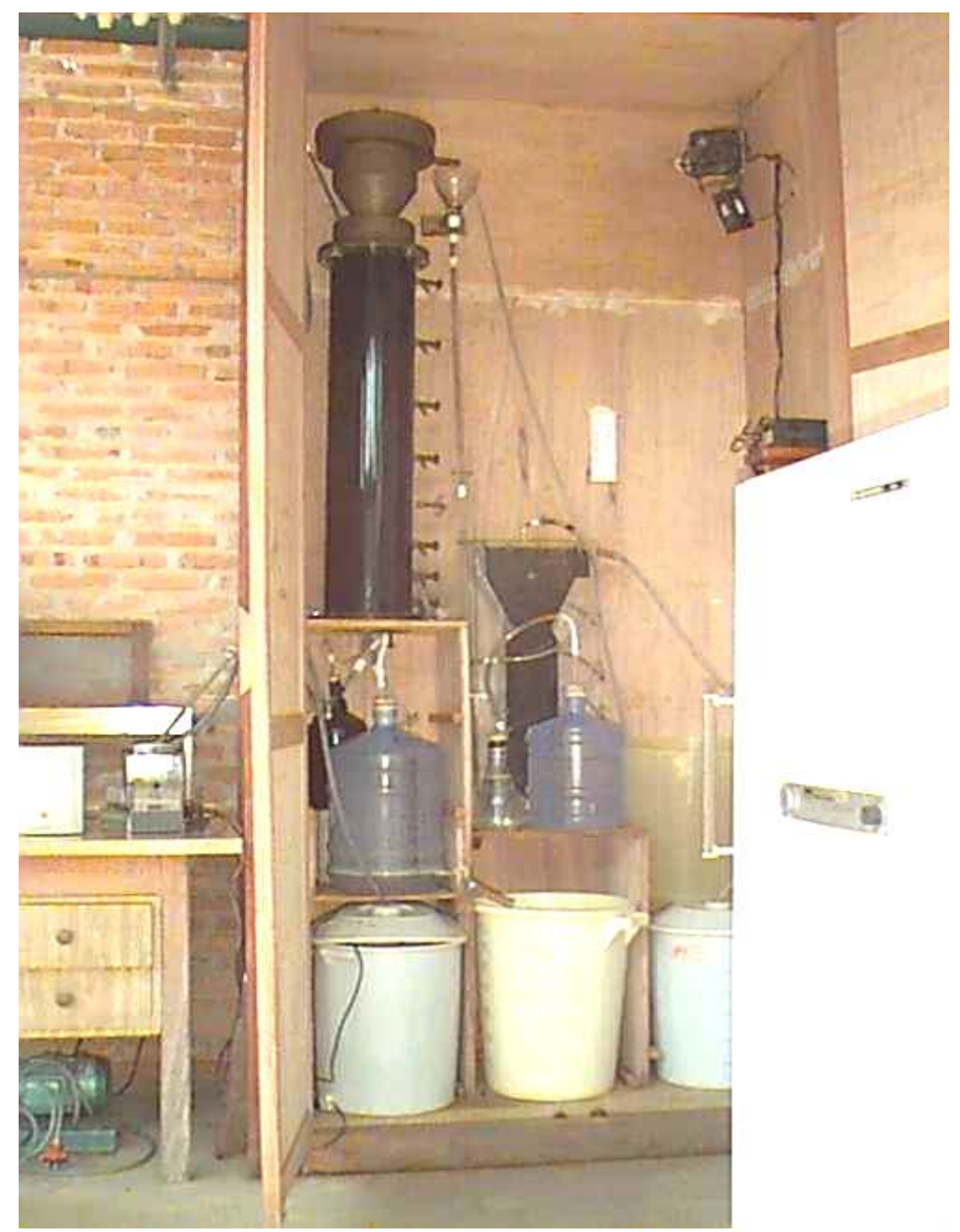

Figura 3.5. Unidade experimental operada com temperatura controlada

\subsection{Exames físicos e determinações de constituintes orgânicos e inorgânicos não metálicos}

\subsubsection{Amostragem}

Os afluentes e efluentes foram coletados nas mangueiras de alimentação e de saída do primeiro reator, e na saída do segundo reator. Para os exames e determinações foram utilizadas amostras compostas com sub-amostras de 50 a $100 \mathrm{~mL}$, coletadas a cada meia hora, no período das 7:00 as 13:00 h, para atenderem-se os limites de tempo para armazenamento 
de amostras líquidas. $\mathrm{O}$ volume coletado para cada amostra foi em torno de $500 \mathrm{~mL}$, sendo suficiente para a realização de todos os exames e determinações.

Foram coletadas amostras de lodo dos reatores, no início do experimento, do lodo de inóculo e ao longo do experimento a cada quinze dias, aproximadamente, para determinação de ST, SV e SF. As amostras foram retiradas por meio das tomadas intermediárias laterais 1 , 3, 5, 7 e 8, no primeiro reator, e 1, 2, 3, 4 e 5, no segundo reator (Figuras 3.2 e 3.4). O volume de amostras coletadas da manta dos reatores foi de $100 \mathrm{~mL}$ em cada tomada de amostragem.

$\mathrm{O}$ volume de gás produzido, diariamente, foi determinado medindo-se o deslocamento de líquido dos frascos Mariot, por meio de escala graduada, construída nos frascos, e simultaneamente a temperatura da câmara, para correção dos valores para as CNTP.

As coletas de amostras de biogás para cromatografia foram feitas, com seringa de 1 $\mathrm{mL}$, em ponto de coleta instalado entre a mangueira de saída do biogás e o selo hidráulico. Utilizou-se cromatógrafo série 150, modelo 69-152 marca Gow-Mac equipado com coluna Poropak-Q, comprimento $2 \mathrm{~m}$, diâmetro interno $1 / 4$ ", temperatura de operação $70^{\circ} \mathrm{C}$, corrente 150mA, acoplado a integrador HP 3396 série II. Marca Hewlett-Packard. Os resultados referem-se à porcentagem de $\mathrm{CH}_{4}$ em relação à mistura metano, gás carbônico e ar (predominantemente $\mathrm{N}_{2}$ ).

Foi instalado um termômetro de máxima e mínima no interior do compartimento da unidade experimental para monitoramento diário da temperatura.

\subsubsection{Freqüência de amostragem e metodologias utilizadas para monitoramento dos reatores}

Na Tabela 3.2 estão apresentados os exames físicos e as determinações de constituintes orgânicos e inorgânicos não metálicos a serem efetuadas nas amostras compostas coletadas, a freqüência de realização e as fontes das metodologias utilizadas. 
Tabela 3.2. Exames e determinações, freqüência e fontes das metodologias utilizadas.

\begin{tabular}{|c|c|c|c|c|c|c|}
\hline \multirow[t]{2}{*}{ Exames e determinações: } & \multicolumn{5}{|c|}{ Periodicidade } & \multirow{2}{*}{$\begin{array}{c}\text { Referência } \\
\text { Bibliográfica }\end{array}$} \\
\hline & diária & $\begin{array}{c}\text { três } \\
\text { por } \\
\text { semana } \\
\end{array}$ & $\begin{array}{c}\text { sema } \\
\text { nal }\end{array}$ & $\begin{array}{c}\text { quinze } \\
\text { nal }\end{array}$ & $\begin{array}{l}\text { cada } \\
\text { TDH }\end{array}$ & \\
\hline \multicolumn{7}{|l|}{ Afluentes e efluentes } \\
\hline $\mathrm{pH}$ & & $\bar{X}$ & & & & APHA, (1992) \\
\hline Temperatura & $\mathrm{X}$ & & & & & APHA, (1992) \\
\hline $\begin{array}{l}\text { Alcalinidades: total (AT), } \\
\text { intermediária (AI) e parcial } \\
\text { (AP) }\end{array}$ & & $\mathrm{X}$ & & & & $\begin{array}{c}\text { APHA, (1992) } \\
\text { Jenkins et al. (1983) }\end{array}$ \\
\hline Ácidos voláteis totais (AVT) & & $\mathrm{X}$ & & & & Dilallo e Albertson (1961) \\
\hline $\begin{array}{l}\text { Concentrações individuais dos } \\
\text { ácidos voláteis intermediários }\end{array}$ & & & & & $\mathrm{X}$ & $\begin{array}{l}\text { Moraes et al. (2000) } \\
\text { (cromatografia gasosa) }\end{array}$ \\
\hline $\begin{array}{l}\text { Demanda quím. de oxig. total } \\
\left(\mathrm{DQO}_{\mathrm{t}}\right) \text { e da fração dissolvida } \\
\left(\mathrm{DQO}_{\text {diss }}\right) \text { e devido aos sólidos } \\
\text { suspensos }\left(\mathrm{DQO}_{\mathrm{ss}}\right)\end{array}$ & & $\begin{array}{l}\mathrm{X} \\
\mathrm{X}\end{array}$ & & & & $\begin{array}{c}\text { APHA, (1992) } \\
\text { Oliveira (1997) } \\
\text { (método colorimétrico e } \\
\text { digestão com refluxo } \\
\text { fechado) } \\
\end{array}$ \\
\hline $\begin{array}{l}\text { Sólidos suspensos totais (SST), } \\
\text { voláteis (SSV), fixos (SSF) }\end{array}$ & & $\mathrm{X}$ & & & & APHA, (1992) \\
\hline $\begin{array}{l}\text { Nitrogênio total, amoniacal e } \\
\text { orgânico }\end{array}$ & & & & & $\mathrm{X}$ & $\begin{array}{c}\text { APHA, (1992) } \\
\text { (método titulométrico com } \\
\text { digestão semi-micro- } \\
\text { Kjeldahl) }\end{array}$ \\
\hline Fósforo total & & & & & $\mathrm{X}$ & $\begin{array}{c}\text { APHA, (1992) } \\
\text { (método colorimétrico do } \\
\text { ác. ascórbico e digestão } \\
\text { com persulfato) }\end{array}$ \\
\hline \multicolumn{7}{|l|}{ Biogás } \\
\hline Produção de biogás & $\mathrm{X}$ & & & & & Oliveira (1997) \\
\hline Composição do biogás & & & $\mathrm{X}$ & & & $\begin{array}{c}\text { APHA, (1992) } \\
\text { (cromatografia gasosa) }\end{array}$ \\
\hline \multicolumn{7}{|l|}{ Lodo } \\
\hline $\begin{array}{l}\text { Sólidos totais (ST), voláteis } \\
\text { (SV), fixos (SF) }\end{array}$ & & & & $X$ & & APHA, (1992) \\
\hline \multicolumn{7}{|l|}{ Esterco } \\
\hline ST, SV e SF & & & & & $\mathrm{X}$ & APHA, (1992) \\
\hline
\end{tabular}

A temperatura no interior da câmara foi medida por meio de termômetro de máxima e mínima, de vidro com enchimento de mercúrio, diariamente, no interior da câmara.

Para a determinação do $\mathrm{P}_{\text {total }}$ utilizou-se o método colorimétrico do ácido ascórbico e digestão com persulfato de potássio. Para a digestão utilizou-se $10 \mathrm{~mL}$ de amostra afluente e efluente e $1 \mathrm{~mL}$ de solução saturada de persulfato de potássio. As amostras foram autoclavadas à temperatura de $120{ }^{\circ} \mathrm{C}$ por trinta minutos. Após o processo de digestão verificou-se a presença de resíduos nos tubos e coloração amarelada, para as amostras do 
afluente e efluente do primeiro reator. Pela alta concentração de sólidos suspensos presentes na água residuária de alimentação com SST em torno de $5000 \mathrm{mg} . \mathrm{L}^{-1}$, a presença de impurezas poderia indicar uma digestão incompleta e conseqüentemente valores de $\mathrm{P}_{\text {total }}$ abaixo dos reais. O procedimento adotado para a confirmação dos dados obtidos foi variar o volume das amostras (Tabela 3.3). Utilizaram-se volumes do afluente e efluente brutos de 0,3; 0,$4 ; 0,5 ; 1,0 ; 2,0 ; 4,0 ; 6,0 ; 8,0$ e $10,0 \mathrm{~mL}$. Substituiu-se a solução saturada por persulfato em pó, fixando-se massa de $0,2 \mathrm{~g}$ por amostra. A etapa de digestão seguiu a metodologia citada acima. As amostras de soluções padrões foram digeridas da mesma forma que as amostras afluentes e efluentes de suinocultura.

A seguir, estudou-se a variação da massa de persulfato (Tabela 3.4) não observando variação significativa ao variar a massa de persulfato de 0,05 a $0,50 \mathrm{~g}$, mantendo-se o volume de amostra de água residuária de suinocultura em $0,4 \mathrm{~mL}$.

Tabela 3.3. Variação do volume de amostra de água residuária de suinocultura.

\begin{tabular}{cccc}
\hline Amostra & $\begin{array}{c}\text { Persulfato de } \\
\text { Potássio }\end{array}$ & \multicolumn{2}{c}{$\begin{array}{c}\text { P-total } \\
\left(\mathrm{mg}_{\mathrm{L}}{ }^{-1}\right)\end{array}$} \\
\cline { 3 - 4 }$(\mathrm{mL})$ & $\left(\mathrm{mg} \cdot \mathrm{L}^{-1}\right)$ & Afluente & Efluente \\
\hline 0,3 & 666 & 149,4 & 95,9 \\
0,4 & 500 & 164,3 & 97,0 \\
0,5 & 400 & 105,6 & 99,8 \\
1,0 & 200 & 77,5 & 97,2 \\
2,0 & 100 & 76,9 & 91,8 \\
4,0 & 50 & 72,6 & 89,2 \\
\hline
\end{tabular}

Estudou-se, ainda, o efeito da acidez adicionando-se $0,2 \mathrm{~mL}$ de ácido sulfúrico $30 \%$ nas amostras para digestão. Verificou-se que as concentrações de fosfato foram maiores para as amostras onde o ácido foi adicionado, visto que a presença do ácido faz com que os polifosfatos sejam convertidos a fosfatos. Para um volume de $0,4 \mathrm{~mL}$ de amostra de água residuária bruta de suinocultura, fixou-se o volume de ácido em 0,2 mL.

Após a digestão, as amostras foram diluídas e analisadas pela metodologia do FIA (Flow Injection Analysis) (APHA, AWWA, WPCF, 1992). Os melhores resultados foram obtidos com volumes de amostras de $0,4 \mathrm{~mL}$, os quais foram adotados e serão apresentados no item resultados. 
Tabela 3.4. Resultados obtidos variando a massa de persulfato de potássio.

\begin{tabular}{ccc}
\hline $\begin{array}{c}\text { Persulfato de } \\
\text { Potássio } \\
(\mathrm{g})\end{array}$ & $\begin{array}{c}\text { Persulfato de } \\
\text { Potássio } \\
\left(\mathrm{mg} . \mathrm{L}^{-1}\right)\end{array}$ & $\begin{array}{c}\text { P-total } \\
\left(\mathrm{mg} . \mathrm{L}^{-1}\right)\end{array}$ \\
\hline 0,05 & 100 & 7,6 \\
0,10 & 200 & 7,8 \\
0,20 & 400 & 7,9 \\
0,30 & 600 & 7,9 \\
0,40 & 800 & 8,0 \\
0,50 & 1000 & 7,8 \\
\hline
\end{tabular}

Para determinação de alcalinidade, ácidos voláteis totais e $\mathrm{DQO}_{\text {dissolvida }}$ as amostras de afluente e efluente foram centrifugadas por 15 minutos com rotação de $4500 \mathrm{rpm}$. Esse procedimento foi adotado devido à dificuldade de filtrar as amostras brutas em membranas. Após a centrifugação as amostras eram submetidas à filtração em membrana e o filtrado utilizado para determinação das variáveis acima.

As concentrações individuais dos ácidos voláteis foram determinadas em cromatógrafo gasoso HP 6890, equipado com detector de ionização de chama; coluna HP INNOWAX, 30m x $0,25 \mathrm{~mm}$ x 0,25 $\mu \mathrm{m}$ de espessura de filme; fluxo de gás de arraste (hidrogênio): 2,0 $\mathrm{mL} / \mathrm{min}$.; temperatura do forno: $100{ }^{\circ} \mathrm{C}(3 \mathrm{~min})-.180^{\circ} \mathrm{C}(5 \mathrm{~min}$. $), 5{ }^{\circ} \mathrm{C} / \mathrm{min}$.; temperatura do injetor: $250^{\circ} \mathrm{C}$; "split": 20 ; temperatura do detector: $300^{\circ} \mathrm{C}$; fluxo de ar sintético: $300 \mathrm{~mL} / \mathrm{min}$.; fluxo de hidrogênio: $30 \mathrm{~mL} / \mathrm{min}$; fluxo de gás auxiliar (nitrogênio): $33 \mathrm{~mL} / \mathrm{min}$.; range: 1 .

As amostras brutas do afluente e efluentes, em volume de 1,00 mL, foram destiladas, em capela, através de microdestilador colocado sobre manta aquecedora e conectado à água de refrigeração do condensador. No frasco coletor, adicionou-se $0,50 \mathrm{~mL}$ de solução de $\mathrm{NaOH} \mathrm{0,1} \mathrm{M} \mathrm{e} \mathrm{fechou-se} \mathrm{com} \mathrm{tampa} \mathrm{de} \mathrm{vidro} \mathrm{esmerilhado,} \mathrm{envolta} \mathrm{por} \mathrm{película} \mathrm{de} \mathrm{teflon.}$ Adicionou-se ao balão, volume de $1,00 \mathrm{~mL}$ de amostras, $100 \mu \mathrm{L}$ de solução de ácido crotônico (3500 mg. $\mathrm{L}^{-1}$ ) e $100 \mu \mathrm{L}$ de solução de ácido sulfúrico 6,0 M, e fechou-se com tampa de vidro esmerilhado envolta em película de teflon. Imediatamente, um tampão de algodão hidrófilo foi colocado no frasco lavador de vapores, ao qual adicionou-se $0,40 \mathrm{~mL}$ de solução de $\mathrm{NaOH}$ 0,1 M.

O aquecimento máximo da manta permitiu que o final da destilação fosse atingido após cerca de 3 minutos, quando 1,00 mL de amostra foi destilada, constatando-se pela 
ausência de ebulição do líquido remanescente (ácido sulfúrico) e pela presença de resíduos escuros não voláteis.

O volume de amostra injetado no cromatógrafo foi de $1,0 \mu \mathrm{L}$.

\subsection{Exames físicos e microbiológicos}

\subsubsection{Volume da manta e descarte de lodo}

Foi adotada a prática de descarte do lodo ao final de cada TDH ou quando do comprometimento da qualidade do efluente do segundo reator devido ao arraste de sólidos, ocasionado pelo crescimento da manta de lodo e conseqüente enchimento do reator.

Nos primeiros 65 dias de operação, considerando o período de partida, com concentração média de SST de $5240 \mathrm{mg}$. $\mathrm{L}^{-1}$ e TDH de $62 \mathrm{~h}$, no ensaio 1 do experimento, na troca de TDH para $31 \mathrm{~h}$, no primeiro reator, observou-se o crescimento da manta nos dois reatores, atingindo o sedimentador, com acúmulo contínuo de sólidos. Nesta condição não foi observado o comprometimento da qualidade do efluente do segundo reator pelo arraste de sólidos. Antes da diminuição do TDH foi efetuado o $1^{\mathrm{o}}$ descarte de lodo do primeiro e segundo reatores, sendo o volume descartado de 16,0 e 5,0 L de lodo, respectivamente.

No ensaio 2 do experimento com concentração média de SST de 5000 mg.L $\mathrm{L}^{-1}$ e TDH de $31 \mathrm{~h}$, no primeiro reator, aos 107 dias de operação observou-se o crescimento da manta de lodo, a qual atingiu o sedimentador e ocasionou o comprometimento da qualidade do efluente do segundo reator. Assim, procedeu-se o $2^{\circ}$ descarte de lodo da manta dos reatores. O volume descartado do primeiro e segundo reatores foi de 16,0 e 5,5 L de lodo, respectivamente. Aos 137 dias de operação, ainda com TDH de 31 h, foi necessário o $3^{\circ}$ descarte de lodo da manta do primeiro e segundo reatores sendo, respectivamente, o volume descartado de 24,0 e 5,5 L.

Nesta etapa da operação, com TDH de 31 h, devido ao constante arraste e acúmulo de sólidos do primeiro para o segundo reator, ocorreu entupimento na tubulação de entrada do segundo reator. A desobstrução da tubulação ocasionou maior velocidade hidráulica do efluente na entrada do segundo reator e, conseqüentemente, o revolvimento da manta de lodo. O volume de sólidos acumulado no sedimentador foi removido com seringa e reintroduzido no reator.

Antes do início do ensaio 3, com TDH de $16 \mathrm{~h}$, os reatores foram operados por um período de 24 dias, para adaptação do sistema ao aumento da carga orgânica, com TDH de 18 h. Antes da troca de TDH para 16 h, no primeiro reator, aos 171 dias de operação, foi 
efetuado o $4^{\circ}$ descarte de lodo da manta dos reatores. Os volumes descartados no primeiro e segundo reatores foram, respectivamente, de 10,0 e 2,0 L.

No final do ensaio 3, término da operação do sistema, aos 210 dias de operação, foi realizado o $5^{\circ}$ descarte da manta de lodo dos reatores. $\mathrm{O}$ volume de lodo descartado do primeiro reator foi de 20,0 L e do segundo reator de 3,0 L. Neste ensaio a concentração média de SST foi de $5490 \mathrm{mg} \cdot \mathrm{L}^{-1}$.

Na Tabela 3.5 estão discriminados os dias nos quais foram realizados os descartes de lodo.

Tabela 3.5. Relação dos dias de operação nos quais foram realizados descartes de lodo da manta dos reatores UASB.

\begin{tabular}{|c|c|c|c|c|}
\hline \multirow[t]{4}{*}{ Reator } & \multicolumn{4}{|c|}{ Dias de operação } \\
\hline & \multirow{2}{*}{$\begin{array}{l}\text { Ensaio } 1 \\
\text { TDH (h) }\end{array}$} & \multirow{2}{*}{$\begin{array}{l}\text { Ensaio } 2 \\
\text { TDH (h) }\end{array}$} & \multirow{2}{*}{\multicolumn{2}{|c|}{$\begin{array}{l}\text { Ensaio } 3 \\
\text { TDH (h) }\end{array}$}} \\
\hline & & & & \\
\hline & $62 \mathrm{r} 1 \quad 16 \mathrm{r} 2$ & $31 \mathrm{r} 1$ & $16 \mathrm{r} 1$ & $4 \mathrm{r} 2$ \\
\hline \multirow[t]{2}{*}{$\mathrm{r} 1$} & \multirow[t]{2}{*}{65} & 107 & \multicolumn{2}{|c|}{171} \\
\hline & & 137 & \multicolumn{2}{|c|}{210} \\
\hline \multirow[t]{2}{*}{$\mathrm{r} 2$} & \multirow[t]{2}{*}{65} & 107 & \multicolumn{2}{|c|}{171} \\
\hline & & 137 & \multicolumn{2}{|c|}{210} \\
\hline
\end{tabular}

\subsubsection{Exames microbiológicos}

$\mathrm{Na}$ caracterização morfológica das bactérias e arqueas metanogênicas presentes no lodo granulado dos reatores UASB foi utilizada a microscopia óptica de contraste de fase e fluorescência, através de microscópio Olympus modelo BH2. As amostras para realização dos exames microscópicos foram coletadas da região inferior, intermediária e superior da manta de lodo do primeiro reator (tomadas 1, 3 e 5) e do segundo reator (tomadas 1, 2 e 3), no início e ao final dos ensaios 1, 2 e 3 do experimento. As amostras foram coletadas instantes antes da realização dos exames e maceradas para preparação das lâminas. Após a preparação, as foram levadas ao microscópio para observação.

As amostras do lodo de descarte também foram coletadas para os exames microscópicos. 
Para estudo da distribuição espacial das morfologias, no interior, ao longo da parede do grânulo, foi utilizada a microscopia eletrônica de varredura (MEV), por meio de microscópio eletrônico digital Zeiss DSM-960.

Para o exame de microscopia eletrônica de varredura as amostras foram previamente preparadas, conforme metodologia descrita por Oliveira (1997). Inicialmente, as amostras de lodo para exame foram lavadas em proveta com água de torneira para retirada de sólidos finos dispersos e a separação dos grânulos.

Em seguida foram colocados alguns grânulos inteiros em tubo de ensaio de $10 \mathrm{~mL}$, submersos por solução tampão fosfato com concentração $0,1 \mathrm{M}(\mathrm{pH}=7,3)$ contendo $2,5 \%$ de glutaraldeído durante 12 horas e resfriado a $4^{\circ} \mathrm{C}$. Depois de retirado o glutaraldeído, as amostras fixadas foram submetidas a três lavagens com solução tampão fosfato por 10 minutos. Após a lavagem com solução tampão, as amostras foram desidratadas com soluções de etanol a $50 \%, 70 \%, 80 \%, 90 \%, 95 \%$ e $100 \%$, mantendo-se os grânulos imersos em cada uma das soluções por 10 minutos, repetindo-se o último passo (etanol 100\%) por três vezes. Após a desidratação, os grânulos foram imersos, duas vezes, por 30 segundos em solução de hexametildesilazane (HMDS) e em seguida secos ao ar.

Terminada a secagem, os grânulos foram seccionados ao meio com auxílio de agulha e lâmina e dispostos sobre suportes de alumínio, fixados com fita adesiva dupla face e levados para metalização no Laboratório de Microscopia Eletrônica de Varredura - IQSC/USP, com cobertura de fina camada de ouro, para tornarem-se materiais eletricamente condutivos. Então, os suportes com as amostras, foram levados ao MEV para o exame microbiológico e realização de eletromicrografias.

\subsection{Operações de manutenção da unidade experimental}

O sistema foi monitorado diariamente. A vazão afluente foi verificada três vezes por semana por meio de proveta e cronômetro e, diariamente, pelo volume de afluente bombeado para o reator. As mangueiras de silicone foram periodicamente pressionadas para desprendimento de sólidos finos aderidos à parede. Este procedimento evitou possíveis entupimentos e diminuição da vazão. As mangueiras foram substituídas a cada troca de TDH.

Os tanques de armazenamento de afluente e efluente foram lavados diariamente, juntamente com o reabastecimento do substrato para alimentação dos reatores.

No ensaio 1, com TDH de $62 \mathrm{~h}$ no primeiro reator, houve formação de fina camada de sólidos no topo dos reatores. Esta camada de sólidos foi removida, diluída com efluente para 
que não ocasionasse problemas de entupimento das mangueiras e introduzida no segundo reator. Com o crescimento da manta de lodo e enchimento dos reatores, sólidos finos depositavam-se nos sedimentadores e foram retirados periodicamente com auxílio de seringa e espátula, retornando-os para os reatores.

Com a diminuição do TDH para $31 \mathrm{~h}$ no primeiro reator, ensaio 2 , houve formação de camadas mais espessas de sólidos arrastados para os sedimentadores. Estas camadas de sólidos ocasionavam selamento nas saídas dos separadores e nos sedimentadores, muitas vezes impedindo a saída do efluente, principalmente no primeiro reator, por períodos curtos. No rompimento desta camada havia maior arraste de sólidos, o que provocava entupimentos na mangueira de entrada do segundo reator.

Para evitar o transbordamento do efluente dentro da câmara foi instalado funil plástico na saída do primeiro reator. A este funil foi conectada mangueira de silicone e ligada a balde plástico. Este procedimento, além de evitar o derrame do efluente no interior da câmara, permitiu medir o volume deslocado para fora do segundo reator.

Com o crescimento da manta dos reatores os entupimentos tornaram-se constantes, impedindo a realização das análises. $\mathrm{O}$ volume de efluente deslocado para fora do segundo reator, nos períodos noturnos, foi em média de $15 \mathrm{~L}$ com duração de até 8 dias consecutivos.

Com o aumento da produção de gás devido ao aumento da carga orgânica, no ensaio 2 do experimento, o volume do reator sofria abaixamento, em torno de $5 \mathrm{~cm}$, verificado no topo do primeiro reator sempre que grandes volumes de gases foram produzidos no reator. Como conseqüência ocorreram entupimentos freqüentes da mangueira de saída de gases do reator, as quais foram retiradas e lavadas. Com o aumento do headspace do reator, até o limite do tubo de acrílico com o separador, não foram mais observados entupimentos freqüentes.

No ensaio 3, com TDH de $16 \mathrm{~h}$ no primeiro reator, os problemas de entupimentos continuaram pelo arraste de sólidos para os sedimentadores. Freqüentemente foi retirada a camada de sólidos finos formada no topo dos reatores para que não houvesse comprometimento do efluente final. 


\section{RESULTADOS E DISCUSSÃO}

Neste item são apresentados os resultados obtidos nos três ensaios do experimento, os quais compreenderam o TDH de $62 \mathrm{~h}$ (ensaio 1), TDH de $31 \mathrm{~h}$ (ensaio 2) e TDH $16 \mathrm{~h}$ (ensaio 3), no primeiro reator. A concentração de SST do afluente na alimentação do primeiro reator nos ensaios foi em torno de $5000 \mathrm{mg} \cdot \mathrm{L}^{-1}$.

\subsection{Exames físicos e determinações de constituintes orgânicos e inorgânicos não metálicos}

As variações observadas nos valores médios das variáveis analisadas nos afluentes, dentro de cada ensaio, podem ser atribuídas às alterações da composição das águas residuárias, devido às dificuldades de diluição, no preparo do substrato, para obtenção das concentrações desejadas. Também pela mudança das características do esterco bruto coletado ao longo do experimento.

No período de partida dos reatores, com TDH de $62 \mathrm{~h}$ no primeiro reator e SST em torno de $2000 \mathrm{mg} . \mathrm{L}^{-1}$, com tempo de operação de 19 dias, o sistema apresentou eficiência de remoção de $\mathrm{DQO}_{\text {total, }}$ no primeiro e segundo reatores, de 94 e 38\%, respectivamente, com eficiência do sistema de $96 \%$. Os dados não foram apresentados nas tabelas de resultados para obtenção dos valores médios dos ensaios. Da mesma forma, não foram considerados os dados obtidos na mudança para o ensaio 2 (TDH 31 h) e 3 (TDH 16 h), quando o primeiro reator foi operado por 21 e 24 dias com TDH intermediário de 46 e 18 h apresentando valores médios de remoção de $\mathrm{DQO}_{\text {total }}$ de $95 \%$ e $80 \%$, respectivamente. O segundo reator apresentou eficiência de remoção de $\mathrm{DQO}_{\text {total }}$ de $36 \%$ e $37 \%$, sendo a eficiência do sistema de $96 \%$ e $88 \%$. Isto porque determinariam valores de coeficiente de variação (CV) muitos altos, não refletindo o desempenho dos reatores nestas condições operacionais. 


\subsubsection{Partida do Sistema}

As condições impostas ao primeiro e segundo reatores no início de suas operações: afluentes com valores médios de 1460 e $90 \mathrm{mg} . \mathrm{L}^{-1}$ de SST, 4625 e $242 \mathrm{mg} . \mathrm{L}^{-1}$ de DQO, TCOV médias de 1,79 e $0,36 \mathrm{~kg} \mathrm{DQO}_{\text {total }} \cdot \mathrm{m}^{-3} \cdot \mathrm{d}^{-1}$, TCL de 0,10 e $0,04 \mathrm{~kg} \mathrm{DQO}_{\text {total }} \cdot \mathrm{kg} \mathrm{SSV}$ ${ }^{1}$.dia ${ }^{-1}$, respectivamente, lodo de inóculo granulado com SV de 41000 mg.L-1 e sem recirculação do efluente, propiciaram partida rápida do sistema.

Após 19 dias do início da operação, observou-se, no primeiro reator, os valores de DQO e SST do efluente constantes, na faixa de 242 e $0,07 \mathrm{mg} . \mathrm{L}^{-1}$, respectivamente, com eficiências de remoção superiores a 90\% (Figuras 4.1, 4.2, 4.3 e 4.4), concentrações de metano no biogás acima de $70 \%$ em ambos os reatores, a concentração média de AVT tendendo a estabilizar-se em valores inferiores a $80 \mathrm{mg} . \mathrm{L}^{-1}$ (Figura 4.5) e $\mathrm{pH}$ dos efluentes mantendo-se acima de 7,0.

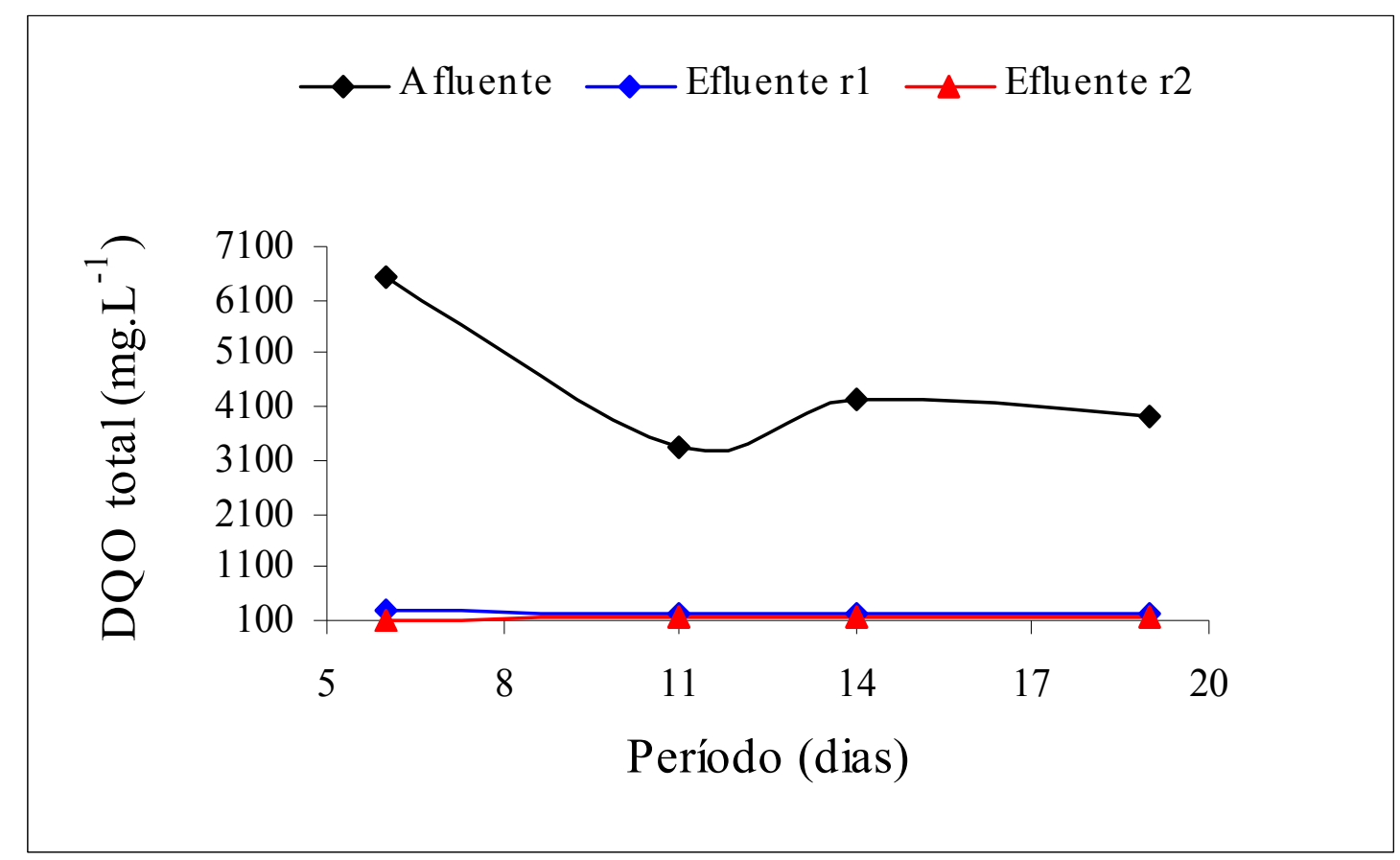

Figura 4.1. Concentrações de $\mathrm{DQO}_{\text {total }}$ obtidas na partida do sistema em dois estágios. 


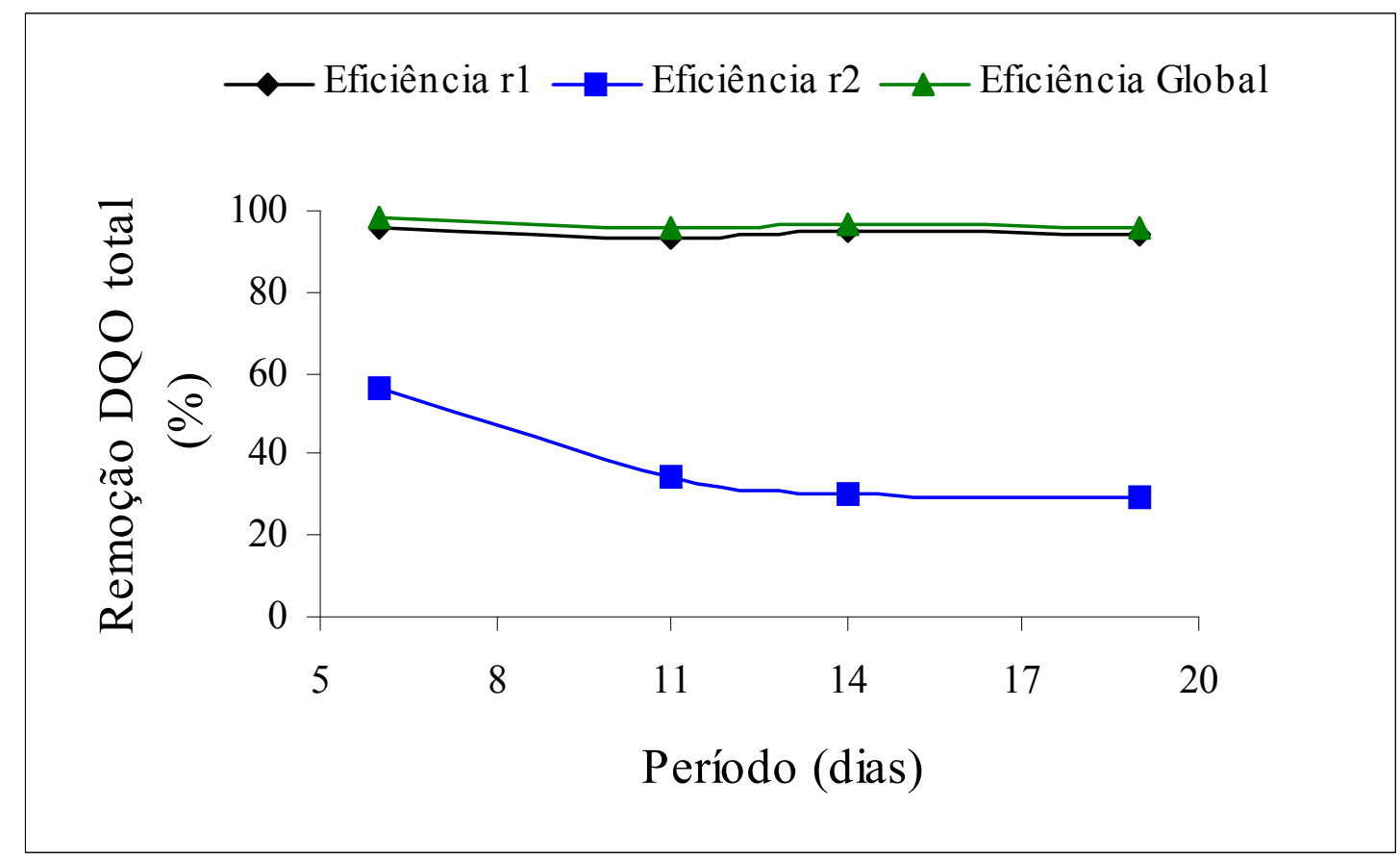

Figura 4.2. Eficiências de remoção de $\mathrm{DQO}_{\text {total }}$ obtidas na partida do sistema em dois estágios.

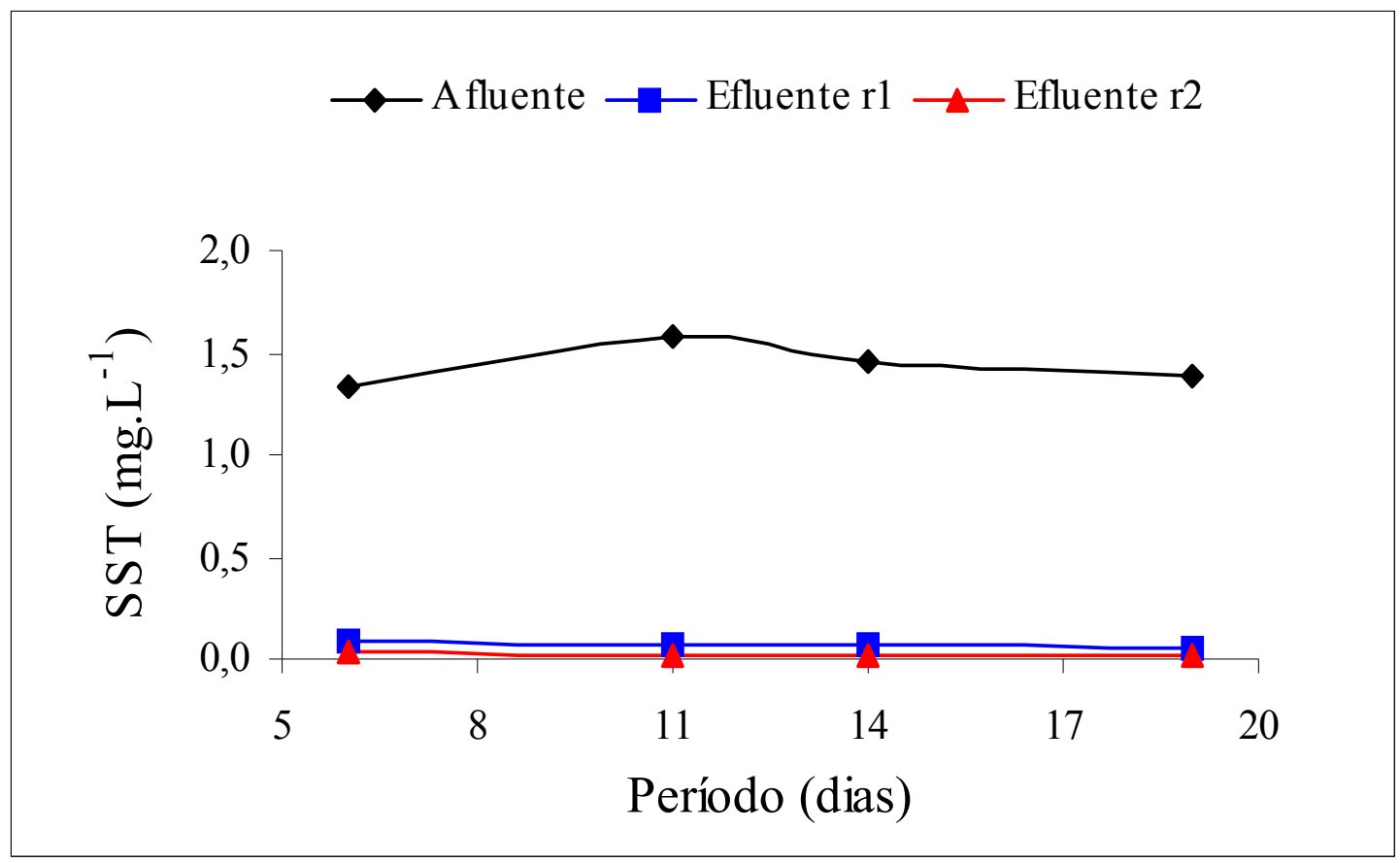

Figura 4.3. Concentrações de sólidos suspensos totais (SST) obtidas na partida do sistema em dois estágios. 


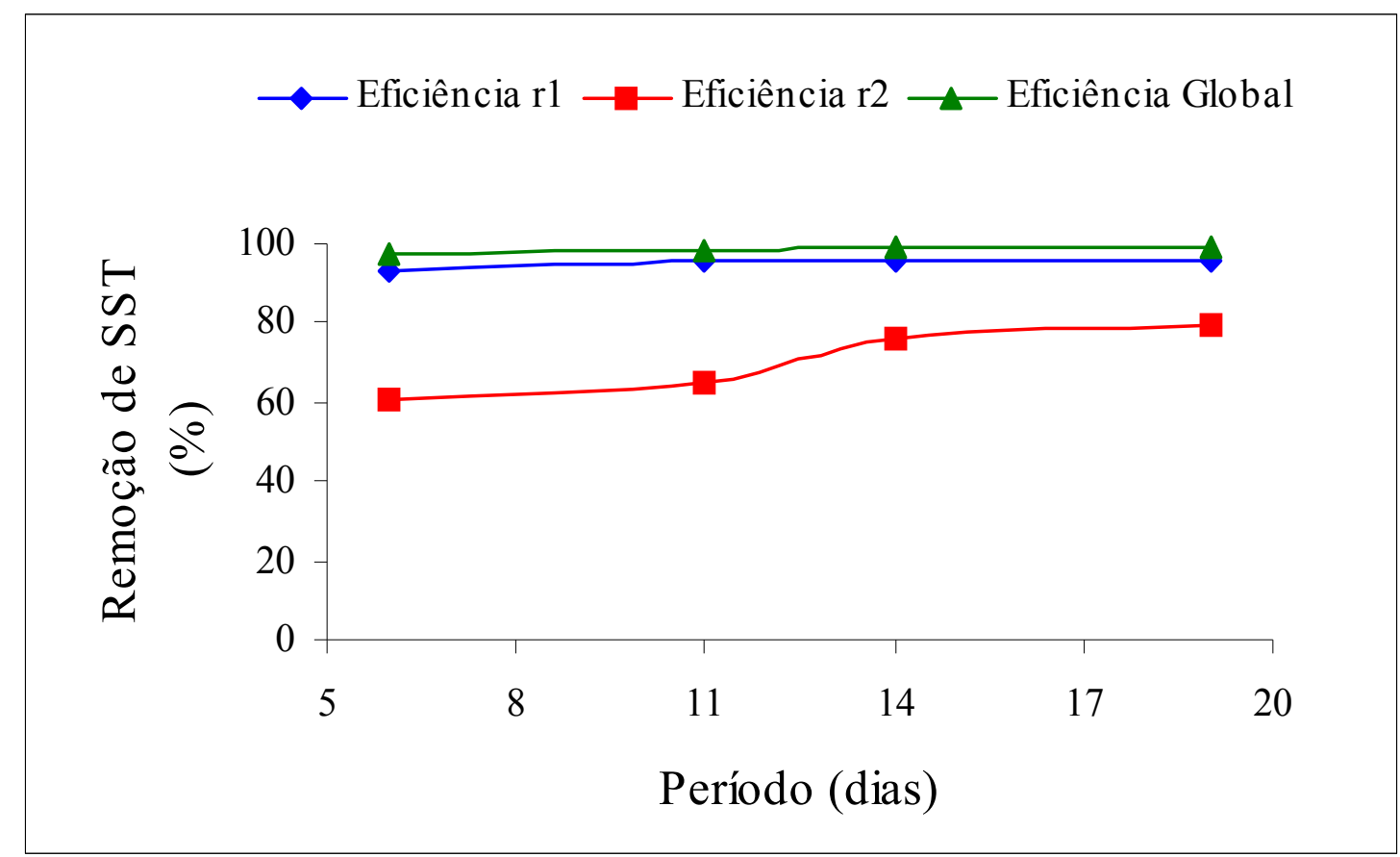

Figura 4.4. Eficiências de remoção de sólidos suspensos totais (SST) obtidas na partida do sistema em dois estágios.

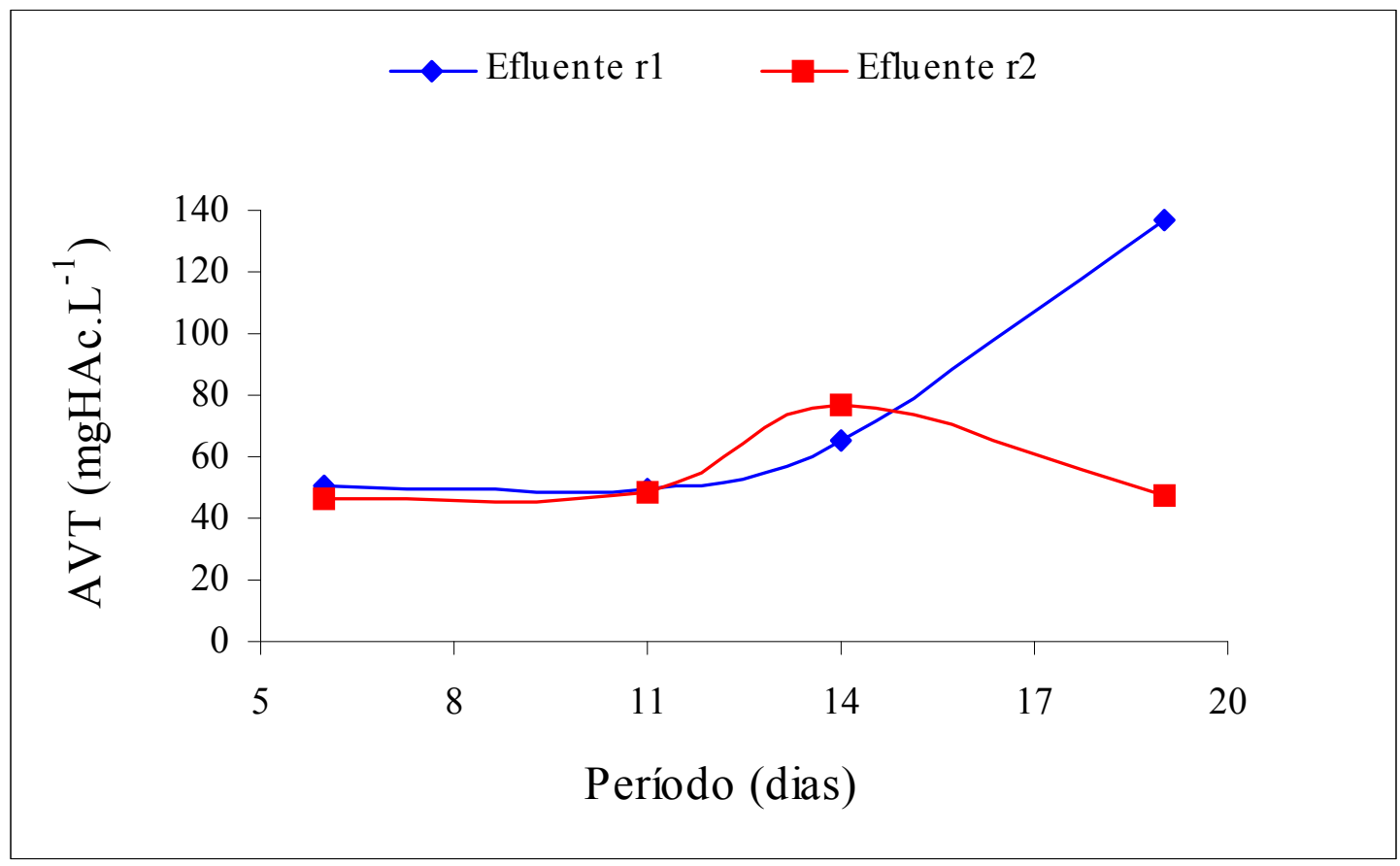

Figura 4.5. Concentrações de ácidos voláteis totais (AVT) nos efluentes do primeiro e segundo reatores na partida do sistema em dois estágios. 
A partida rápida com manutenção de lodo granulado pode ser atribuída inicialmente ao lodo de inóculo granulado e adaptado ao efluente tratado, proveniente de reator UASB tratando águas residuárias de suínos, com concentração de SV de 41000 mg.L ${ }^{-1}$ correspondendo a 90\% dos ST. De acordo com Schmidt e Ahring (1996), o conteúdo mineral do lodo pode variar de 10 a $90 \%$ do seu peso seco.

\subsubsection{Temperatura da câmara com os reatores UASB}

Na Figura 4.6 estão apresentados os valores das temperaturas máximas e mínimas do ar, dentro da câmara contendo os reatores UASB, obtidos durante a operação do sistema em dois estágios, respectivamente, nos ensaios 1, 2 e 3 do experimento.

No início do ensaio 1 com TDH de $62 \mathrm{~h} \mathrm{e} 16 \mathrm{~h}$, no primeiro e segundo reatores, respectivamente, o sistema foi operado com controle da temperatura por meio de termostato. Observaram-se temperaturas na faixa de $27,1^{\circ} \mathrm{C}$ a $30,4^{\circ} \mathrm{C}$.

A partir do $44^{\circ}$ dia foi instalado no interior da câmara um termômetro de máxima e mínima, o que permitiu controle mais adequado da temperatura na faixa de 25 a $30^{\circ} \mathrm{C}$. As temperaturas máximas situaram-se na faixa de $26^{\circ} \mathrm{C}$ a $29^{\circ} \mathrm{C}$ e mínimas de $20^{\circ} \mathrm{C}$ a $25^{\circ} \mathrm{C}$, no ensaio 1.

No ensaio 2, com TDH de $31 \mathrm{~h}$ no primeiro reator, observaram-se aumentos nas temperaturas máximas e mínimas, respectivamente, com valores de $25^{\circ} \mathrm{C}$ a $30^{\circ} \mathrm{C}$ e $21^{\circ} \mathrm{C}$ a $28^{\circ} \mathrm{C}$.

No ensaio 3, com TDH de $16 \mathrm{~h}$ no primeiro reator, as temperaturas máximas e mínimas observadas foram, respectivamente, de $29^{\circ} \mathrm{C}$ a $31^{\circ} \mathrm{C}$ e $25^{\circ} \mathrm{C}$ a $30^{\circ} \mathrm{C}$. Isto pode ser explicado pelo aumento da temperatura ambiente no período de operação, nos ensaios 2 e 3 , e conseqüente elevação dos valores da temperatura no interior da câmara. 


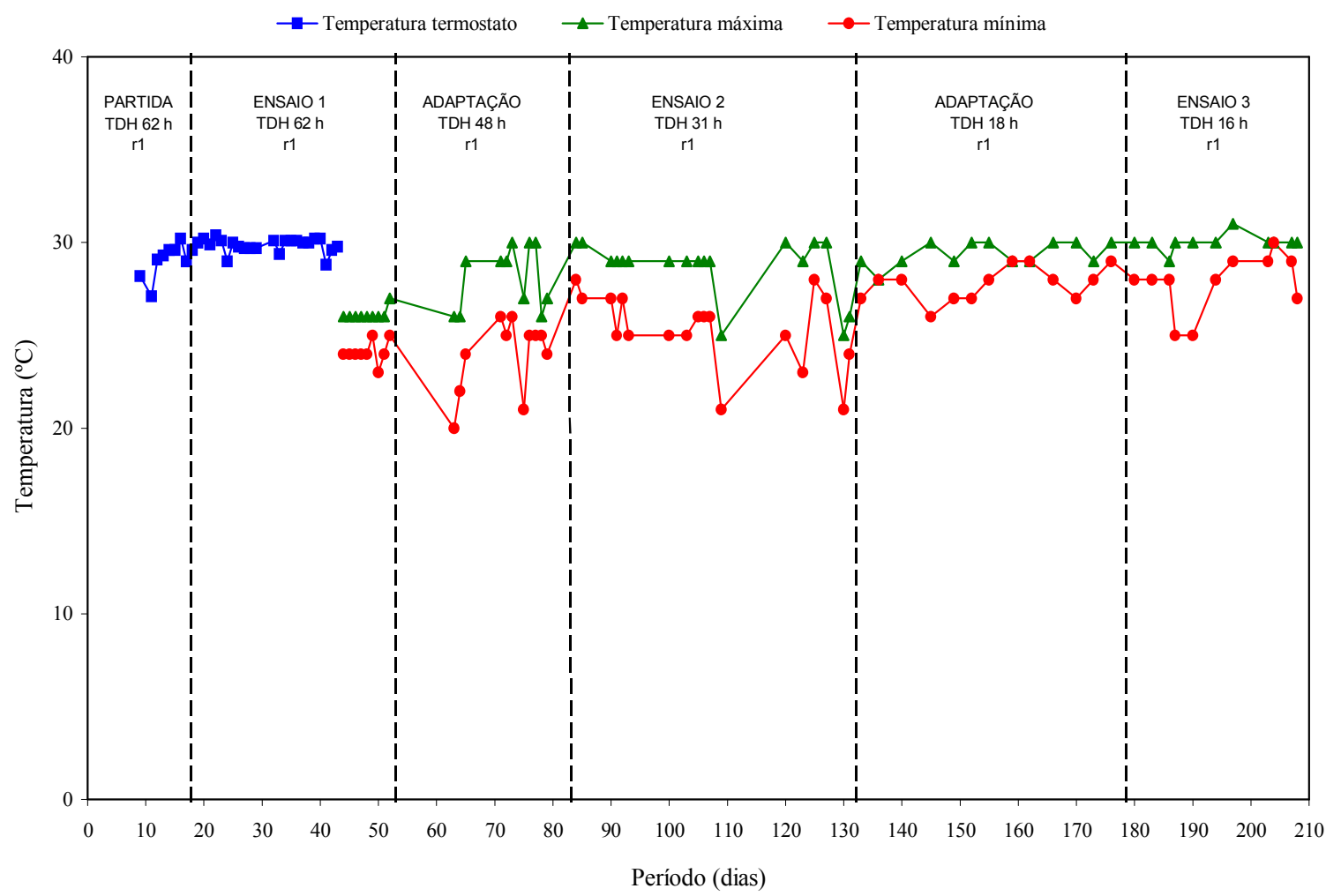

Figura 4.6. Leituras das temperaturas máxima e mínima do ar durante a operação dos reatores nos ensaios 1,2 e 3 do experimento.

\subsubsection{Demanda química de oxigênio}

$\mathrm{Na}$ Tabela 4.1 estão apresentados os resultados médios e os coeficientes de variação (CV) da DQO $\mathrm{Dtatal}_{\mathrm{e}} \mathrm{e}_{\text {dissolvida }}$ do afluente e efluente, eficiência de remoção de DQO (E) e taxa de carregamento orgânico volumétrico (TCOV) em relação a $\mathrm{DQO}_{\text {total }} \mathrm{e}$ dissolvida, obtidos durante a operação do sistema em dois estágios nos ensaios 1, 2 e 3 do experimento.

A DQO ${ }_{\text {total }}$ do afluente apresentou valores médios semelhantes de $11740 \mathrm{mg} . \mathrm{L}^{-1} \mathrm{e}$ $11292 \mathrm{mg} . \mathrm{L}^{-1}$, nos ensaios 1 e 2, respectivamente. No ensaio 3 houve aumento do valor médio de $\mathrm{DQO}_{\text {total }}$ para $12306 \mathrm{mg} . \mathrm{L}^{-1}$, podendo-se atribuir ao lote de esterco bruto utilizado para alimentação dos reatores, o qual foi coletado no final do ciclo dos animais em confinamento, apresentando-se mais consistente e menos diluído que o dos lotes anteriores. 
Tabela 4.1. Valores médios e coeficiente de variação (CV) da $\mathrm{DQO}_{\text {total }} \mathrm{e}_{\text {dissolvida }}$ do afluente e efluentes, eficiência de remoção de DQO (E) e taxa de carregamento orgânico volumétrico (TCOV),

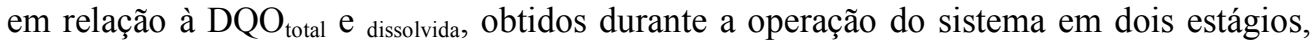
primeiro(r1) e segundo (r2) reator, nos ensaios 1,2 e 3.

\begin{tabular}{|c|c|c|c|c|c|c|c|c|c|c|c|c|c|c|c|c|}
\hline \multirow[t]{3}{*}{ Ensaio } & \multirow{2}{*}{\multicolumn{2}{|c|}{$\begin{array}{c}\text { TDH } \\
\text { (h) }\end{array}$}} & \multicolumn{5}{|c|}{ DQO $_{\text {Total }}$} & \multicolumn{7}{|c|}{ DQO $_{\text {dis. }}$} & \multicolumn{2}{|c|}{ TCOV } \\
\hline & & & \multirow[t]{2}{*}{ afl. } & \multicolumn{2}{|c|}{ efluente } & \multicolumn{3}{|c|}{ E $(\%)$} & \multirow[t]{2}{*}{ afl. } & \multicolumn{2}{|c|}{ efluente } & \multicolumn{3}{|c|}{ E (\%) } & \multirow[t]{2}{*}{$*$ total } & \multirow[t]{2}{*}{ * dissolv } \\
\hline & $\mathrm{r} 1$ & $\mathrm{r} 2$ & & $\mathrm{r} 1$ & $\mathrm{r} 2$ & $\mathrm{r} 1$ & $\mathrm{r} 2$ & global & & $\mathrm{r} 1$ & $\mathrm{r} 2$ & $\mathrm{r} 1$ & $\mathrm{r} 2$ & global & & \\
\hline 1 & 62 & 16 & 11740 & 1681 & 574 & 86 & 59 & 95 & 3476 & 501 & 395 & 85 & 22 & 88 & 4,55 & 1,35 \\
\hline 2 & 31 & 8 & 11292 & 1569 & 861 & 86 & 43 & 92 & 3050 & 487 & 415 & 84 & 14 & 86 & 8,75 & 2,36 \\
\hline 3 & 16 & 4 & 12306 & 3365 & 2581 & 73 & 23 & 79 & 3140 & 832 & 740 & 73 & 11 & 76 & 18,65 & 4,76 \\
\hline $\mathrm{C}$ & 62 & 16 & 11,9 & 65,4 & 19,9 & 11,6 & 28,8 & 1,1 & 13,2 & 24,8 & 18,7 & 11,8 & 77,3 & 3,4 & 15,4 & 17,1 \\
\hline V & 31 & 8 & 12,4 & 30,0 & 25,2 & 5,8 & 32,6 & 2,2 & 10,5 & 10,5 & 10,6 & 6,0 & 100,0 & 2,3 & 16,0 & 13,5 \\
\hline$(\%)$ & 16 & 4 & 8,8 & 15,0 & 16,5 & 5,5 & 13,0 & 5,1 & 16,1 & 6,1 & 7,4 & 6,8 & 72,7 & 3,9 & 8,74 & 15,97 \\
\hline
\end{tabular}

Unidades: DQO: mg. $\mathrm{L}^{-1}, \mathrm{TCOV}: \mathrm{kg}$ DQO* $\mathrm{m}^{3} \mathrm{~d}^{-1}$

Em todos os ensaios, as médias situaram-se dentro do estipulado na metodologia. $\mathrm{Na}$ Figura 4.7 estão apresentados os resultados da $\mathrm{DQO}_{\text {total }}$ obtidos nos ensaios. Os coeficientes de variação do afluente para os ensaios 1,2 e 3 foram, respectivamente, de $11,9 \% ; 12,4 \%$ e $8,8 \%$.

Os valores médios da $\mathrm{DQO}_{\text {dissolvida }}$ do afluente foram de $3476 \mathrm{mg} \cdot \mathrm{L}^{-1}, 3050 \mathrm{mg} . \mathrm{L}^{-1} \mathrm{e}$ $3140 \mathrm{mg} . \mathrm{L}^{-1}$ nos ensaios 1,2 e 3 , respectivamente, seguindo variação similar à $\mathrm{DQO}_{\text {total }}$ afluente. Os resultados da $\mathrm{DQO}_{\text {dissolvida }}$ e devido à fração de sólidos suspensos obtidos nos ensaios do experimento estão apresentados na Figura 4.8 e 4.9 , respectivamente. 


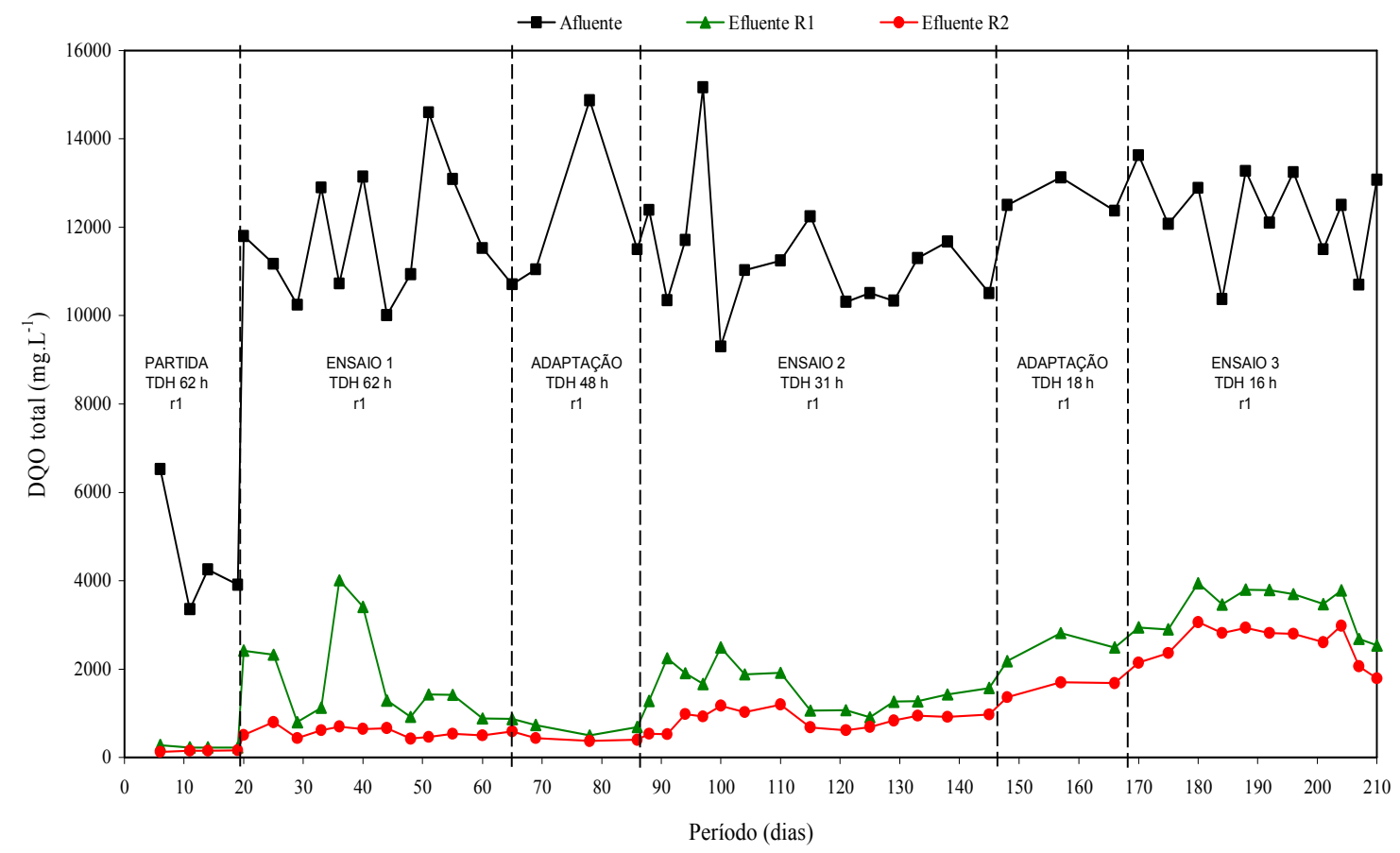

Figura 4.7. Concentrações de $\mathrm{DQO}_{\text {total }}$ obtidas no afluente e efluentes do primeiro e segundo reatores nos ensaios 1,2 e 3 .

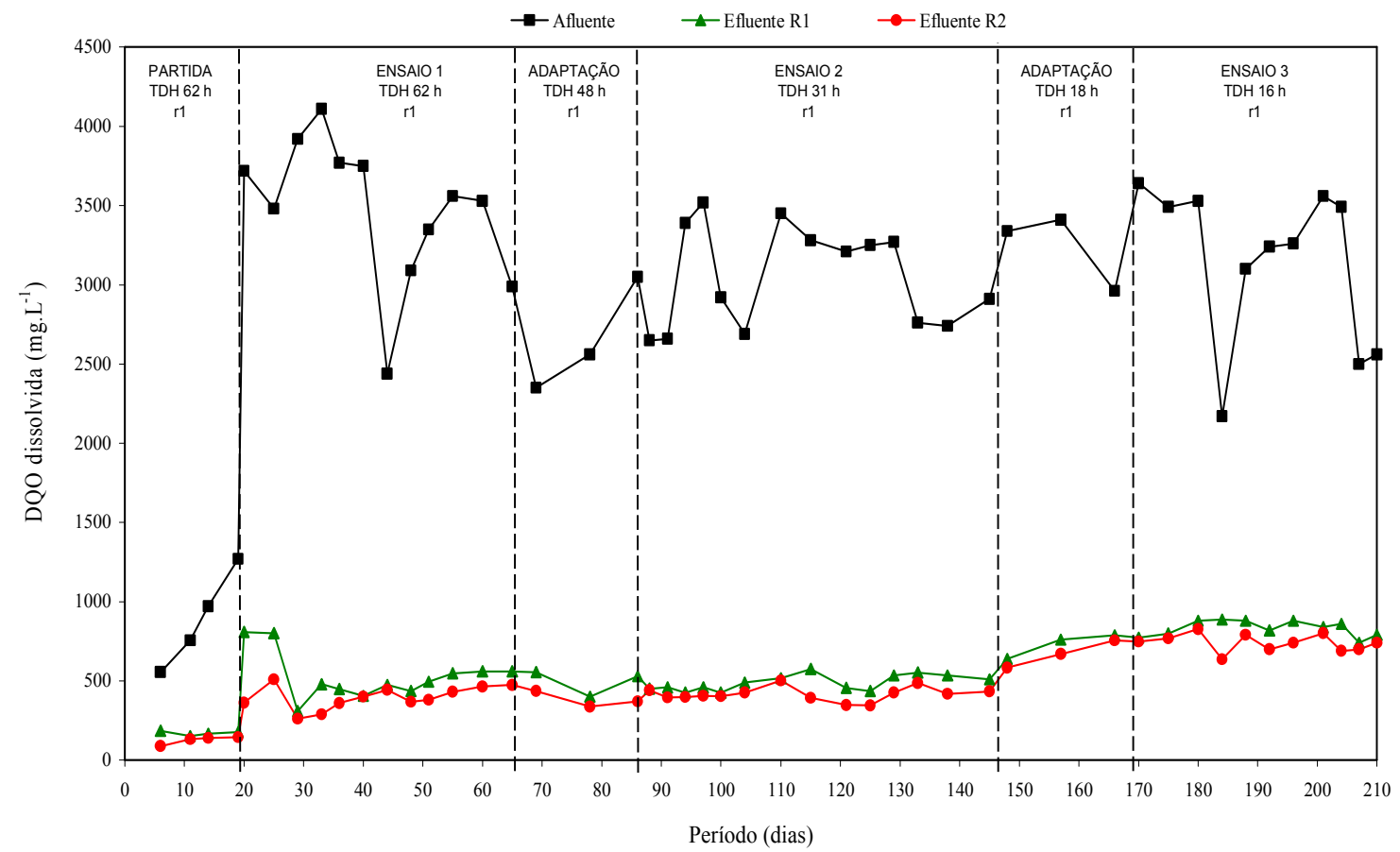

Figura 4.8. Concentrações de $\mathrm{DQO}_{\text {dissolvida }}$ obtidas no afluente e efluentes do primeiro e segundo reatores nos ensaios 1,2 e 3 . 


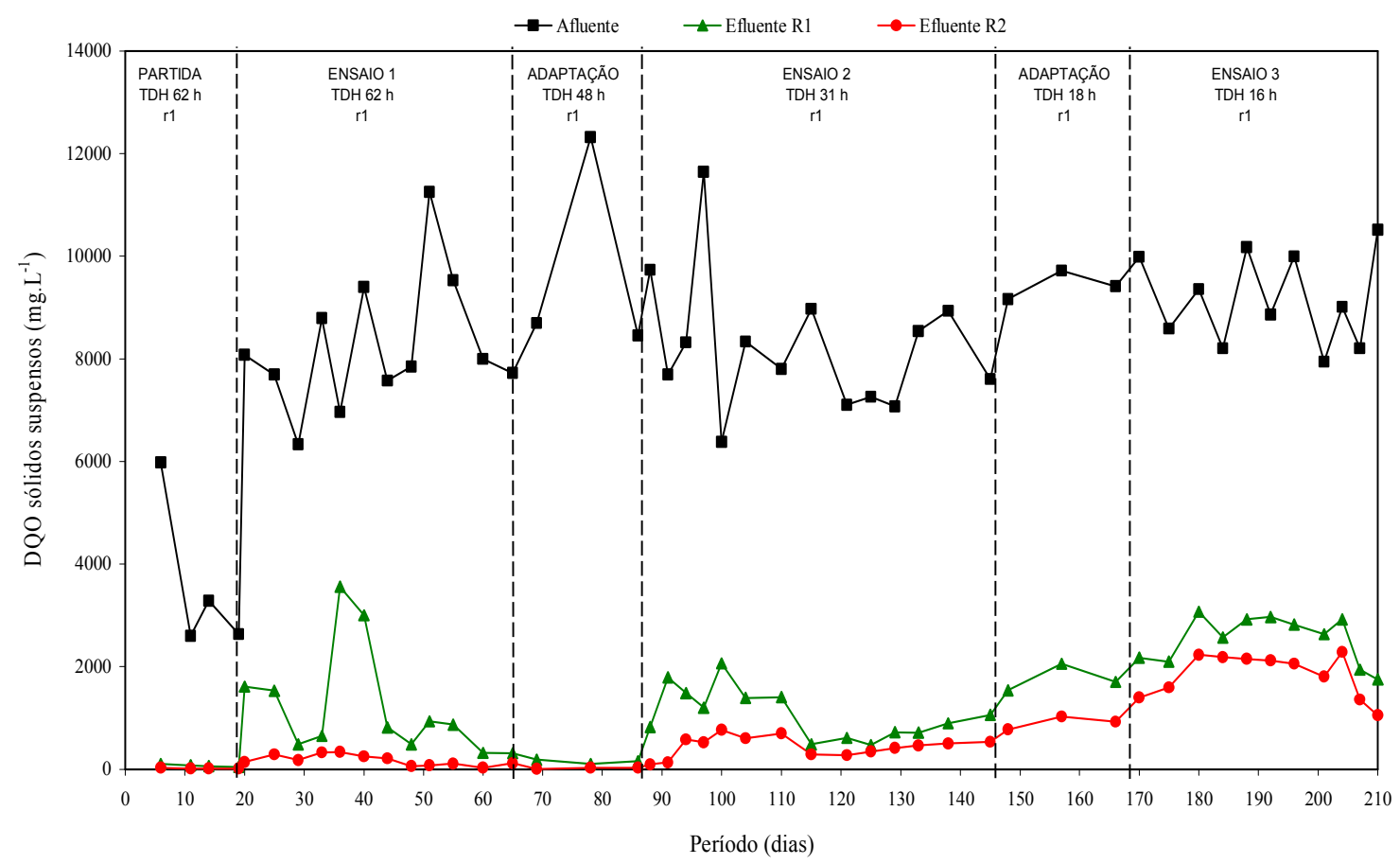

Figura 4.9. Concentrações de DQO devido à fração de sólidos suspensos obtidas no afluente e efluentes do primeiro e segundo reatores nos ensaios 1,2 e 3 .

A DQO devido à fração de sólidos suspensos (SS), resultante da diferença entre a

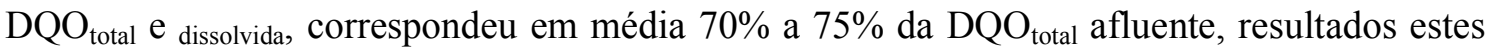
similares aos obtidos por Oliveira (1997), que em trabalho realizado com águas residuárias de suinocultura, em reator UASB, obteve DQO da fração de sólidos suspensos (SS) entre 66\% a $80 \%$.

Nos ensaios 1 e 2, a DQO ${ }_{\text {total }}$ do efluente do primeiro reator permaneceu praticamente constante, apresentando valores médios semelhantes de 1681 mg.L ${ }^{-1}$ e 1569 mg.L $\mathrm{L}^{-1}$, respectivamente, e eficiências de remoção de $86 \%$ para ambos os ensaios. No ensaio 3 houve aumento do valor médio para $3365 \mathrm{mg} . \mathrm{L}^{-1}$, resultando em queda da eficiência de remoção para $73 \%$. A queda de eficiência foi devida ao aumento da taxa de carregamento orgânico no primeiro reator, de 4,55 a $18,65 \mathrm{~kg} \mathrm{DQO}_{\text {total }} \cdot \mathrm{m}^{-3} \cdot \mathrm{dia}^{-1}$, impondo sobrecarga orgânica (OLIVEIRA, 1997). Ainda, segundo o autor, essa redução de eficiência pode estar associada à elevação da CHV (carga hidráulica volumétrica) e aumento da produção de biogás e conseqüente aumento do arraste de sólidos no sistema, o qual pode ser confirmado observando-se o aumento da participação da DQO devido à fração de sólidos suspensos na 
$\mathrm{DQO}_{\text {total }}$ dos efluentes do primeiro e segundo reatores. Sendo assim, a maior eficiência de remoção de $\mathrm{DQO}_{\text {total }}$ obtida no sistema foi verificada nos ensaios 1 e 2 .

Os valores médios de $\mathrm{DQO}_{\text {dissolvida }}$ do efluente decresceram, respectivamente, de 501 mg. $\mathrm{L}^{-1}$ para $487 \mathrm{mg} . \mathrm{L}^{-1}$, ensaios 1 e 2, e apresentou aumento médio para $832 \mathrm{mg} . \mathrm{L}^{-1}$, no ensaio 3.

No segundo reator, nos ensaios 1 e 2, com $\mathrm{DQO}_{\text {total }}$ do efluente com valores médios de $574 \mathrm{mg} . \mathrm{L}^{-1}$ e $861 \mathrm{mg} . \mathrm{L}^{-1}$ houve queda da eficiência de remoção de $59 \%$ para $43 \%$. No ensaio 3 houve aumento do valor médio da $\mathrm{DQO}_{\text {total }}$ do efluente para $2581 \mathrm{mg} . \mathrm{L}^{-1}$ e conseqüente queda da eficiência de remoção para $23 \%$.

Com o aumento da taxa de carregamento orgânico de 2,55 a 21,03 kg DQO total. $\mathrm{m}^{-3}$. $\mathrm{dia}^{-}$ 1 , o efluente do segundo reator apresentou aumento nos valores médios de $\mathrm{DQO}_{\text {dissolvida }}$ de 395 mg. $\mathrm{L}^{-1}$ para $740 \mathrm{mg} . \mathrm{L}^{-1}$, resultando em queda da eficiência de remoção do sistema de 88 para $76 \%$. Para a $\mathrm{DQO}_{\text {total }}$ a diminuição na eficiência de remoção do sistema foi de $95 \%$ para $79 \%$.

Esses resultados são similares aos obtidos no primeiro reator, confirmando que, quando ocorre aumento da carga orgânica no sistema a eficiência da degradação da matéria orgânica diminui.

A DQO devido à fração de sólidos suspensos (SS) no efluente do primeiro reator correspondeu em média $62 \%, 66 \%$ e $75 \%$ e no efluente do segundo reator a $30 \%, 49 \%$ e $71 \%$ da $\mathrm{DQO}_{\text {total }}$, respectivamente, para os ensaios 1, 2 e 3. As eficiências de remoção de DQO $\mathrm{O}_{\text {total}}$, dissolvida e devido à fração de sólidos suspensos obtidos nos ensaios do experimento, estão apresentados nas Figuras 4.10, 4.11 e 4.12, respectivamente. 


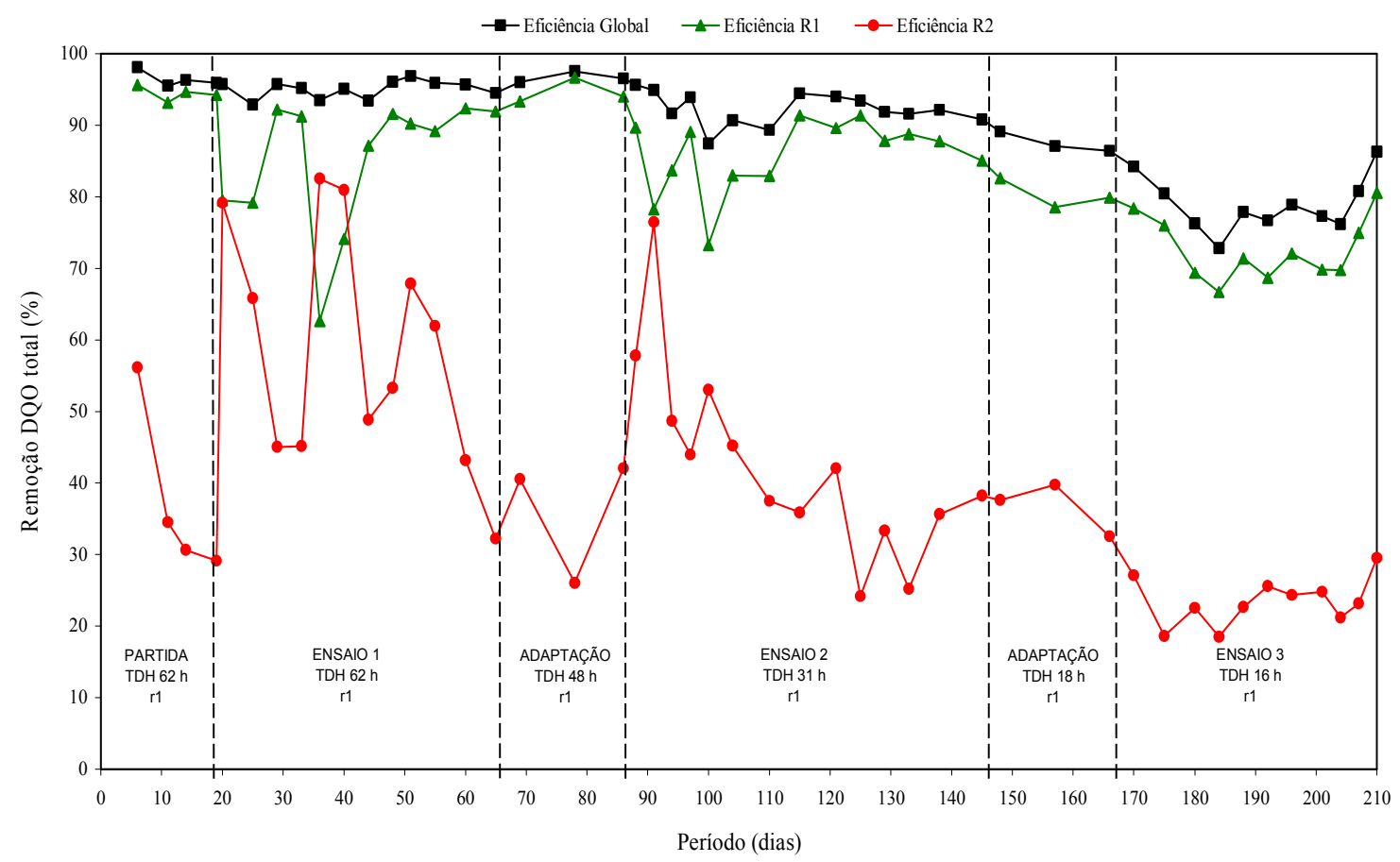

Figura 4.10. Eficiências de remoção de $\mathrm{DQO}_{\text {total }}$ obtidas no primeiro e segundo reatores nos ensaios 1, 2 e 3.

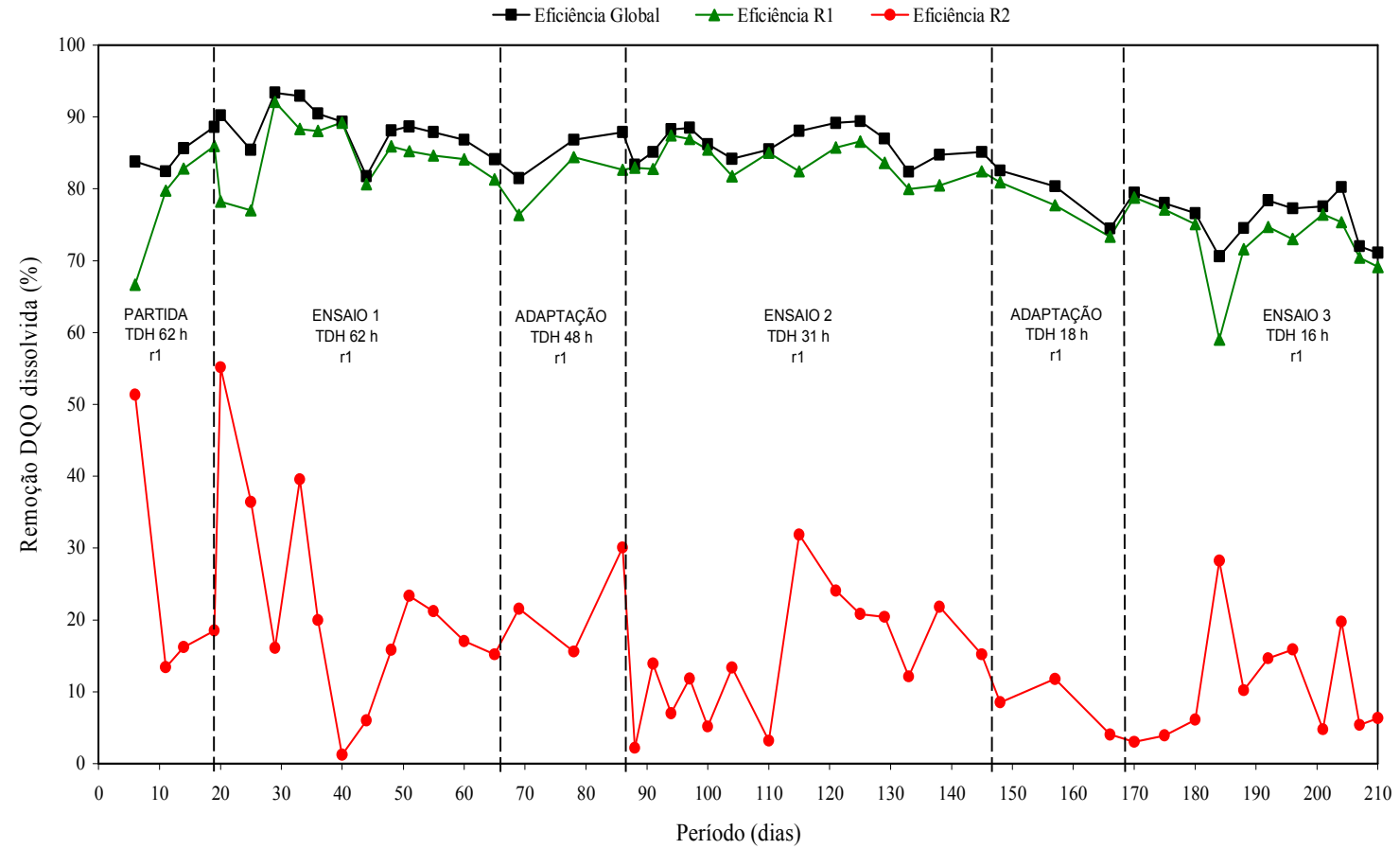

Figura 4.11. Eficiências de remoção de $\mathrm{DQO}_{\text {dissolvida }}$ obtidas no primeiro e segundo reatores nos ensaios 1,2 e 3 . 


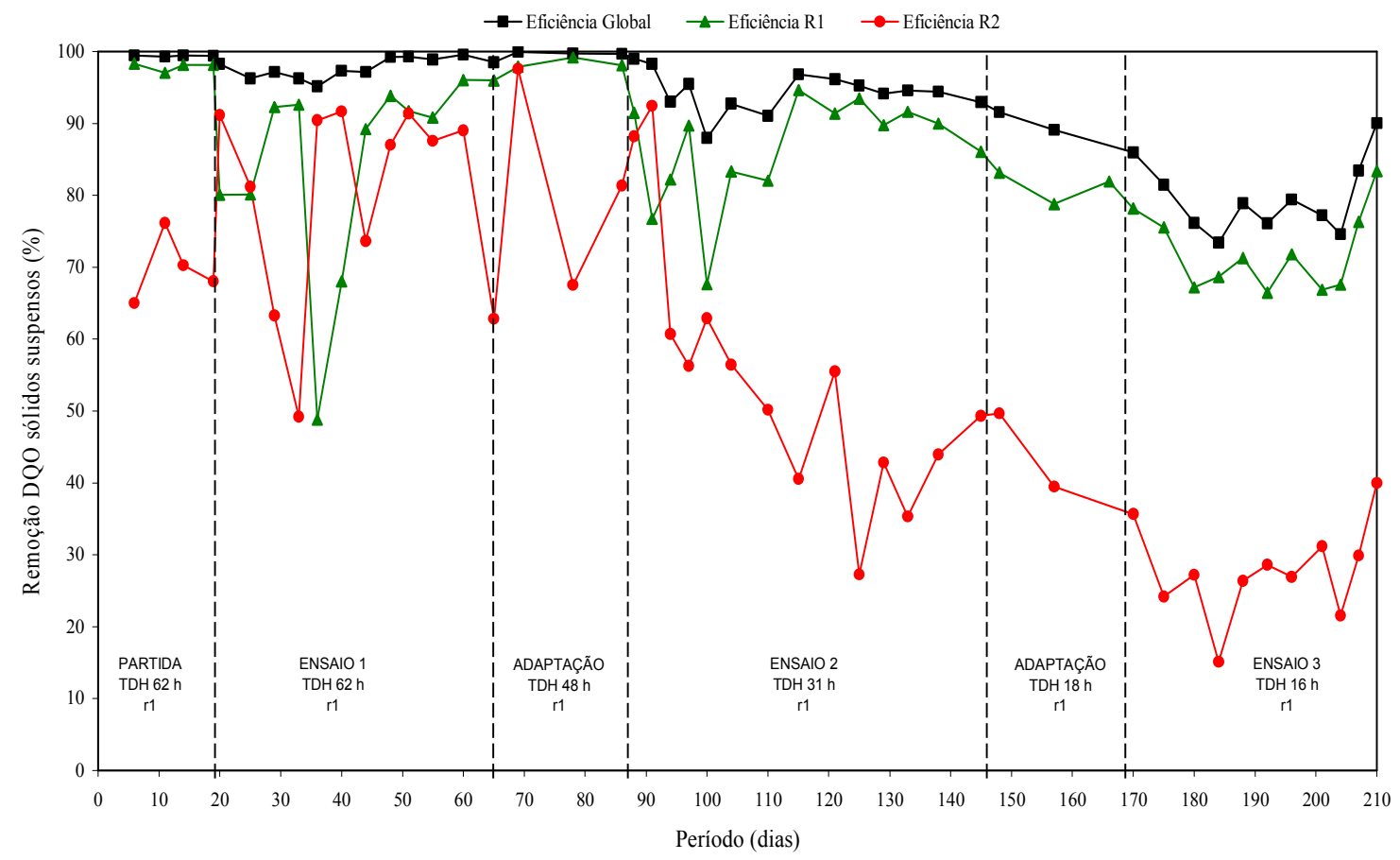

Figura 4.12. Eficiências de remoção de DQO devido à fração de sólidos suspensos obtidas no primeiro e segundo reatores nos ensaios 1,2 e 3 .

Os valores numéricos obtidos no primeiro reator situaram-se próximos aos obtidos por Oliveira (1997) em termos percentuais de DQO formada por fração sólida em suspensão. Por outro lado, no segundo reator, ocorreu elevação da DQO formada por fração sólida em suspensão em 41\%, do ensaio 1 para o ensaio 3, devido, provavelmente, ao arraste de sólidos no sistema proporcionado pelo aumento da taxa de carregamento orgânico e da produção de biogás.

A variação da taxa de carregamento orgânico volumétrico (TCOV), no primeiro reator, de 4,55 a 18,65 kg DQO total $_{1} \cdot \mathrm{m}^{-3} \cdot \operatorname{dia}^{-1}$ e de 2,55 a 21,03 $\mathrm{kg} \mathrm{DQO}_{\text {total }} \cdot \mathrm{m}^{-3} \cdot \operatorname{dia}^{-1}$, no segundo reator, não foram limitantes para obtenção de altas eficiências de remoção de $\mathrm{DQO}_{\text {total }}$ no sistema (superiores a $79 \%$ ).

No processo anaeróbio, valores superiores a $65 \%$ na remoção de matéria orgânica são considerados como satisfatórios para o tratamento de águas residuárias (CHERNICHARO, 1997). 
Através das Figuras 4.10, 4.11 e 4.12, observa-se que a eficiência de remoção global do sistema manteve-se praticamente constante ao longo do experimento apresentando CV baixos de 2,3 a 3,9 \%. Nota-se que quando ocorria queda de eficiência do primeiro reator, em

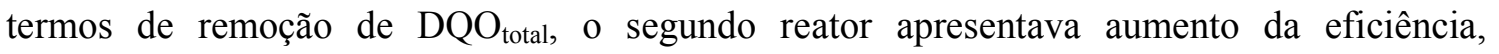
absorvendo as variações de cargas impostas na saída do primeiro reator. Os valores de CV médios de 13,0 a 32,6\%, observados no segundo reator, foram maiores que os valores médios obtidos no primeiro reator, de 5,5 a 11,6\%, devido, provavelmente, as maiores instabilidades operacionais como: entupimentos, sobrecargas hidráulicas e maior arraste de sólidos, verificadas no segundo reator, o que não afetou a obtenção de altas eficiências de remoção de $\mathrm{DQO}_{\text {total }}$ no sistema (acima de $79 \%$ ) e valores de CV no sistema baixos, de 1,1 a 5,1. As frações de $\mathrm{DQO}_{\text {dissolvida }} \mathrm{e}$ devida a sólidos suspensos apresentaram tendência similar à apresentada pela $\mathrm{DQO}_{\text {total. }}$

Observa-se então, nos resultados obtidos, a vantagem de se usar sistemas de tratamento em dois estágios em relação aos sistemas de único estágio, onde o segundo reator trabalharia absorvendo as variações de eficiência do primeiro reator, melhorando a qualidade do efluente final e proporcionando maior eficiência e melhor estabilização da matéria orgânica.

Sayed e Fergala (1995), utilizando reatores UASB em série, verificaram considerável aumento da eficiência de remoção de DQO com a diminuição do TDH, com eficiência de tratamento do sistema de $75 \%$ para TDH de 10 h e $84 \%$ para TDH de 6 h. Kalyuzhnyi et al. (1998) utilizaram reatores UASB no tratamento de resíduos de aves, com TCOV de 11 a 12 $\mathrm{kg}$ DQO $_{\text {total }} \cdot \mathrm{m}^{-3} \cdot \mathrm{d}^{-1}$, TDH de 24 a $48 \mathrm{~h}$, e obtiveram eficiências de remoção de DQO total $_{\text {de }} 70 \mathrm{a}$ $75 \%$.

Oliveira (2000) utilizando dois reatores UASB em série com TDH de 14,7 h em cada reator, TCOV de 5 a $8 \mathrm{~kg} \mathrm{DQO} \mathrm{Dtotal}_{\mathrm{m}} \mathrm{m}^{-3} \cdot \mathrm{d}^{-1}$, no primeiro reator, e concentração de $\mathrm{SST}$ do afluente de 750 a 2300 mg.L $\mathrm{L}^{-1}$ obteve eficiências de remoção de DQO e SST no sistema de 80 a $64 \%$ e 79 a $65 \%$, respectivamente. Dando seqüência ao trabalho, Oliveira (2001) operou o mesmo sistema com TDH de 7,3 h em cada reator, TCOV de 11 a $14 \mathrm{~kg}$ DQO $_{\text {total }} \cdot \mathrm{m}^{-3} \cdot \mathrm{d}^{-1}$ no primeiro reator, com o afluente com valores médios de SST de 1338 a 2197 mg.L $\mathrm{L}^{-1}$ e adotou a prática do descarte periódico do excesso de lodo. Obteve eficiência de remoção de $\mathrm{DQO}_{\text {total }}$ de 71 e $81 \%$ e SST de 69 e $85 \%$. O segundo reator sempre apresentou menor eficiência que o primeiro reator na remoção de DQO e SST nas condições estudadas pelo autor.

Os resultados obtidos por Oliveira $(2000,2001)$ são semelhantes aos obtidos neste estudo, com eficiências de remoção de DQO e SST no sistema acima de 79 e 73\%, respectivamente. Embora o segundo reator tenha apresentado menor eficiência na remoção da 
matéria orgânica, contribuiu para a manutenção da eficiência de remoção do sistema estudado. A contribuição do segundo reator deveu-se, principalmente, a acomodação de sobrecargas e atenuação dos arrastes de lodo da manta do primeiro reator (OLIVEIRA, 2001).

Comparativamente aos resultados obtidos neste estudo, observa-se o contrário daqueles obtidos por Sayed e Fergala (1995), com queda da eficiência de tratamento pelo sistema quando da diminuição do TDH. A queda da eficiência de tratamento foi mais acentuada no segundo reator com a diminuição do TDH e conseqüente aumento da TCOV, indicando tendências de redução de eficiência quando aumentada a carga orgânica.

Sayed et al. (1993) obtiveram remoção de $\mathrm{DQO}_{\text {total }}$ no sistema superiores a 90\%, com TCOV até $15 \mathrm{~kg} \mathrm{DQO}$ total. $\mathrm{m}^{-3} \cdot \mathrm{d}^{-1}$, semelhantes aos resultados obtidos neste estudo nos ensaios 1 e 2. Entretanto, diferentemente dos resultados apresentados por Sayed et al. (1993), o segundo reator apresentou baixas remoções das frações de $\mathrm{DQO}_{\text {total }} \mathrm{e}_{\text {dissolvida, }}$ sendo de $23 \% \mathrm{a}$ $59 \%$ e $11 \%$ a $22 \%$. Em relação à remoção de DQO devido à fração de sólidos suspensos, o resultado obtido foi igual ao observado pelos autores, para o ensaio 1 deste experimento. Com a diminuição do TDH e o aumento da taxa de carregamento orgânico para $21,03 \mathrm{~kg}$ $\mathrm{DQO}_{\text {total }} \cdot \mathrm{m}^{-3} \cdot \mathrm{d}^{-1}$, no ensaio 3 , houve queda acentuada da eficiência de remoção no segundo reator, para $28 \%$, devido, provavelmente, ao arraste de sólidos.

\subsubsection{Sólidos suspensos}

Na Tabela 4.2 estão apresentados os resultados médios, as eficiências de remoção (E) e os coeficientes de variação (CV) das concentrações de SST e SSV, obtidos durante a operação do sistema em dois estágios nos ensaios 1, 2 e 3 do experimento. Os resultados utilizados para o cálculo dos valores médios de SST, SSV e SSF, obtidos durante os ensaios, estão apresentados nas Figuras 4.13, 4.14 e 4.15. 
Tabela 4.2. Valores médios e coeficiente de variação (CV) das concentrações de SST e SSV no afluente e efluente e eficiência de remoção (E), obtidos durante a operação do sistema em dois estágios, primeiro (r1) e segundo (r2) reatores, nos ensaios 1,2 e 3.

\begin{tabular}{|c|c|c|c|c|c|c|c|c|c|c|c|c|c|c|}
\hline \multirow[t]{3}{*}{ Ensaio } & \multirow{2}{*}{\multicolumn{2}{|c|}{$\begin{array}{r}\text { TDH } \\
\text { (h) }\end{array}$}} & \multicolumn{7}{|c|}{$\begin{array}{c}\text { SST } \\
\left(\mathrm{mg}^{\left.-L^{-1}\right)}\right.\end{array}$} & \multirow{2}{*}{\multicolumn{2}{|c|}{$\begin{array}{c}\text { SSV } \\
\left(\mathbf{m g . L ^ { - 1 } )}\right. \\
\text { efluente }\end{array}$}} & \multirow{2}{*}{\multicolumn{3}{|c|}{ E $(\%)$}} \\
\hline & & & \multirow[t]{2}{*}{ afl. } & \multicolumn{2}{|c|}{ efluente } & \multicolumn{3}{|c|}{ E (\%) } & \multirow[t]{2}{*}{ afl. } & & & & & \\
\hline & $\mathrm{r} 1$ & r2 & & $\mathrm{r} 1$ & $\mathrm{r} 2$ & $\mathrm{r} 1$ & $\mathrm{r} 2$ & global & & $\mathrm{r} 1$ & $\mathrm{r} 2$ & $\mathrm{r} 1$ & $\mathrm{r} 2$ & globa \\
\hline 1 & 62 & 16 & 5240 & 960 & 300 & 82 & 57 & 94 & 4740 & 830 & 260 & 83 & 58 & 95 \\
\hline 2 & 31 & 8 & 5000 & 820 & 590 & 85 & 58 & 94 & 4600 & 730 & 510 & 85 & 59 & 95 \\
\hline 3 & 16 & 4 & 5490 & 1880 & 1490 & 65 & 20 & 73 & 5000 & 1700 & 1320 & 65 & 21 & 73 \\
\hline $\mathrm{C}$ & 62 & 16 & 13,0 & 75,0 & 30,0 & 15,7 & 38,1 & 2,1 & 13,7 & 78,3 & 30,8 & 15,1 & 34,4 & 2,0 \\
\hline $\mathrm{V}$ & 31 & 8 & 15,6 & 43,9 & 137,3 & 8,4 & 25,4 & 1,4 & 13,7 & 45,2 & 147,1 & 8,1 & 25,6 & 1,2 \\
\hline$(\%)$ & 16 & 4 & 10,9 & 20,7 & 14,8 & 17,5 & 55,8 & 6,8 & 14,4 & 20,0 & 15,9 & 19,4 & 50,4 & 7,2 \\
\hline
\end{tabular}

De acordo com os resultados pode-se observar que as concentrações de SST no afluente apresentaram valores, em média, sempre próximos ao esperado de $5000 \mathrm{mg} . \mathrm{L}^{-1} \mathrm{e}$ coeficiente de variação (CV) de 10,9\% a 15,6\%. A concentração de SSV representou, em média, 91 a $92 \%$ da concentração de SST do afluente.

O coeficiente de variação $(\mathrm{CV})$ da concentração de SST no efluente do primeiro reator, nos ensaios do experimento, variou de 20,7\% a 75,0\% e no efluente do segundo reator de $14,8 \%$ a $137,3 \%$. Para SSV a variação foi de $20,0 \%$ a $78,3 \%$, no efluente do primeiro reator, e de $15,9 \%$ a $147,1 \%$, no efluente do segundo reator. De acordo com Oliveira (1997) estes valores altos podem ser atribuídos à imprecisão da metodologia de análise utilizada para a faixa de SS encontrada e também às variações intrínsecas do parâmetro no processo. $\mathrm{O}$ arraste de sólidos do reator, nos dias finais de cada ensaio, contribuiu para aumento significativo da concentração de sólidos no efluente, ocasionando altos valores de CV.

A eficiência de remoção de SST nos ensaios 1, 2 e 3 do experimento, no primeiro reator foi, respectivamente, de $82 \%, 85 \%$ e $65 \%$; e no segundo reator de $57 \%$, $58 \%$ e $20 \%$. Para SSV a eficiência de remoção nos ensaios 1 e 2 foi semelhante à remoção de SST, sendo, respectivamente, de $83 \%$ a $85 \%$ para o primeiro reator e $58 \%$ a $59 \%$ para o segundo reator. Com a diminuição do TDH, no ensaio 3, observou-se queda da eficiência de remoção de SSV, no primeiro e segundo reatores, para $65 \%$ e $21 \%$, respectivamente. Isso deve-se, 
provavelmente, ao aumento do arraste de sólidos do sistema provocado pela diminuição do TDH e aumento da produção de biogás.

A eficiência de remoção média de SST e SSV do sistema foi, respectivamente, de 94\% e 95\% para os ensaios 1 e 2, apresentando queda para 73\% no ensaio 3. As eficiências de remoção de SST e SSV estão apresentadas na Figuras 4.16 e 4.17.

A relação de SSV/SST no efluente variou, nos ensaios do experimento, de 0,84 a 0,89 no primeiro reator e de 0,85 a 0,90 no segundo reator.

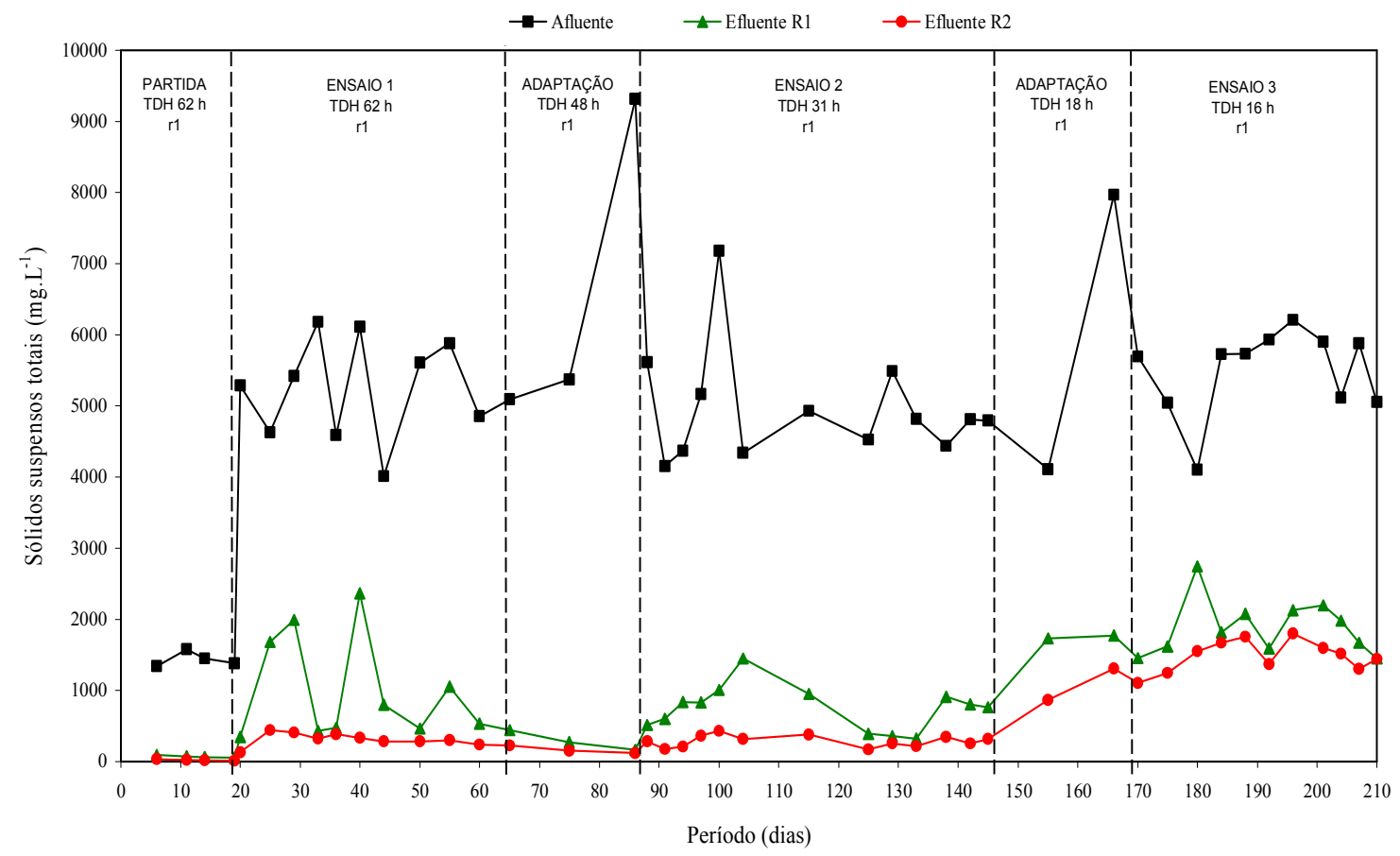

Figura 4.13. Concentrações de sólidos suspensos totais (SST) obtidas no afluente e efluentes do primeiro e segundo reatores nos ensaios 1,2 e 3. 


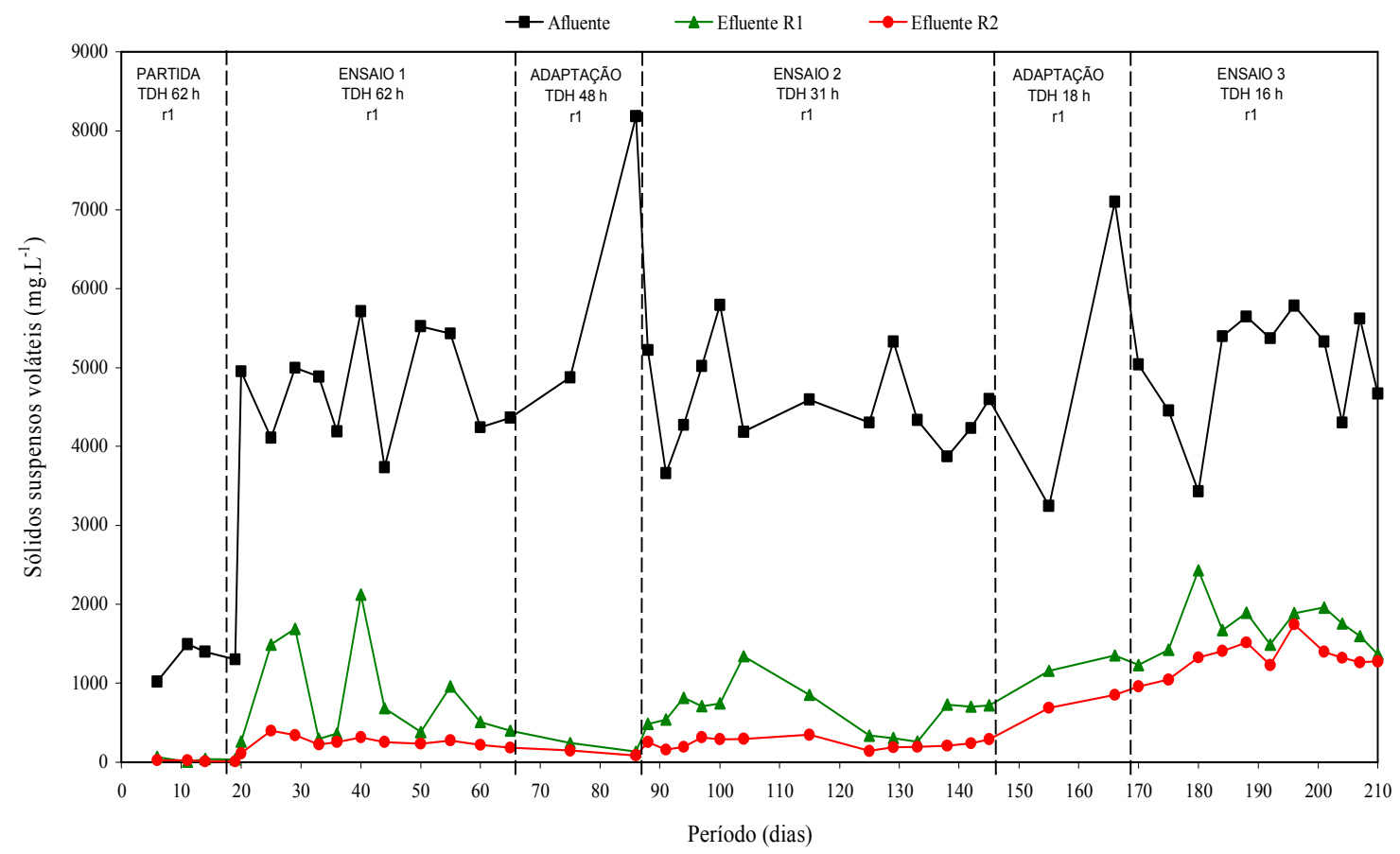

Figura 4.14. Concentrações de sólidos suspensos voláteis (SSV) obtidas no afluente e efluentes do primeiro e segundo reatores nos ensaios 1,2 e 3.

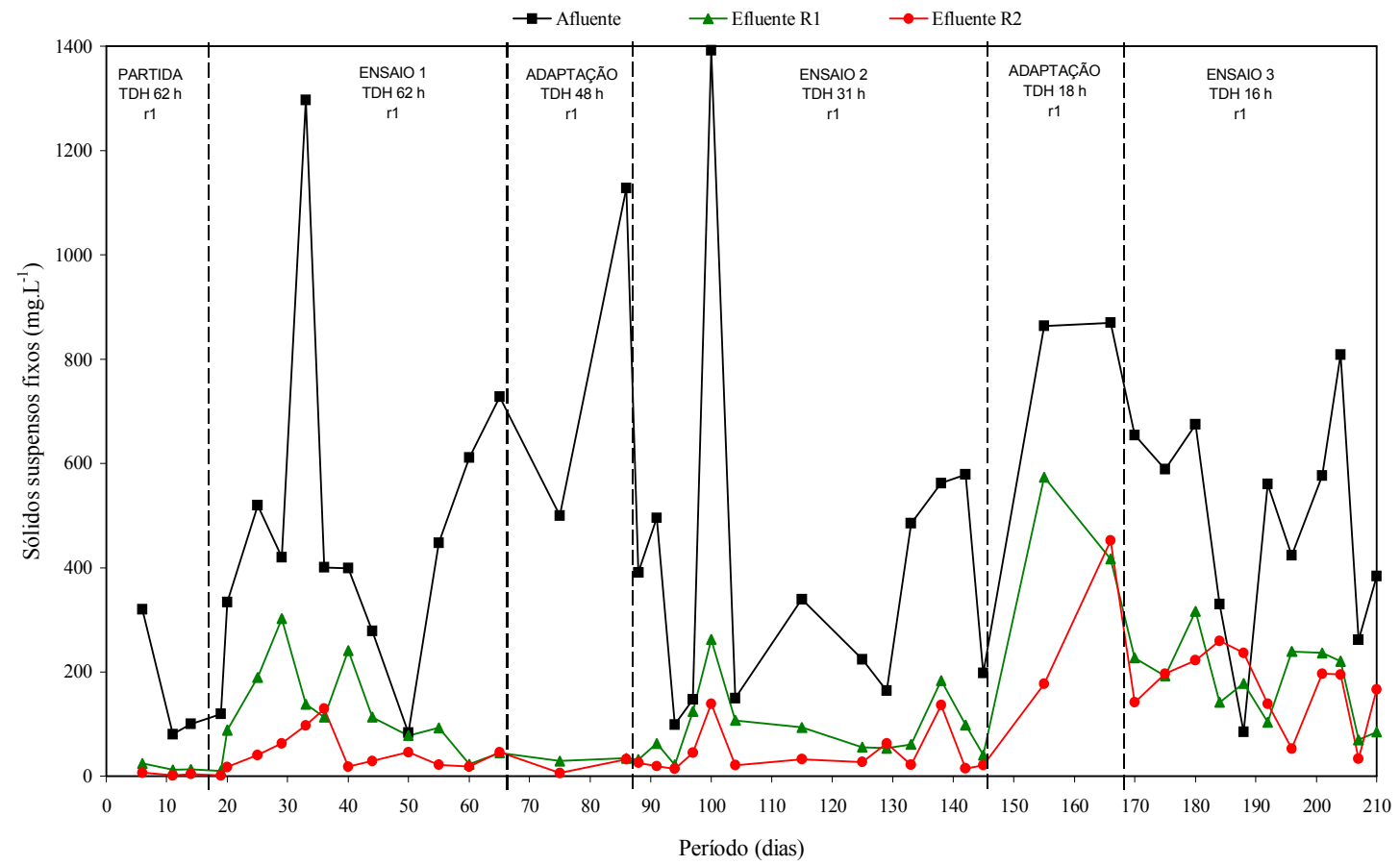

Figura 4.15. Concentrações de sólidos suspensos fixos (SSF) obtidas no afluente e efluentes do primeiro e segundo reatores nos ensaios 1,2 e 3 . 


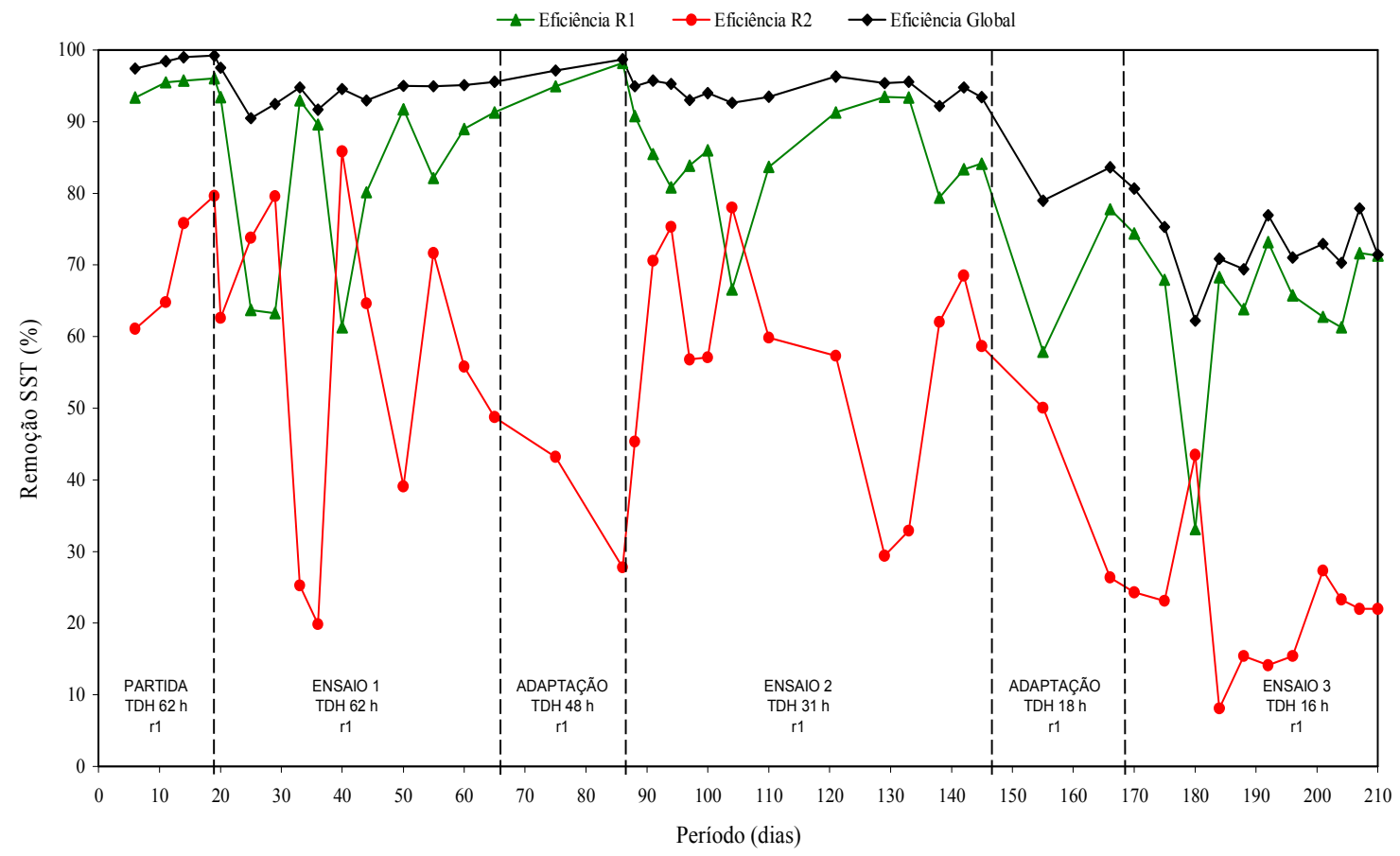

Figura 4.16. Eficiências de remoção de SST obtidas no primeiro e segundo reatores nos ensaios 1, 2 e 3.

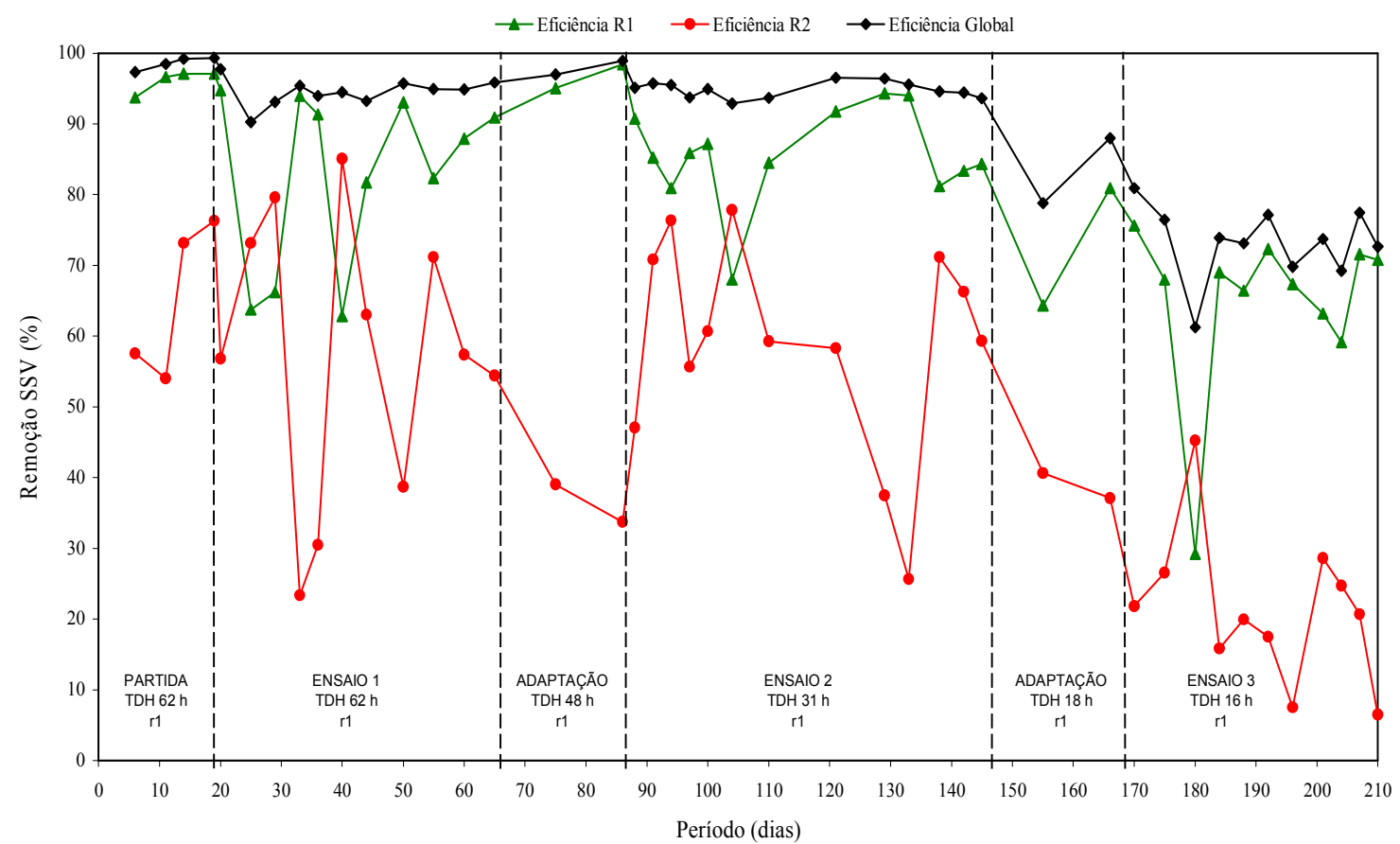

Figura 4.17. Eficiências de remoção de SSV obtidas no primeiro e segundo reatores nos ensaios 1, 2 e 3. 
Nas Figuras 4.16 e 4.17, observa-se que a eficiência de remoção global de sólidos do sistema manteve-se praticamente constante durante os ensaios 1 e 2 com TCOV de 4,55 a $8,75 \mathrm{~kg} \mathrm{DQO}$ total $\cdot \mathrm{m}^{-3} \cdot \mathrm{d}^{-1}$, apresentando redução de eficiência no ensaio $3 \mathrm{com}$ o aumento da TCOV para $18,65 \mathrm{~kg} \mathrm{DQO}_{\text {total }} \cdot \mathrm{m}^{-3} \cdot \mathrm{d}^{-1}$. Pôde-se observar que quando ocorreu redução de eficiência no primeiro reator, na remoção de sólidos suspensos, o segundo reator apresentou aumento da eficiência, absorvendo as variações de cargas impostas na saída do primeiro reator, como também observado para remoção de DQO. Os valores de CV médios de SST e SSV de 25,4 a $55,8 \%$ e 25,6 a 50,4, respectivamente, observados no segundo reator, foram maiores que os valores médios obtidos no primeiro reator, de 8,4 a 15,7 \% e 8,1 a 19,4, respectivamente, devido, provavelmente, as maiores instabilidades operacionais como: entupimentos, sobrecargas hidráulicas e maior arraste de sólidos, verificadas no segundo reator, o que não afetou a obtenção de altas eficiências de remoção de sólidos suspensos no sistema (acima de 73 \%) e valores de CV no sistema baixos, de 1,2 a 7,2 \%.

\subsubsection{Manta de lodo: sólidos totais e voláteis}

Nas Tabelas 4.3 e 4.4 estão apresentados os valores médios da concentração de sólidos totais (ST) e voláteis (SV) ao longo da manta de lodo, obtidos das amostras retiradas nos pontos de coleta, indicados na Figura 3.2, para o primeiro reator, e na Figura 3.4, para o segundo reator. A taxa de carregamento no lodo (TCL) foi obtida utilizando-se os valores médios de SV do lodo e da DQO afluente do primeiro e segundo reatores. Os resultados utilizados para o cálculo dos valores médios de ST e SV, para o primeiro e segundo reatores, obtidos durante os ensaios, estão apresentados nas Figuras 4.18 e 4.19; 4.20 e 4.21, respectivamente.

No primeiro reator observou-se, nos ensaios 1 e 2, que os valores de ST do lodo nos pontos 1, 3 e 5 decresceram na média com a diminuição do TDH e aumento da TCOV sendo, respectivamente, de 48000 a $43000 \mathrm{mg} . \mathrm{L}^{-1}, 47000$ a $41000 \mathrm{mg} . \mathrm{L}^{-1}$ e 46000 a $43000 \mathrm{mg} . \mathrm{L}^{-1}$. Os valores de SV apresentaram o mesmo comportamento com queda de 38000 para 34000 mg. $\mathrm{L}^{-1}$, 38000 para $33000 \mathrm{mg} . \mathrm{L}^{-1}$ e 37000 para $35000 \mathrm{mg} . \mathrm{L}^{-1}$. No ensaio 3 observou-se aumento dos valores de ST e SV, nos pontos 1 e 3, atingindo 66000 e 47000 mg.L - $^{-1} 63000$ e $45000 \mathrm{mg} . \mathrm{L}^{-1}$, respectivamente.

Nos pontos 7 e 8 os valores de ST e SV aumentaram com a diminuição do TDH e aumento da TCOV, nos ensaios 1 e 2, apresentando valores médios de 22000 a 34000 mg.L $\mathrm{L}^{-1}$ 
e 17000 a $27000 \mathrm{mg} . \mathrm{L}^{-1}$; 9000 a $28000 \mathrm{mg} \cdot \mathrm{L}^{-1}$ e 6000 a $23000 \mathrm{mg} \cdot \mathrm{L}^{-1}$, respectivamente, e decresceram novamente no ensaio 3 .

No segundo reator, nos ensaios 1 e 2, os valores médios de ST nos pontos 2, 3 e 4 apresentaram decréscimo de 49000 a 36000 mg. $\mathrm{L}^{-1}, 40000$ a $31000 \mathrm{mg} . \mathrm{L}^{-1}$ e 32000 a 25000 mg. $\mathrm{L}^{-1}$; os SV tiveram a mesma tendência de queda apresentando valores de 38000 a 28000 mg. $\mathrm{L}^{-1}, 32000$ a $24000 \mathrm{~m}$ g. $\mathrm{L}^{-1}$ e 25000 a 19000 mg.L $\mathrm{L}^{-1}$, respectivamente. No ponto 1 os valores de ST e SV não sofreram alterações com a diminuição do TDH e aumento da TCOV, sendo de 55000 e $40000 \mathrm{mg} . \mathrm{L}^{-1}$, respectivamente, e no ponto 5 houve acréscimo de 22000 para $26000 \mathrm{mg} . \mathrm{L}^{-1}$ e 17000 para $20000 \mathrm{mg} . \mathrm{L}^{-1}$.

No ensaio 3 observou-se aumento dos valores de ST e SV nos pontos 1 e 2, sendo de 74000 e 48000 mg.L $L^{-1} ; 42000$ e 34000 mg.L $L^{-1}$, respectivamente, e diminuição dos valores nos pontos 3, 4 e 5 para 25000 e 21000 mg.L $\mathrm{L}^{-1} ; 18000$ e $14000 \mathrm{mg} . \mathrm{L}^{-1} ; 19000$ e $15000 \mathrm{mg} . \mathrm{L}^{-1}$.

Tabela 4.3. Valores médios de sólidos totais (ST) e voláteis (SV), coeficiente de variação (CV) e taxa de carregamento no lodo (TCL), obtidos através de perfis da manta do primeiro reator durante a operação do sistema em dois estágios nos ensaios 1, 2 e 3 do experimento.

\begin{tabular}{|c|c|c|c|c|c|c|c|c|c|c|c|c|c|}
\hline \multirow[t]{3}{*}{ Ensaio } & \multirow{2}{*}{\multicolumn{2}{|c|}{$\begin{array}{l}\text { TDH } \\
\text { (h) }\end{array}$}} & \multicolumn{2}{|c|}{ Ponto1 } & \multicolumn{2}{|c|}{ Ponto 3} & \multicolumn{2}{|c|}{ Ponto 5} & \multicolumn{2}{|c|}{ Ponto 7} & \multicolumn{2}{|c|}{ Ponto 8} & \multirow[t]{3}{*}{ TCL } \\
\hline & & & ST & SV & ST & SV & ST & SV & ST & SV & ST & SV & \\
\hline & $\mathrm{r} 1$ & $\mathrm{r} 2$ & \multicolumn{10}{|c|}{$\left(\mathrm{mg} \mathrm{L}^{-1}\right)$} & \\
\hline 1 & 62 & 16 & 48000 & 38000 & 47000 & 38000 & 46000 & 37000 & 22000 & 17000 & 9000 & 6000 & 0,26 \\
\hline 2 & 31 & 8 & 43000 & 34000 & 41000 & 33000 & 43000 & 35000 & 34000 & 27000 & 28000 & 23000 & 0,80 \\
\hline 3 & 16 & 4 & 65600 & 47060 & 63210 & 45060 & 36070 & 29010 & 15500 & 13110 & 14960 & 12360 & 3,83 \\
\hline $\mathrm{C}$ & 62 & 16 & 3,1 & 3,5 & 6,4 & 6,9 & 9,7 & 9,8 & 93,8 & 98,6 & 87,6 & 100,7 & 7,7 \\
\hline V & 31 & 8 & 11,3 & 9,1 & 3,1 & 3,2 & 2,1 & 1,9 & 38,3 & 39,3 & 39,0 & 40,3 & 12,5 \\
\hline (\%) & 16 & 4 & 12,8 & 7,0 & 22,8 & 8,9 & 18,1 & 16,1 & 8,8 & 4,8 & 7,3 & 3,9 & 8,6 \\
\hline
\end{tabular}


Tabela 4.4. Valores médios de sólidos totais (ST) e voláteis (SV), coeficiente de variação (CV) e taxa de carregamento no lodo (TCL), obtidos através de perfis da manta do segundo reator durante a operação do sistema em dois estágios nos ensaios 1,2 e 3.

\begin{tabular}{|c|c|c|c|c|c|c|c|c|c|c|c|c|c|}
\hline \multirow[t]{3}{*}{ Ensaio } & \multirow{2}{*}{\multicolumn{2}{|c|}{$\begin{array}{c}\text { TDH } \\
\text { (h) }\end{array}$}} & \multicolumn{2}{|c|}{ Ponto1 } & \multicolumn{2}{|c|}{ Ponto 2} & \multicolumn{2}{|c|}{ Ponto 3} & \multicolumn{2}{|c|}{ Ponto 4} & \multicolumn{2}{|c|}{ Ponto 5} & \multirow[t]{3}{*}{ TCL } \\
\hline & & & ST & SV & ST & SV & ST & SV & ST & SV & ST & SV & \\
\hline & $\mathrm{r} 1$ & $\mathrm{r} 2$ & \multicolumn{10}{|c|}{$\left(\mathrm{mg} \mathrm{L}^{-1}\right)$} & \\
\hline 1 & 62 & 16 & 55000 & 40000 & 49000 & 38000 & 40000 & 32000 & 32000 & 25000 & 22000 & 17000 & 0,06 \\
\hline 2 & 31 & 8 & 55000 & 39000 & 36000 & 28000 & 31000 & 24000 & 25000 & 19000 & 26000 & 20000 & 0,09 \\
\hline 3 & 16 & 4 & 74050 & 47630 & 41870 & 34180 & 24630 & 20500 & 17590 & 14130 & 18690 & 14810 & 2,23 \\
\hline $\mathrm{C}$ & 62 & 16 & 6,1 & 3,3 & 6,3 & 5,3 & 25,4 & 23,7 & 63,5 & 65,4 & 71,1 & 74,1 & 66,7 \\
\hline $\mathrm{V}$ & 31 & 8 & 5,9 & 3,1 & 3,2 & 2,7 & 1,3 & 0,5 & 14,0 & 14,6 & 19,0 & 18,8 & 44,4 \\
\hline$(\%)$ & 16 & 4 & 34,6 & 8,4 & 18,6 & 24,4 & 21,4 & 28,8 & 25,7 & 31,2 & 8,1 & 10,0 & 14,8 \\
\hline
\end{tabular}

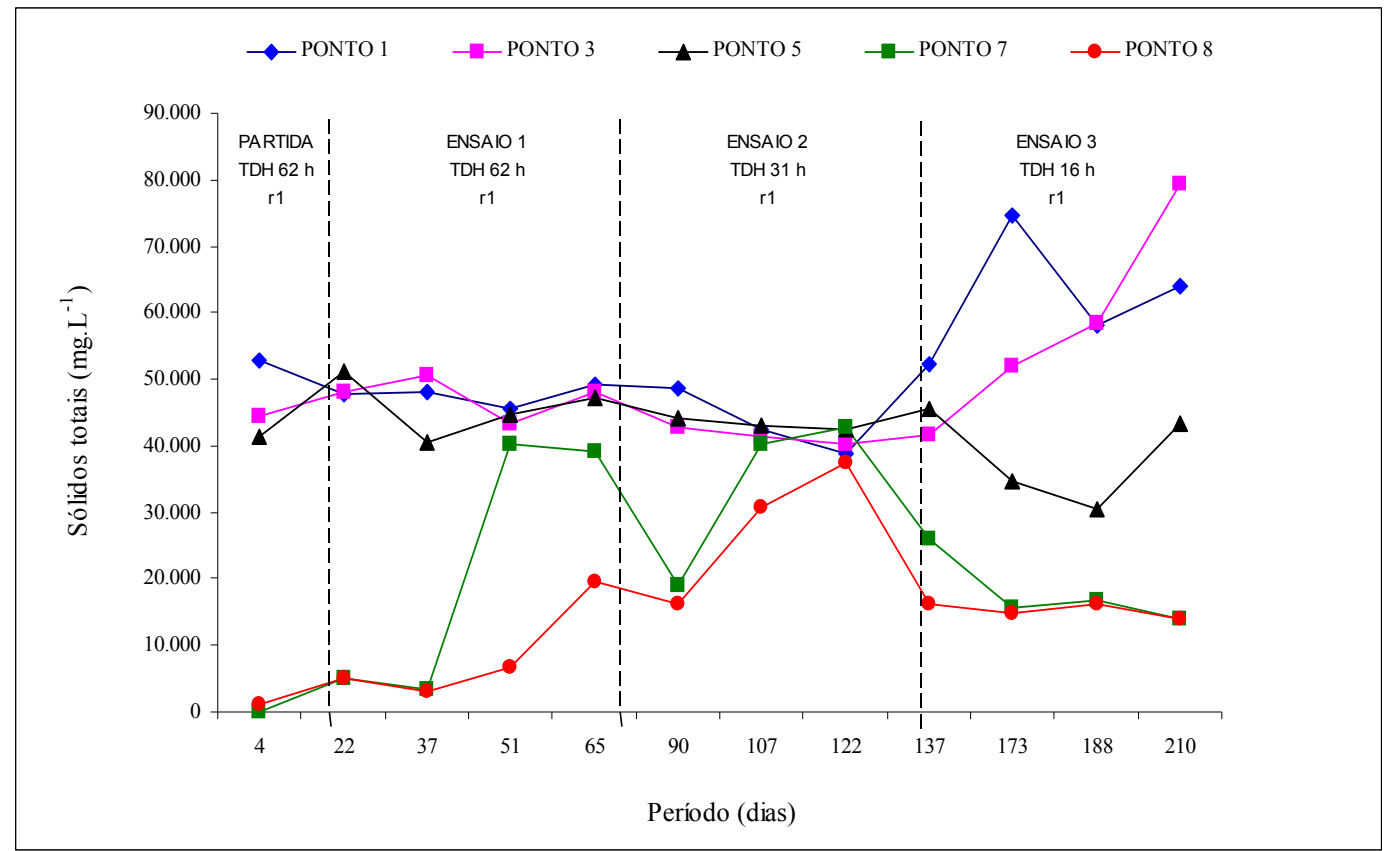

Figura 4.18. Concentrações de sólidos totais (ST) obtidos através de perfis da manta do primeiro reator durante a operação do sistema em dois estágios nos ensaios 1,2 e 3 . 


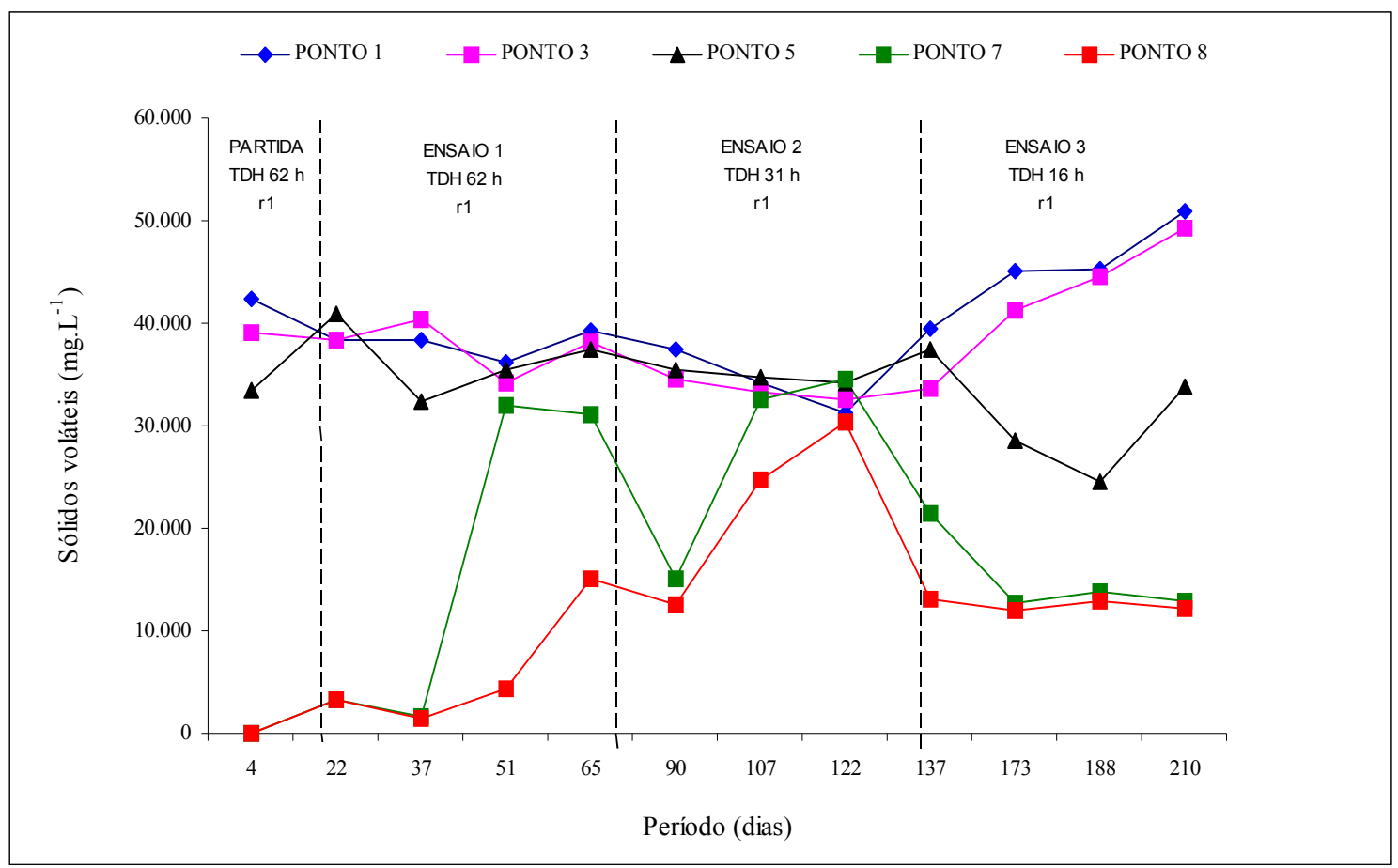

Figura 4.19. Concentrações de sólidos voláteis (SV) obtidos através de perfis da manta do primeiro reator durante a operação do sistema em dois estágios nos ensaios 1,2 e 3.

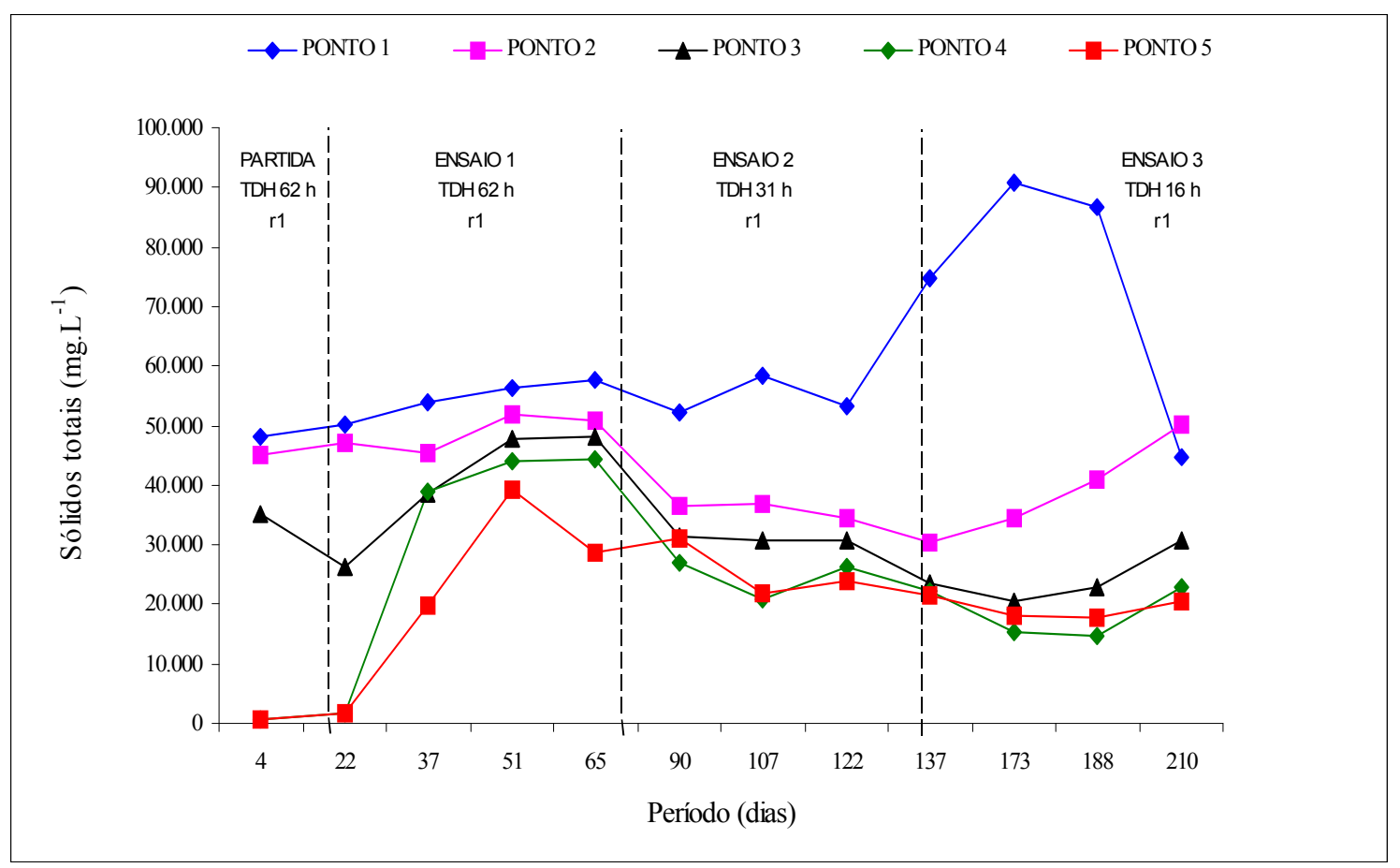

Figura 4.20. Concentrações de sólidos totais (ST) obtidos através de perfis da manta do segundo reator durante a operação do sistema em dois estágios nos ensaios 1,2 e 3. 


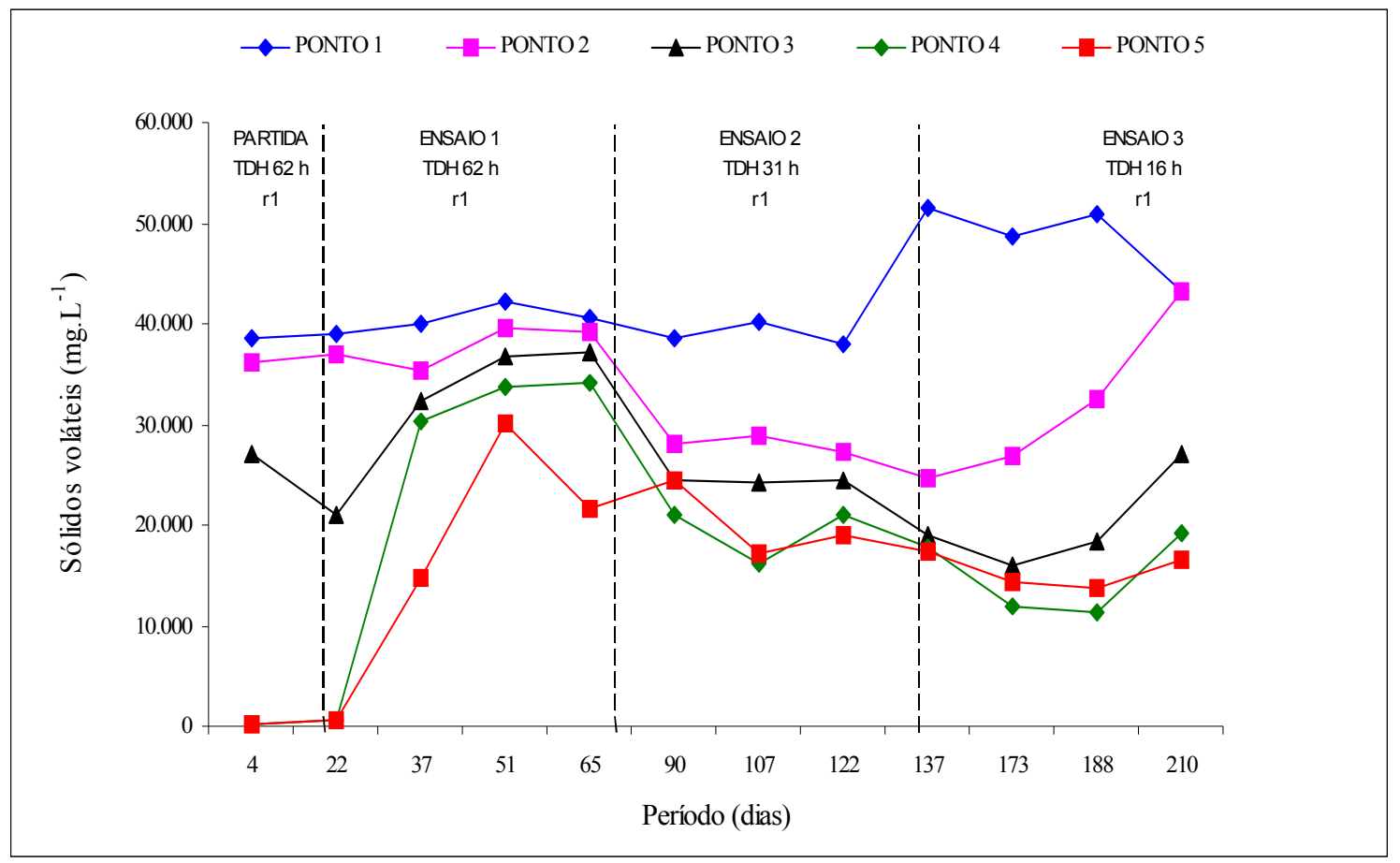

Figura 4.21. Concentrações de sólidos voláteis (SV) obtidos através de perfis da manta do segundo reator durante a operação do sistema em dois estágios nos ensaios 1, 2 e 3.

Observa-se que as variações nas concentrações de ST e SV na manta de lodo dos reatores, provavelmente, ocorreram devido a dois fatores. O primeiro fator foi a retenção de sólidos no sistema e o crescimento celular observado através do aumento da manta de lodo. $\mathrm{O}$ segundo fator foi o revolvimento da manta de lodo, principalmente no segundo reator, provocado por entupimentos da mangueira que ligava os dois reatores. Quando da limpeza da mangueira ocorria uma sobrecarga hidráulica com o efluente do primeiro passando para o segundo reator ocasionando a mistura da manta de lodo no segundo reator. Outro fator que pode ter contribuído para o revolvimento da manta de lodo foram as altas produções de gás observadas no sistema, que ocorriam na forma de pulsos.

Oliveira (1997) observou maiores concentrações de SSV na parte intermediária e inferior da manta de lodo de reatores UASB tratando águas residuárias de suinocultura e associou à presença de lodo granulado mais denso, de maior diâmetro e em maior quantidade, refletindo-se, geralmente, na maior taxa de remoção bioquímica nestas regiões. As observações do autor também foram evidenciadas neste estudo e os valores de SV obtidos estão de acordo com as constatações de Stronach $^{2}$ et al. (1986 apud OLIVEIRA, 1997), onde

\footnotetext{
${ }^{2}$ STRONACH, S.M., RUDD, T., LESTER, J.N. (1986). Anaerobic digestion process in industrial wastewater treatment. Berlin Heidelberg, Germany. Springer-Verlag.
} 
a concentração de SV do lodo normalmente encontrada varia de 10000 a 30000 mg.L $\mathrm{L}^{-1}$ na parte superior da manta e de 40000 a $70000 \mathrm{mg} . \mathrm{L}^{-1}$ na parte inferior do leito.

\subsubsection{Produção de metano}

Na Tabela 4.5 estão apresentados os resultados médios e os coeficientes de variação (CV) da porcentagem de metano $\left(\mathrm{CH}_{4}\right)$ no biogás e das produções diária, volumétrica e específica de $\mathrm{CH}_{4}$ obtidos durante a operação do sistema em dois estágios nos ensaios 1,2 e 3 do experimento.

Tabela 4.5. Valores médios e coeficiente de variação (CV) da porcentagem de $\left(\mathrm{CH}_{4}\right)$ no biogás e das produções diária, volumétrica e específica de $\mathrm{CH}_{4}$ obtidos durante a operação do sistema em dois estágios, primeiro reator (r1) e segundo reator (r2), nos ensaios 1, 2 e 3.

\begin{tabular}{|c|c|c|c|c|c|c|c|c|c|c|c|c|}
\hline \multirow[t]{3}{*}{ Ensaio } & \multirow{2}{*}{\multicolumn{2}{|c|}{$\begin{array}{r}\text { TDH } \\
\text { (h) }\end{array}$}} & \multirow{2}{*}{\multicolumn{2}{|c|}{$\begin{array}{l}\mathrm{CH}_{4} \\
(\%)\end{array}$}} & \multirow{2}{*}{\multicolumn{2}{|c|}{$\begin{array}{l}\text { Produção diária } \\
\left(\mathrm{L} \mathrm{CH}_{4} \cdot \mathrm{d}^{-1}\right)\end{array}$}} & \multirow{2}{*}{\multicolumn{2}{|c|}{$\begin{array}{l}\text { Prod. volumétrica } \\
\left(\mathrm{L} \mathrm{CH}_{4} \cdot\left(\mathrm{L}_{\text {reator. }}{ }^{-1}\right)^{-1}\right)\end{array}$}} & \multicolumn{4}{|c|}{$\begin{array}{c}\text { Prod. específica } \\
\left(\mathrm{L} \mathrm{CH}_{4 .}\left({\left.\text { g DQO total })^{-1}\right)}\right.\right.\end{array}$} \\
\hline & & & & & & & & & \multicolumn{2}{|c|}{ adicionada } & \multicolumn{2}{|c|}{ removida } \\
\hline & $\mathrm{r} 1$ & $\mathrm{r} 2$ & $\mathrm{r} 1$ & $\mathrm{r} 2$ & $\mathrm{r} 1$ & $\mathrm{r} 2$ & $\mathrm{r} 1$ & $\mathrm{r} 2$ & $\mathrm{r} 1$ & $\mathrm{r} 2$ & $\mathrm{r} 1$ & $\mathrm{r} 2$ \\
\hline 1 & 62 & 16 & 72 & 85 & 17,50 & 1,62 & 0,45 & 0,15 & 0,100 & 0,094 & 0,119 & 0,199 \\
\hline 2 & 31 & 8 & 70 & 74 & 45,50 & 2,67 & 1,17 & 0,25 & 0,136 & 0,063 & 0,160 & 0,173 \\
\hline 3 & 16 & 4 & 72 & 75 & 68,20 & 5,50 & 1,80 & 0,50 & 0,096 & 0,029 & 0,133 & 0,124 \\
\hline $\mathrm{C}$ & 62 & 16 & 2,4 & 4,7 & 24,5 & 42,6 & 24,5 & 38,9 & 30,0 & 85,1 & 25,2 & 100,5 \\
\hline V & 31 & 8 & 1,4 & 4,4 & 6,6 & 22,5 & 6,9 & 23,6 & 14,7 & 47,6 & 18,8 & 69,4 \\
\hline$(\%)$ & 16 & 4 & 0,0 & 0,7 & 9,4 & 18,2 & 8,9 & 20,0 & 10,4 & 34,5 & 15,0 & 32,3 \\
\hline
\end{tabular}

Nos 3 ensaios, no primeiro reator, a porcentagem de $\mathrm{CH}_{4}$ no biogás manteve-se estável, na faixa de $70 \%$, com $\mathrm{CV}$ de $0,0 \%$ a $2,4 \%$ e no segundo reator observou-se decréscimo de $85 \%$ para $74 \%$, com CV de $0,7 \%$ a 4,7 \%, com a diminuição do TDH.

As produções diária e volumétrica de $\mathrm{CH}_{4}$ aumentaram com a diminuição do TDH e aumento da TCOV, variando de 17,50 a 68,20 L CH $4 . \mathrm{d}^{-1}$ e 0,45 a 1,80 $\mathrm{L} \mathrm{CH}_{4}\left(\mathrm{~L}_{\text {reator. }} \mathrm{d}^{-1}\right)$, respectivamente, para o primeiro reator e 1,62 a $5,50 \mathrm{~L} \mathrm{CH}_{4} \cdot \mathrm{d}^{-1}$ e 0,15 a $0,50 \mathrm{~L} \mathrm{CH}_{4}(\mathrm{~L}$ reator. $\mathrm{d}^{-1}$ ) para o segundo reator.

$\mathrm{O}$ primeiro reator apresentou maiores produções específicas de $\mathrm{CH}_{4}$ no ensaio 2, com valores de $0,136 \mathrm{~L} \mathrm{CH}_{4}\left(\mathrm{~g} \mathrm{DQO}_{\text {total }} \text { adicionada }\right)^{-1}$ e $0,160 \mathrm{~L} \mathrm{CH}_{4}\left(\mathrm{~g} \mathrm{DQO}_{\text {total }} \text { removida }\right)^{-1}$. No 
segundo reator as maiores produções específicas foram observadas no ensaio 1, com valores de $0,094 \mathrm{~L} \mathrm{CH}_{4}\left(\mathrm{~g} \mathrm{DQO}_{\text {total }} \text { adicionada }\right)^{-1}$ e $0,199 \mathrm{~L} \mathrm{CH}_{4}\left(\mathrm{~g} \mathrm{DQO}_{\text {total }} \text { removida }\right)^{-1}$.

Oliveira (1997) obteve produções volumétricas de 0,072 a 1,151 $\mathrm{L} \mathrm{CH}_{4}$ ( $\mathrm{L}$ reator.d $^{-1}$ ) com reatores UASB tratando águas residuárias de suinocultura, com $\mathrm{DQO}_{\text {total }}$ de 952 a 4013 mg. $\mathrm{L}^{-1}$ e TDH de 8 a $30 \mathrm{~h}$.

Oliveira (2000) utilizando reatores UASB em série, com TDH de 14,7 h em cada reator, $\mathrm{DQO}_{\text {total }}$ de 2514 a $3252 \mathrm{mg} \cdot \mathrm{L}^{-1}$, no primeiro reator, e temperatura média de 23 a $21^{\circ} \mathrm{C}$, obteve produções volumétricas de 0,393 a $0,589 \mathrm{~m}^{3} \mathrm{CH}_{4}\left(\mathrm{~m}^{3}\right.$ reator.d $\left.\mathrm{d}^{-1}\right)$. Oliveira (2001) utilizando o mesmo sistema, com TDH de 7,3 h em cada reator e concentração de DQO de 3361 e $3731 \mathrm{mg} . \mathrm{L}^{-1}$, obteve produções volumétricas de 0,886 e $0,862 \mathrm{~m}^{3} \mathrm{CH}_{4}\left(\mathrm{~m}^{3}\right.$ reator. $\left.\mathrm{d}^{-1}\right)$, com temperatura média de 19,8 a $24,9^{\circ} \mathrm{C}$.

Comparando os resultados com os valores obtidos por Oliveira (1997, 2000 e 2001), observa-se que as produções de volumétricas de metano também aumentaram de 0,45 a 1,80 $\mathrm{L} \mathrm{CH}_{4}\left(\mathrm{~L}\right.$ reator. $\left.\mathrm{d}^{-1}\right)$, no primeiro reator, e de 0,15 a $0,50 \mathrm{~L} \mathrm{CH}_{4}\left(\mathrm{~L}_{\text {reator. }} \mathrm{d}^{-1}\right)$, no segundo reator, com a diminuição do TDH e conseqüente aumento da TCOV de 4,55 a 18,65 kg DQO. $\mathrm{m}^{3} \cdot \mathrm{d}^{-1}$, com temperatura controlada entre 25 e $30^{\circ} \mathrm{C}$.

Oliveira (1997) obteve maior produção volumétrica de metano, 1,151 $\mathrm{L} \mathrm{CH}_{4}(\mathrm{~L}$ reator. $\left.\mathrm{d}^{-1}\right)$, com temperatura de $30^{\circ} \mathrm{C}$ e TDH de $12 \mathrm{~h}$.

Os $\mathrm{CV}$ das médias apresentadas para as produções diária e volumétrica de $\mathrm{CH}_{4}$ no primeiro reator, no ensaio 1 , foram altos com valores de $24,5 \%$ para ambas as produções. No ensaio 2, os valores de CV permaneceram na faixa de 6,8\% e no ensaio 3 permaneceram abaixo de $10 \%$, indicando maior estabilidade do reator em relação à produção de $\mathrm{CH}_{4}$.

Os $\mathrm{CV}$ das médias das produções diária e volumétrica de $\mathrm{CH}_{4}$ no segundo reator decresceram, respectivamente, de $42,6 \%$ a $18,2 \%$ e $38,9 \%$ a $20,0 \%$ com a diminuição do TDH de $62 \mathrm{~h}$ para $16 \mathrm{~h}$ e aumento da TCOV de 2,55 a 21,03 kg DQO.m ${ }^{3} \cdot \mathrm{d}^{-1}$, ainda apresentando valores altos.

Porém, deve-se considerar que nessas médias estão incluídos valores medidos em períodos onde houve causas de instabilidade dos reatores, como descarte de lodo da manta, as mudanças de TDH, as variações de temperatura no ensaio 1 antes do controle por termômetro e os problemas operacionais observados, principalmente no segundo reator, como a falta de alimentação ocasionada por entupimentos do sistema por períodos superiores a cinco dias, o que acarretava variações na produção de gás.

Na Tabela 4.6 são apresentados, para o primeiro e segundo reatores nos ensaio 1, 2 e 3, os resultados médios de produção diária de metano, juntamente com a TCOV, as DQO 
médias diárias afluentes, efluentes e removidas, os valores calculados das porcentagens de $\mathrm{DQO}_{\text {total }}$ afluente e removida convertidas em metano e a relação entre a produção de DQO-

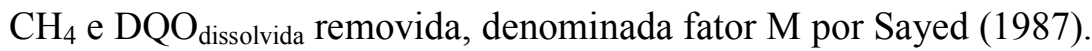

Os valores de $\mathrm{DQO}_{\text {total }}$ do afluente e removida convertidas em metano variaram na média, respectivamente, de 27,1 a $38,4 \%$ e 33,3 a 44,6\%, para o primeiro reator, e de 8,0 a $18,3 \%$ e 27,7 a $35,8 \%$, para o segundo reator, os quais segundo Oliveira (1997), podem ser considerados relativamente baixos. Oliveira (1997) atribuiu os baixos valores obtidos às perdas de gases no separador de fases, além de perdas de metano dissolvido na fase liquida, cuja concentração depende da temperatura e da pressão parcial desse gás na fase gasosa. Segundo Van Haandel e Lettinga ${ }^{3}$ (1994 apud OLIVEIRA, 1997), em virtude das perdas de metano no efluente e para a atmosfera, a produção de metano medida é bem menor que aquela prevista com base em considerações estequiométricas, atingindo na prática valores de 20 a $50 \%$ da produção teórica de metano.

Oliveira (1997) obteve valores de $\mathrm{DQO}_{\text {total }}$ do afluente e removida, convertidas em metano, respectivamente, de 27,4 a $37,2 \%$ e 33,8 a $44,1 \%$, em reator UASB com TCOV de 5,72 a $6,07 \mathrm{~kg} \mathrm{DQO}_{\text {total }} \cdot \mathrm{m}^{-3} \cdot \mathrm{d}^{-1}$ e TDH de $12 \mathrm{~h}$. Comparando-se os valores obtidos com os apresentados por Oliveira (1997), observam-se conversões semelhantes em relação à DQO $_{\text {total }}$ do afluente e $\mathrm{DQO}_{\text {total }}$ removida, no primeiro reator com TCOV variando de 4,55 a $18,65 \mathrm{~kg}$ $\mathrm{DQO}_{\text {total }} \cdot \mathrm{m}^{-3} \cdot \mathrm{d}^{-1}$ e TDH de 62 a $16 \mathrm{~h}$.

Entretanto, o segundo reator apresentou valores inferiores aos obtidos por Oliveira (1997), podendo-se atribuir aos mesmos fatores citados anteriormente, neste item. Deve-se ressaltar que ocorria constantes distúrbios no segundo reator, decorrentes do aumento da velocidade de entrada do efluente do primeiro reator, o que ocasionava entupimentos e revolvimento freqüente da manta de lodo e possivelmente menores conversões de $\mathrm{DQO}_{\text {total }} \mathrm{e}$ removida a metano.

Observa-se na Tabela 5.6 que a relação $\mathrm{DQO}-\mathrm{CH}_{4}$ por $\mathrm{DQO}_{\text {dissolvida }}$ removida variou de 1,12 a 1,69, no primeiro reator, e de 2,88 a 3,45, no segundo reator. Os valores observados no segundo reator foram maiores do que no primeiro reator, podendo-se atribuir as menores TCOV em relação a $\mathrm{DQO}_{\text {dissolvida }}$ e também as possíveis maiores taxas de hidrólise ocorridas no segundo reator, conduzindo ao maior consumo de compostos solúveis formados, evitandose acúmulos.

\footnotetext{
${ }^{3}$ VAN HAANDEL, A.C, LETTINGA, G. (1994). Tratamento anaeróbio de esgotos - Um manual para regiões de clima quente. Campina Grande-PB, Epgraf.
} 
Utilizando-se procedimento adotado por Oliveira (1997), conforme apresentado na Tabela 4.7, observam-se eficiências de remoção física decrescentes para o primeiro e segundo reatores. Com o controle da temperatura média de operação entre 25 e $30^{\circ} \mathrm{C}$ nos ensaios do experimento, evidenciando a melhoria nas condições de hidrólise e metanogênese, verificouse a diminuição na remoção física nos reatores e, conseqüentemente, a acumulação de lodo na manta por este mecanismo.

Ressalta-se, porém, que o segundo reator no ensaio 3, apresentou maior remoção física de lodo, possivelmente ao baixo TDH aplicado diminuindo a hidrólise dos sólidos retidos. 


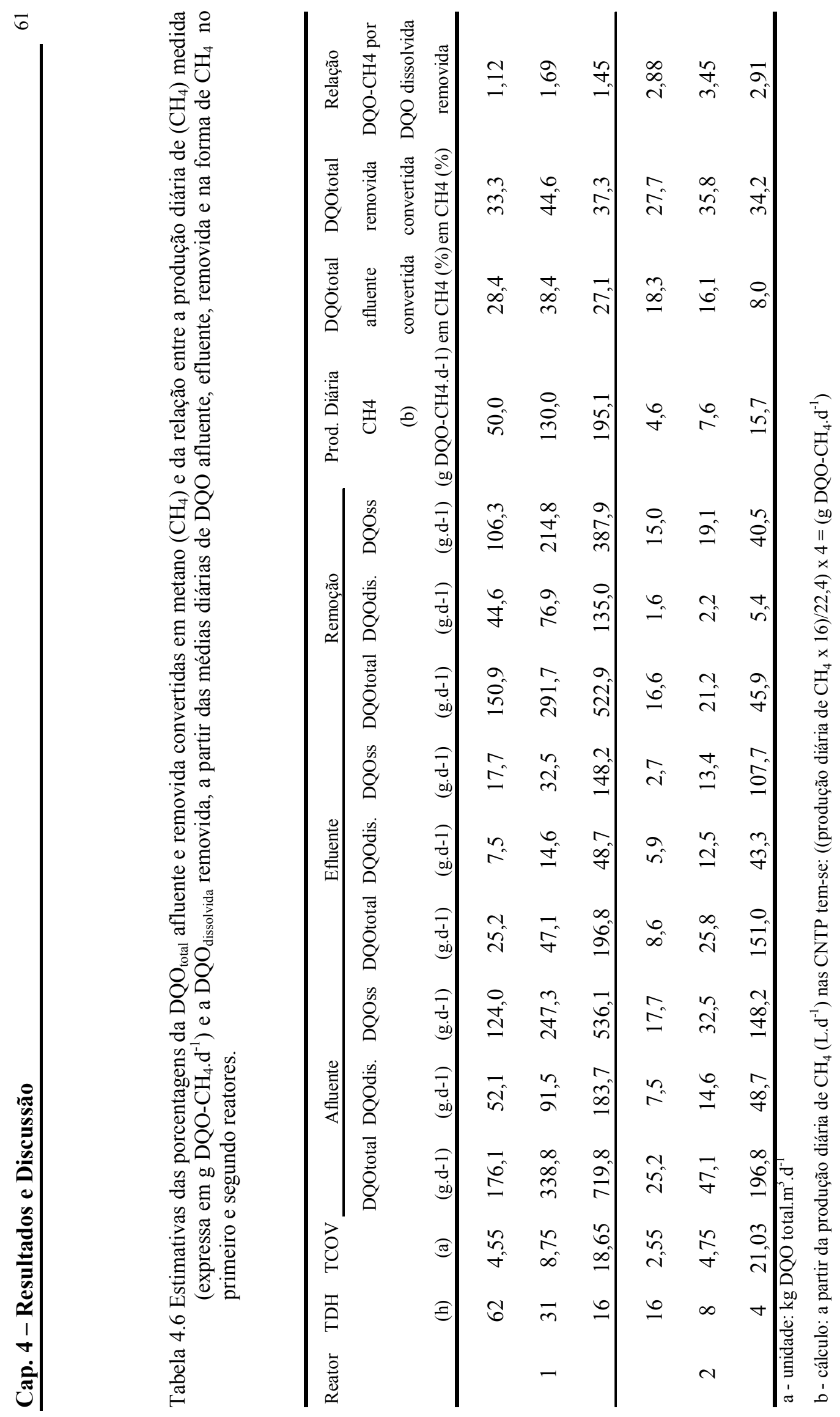




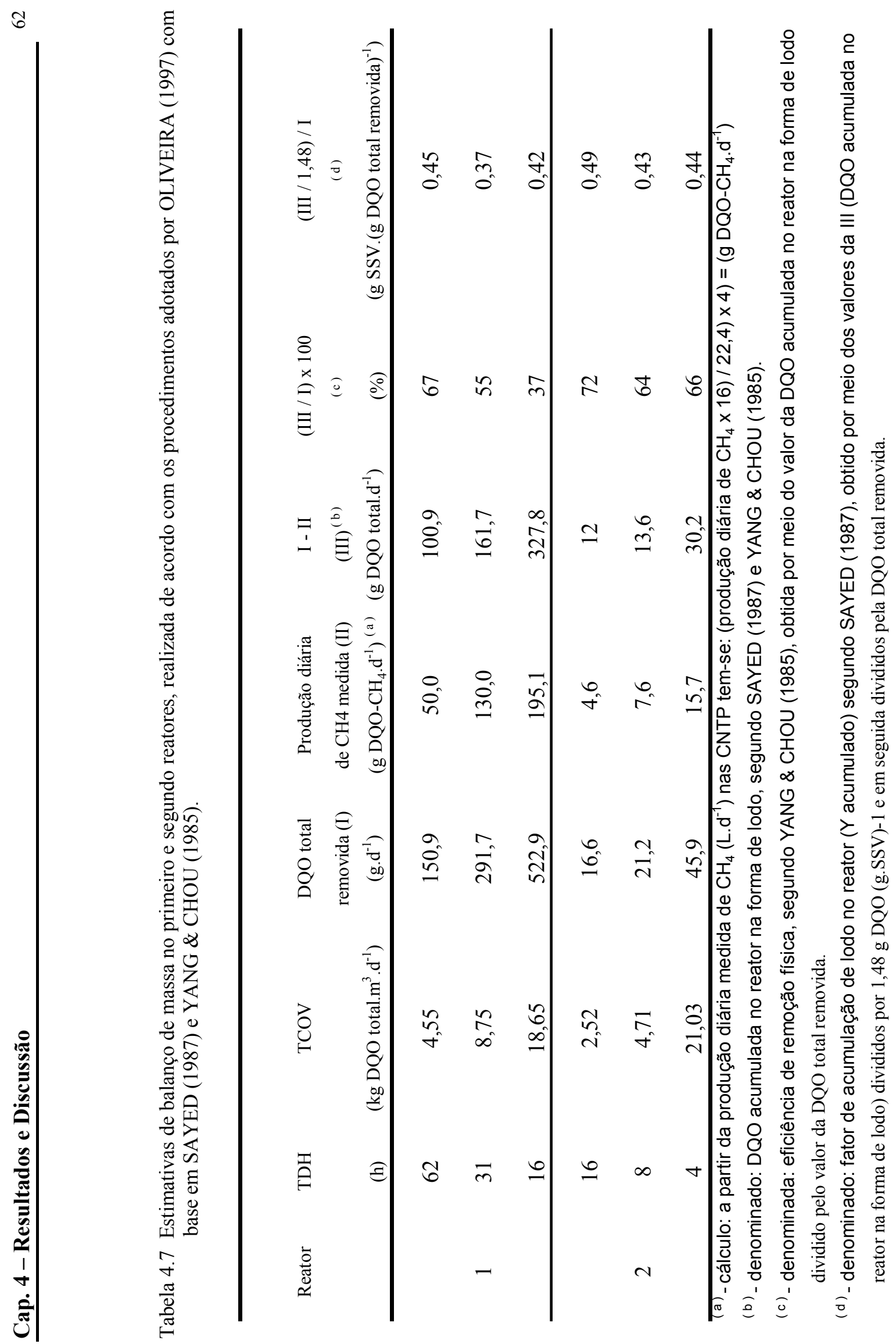




\subsubsection{Lodo - produção e taxa de acumulação na manta}

Considerando-se os resultados de conversão de DQO em metano, o efeito da temperatura e de altas concentrações de SST no afluente sobre o crescimento da manta de lodo, e da mesma forma que foi evidenciado por Sayed ${ }^{4}$ (1987 apud OLIVEIRA, 1997) e Yang e Chou $^{5}$ (1985 apud OLIVEIRA, 1997), ressalta-se a importância da acumulação de lodo nos reatores. Na Tabela 4.8 estão apresentados os resultados médios de $\mathrm{Y}$ acumulado obtidos por meio do balanço de massa do lodo de excesso, descartado durante a operação dos reatores no sistema em dois estágios nos ensaios 1,2 e 3.

Tabela 4.8. Balanço de massa para determinação do fator de acumulação de lodo (Y acumulado) no primeiro e segundo reatores durante a operação do sistema em dois estágios, nos ensaios 1,2 e 3 .

\begin{tabular}{|c|c|c|c|c|c|c|c|c|c|c|}
\hline \multirow[t]{3}{*}{ Reator } & \multirow[t]{3}{*}{ Ensaio } & \multirow{3}{*}{$\begin{array}{l}\text { TDH } \\
\text { (h) }\end{array}$} & \multirow{2}{*}{\multicolumn{2}{|c|}{$\begin{array}{c}\text { DQO } \\
\left(\mathrm{mg} . \mathrm{L}^{-1}\right) \\
\end{array}$}} & \multirow{3}{*}{$\begin{array}{l}\text { T. oper. } \\
\text { (d) }\end{array}$} & \multicolumn{2}{|c|}{ Lodo descarte } & \multirow{2}{*}{\multicolumn{2}{|c|}{$\begin{array}{c}\text { SSV } \\
\left(\mathrm{mg} \cdot \mathrm{L}^{-1}\right) \\
\end{array}$}} & \multirow{3}{*}{$\begin{array}{c}\text { Y acumulado } \\
(*)\end{array}$} \\
\hline & & & & & & (L) & $\left(\mathrm{mg} \cdot \mathrm{L}^{-1}\right)$ & & & \\
\hline & & & afluente & efluente & & & & afluente & efluente & \\
\hline \multirow{3}{*}{$\mathrm{r} 1$} & 1 & 62 & 11740 & 1681 & 46 & 16 & 515 & 4740 & 830 & 0,220 \\
\hline & 2 & 31 & 11292 & 1569 & 59 & 40 & 1218 & 4600 & 730 & 0,205 \\
\hline & 3 & 16 & 12306 & 3365 & 41 & 30 & 945 & 5000 & 1700 & 0,340 \\
\hline \multirow{3}{*}{$\mathrm{r} 2$} & 1 & 16 & 1681 & 574 & 46 & 5 & 173 & 830 & 260 & 0,647 \\
\hline & 2 & 8 & 1569 & 861 & 59 & 11 & 281 & 730 & 510 & 1,365 \\
\hline & 3 & 4 & 3365 & 2581 & 41 & 5 & 125 & 1700 & 1320 & 2,581 \\
\hline
\end{tabular}

O fator de acumulação de lodo no reator (Y acumulado) foi obtido a partir do valor da concentração de sólidos suspensos voláteis (SSV) no efluente e sólidos voláteis (SV) no lodo de descarte, proveniente do primeiro e segundo reatores. $\mathrm{O}$ cálculo foi obtido a partir da expressão 1:

4 SAYED, S.K.I. (1987). Anaerobic treatment of slaughterhouse wastewater using the UASB process. Wageningen - The Netherlands. 1987, 134p., Tese (Ph.D) - Wageningen Agricultural University.

5 YANG, P.Y., CHOU, C.Y. (1985). Horizontal-bafled anaerobic reactor treating diluted swine wastewater. Agricultural Wastes, v.14, p.221-239. 


$$
Y_{\text {obs }}=\frac{\left(Q^{*} S S V_{\text {efluente }} * t_{\text {operação }}+V_{\text {lodo }} * S V T^{*} f_{\text {correção }}\right) * 1,48}{Q *\left(D Q O_{\text {afluente }}-D Q O_{\text {efluente }}\right) * t_{\text {operação }}}
$$

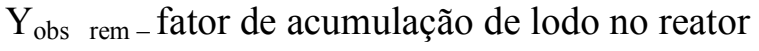

Q - vazão afluente

$\mathrm{SSV}_{\text {efluente }}$ - sólidos suspensos voláteis no efluente

$\mathrm{T}_{\text {operação }}$ - tempo de operação do ensaio

SVT - sólidos voláteis totais do lodo

$\mathrm{f}_{\text {correção }}$ - fator de correção $(0,9)$

$1,48$ - g DQO.(g SSV $)^{-1}$

No procedimento adotado não foi executado o balanço global de lodo para o sistema, pois o aporte de sólidos nos reatores foi elevado, inviabilizando o cálculo da produção de lodo. Neste sentido, optou-se por considerar na determinação de Y acumulado apenas o lodo de excesso. A determinação do valor de $\mathrm{Y}$ acumulado foi executado de acordo com a cinética da produção microbiana e utilização do substrato, expresso em termos da DQO removida.

Os valores de $\mathrm{Y}$ acumulado obtidos em relação a DQO removida, para o primeiro reator $\left(0,20\right.$ a $\left.0,34 \mathrm{~g} \mathrm{SSV} .(\mathrm{g} \text { DQO removida) })^{-1}\right)$, foram menores que os valores de $\mathrm{Y}$ acumulado estimados $(0,37 \text { a } 0,45 \text { g SSV.(g DQO removida) })^{-1}$ (Tabela 4.7) para a produção de lodo a partir dos valores da produção de metano.

Estes valores foram menores devido, provavelmente, a valores subestimados da produção de metano, ocasionada por perdas de gás por meio de vazamentos, com o efluente e para a atmosfera, aprisionamento na manta de lodo e arraste do sistema, as quais não foram incluídas nas estimativas de rendimento de lodo acumulado na manta e não foram analisadas durante o desenvolvimento do estudo. Ainda, parte dos sólidos podem ter sido hidrolisados e não foram computados no balanço, além de não ter sido considerado no cálculo de $\mathrm{Y}$ acumulado a energia necessária para a manutenção celular.

Em virtude dos aspectos apresentados, a estimativa de um balanço de massa global com boa confiabilidade nos parâmetros considerados fica bastante prejudicada, em conseqüência da adoção de premissas não totalmente verdadeiras. Assim, a obtenção de conclusões mais definitivas sobre o destino das frações componentes das águas residuárias com altas concentrações de SST fica impossibilitada (OLIVEIRA, 1997). 
Wang $^{6}$ (1994 apud OLIVEIRA, 1997) apresentou preocupações neste sentido e destacou que suas estimativas de balanço de massa foram grosseiras, em conseqüência dos erros inevitáveis nas amostragens de lodo para medidas dos perfis da manta e do lodo descartado, conseqüentemente, nos cálculos dos parâmetros.

As preocupações de Oliveira (1997) e Wang ${ }^{6}$ (1994 apud Oliveira, 1997) também podem ser estendidas para este estudo. Contudo, os resultados obtidos foram bastante úteis para avaliações e comparações de desempenho dos reatores UASB utilizados no tratamento das águas residuárias de suinocultura com altas concentrações de SST, permitindo observar uma remoção efetiva de sólidos no sistema, não apenas devido à retenção física, mas também pela solubilização das partículas e consumo pela biomassa presente nos reatores.

No segundo reator os valores de Y acumulado observados aumentaram de 0,64 a 2,58 g SSV.(g DQO total removida) $^{-1}$ com a diminuição do TDH, podendo-se atribuir, além dos aspectos citados para o primeiro reator, ao arraste de sólidos do reator devido a maior velocidade ascensional (de 0,048 a 0,193 $\mathrm{m} / \mathrm{h}$ ) aplicada, evidenciado pelo aumento da participação de sólidos suspensos no efluente do segundo reator (Tabela 4.2) e conseqüente redução da eficiência de remoção de SSV.

Segundo Chernicharo (1997), para reatores operando com lodo tipo floculento e com cargas orgânicas de até 5 a $6 \mathrm{~kg}$ DQO. $\mathrm{m}^{-3} \cdot \mathrm{d}^{-1}$, as velocidades superficiais médias devem ser da ordem de 0,5 a $0,7 \mathrm{~m} / \mathrm{h}$. Para reatores operando com lodo tipo granular, as velocidades superficiais podem ser da ordem de até $10 \mathrm{~m} / \mathrm{h}$. O autor cita velocidades superficiais máximas, para reatores UASB tratando esgotos domésticos, de 0,9 a $1,1 \mathrm{~m} / \mathrm{h}$.

As velocidades superficiais obtidas no primeiro e segundo reatores estão abaixo da faixa indicada por Chernicharo (1997). No entanto, a taxa de carregamento orgânico (TCOV) aplicada no segundo reator, no ensaio 3 , foi de $21,03 \mathrm{~kg}$ DQO. $\mathrm{m}^{-3} \cdot \mathrm{d}^{-1}$, o que, provavelmente, tenha contribuído para o arraste de sólidos do reator e conseqüente aumento dos valores de Y acumulado calculados.

\subsubsection{Nitrogênio total, orgânico e amoniacal}

Na Tabela 4.9 estão apresentados os valores médios e o coeficiente de variação $(\mathrm{CV})$ das concentrações de nitrogênio total (NTK), nitrogênio amoniacal $\left(\mathrm{N}_{\mathrm{am}}\right)$, nitrogênio orgânico $\left(\mathrm{N}_{\text {org. }}\right)$ do afluente e efluente e das eficiências de remoção (E) de NTK e $\mathrm{N}_{\text {org. }}$, obtidos durante

\footnotetext{
${ }^{6}$ WANG, K. (1994). Integrated anaerobic and aerobic treatment of swage. Wageningen - The Netherlands, 1994. 145p., Tese (Ph.D) - Wageningen Agricultural University.
} 
a operação do sistema em dois estágios, no primeiro (r1) e segundo (r2) reatores, nos ensaios 1,2 e 3 .

Tabela 4.9. Valores médios e coeficiente de variação (CV) das concentrações de nitrogênio total kjeldahl (NTK), nitrogênio amoniacal $\left(\mathrm{N}_{\mathrm{am}}\right)$, nitrogênio orgânico ( $\left.\mathrm{N}_{\mathrm{org}}\right)$, no afluente $\mathrm{e}$ efluente, e eficiência de remoção (E) de NTK e $\mathrm{N}_{\text {org. }}$ obtidos durante a operação do sistema em dois estágios, primeiro (r1) e segundo (r2) reatores, nos ensaios 1,2 e 3.

\begin{tabular}{|c|c|c|c|c|c|c|c|c|c|c|c|c|c|c|c|c|c|}
\hline \multirow[t]{3}{*}{ Ensaio } & \multirow{2}{*}{\multicolumn{2}{|c|}{$\begin{array}{c}\text { TDH } \\
\text { (h) }\end{array}$}} & \multicolumn{5}{|c|}{$\begin{array}{c}\text { NTK } \\
\left(\mathrm{mg} \mathbf{L}^{-1}\right) \\
\end{array}$} & \multicolumn{3}{|c|}{$\begin{array}{l}\text { N-am. } \\
\left(\mathbf{m g} \cdot L^{-1}\right)\end{array}$} & \multicolumn{5}{|c|}{$\begin{array}{l}\text { N-org. } \\
\left(\mathrm{mg.L} \mathbf{L}^{-1}\right)\end{array}$} & \multirow{3}{*}{$\begin{array}{c}\text { NTK } \\
\text { sistema } \\
E(\%) \\
r 1+r 2\end{array}$} & \multirow{3}{*}{$\begin{array}{c}\text { N-org. } \\
\text { sistema } \\
E(\%) \\
r 1+r 2\end{array}$} \\
\hline & & & \multirow[t]{2}{*}{ afl. } & \multicolumn{2}{|c|}{ efluente } & \multicolumn{2}{|c|}{ E (\%) } & \multirow[t]{2}{*}{ afl. } & \multicolumn{2}{|c|}{ efluente } & \multirow[t]{2}{*}{ afl. } & \multicolumn{2}{|c|}{ efluente } & \multicolumn{2}{|c|}{$\mathrm{E}(\%)$} & & \\
\hline & $\mathrm{r} 1$ & $\mathrm{r} 2$ & & $\mathrm{r} 1$ & $\mathrm{r} 2$ & $\mathrm{r} 1$ & $\mathrm{r} 2$ & & $\mathrm{r} 1$ & $\mathrm{r} 2$ & & $\mathrm{r} 1$ & $\mathrm{r} 2$ & $\mathrm{r} 1$ & $\mathrm{r} 2$ & & \\
\hline 1 & 62 & 16 & 455 & 397 & 357 & 13 & 10 & 255 & 306 & 336 & 205 & 95 & 25 & 54 & 74 & 22 & 88 \\
\hline 2 & 31 & 8 & 443 & 388 & 354 & 12 & 9 & 191 & 277 & 313 & 270 & 123 & 49 & 55 & 60 & 20 & 82 \\
\hline 3 & 16 & 4 & 491 & 445 & 407 & 9 & 9 & 227 & 341 & 350 & 273 & 111 & 64 & 60 & 42 & 17 & 76 \\
\hline $\mathrm{C}$ & 62 & 16 & 1,1 & 1,3 & 1,7 & 6 & 10,1 & 2,0 & 1,8 & 1,8 & 2,5 & 5,6 & 17,4 & 2,7 & 4,2 & 3,0 & 2,0 \\
\hline V & 31 & 8 & 2,4 & 2,5 & 3,5 & 1,2 & 11,1 & 8,9 & 4,1 & 3,5 & 3,7 & 8,0 & 18,4 & 3,6 & 7,0 & 4,6 & 3,3 \\
\hline$(\%)$ & 16 & 4 & 2,0 & 3,2 & 1,8 & 11,2 & 17,8 & 4,1 & 3,0 & 2,1 & 3,0 & 7,6 & 11,6 & 3,2 & 5,8 & 3,4 & 2,7 \\
\hline
\end{tabular}

Nos ensaios 1, 2 e 3 os valores médios de NTK e $N_{a m}$ observados no afluente foram de 443 a $491 \mathrm{mg} . \mathrm{L}^{-1}$ e de 191 a $255 \mathrm{mg} . \mathrm{L}^{-1}$, respectivamente. O N $\mathrm{N}_{\text {org. }}$ apresentou valores médios de 205 a $273 \mathrm{mg} \cdot \mathrm{L}^{-1}$.

No efluente do primeiro reator os valores médios de NTK e $\mathrm{N}_{\mathrm{am}}$. decresceram, com a diminuição do TDH de 62 a 31 h, de 397 para 388 mg.L $\mathrm{L}^{-1}$ e 306 para 277 mg. $\mathrm{L}^{-1}$, respectivamente, e os valores de $\mathrm{N}_{\text {org. }}$ aumentaram de 95 para $123 \mathrm{mg} . \mathrm{L}^{-1}$. No ensaio 3 , com TDH de 16 h, observou-se acréscimo dos valores médios de NTK para $491 \mathrm{mg} . \mathrm{L}^{-1}$ e $\mathrm{N}_{\text {org. }}$. em relação ao ensaio 2 , para $227 \mathrm{mg} \cdot \mathrm{L}^{-1}$. O N $\mathrm{am}$. no ensaio 3 decresceu, em relação ao ensaio 2 , para $111 \mathrm{mg} . \mathrm{L}^{-1}$.

Nos ensaios 1 e 2, no efluente do segundo reator, os valores médios de NTK e $\mathrm{N}_{\mathrm{am}}$. diminuíram de 357 para $354 \mathrm{mg} . \mathrm{L}^{-1}$ e 336 para $313 \mathrm{mg} . \mathrm{L}^{-1}$, respectivamente, e aumentaram, no ensaio 3, para 445 e $350 \mathrm{mg} . \mathrm{L}^{-1}$. Os valores médios de $\mathrm{N}_{\text {org. }}$ aumentaram de 25 para 64 mg. $\mathrm{L}^{-1}$ na diminuição do TDH. Isto pode estar associado às alterações na composição da água residuária afluente e também à redução verificada na remoção de $\mathrm{N}_{\text {org. }}$ com a diminuição do 
TDH. A amonificação do $\mathrm{N}_{\text {org. }}$ ocasionou os acréscimos nos valores médios de $\mathrm{N}_{\mathrm{am}}$. para TDH de $16 \mathrm{~h}$.

As remoções médias de NTK variaram de 9 a 13\% no primeiro reator e de 9 a $12 \%$ no segundo reator com a diminuição do TDH. Os valores médios de remoção do $\mathrm{N}_{\text {org. }}$ variaram, no primeiro e segundo reatores, respectivamente, de 54 a $60 \%$ e 42 a $74 \%$. As remoções médias de NTK e $\mathrm{N}_{\mathrm{am}}$. observadas no sistema foram, respectivamente, de 17 a $22 \%$ e 76 a $88 \%$.

Oliveira (1997) obteve eficiências de remoção de NTK e $\mathrm{N}_{\text {org., }}$ com temperatura controlada de 25 e $30^{\circ} \mathrm{C}$, respectivamente, de 28 e $31 \%$ e 90 e 95\%, com TDH de $12 \mathrm{~h}$. Trabalhando à temperatura ambiente obteve maiores eficiências de remoção de NTK, variando entre 30 e $35 \%$, com TDH de 12 h. O autor observou, também, que o aumento na eficiência de remoção de NTK esteve relacionada com o aumento da TCOV e concentração de SST no afluente, atingindo maior valor de remoção com TCOV em torno de $6 \mathrm{~kg}$ $\mathrm{DQO}_{\text {total }} \cdot \mathrm{m}^{-3} \cdot \mathrm{d}^{-1}$.

Comparando-se os resultados, com os obtidos por Oliveira (1997), verifica-se que as eficiências de remoção de NTK são menores e apresentaram tendência de redução com o aumento da TCOV. De acordo com Sayed ${ }^{7}$ (1987 apud OLIVEIRA, 1997), o processo anaeróbio é ineficiente para a redução de NTK, sendo a remoção decorrente da imobilização bacteriana para crescimento.

Conforme constatado por Oliveira (1997) e também observado neste estudo, a concentração de $\mathrm{N}_{\mathrm{am}}$. no efluente não aumentou proporcionalmente a amonificação do $\mathrm{N}_{\text {org. }}$, refletindo as alterações na concentração de $\mathrm{N}_{\mathrm{am}}$. no afluente. Conseqüentemente, isto indicou que maior quantidade de $\mathrm{N}_{\text {org. }}$ removido ficou retido na biomassa dos reatores (OLIVEIRA, 1997).

Segundo Singh et al. (1999), concentrações de nitrogênio inferiores a $300 \mathrm{mg} \cdot \mathrm{L}^{-1}$ provocam reduções drásticas no crescimento celular e concentrações superiores a $1000 \mathrm{mg} . \mathrm{L}^{-1}$ de $\mathrm{N}_{\mathrm{am}}$. inibiram a granulação em reatores UASB. Ainda, segundo os autores, para águas residuárias domésticas, concentrações de $\mathrm{N}_{\mathrm{am}}$. superiores a $1200 \mathrm{mg} . \mathrm{L}^{-1}$ são tóxicas aos microrganismos dependendo do $\mathrm{pH}$.

Portanto, através dos resultados obtidos verifica-se que as concentrações de NTK e $\mathrm{N}_{\mathrm{am}}$. estão dentro da faixa de valores relatada por Singh et al. (1999).

\footnotetext{
7 SAYED, S.K.I. (1987). Anaerobic treatment of slaughterhouse wastewater using the UASB process. Wageningen - The Netherlands. 1987, 134p., Tese (Ph.D) - Wageningen Agricultural University.
} 


\subsubsection{Fósforo total}

Na Tabela 4.10 estão apresentados os valores médios e o coeficiente de variação $(\mathrm{CV})$ das concentrações de fósforo total $\left(\mathrm{P}_{\text {total }}\right)$, no afluente e efluente, e eficiência de remoção $(\mathrm{E})$, obtidos durante a operação dos reatores em dois estágios nos ensaios 1, 2 e 3 do experimento.

Tabela 4.10. Valores médios e coeficiente de variação $(\mathrm{CV})$ da concentração de fósforo total $\left(\mathrm{P}_{\text {total }}\right)$, no afluente e efluente, e eficiência de remoção (E) obtidos durante a operação do sistema em dois estágios, primeiro (r1) e segundo (r2) reatores, nas fases 1 e 2 .

\begin{tabular}{|c|c|c|c|c|c|c|c|c|c|c|}
\hline \multirow[t]{3}{*}{ Ensaio } & \multicolumn{2}{|c|}{$\begin{array}{c}\text { TDH } \\
\text { (h) }\end{array}$} & \multicolumn{3}{|c|}{ reator 1} & \multirow[t]{3}{*}{ P-total } & \multicolumn{3}{|c|}{$\left(\mathrm{mg} \cdot \mathrm{L}^{-1}\right)$} & \multirow{3}{*}{$\begin{array}{c}\text { sistema } \\
\mathrm{E}(\%) \\
\mathrm{r} 1+\mathrm{r} 2 \\
\end{array}$} \\
\hline & & & \multirow[t]{2}{*}{ afl. } & \multirow[t]{2}{*}{ efluente } & \multirow[t]{2}{*}{ E (\%) } & & \multirow[t]{2}{*}{ afl. } & \multirow[t]{2}{*}{ efluente } & \multirow[t]{2}{*}{$\mathrm{E}(\%)$} & \\
\hline & $\mathrm{r} 1$ & $\mathrm{r} 2$ & & & & & & & & \\
\hline 1 & 62 & 16 & 127 & 76 & 39 & & 76 & 50 & 34 & 60 \\
\hline 2 & 31 & 8 & 157 & 97 & 38 & & 97 & 60 & 38 & 62 \\
\hline 3 & 16 & 4 & 151 & 88 & 41 & & 88 & 77 & 12 & 48 \\
\hline $\mathrm{C}$ & 62 & 16 & 19,7 & 8,4 & 43,8 & & 8,4 & 8,7 & 33,1 & 7,3 \\
\hline V & 31 & 8 & 6,2 & 1,5 & 12,6 & & 1,5 & 20,8 & 36,4 & 9,0 \\
\hline$(\%)$ & 16 & 4 & 37,0 & 36,1 & 22,0 & & 36,1 & 35,3 & 25,0 & 14,6 \\
\hline
\end{tabular}

Nos ensaios 1 e 2 observou-se que os valores médios de $\mathrm{P}_{\text {total }}$ no afluente variaram de $127 \mathrm{mg} . \mathrm{L}^{-1}$ a $157 \mathrm{mg} . \mathrm{L}^{-1}$ e no efluente, do primeiro e segundo reatores, de $76 \mathrm{mg} . \mathrm{L}^{-1}$ a 97 mg. $\mathrm{L}^{-1}$ e $50 \mathrm{mg} . \mathrm{L}^{-1}$ a $60 \mathrm{mg} . \mathrm{L}^{-1}$, respectivamente, apresentando ambos tendência de aumento com a diminuição do TDH. No ensaio 3, o valor médio do efluente do primeiro reator sofreu pequeno decréscimo para $88 \mathrm{mg} . \mathrm{L}^{-1}$ e no segundo reator houve aumento para $77 \mathrm{mg} . \mathrm{L}^{-1}$. O coeficiente de variação $(\mathrm{CV})$ para o efluente do primeiro reator variou de $1,5 \%$ a $36,1 \%$ e do segundo reator de 8,7 a $35,3 \%$.

A eficiência de remoção de $\mathrm{P}_{\text {total }}$ no primeiro reator foi semelhante nos ensaios 1,2 e 3, variando de $38 \%$ a $41 \%$. No segundo reator a eficiência de remoção aumentou de $34 \%$ a 38\% com a diminuição do TDH, no ensaio 1 e 2 , e apresentou queda para $12 \%$ no ensaio 3 . A eficiência de remoção do sistema variou na média de $48 \%$ a $62 \%$ com coeficiente de variação de $7,3 \%$ a $14,6 \%$. 
Pereira-Ramirez et al. (2003) observaram eficiência de remoção de $\mathrm{P}_{\text {total }}$ de $60 \%$ em sistema combinado, composto por um reator UASB, Filtro Anaeróbio, Reator Anóxico e Contactor Biológico Rotatório. Os autores atribuíram a remoção do nutriente por ação biológica por meio do metabolismo celular e adsorção pela biomassa, através do sistema. Oliveira (1997) obteve eficiência de remoção de $\mathrm{P}_{\text {total }}$ de 8 a 23\%, em reator UASB tratando água residuária de suinocultura, com temperatura de 25 e $30^{\circ} \mathrm{C}$ e TDH de $12 \mathrm{~h}$.

Comparando-se os resultados, verifica-se eficiência de remoção de $\mathrm{P}_{\text {total }}$ semelhante à obtida por Pereira-Ramirez et al. (2003), nos ensaios 1 e 2 e superior a observada por Oliveira (1997), nos três ensaios do experimento.

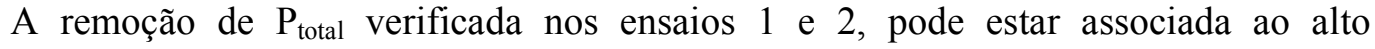
crescimento da manta, sendo incorporado pela biomassa (PEREIRA-RAMIREZ et al., 2003) e também pela retenção de sólidos no sistema. Além disso, existe a possibilidade de parte deste fósforo ter sido removido por meio de precipitação, conforme observado por Oliveira (1997). O autor verificou a presença de precipitados incrustados nas paredes de grânulos, analisados por meio de EDX, com a presença constante de P na sua constituição. Entretanto, no ensaio 3, a queda de eficiência, provavelmente, ocorreu devido ao maior arraste de sólidos observados nos efluentes dos reatores.

\subsubsection{0. $\mathrm{pH}$, alcalinidade e ácidos voláteis}

$\mathrm{Na}$ Tabela 4.11 estão apresentados os valores médios e o coeficiente de variação $(\mathrm{CV})$ do $\mathrm{pH}$, alcalinidade total (AT), parcial (AP) e intermediária (AI), concentração de ácidos voláteis totais (AVT) do afluente e efluente, relações AI:AP e AVT:AT no efluente obtidos durante a operação dos reatores em dois estágios nos ensaios 1, 2 e 3 do experimento. Os resultados utilizados para o cálculo dos valores médios, obtidos durante os ensaios, estão apresentados nas Figuras 4.22, 4.23, 4.24, 4.25, 4.26, 4.27 e 4.28.

No primeiro reator, observou-se que o $\mathrm{pH}$ no afluente apresentou valores médios de 7,33; 7,12 e 7,16 para TDH de 62 h, 31 h e 16 h, respectivamente. No efluente os valores decresceram de 7,79 a 7,52 com a diminuição do TDH de 62 a 16 h, com coeficiente de variação de $1,3 \%$ a $2,9 \%$.

A alcalinidade total, parcial e intermediária no afluente apresentou variação de 950 a $689 \mathrm{mg} . \mathrm{L}^{-1}, 318$ a $267 \mathrm{mg} . \mathrm{L}^{-1}$ e de 631 a $422 \mathrm{mg} . \mathrm{L}^{-1}$, respectivamente, nos ensaios 1 e 2 . No ensaio 3, com TDH de $16 \mathrm{~h}$, os valores de AT, AP e AI apresentaram valores médios de 825 mg.L $\mathrm{L}^{-1}, 302 \mathrm{mg} . \mathrm{L}^{-1}$ e $523 \mathrm{mg} . \mathrm{L}^{-1}$, respectivamente. 
No efluente do primeiro reator observou-se decréscimo de AT, AP e AI, na diminuição do TDH de $62 \mathrm{~h}$ a $31 \mathrm{~h}$ e aumento da TCOV de 4,55 a 8,75 kg DQO.m ${ }^{-3} \cdot \mathrm{d}^{-1}$, de 1714 para $1470 \mathrm{mg} . \mathrm{L}^{-1}, 1290$ para $1098 \mathrm{mg} . \mathrm{L}^{-1}$ e 424 para $372 \mathrm{mg} . \mathrm{L}^{-1}$, respectivamente. No ensaio 3, TDH de 16 h e TCOV de 18,65 kg DQO. $\mathrm{m}^{-3} \cdot \mathrm{d}^{-1}$, observou-se pequeno aumento na AT e AP, em relação ao ensaio 2, para $1529 \mathrm{mg} . \mathrm{L}^{-1}$ e $1195 \mathrm{mg} . \mathrm{L}^{-1}$, respectivamente, e redução no valor de AI para 334 mg.L ${ }^{-1}$.

A concentração de ácidos voláteis totais no afluente do primeiro reator variou de 767 a $1148 \mathrm{mg} . \mathrm{L}^{-1}$ e no efluente houve diminuição de 156 para $128 \mathrm{mg} . \mathrm{L}^{-1}$ mesmo com a diminuição do TDH e aumento da TCOV de 4,55 a 18,65 kg DQO.m ${ }^{-3} \cdot \mathrm{d}^{-1}$, indicando estabilidade com geração de alcalinidade, melhorando a capacidade de tamponamento do reator e não permitindo o acúmulo de ácidos voláteis.

A relação AI:AP variou de 0,28 a 0,36 e AVT:AT de 0,08 a 0,09 com a diminuição do TDH e aumento da TCOV.

No segundo reator, o pH do efluente decresceu de 7,97 para 7,74 com a diminuição do $\mathrm{TDH}$ e aumento da TCOV, mantendo-se maior que o $\mathrm{pH}$ do efluente do primeiro reator. $\mathrm{O}$ coeficiente de variação (CV) foi de $1,3 \%$ a 2,0\%.

Observou-se decréscimo nas alcalinidades total, parcial e intermediária no efluente do segundo reator, com a diminuição do TDH de $62 \mathrm{~h}$ a $31 \mathrm{~h}$ e aumento da TCOV de 2,55 a 4,75 kg DQO.m ${ }^{-3} \cdot \mathrm{d}^{-1}$, de $1693 \mathrm{mg} . \mathrm{L}^{-1}$ para $1430 \mathrm{mg} \cdot \mathrm{L}^{-1}, 1318 \mathrm{mg} \cdot \mathrm{L}^{-1}$ para $1068 \mathrm{mg} . \mathrm{L}^{-1}$ e de 376 mg. $\mathrm{L}^{-1}$ para $361 \mathrm{mg} . \mathrm{L}^{-1}$, respectivamente. No ensaio 3 , TDH de $16 \mathrm{~h}$ e TCOV de $21,03 \mathrm{~kg}$ DQO. $\mathrm{m}^{-3} \cdot \mathrm{d}^{-1}$, os valores de AT e AP aumentaram para $1502 \mathrm{mg} . \mathrm{L}^{-1}$ e $1182 \mathrm{mg} . \mathrm{L}^{-}$ ${ }^{1}$,respectivamente, e AI apresentou redução para $320 \mathrm{mg} . \mathrm{L}^{-1}$.

A concentração de ácidos voláteis totais no efluente do segundo reator aumentou de 96 mg. $\mathrm{L}^{-1}$ para 113 mg. $\mathrm{L}^{-1}$ com a diminuição do TDH de 16 a $4 \mathrm{~h}$ e aumento da TCOV de 2,55 a $21,03 \mathrm{~kg}$ DQO. $\mathrm{m}^{-3} \cdot \mathrm{d}^{-1}$. As relações AI:AP e AVT:AT variaram de 0,28 a 0,34 e de 0,06 a 0,08 , respectivamente.

Oliveira (1997) obteve valores de $\mathrm{pH}$ no efluente na faixa de 7,2 a 7,6 e observou decréscimo nos valores de AT, AP e AI com a diminuição do TDH. Observou valores de AVT sempre baixos no efluente (menores que $100 \mathrm{mg} . \mathrm{L}^{-1}$ ) e relações AI:AP e AVT:AT com valores médios máximos de 0,40 a 0,45 e 0,12 a 0,18 , respectivamente. $\mathrm{O}$ autor atribuiu os maiores valores da relação AI:AP para os menores TDH estudados e associou à diminuição na alcalinidade devido à concentração de bicarbonato, relacionada com AP, e aumento na alcalinidade devido à concentração de ácidos voláteis, relacionada com AI, ocasionando queda da eficiência dos reatores. 
Segundo Ripley et al. (1986), o valor de relação AI:AP de 0,30 e de AVT:AT de 0,10 a 0,35 é típica de digestores operados em condições de equilíbrio.

Comparando-se os resultados, houve tendência de diminuição de AT, AP e AI com a diminuição do TDH, conforme verificado por Oliveira (1997), e as relações AI:AP e AVT:AT estiveram sempre abaixo dos valores máximos apresentados pelo autor, para o primeiro e segundo reatores.

Os resultados obtidos neste estudo concordam com as indicações de RIPLEY et al. (1986), demonstrado na estabilidade da operação do sistema durante os ensaios do experimento.

Na Tabela 4.12 estão apresentados os valores médios de ácidos voláteis: acético, propiônico, isobutírico, butírico, isovalérico, valérico e capróico e seus coeficientes de variação (CV), obtidos durante a operação do sistema em dois estágios nos ensaios 1,2 e 3 do experimento.

Para TDH de 62 h e 31 h, no afluente, observou-se valores médios dos ácidos acético, propiônico e butírico de 685 a 722 mg.L $\mathrm{L}^{-1}, 197$ a $236 \mathrm{mg} . \mathrm{L}^{-1}$ e 204 a 234 mg.L $\mathrm{L}^{-1}$ com coeficiente de variação (CV) de $9,9 \%$ e $28,5 \%, 7,2 \%$ e $18,9 \%$ e $26,9 \%$ e $40,4 \%$, respectivamente. Isto pode ser atribuído à variação da composição da água residuária afluente e ao maior tempo entre a coleta e armazenamento do esterco bruto em geladeira. No ensaio 3, com TDH 16 h, os valores médios dos ácidos butírico e propiônico permaneceram na mesma faixa do ensaio 2, com TDH 31 h, e o ácido acético apresentou valor médio de 519 mg.L ${ }^{-1}$.

No efluente do primeiro reator os valores médios dos ácidos acético e propiônico aumentaram com a diminuição do TDH para $31 \mathrm{~h}$ e aumento da TCOV para 8,75 kg DQO.m ${ }^{-}$ ${ }^{3} . \mathrm{d}^{-1}$, de 62 para $84 \mathrm{mg} . \mathrm{L}^{-1}$ e de 13 para $16 \mathrm{mg} . \mathrm{L}^{-1}$ e sofreram redução na troca de TDH para 16 h, TCOV de 18,65 kg DQO. $\mathrm{m}^{-3} \cdot \mathrm{d}^{-1}$, apresentando valores de 51 e $6 \mathrm{mg} . \mathrm{L}^{-1}$, respectivamente. No segundo reator decresceram de 25 para $21 \mathrm{mg} . \mathrm{L}^{-1}$ e 8 para $3 \mathrm{mg} . \mathrm{L}^{-1}$, respectivamente, e manteve valores semelhantes ao ensaio 2 na troca de TDH para $16 \mathrm{~h}$, ensaio 3 . Os demais ácidos: butírico, isobutírico, isovalérico, valérico e capróico, no efluente dos reatores, decresceram para valores médios abaixo de $8 \mathrm{mg} . \mathrm{L}^{-1} \mathrm{com}$ a diminuição do TDH e aumento da TCOV, indicando a estabilidade dos reatores por meio do consumo dos ácidos voláteis no sistema. 


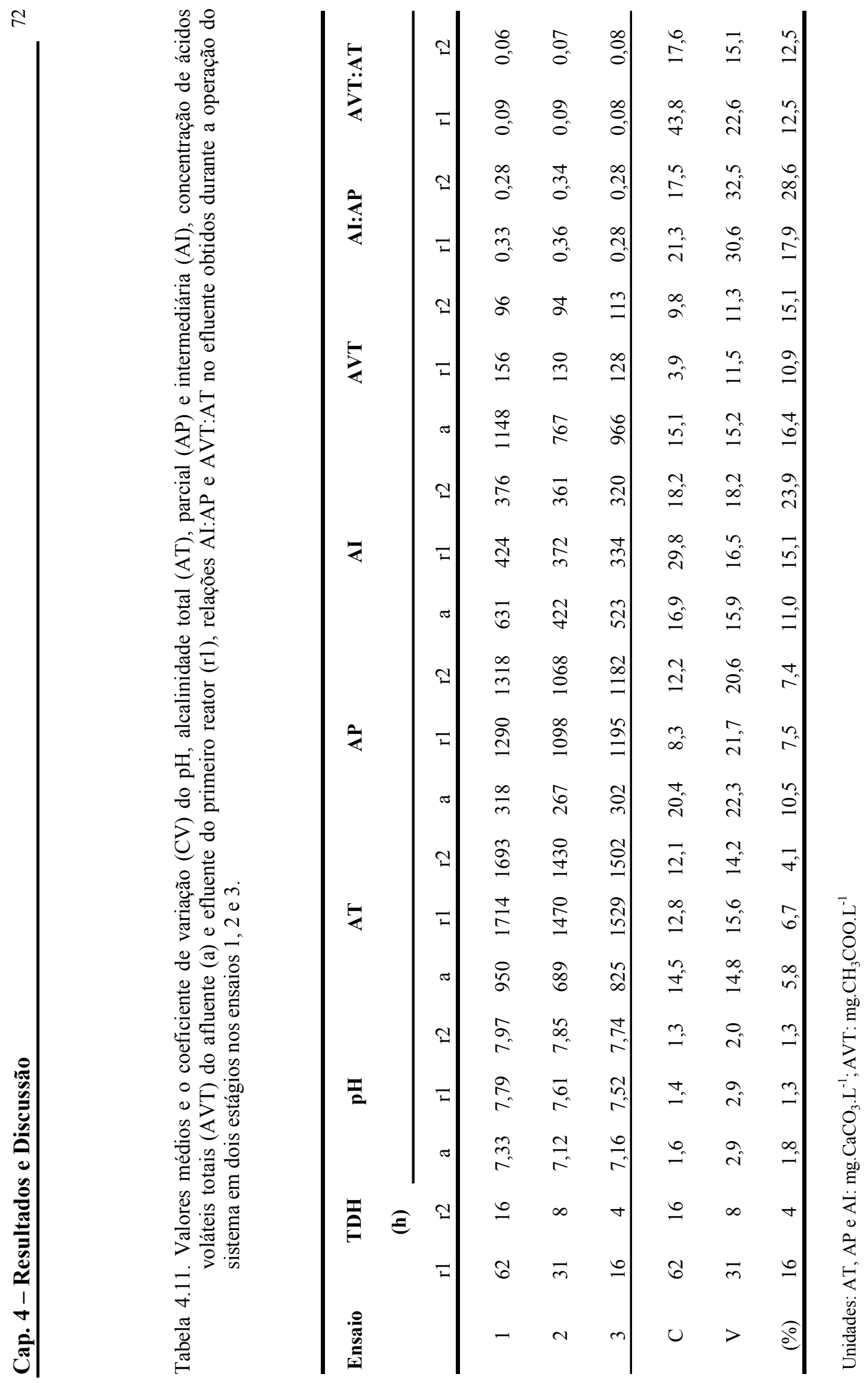




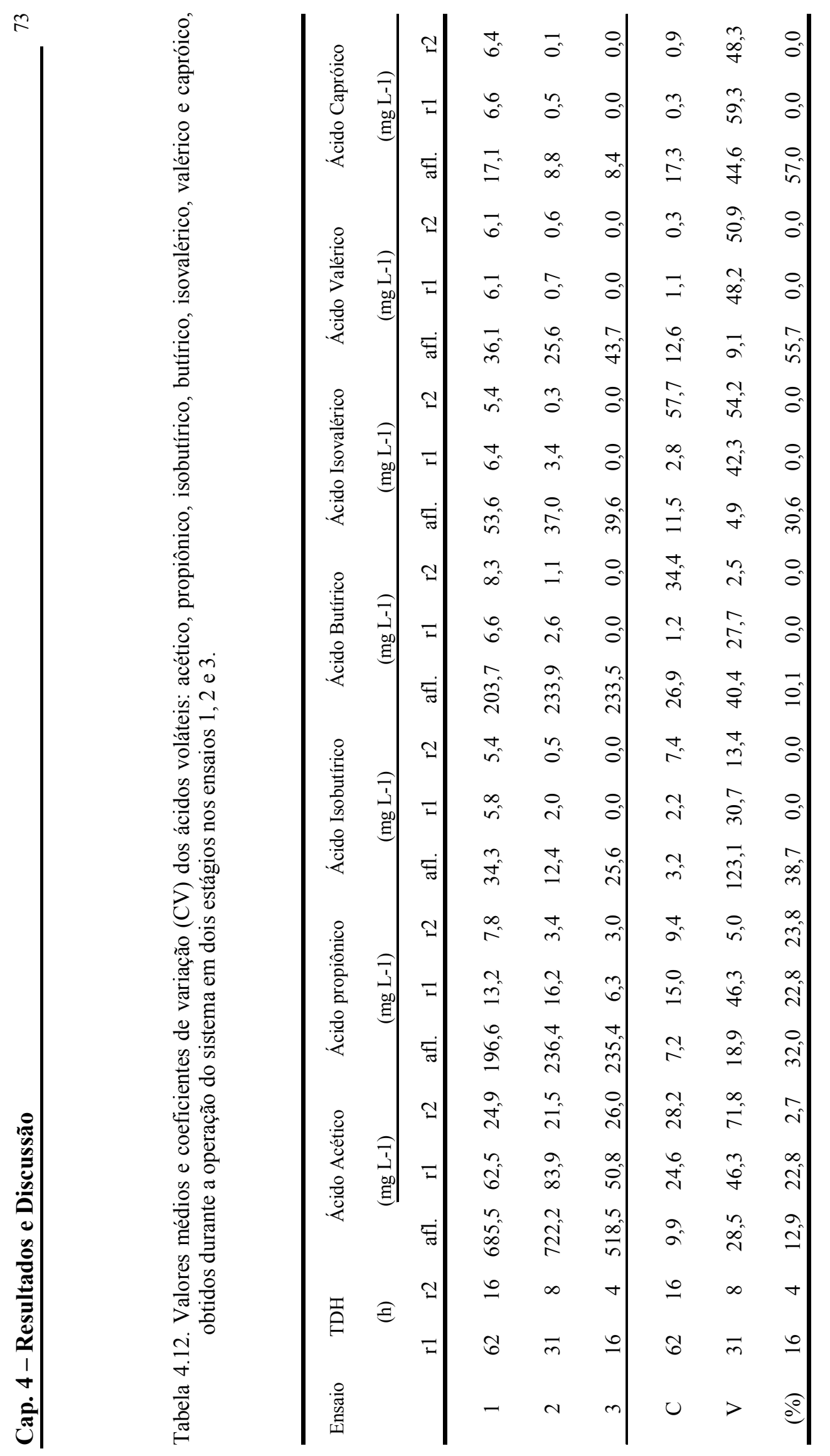




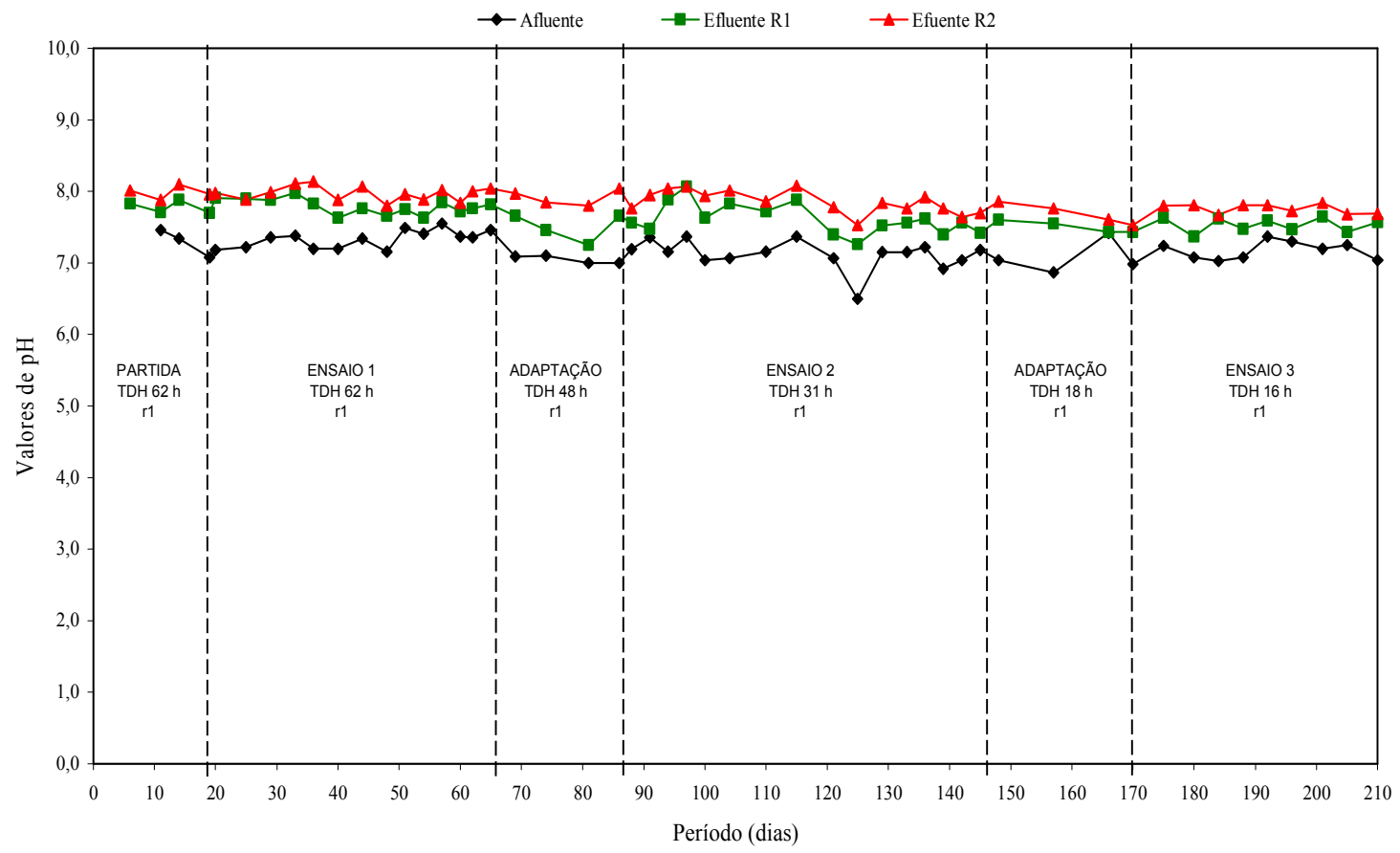

Figura 4.22. Valores de $\mathrm{pH}$ do afluente e efluentes do primeiro e segundo reatores, obtidos nos ensaios 1,2 e 3 .

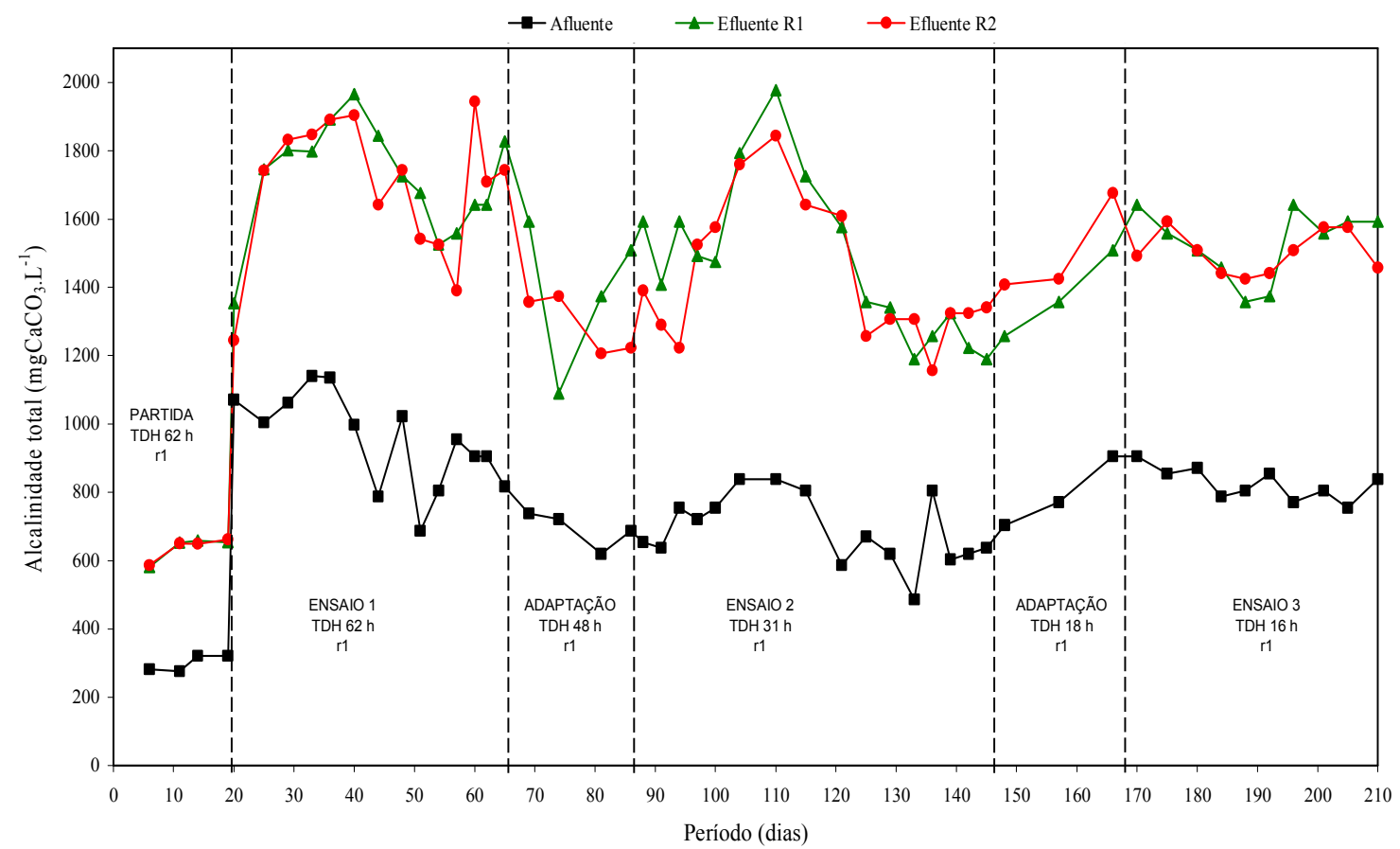

Figura 4.23. Alcalinidade total (AT) do afluente e efluentes do primeiro e segundo reatores, obtidos nos ensaios 1,2 e 3. 


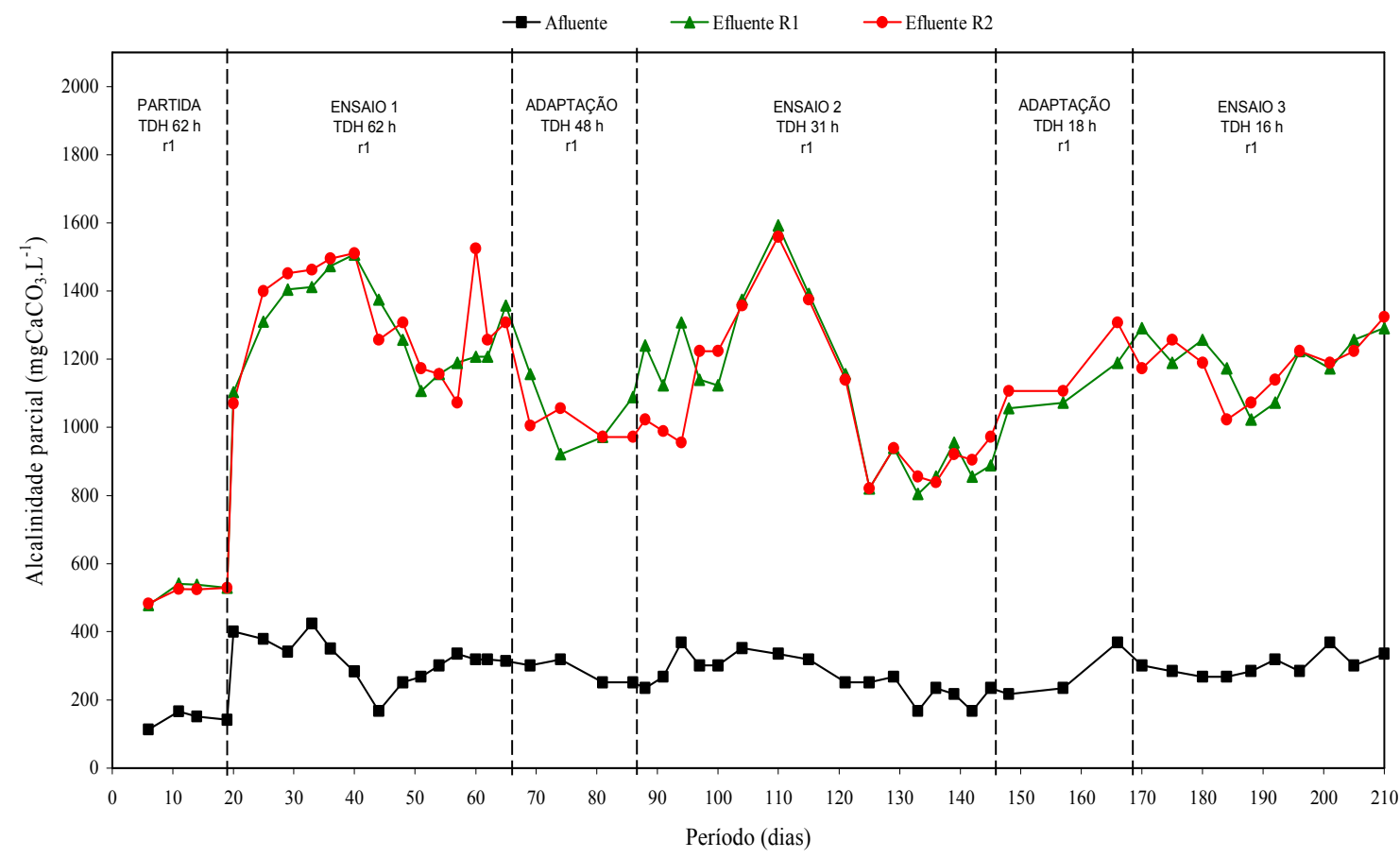

Figura 4.24. Alcalinidade parcial (AP) do afluente e efluentes do primeiro e segundo reatores, obtidos nos ensaios 1,2 e 3.

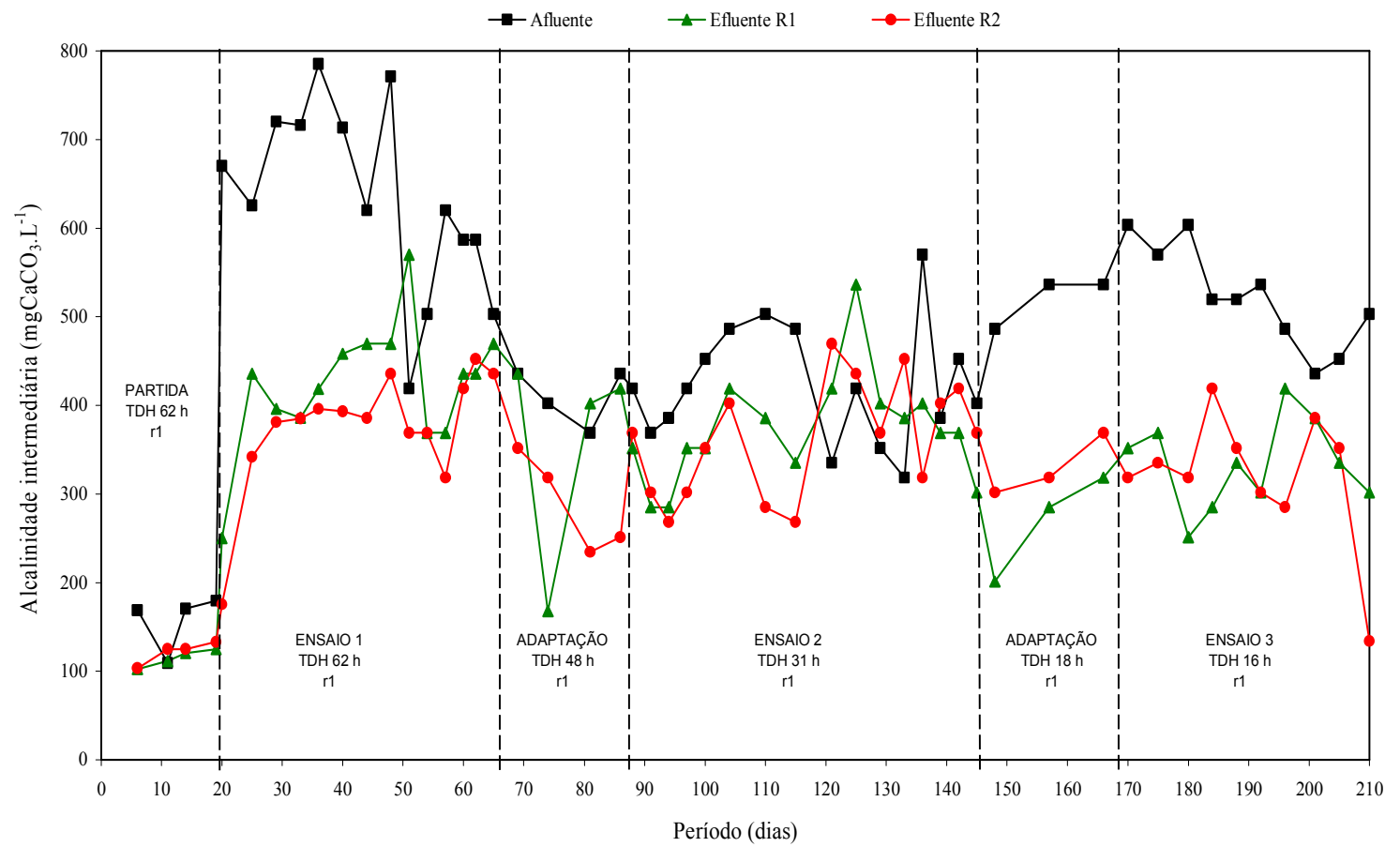

Figura 4.25. Alcalinidade intermediária (AI) do afluente e efluentes do primeiro e segundo reatores, obtidos nos ensaios 1,2 e 3 . 


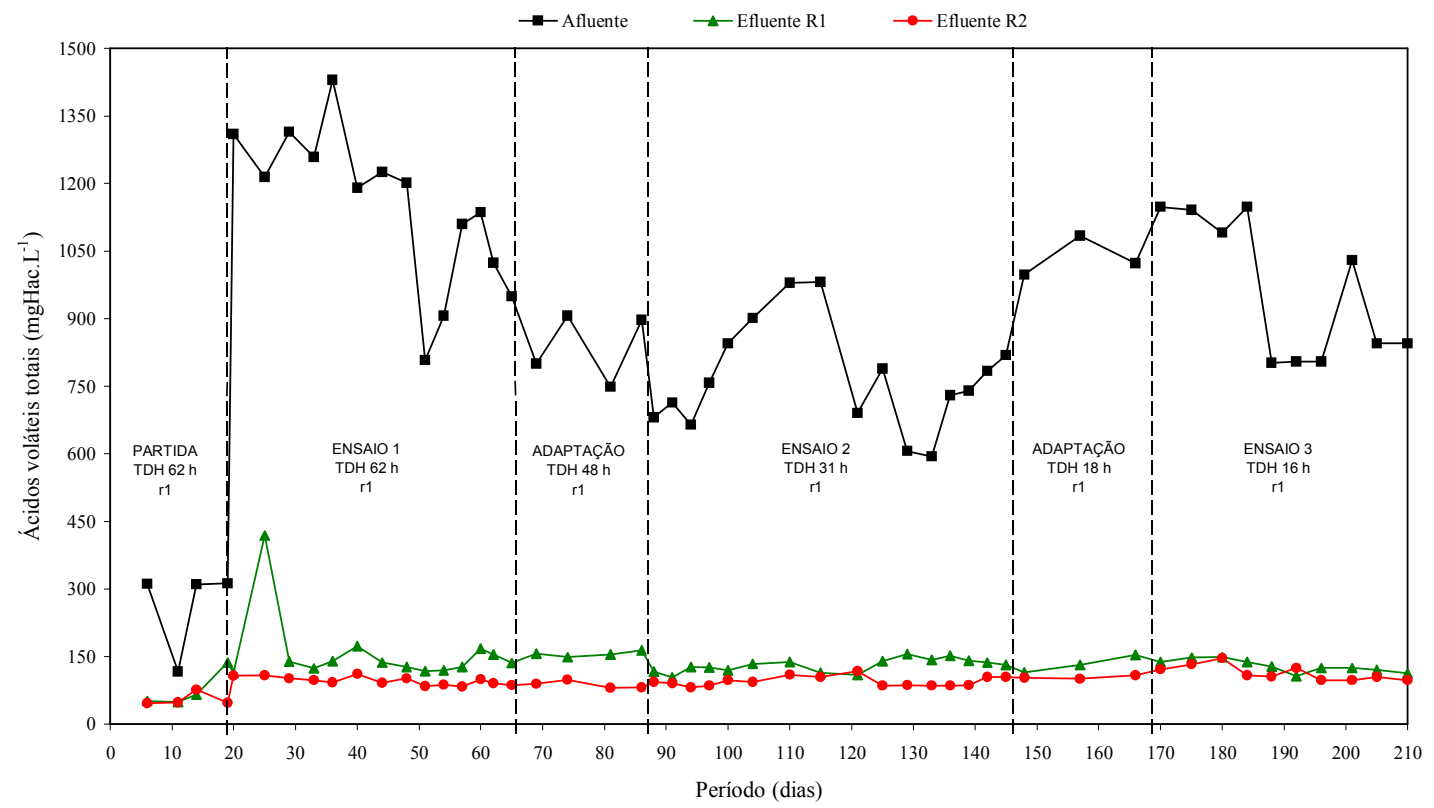

Figura 4.26. Concentrações de ácidos voláteis totais (AVT) obtidas no afluente e efluentes do primeiro e segundo reatores, nos ensaios 1,2 e 3.

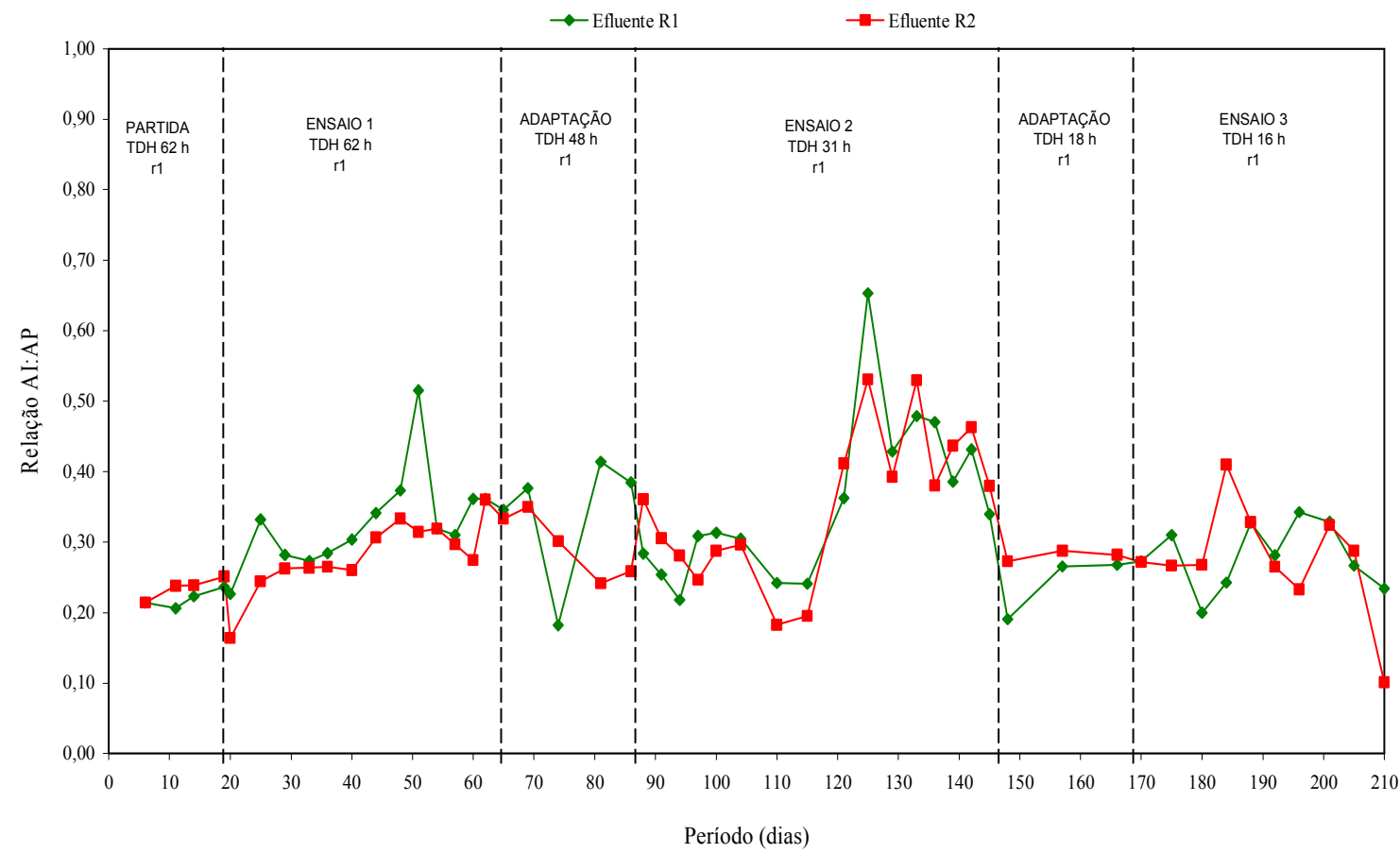

Figura 4.27. Relação AI:AP nos efluentes do primeiro e segundo reatores, obtidos nos ensaios 1, 2 e 3 . 


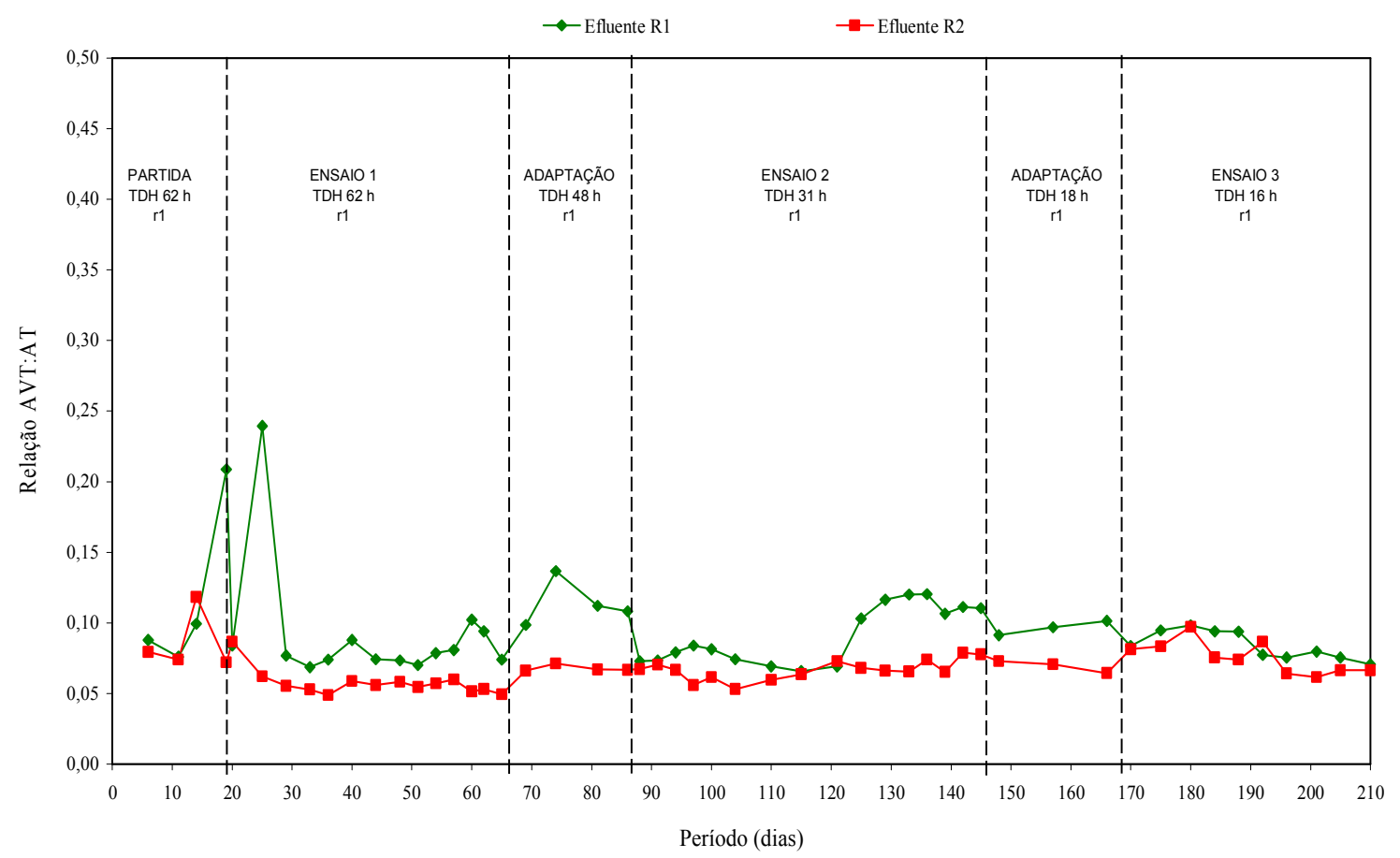

Figura 4.28. Relação AVT:AT nos efluentes do primeiro e segundo reatores, obtidos nos ensaios 1, 2 e 3 .

\subsubsection{Análises microbiológicas}

Nas Tabelas 4.13 e 4.14 estão apresentadas a freqüência dos microrganismos presentes na manta de lodo do primeiro e segundo reatores, no início e final de cada ensaio através da observação por microscopia óptica de contraste de fase e fluorescência. 
Tabela 4.13. Freqüência de microrganismos observada no inóculo, lodo de descarte e na manta de lodo do primeiro reator, nos ensaios 1,2 e 3.

\begin{tabular}{|c|c|c|c|c|c|c|c|c|}
\hline \multirow[t]{2}{*}{ MORFOLOGIA } & \multirow[t]{2}{*}{ Inóculo } & \multirow{2}{*}{$\begin{array}{c}\text { Lodo } \\
\text { Descarte }\end{array}$} & \multicolumn{2}{|c|}{ Ensaio 1 } & \multicolumn{2}{|c|}{ Ensaio 2} & \multicolumn{2}{|c|}{ Ensaio 3} \\
\hline & & & Início & Final & Início & Final & Início & Final \\
\hline \multicolumn{9}{|c|}{ ARQUEAS METANOGÊNICAS } \\
\hline Methanosarcina sp. & ++ & ++ & +++ & ++ & ++ & ++ & ++ & ++ \\
\hline Methanosaeta sp. & ++ & +++ & ++ & +++ & ++ & ++ & +++ & +++ \\
\hline Cistos de sarcinas & - & - & +++ & +++ & ++ & + & - & - \\
\hline Bacilos fluorescentes & ++ & ++ & ++ & ++ & + & ++++ & +++ & ++++ \\
\hline \multicolumn{9}{|l|}{ BACTÉRIAS } \\
\hline Bacilos curvos 1 & ++ & ++ & ++ & ++ & + & ++ & ++ & ++ \\
\hline Bacilos curvos 2 & ++ & ++ & ++ & + & + & +++ & ++ & ++ \\
\hline Bacilos delgados & ++ & ++ & ++ & ++ & ++ & ++ & +++ & ++++ \\
\hline Bacilos ovalados & +++ & +++ & +++ & +++ & +++ & ++ & +++ & +++ \\
\hline Bacilos & ++ & ++ & ++ & ++ & ++ & ++ & +++ & +++ \\
\hline Cocos & +++ & +++ & ++++ & ++++ & +++ & ++++ & +++ & ++++ \\
\hline Cocos em cadeia & ++ & +++ & +++ & ++ & +++ & +++ & +++ & +++ \\
\hline Filamentos & ++ & ++ & ++ & ++ & ++ & ++ & ++ & ++ \\
\hline Filamento com bainha & +++ & ++++ & ++++ & ++++ & ++++ & ++++ & ++++ & ++++ \\
\hline \multicolumn{9}{|l|}{ EUCARIA } \\
\hline Protozoários & ++ & ++ & +++ & ++ & ++ & +++ & +++ & ++ \\
\hline Amebas & - & - & - & - & - & +++ & ++ & + \\
\hline
\end{tabular}


Tabela 4.14. Freqüência de microrganismos observada no inóculo, lodo de descarte e na manta de lodo do segundo reator, nos ensaios 1, 2 e 3 .

\begin{tabular}{|c|c|c|c|c|c|c|c|c|}
\hline \multirow[t]{2}{*}{ MORFOLOGIA } & \multirow[t]{2}{*}{ Inóculo } & \multirow{2}{*}{$\begin{array}{c}\text { Lodo } \\
\text { Descarte } \\
\end{array}$} & \multicolumn{2}{|c|}{ Ensaio 1} & \multicolumn{2}{|c|}{ Ensaio 2} & \multicolumn{2}{|c|}{ Ensaio 3} \\
\hline & & & Início & Final & Início & Final & Início & Final \\
\hline \multicolumn{9}{|c|}{ ARQUEAS METANOGÊNICAS } \\
\hline Methanosarcina sp. & ++ & ++ & +++ & ++ & ++ & ++ & +++ & ++ \\
\hline Methanosaeta sp. & ++ & ++ & ++ & +++ & ++ & +++ & +++ & +++ \\
\hline Cistos de sarcinas & - & - & ++ & + & + & + & - & - \\
\hline Bacilos fluorescentes & ++ & ++ & + & +++ & + & ++++ & +++ & ++++ \\
\hline \multicolumn{9}{|l|}{ BACTÉRIAS } \\
\hline Bacilos curvos 1 & ++ & ++ & ++ & ++ & ++ & +++ & ++ & ++++ \\
\hline Bacilos curvos 2 & ++ & ++ & ++ & ++ & ++ & +++ & ++ & +++ \\
\hline Bacilos delgados & + & +++ & ++ & ++ & ++ & ++ & +++ & +++ \\
\hline Bacilos ovalados & +++ & +++ & ++ & +++ & +++ & +++ & +++ & +++ \\
\hline Bacilos & ++ & ++ & ++ & +++ & +++ & +++ & +++ & +++ \\
\hline $\operatorname{Cocos}$ & +++ & +++ & ++ & +++ & ++++ & ++++ & ++ & +++ \\
\hline Cocos em cadeia & - & ++ & + & ++ & +++ & +++ & ++ & ++ \\
\hline Filamentos & ++ & +++ & ++ & ++ & ++ & ++ & ++ & ++ \\
\hline Filamento com bainha & +++ & ++++ & ++++ & ++++ & ++++ & ++++ & ++++ & ++++ \\
\hline \multicolumn{9}{|l|}{ EUCARIA } \\
\hline Protozoários & ++ & ++ & +++ & +++ & ++ & +++ & +++ & +++ \\
\hline Amebas & - & - & - & - & - & +++ & +++ & +++ \\
\hline
\end{tabular}

No inóculo verificou-se diferentes morfologias microbianas. Células associadas a Methanosaeta, bacilos livres e cocos não fluorescentes foram observadas com maior freqüência que células semelhantes a Methanosarcina. Filamentos longos com bainha foram predominantes.

No ensaio 1 (Figura 4.29), TCOV de 4,55 $\mathrm{kg} \mathrm{DQO}$ total. $\mathrm{m}^{3} \cdot \mathrm{d}^{-1}$, no primeiro reator, as morfologias observadas na manta de lodo do primeiro reator foram praticamente semelhantes no início e final do ensaio. Houve predominância de cocos não fluorescentes, Methanosaeta e filamentos longos com bainha.

No ensaio 2 (Figura 4.30), com diminuição do TDH e conseqüente aumento da TCOV para $8,75 \mathrm{~kg} \mathrm{DQO}$ total. $\mathrm{m}^{3} \cdot \mathrm{d}^{-1}$, no primeiro reator, as morfologias associadas à Methanosarcina 
foram observadas com pouca freqüência. As células semelhantes a Methanosaeta, bacilos não fluorescentes e fluorescentes apresentaram maior freqüência nas condições impostas neste ensaio. Cocos e filamentos longos com bainha continuaram predominantes. Foram observados também protozoários e amebas.

No ensaio 3 (Figura 4.31), com TCOV de 18,65 $\mathrm{kg} \mathrm{DQO}$ total $\cdot \mathrm{m}^{-3} \cdot \mathrm{d}^{-1}$, no primeiro reator, observou-se aumento da freqüência de quase todas as morfologias, principalmente bacilos delgados, bacilos fluorescentes, cocos e filamentos longos com bainha. Outras morfologias observadas nos ensaios anteriores também estiveram presentes, porém em menor freqüência.

As morfologias observadas nas amostras de lodo do segundo reator (Figuras 4.32, 4.33 e 4.34) foram semelhantes às observadas no primeiro reator. Verificou-se que houve presença de vários tipos morfológicos e com predominância das mesmas morfologias em ambos os reatores (Tabelas 4.12 e 4.13). Entretanto no ensaio 3, com TDH de $16 \mathrm{~h}$ no primeiro reator e $4 \mathrm{~h}$ no segundo reator, observou-se que houve seleção de alguns grupos microbianos tais como bacilos com extremidades retas e com extremidades arredondadas, bacilos curvos e bacilos fluorescentes.

Amostras do lodo de descarte, da região superior da manta do primeiro e segundo reatores, também foram coletadas para exames microscópicos. Constatou-se a presença de todas as morfologias observadas nas amostras da manta de lodo dos reatores, porém em menor freqüência.

Na Figura 4.35 estão apresentadas as morfologias semelhantes a filamentos longos com bainha, protozoários e amebas, presentes nas amostras da manta de lodo do primeiro e segundo reatores nos três ensaios. 


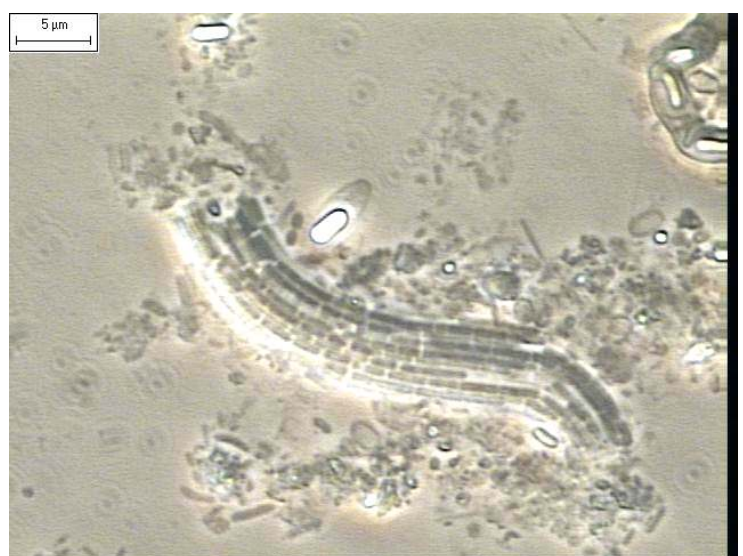

a)

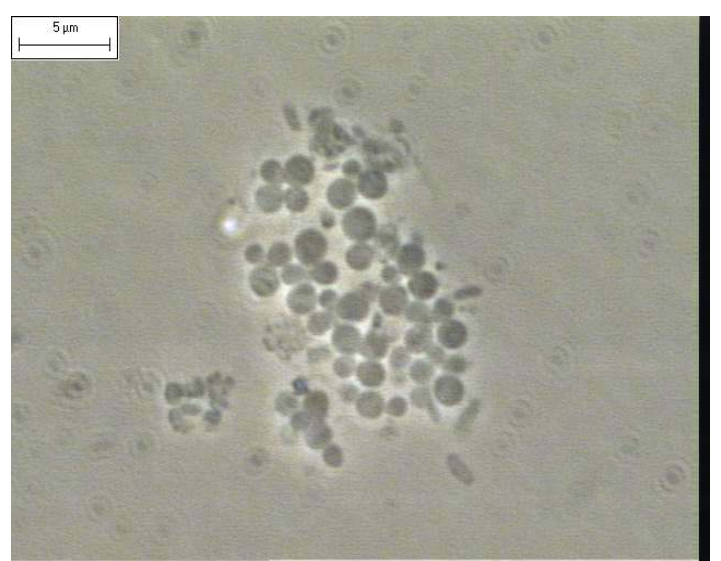

b)

Figura 4.29. Morfologias observadas sob microscopia óptica de contraste de fase da manta de lodo do primeiro reator no ensaio 1: (a) bacilos retos em forma de feixe semelhantes à Methanosaeta e (b) cocos.

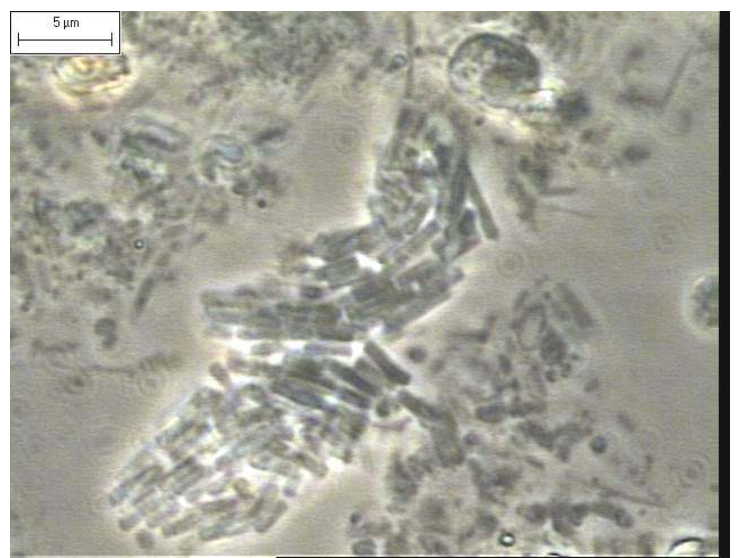

a)

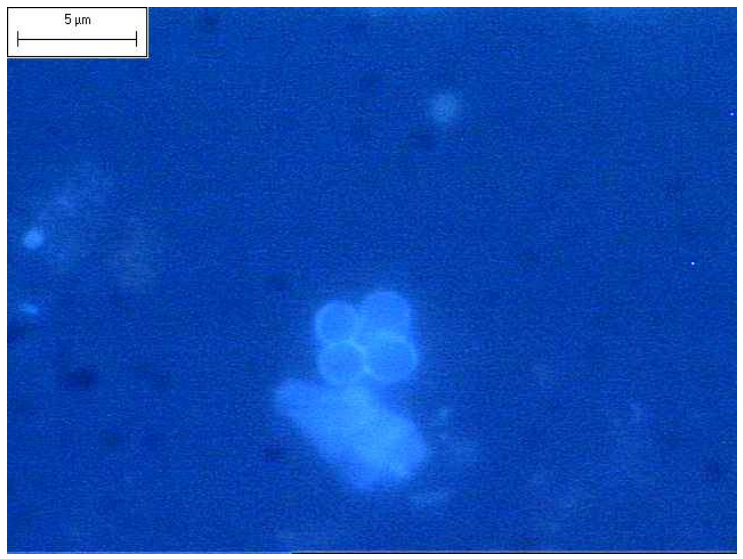

c)

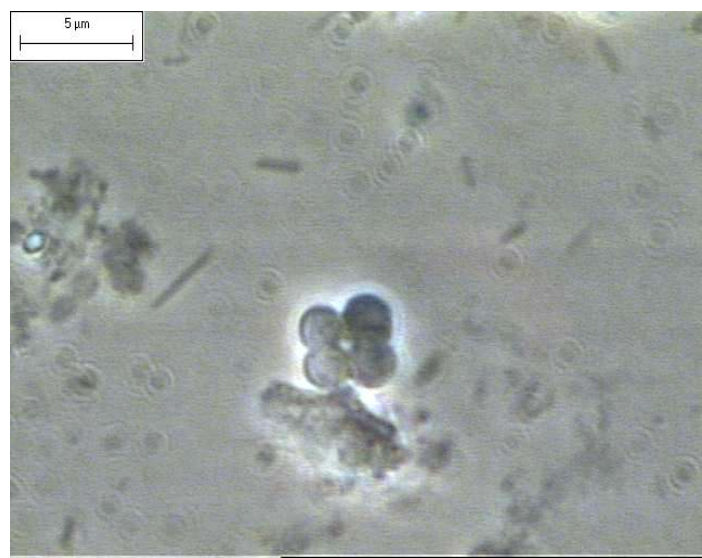

b)

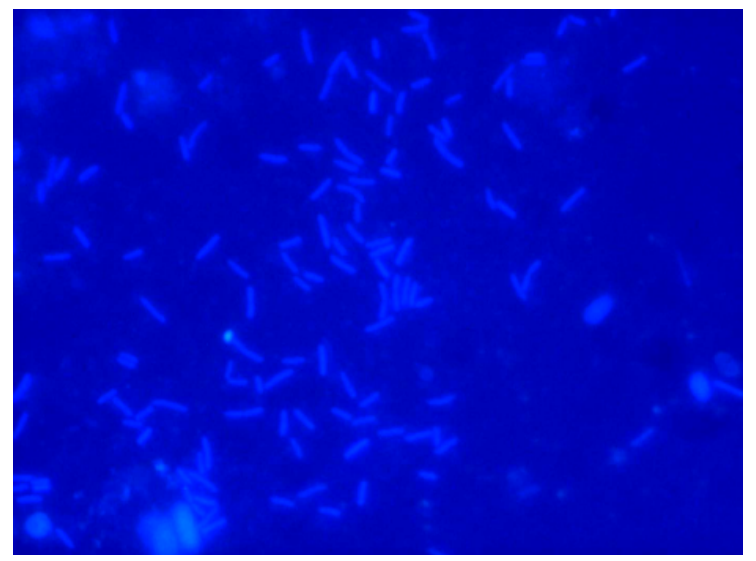

d)

Figura 4.30. Morfologias observadas sob microscopia óptica de contraste de fase e fluorescência da manta de lodo do primeiro reator no ensaio 2: (a) bacilos retos semelhantes a Methanosaeta, (b) cocos em tétrade, (c) cocos fluorescentes e (d) bacilos fluorescentes. 


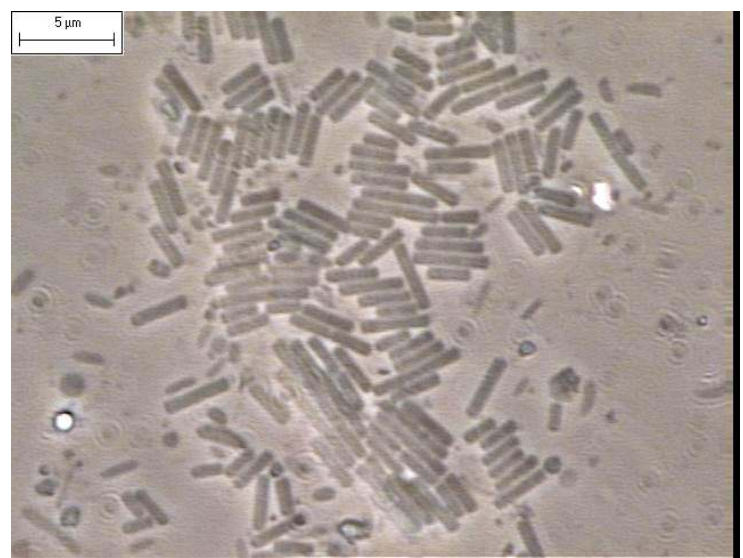

a)

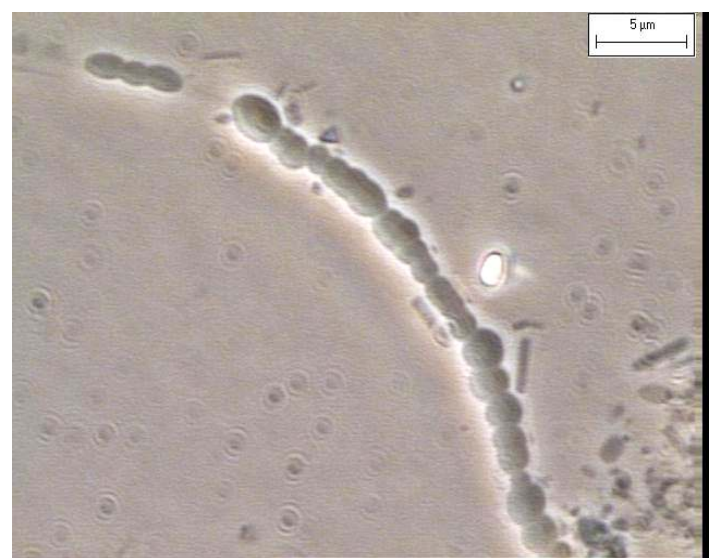

b)

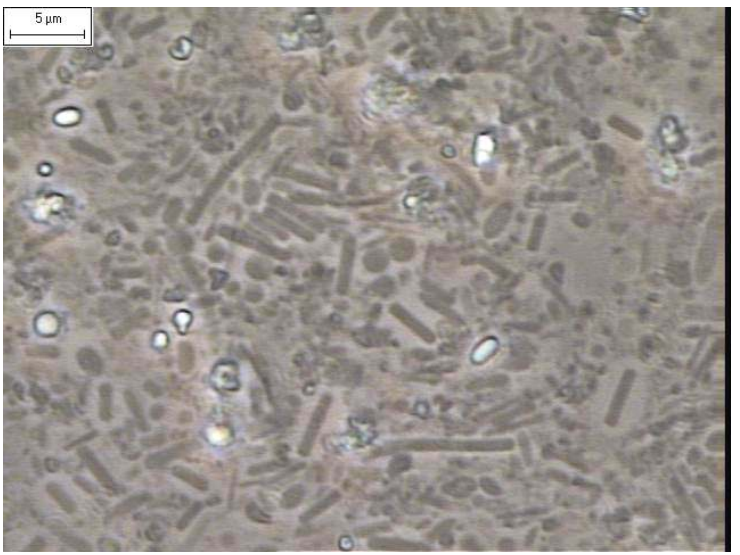

c)

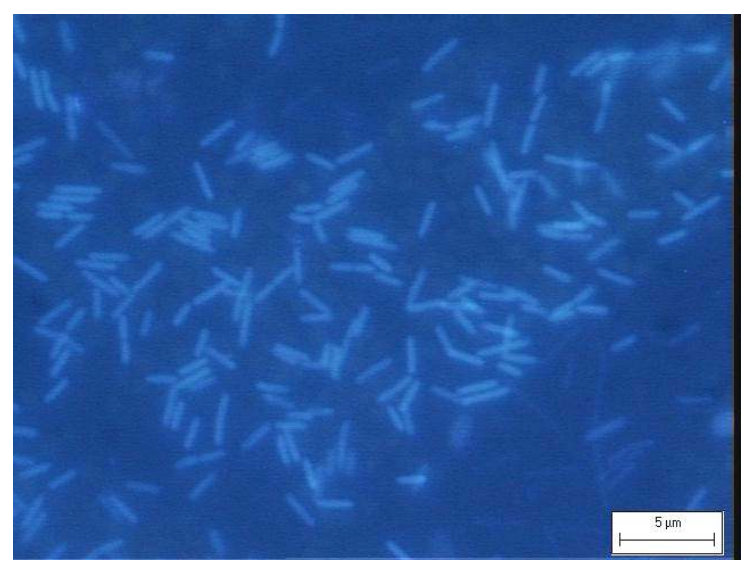

d)

Figura 4.31. Morfologias observadas sob microscopia óptica de contraste de fase e fluorescência da manta de lodo do primeiro reator no ensaio 3: (a) bacilos retos semelhantes a Methanosaeta, (b) cocos em cadeia, (c) bacilos e cocos e (d) bacilos fluorescentes. 


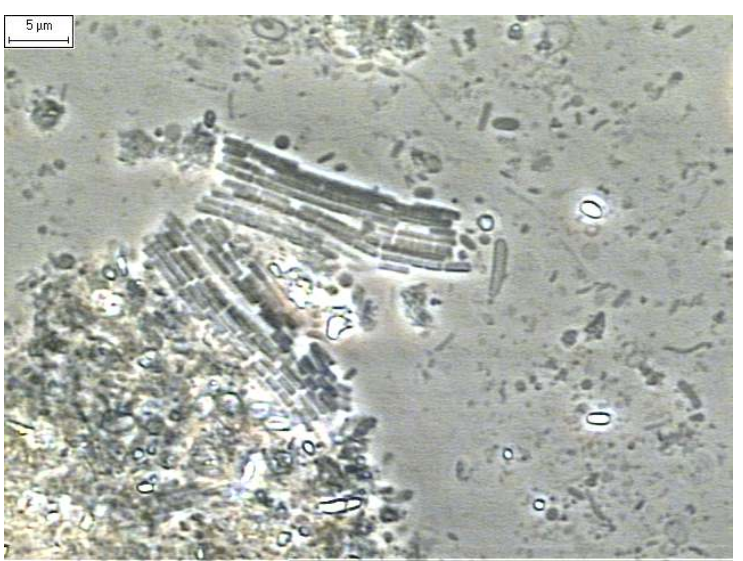

a)

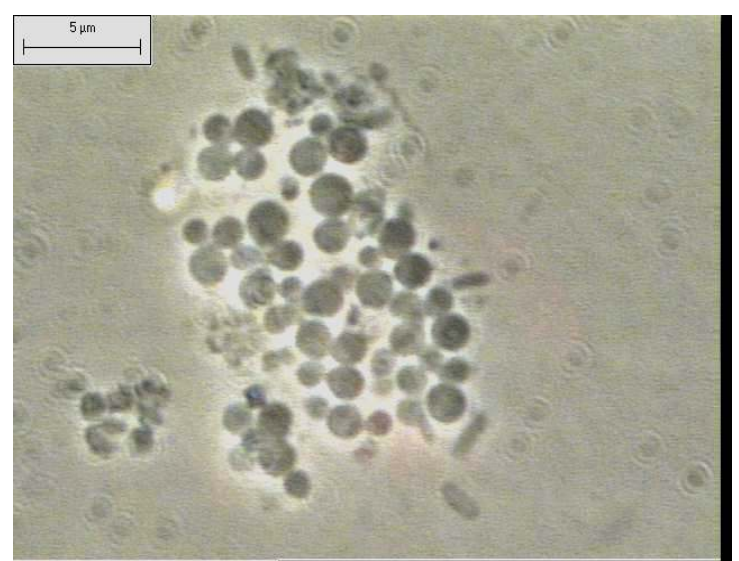

b)

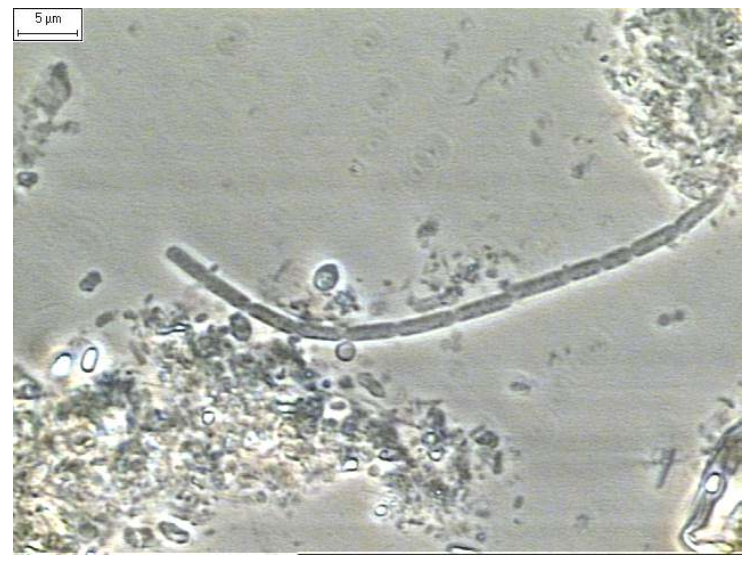

c)

Figura 4.32. Morfologias observadas sob microscopia óptica de contraste de fase da manta de lodo do segundo reator no ensaio 1: (a) bacilos retos semelhantes a Methanosaeta, (b) cocos e (c) filamento septado. 


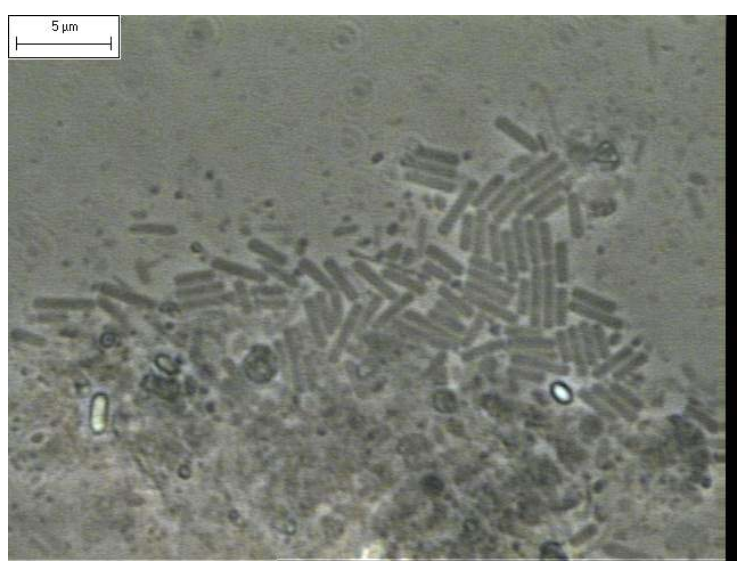

a)

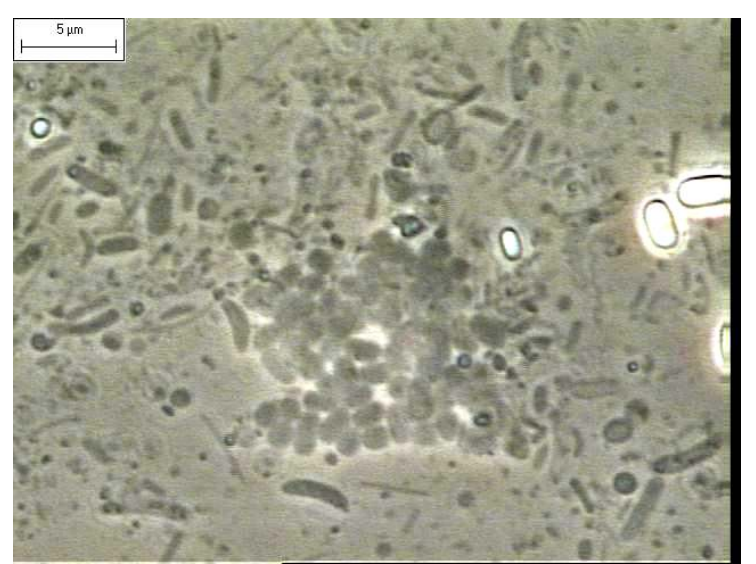

b)

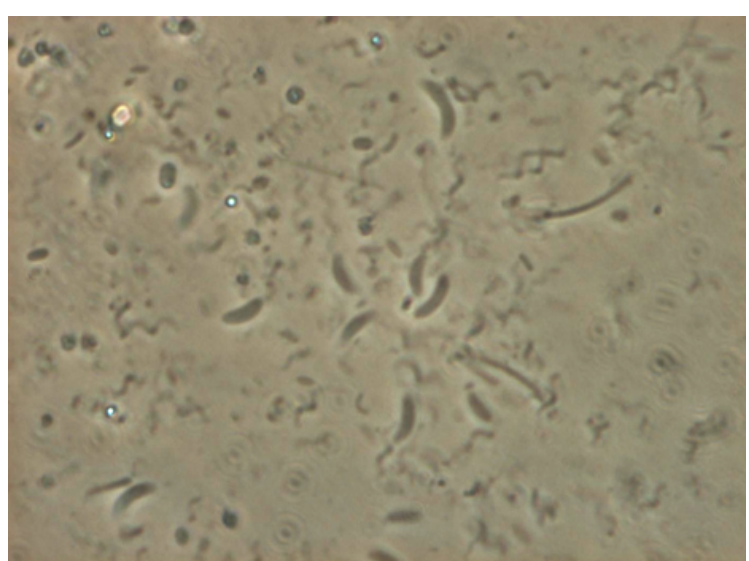

c)

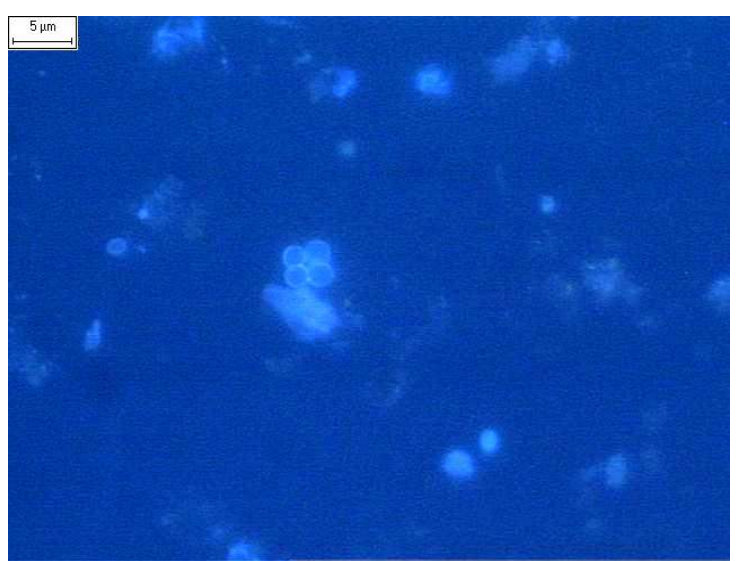

d)

Figura 4.33. Morfologias observadas sob microscopia óptica de contraste de fase e fluorescência da manta de lodo do segundo reator no ensaio 2: (a) bacilos retos semelhantes a Methanosaeta, (b) cocos, (c) bacilos curvos e (d) cocos fluorescentes. 


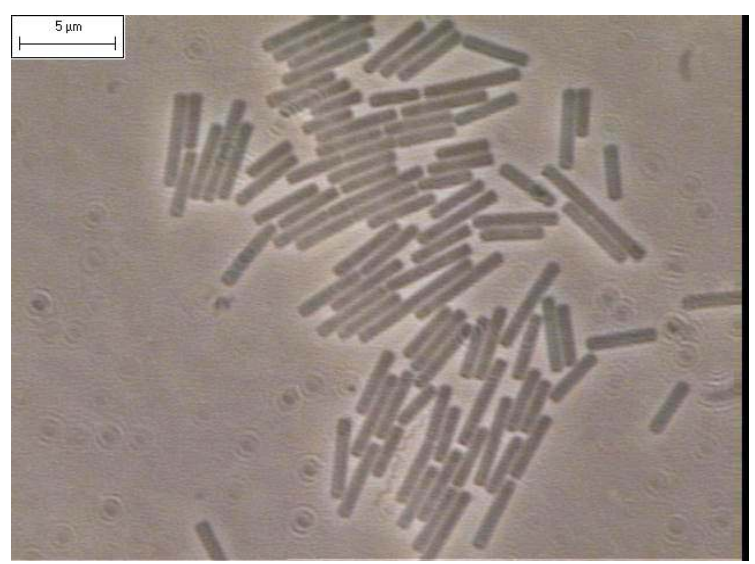

a)

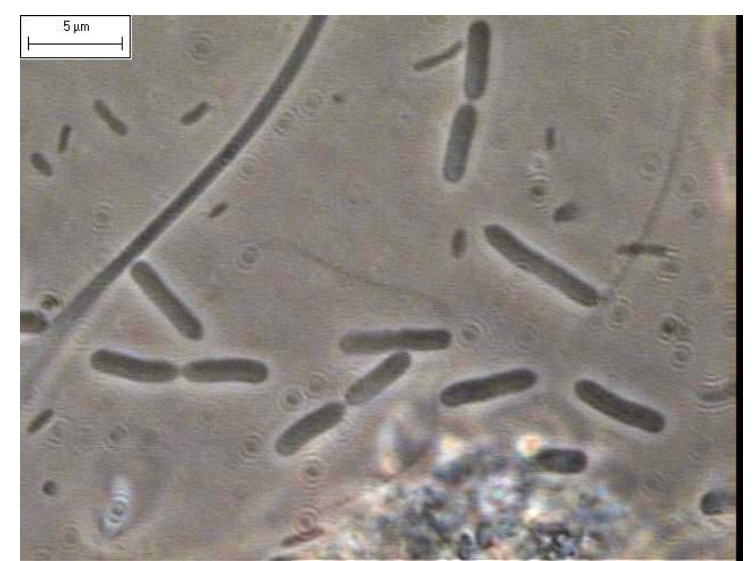

b)

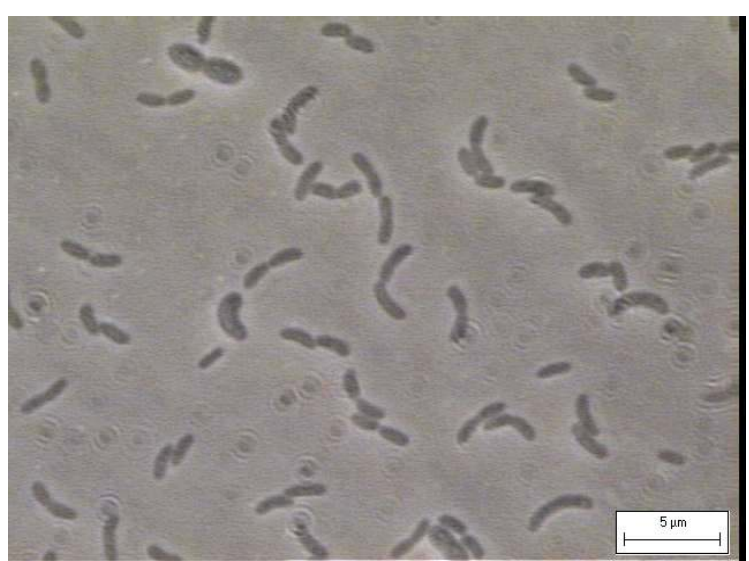

c)

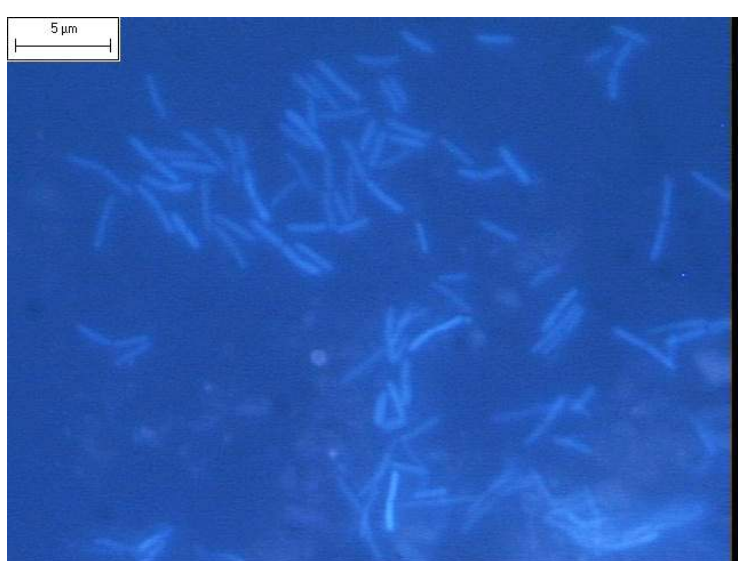

d)

Figura 4.34. Morfologias observadas sob microscopia óptica de contraste de fase e fluorescência da manta de lodo do segundo reator no ensaio 3: (a) bacilos retos semelhantes a Methanosaeta, (b) bacilos com as extremidades arredondadas, (c) bacilos curvos e (d) bacilos fluorescentes. 


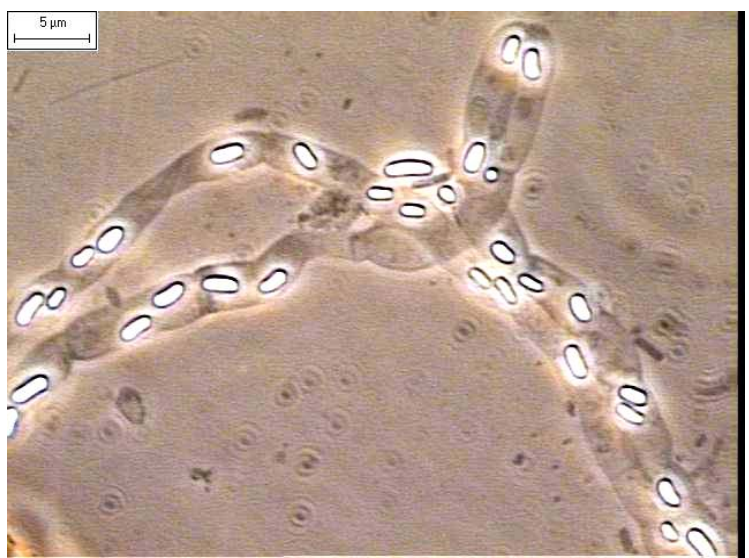

a)

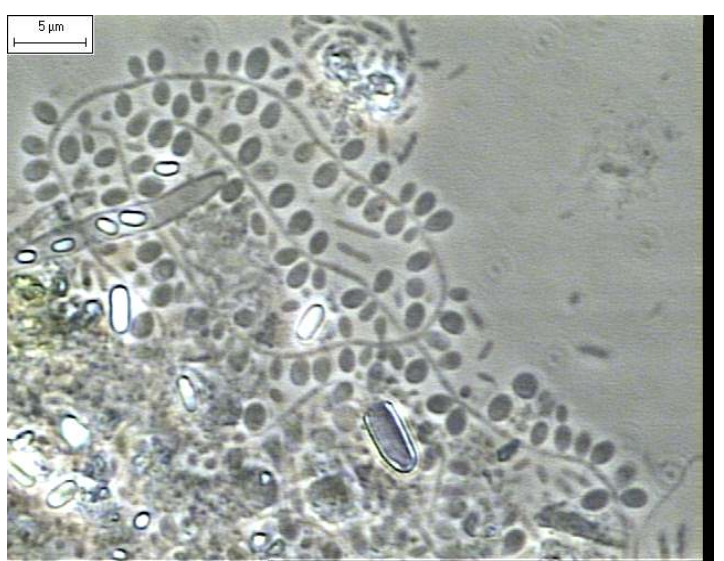

b)

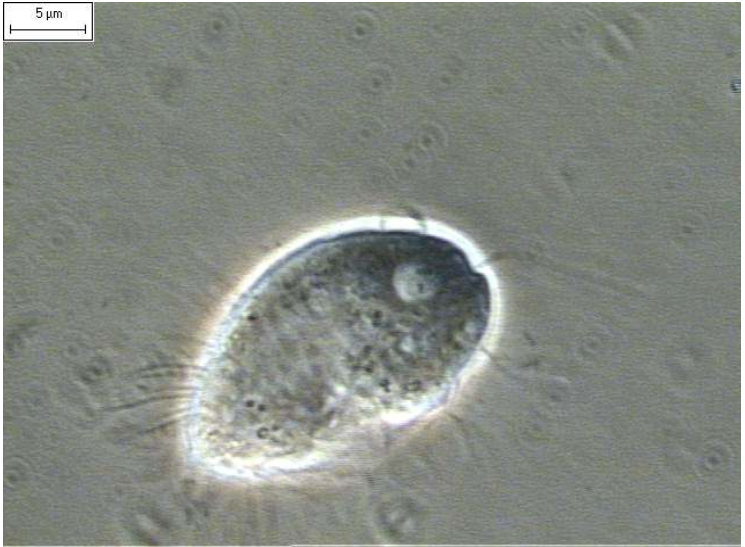

c)

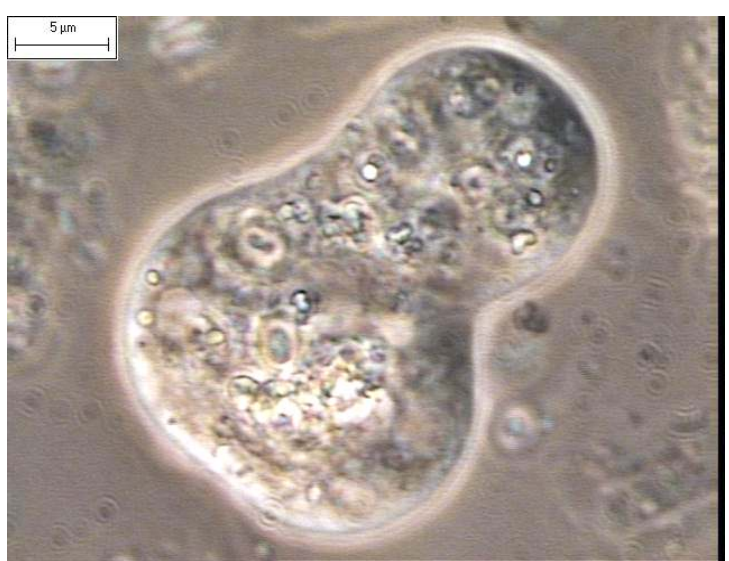

d)

Figura 4.35. Morfologias observadas sob microscopia óptica de contraste de fase da manta de lodo do primeiro e segundo reatores nos ensaios 1, 2 e 3: (a) filamentos longos com bainha, (b) bacilos com extremidade arredondada, (c) protozoários (c) e (d) amebas.

Os grânulos com forma esférica irregular foram cortados transversalmente (Figura 4.36), para observação no $\mathrm{MEV}$, com intuito de verificar a distribuição das populações microbianas a partir da superfície em direção ao interior do grânulo.

Os grânulos foram selecionados das regiões inferiores, intermediárias e superior da manta de lodo do primeiro e segundo reatores e apresentaram tamanhos semelhantes não 
superiores a $1 \mathrm{~mm}$ e de coloração preta, observados visualmente. Não foi verificada a distribuição das morfologias microbianas em três camadas definidas ao longo da parede do grânulo de ambos os reatores. Observou-se morfologias semelhantes nos grânulos do primeiro e segundo reatores.

As observações utilizando o MEV, em grânulos coletados no primeiro e segundo reatores, em determinados pontos da região intermediária e no centro, permitiram verificar maior presença de bacilos com as extremidades retas, semelhantes a Methanosaeta (Figuras 4.37 e 4.38). Cocos e bacilos ovalados (Figuras 4.39, 4.40, 4.41 e 4.42) também foram observados com muita freqüência nestas regiões. Na região externa do grânulo do primeiro e segundo reatores (Figuras 4.43 e 4.44), próximo à superfície, observou-se à presença mais acentuada de cocos e bacilos ovalados e menor freqüência de morfologias associadas a Methanosaeta.

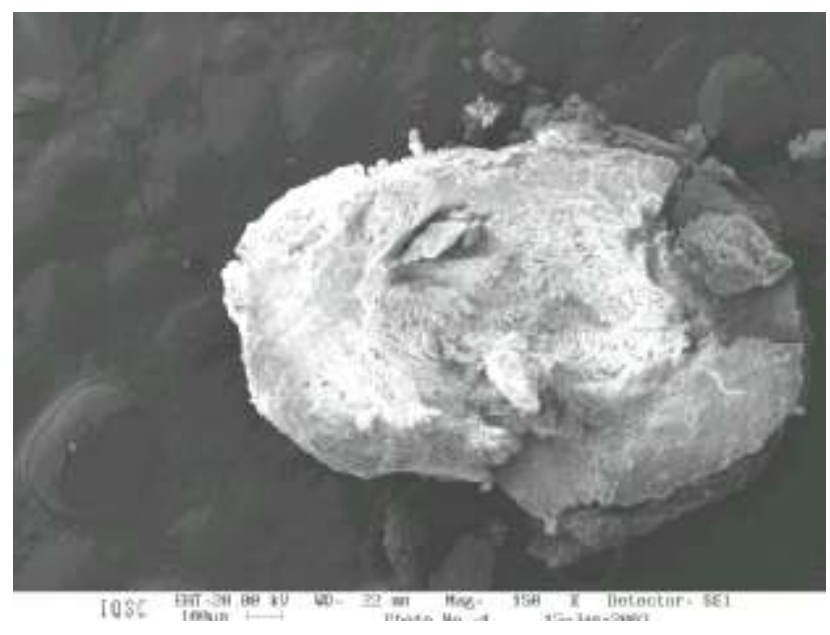

Figura 4.36. Microscopia eletrônica de varredura (MEV) do grânulo, cortado transversalmente, da manta de lodo do primeiro reator no final do experimento. 


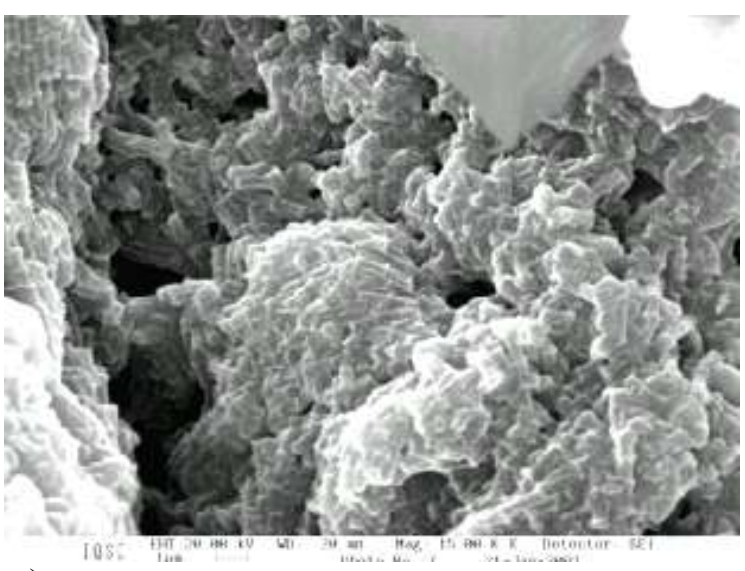

a)

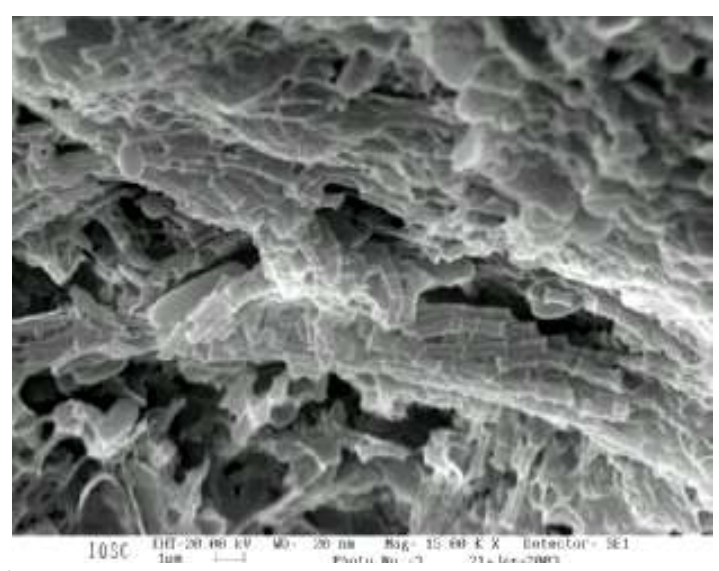

b)

Figura 4.37. Microscopia eletrônica de varredura (MEV) das camadas intermediária (a) e central (b) de grânulos coletados da manta de lodo do primeiro reator, apresentando morfologia semelhante a Methanosaeta.

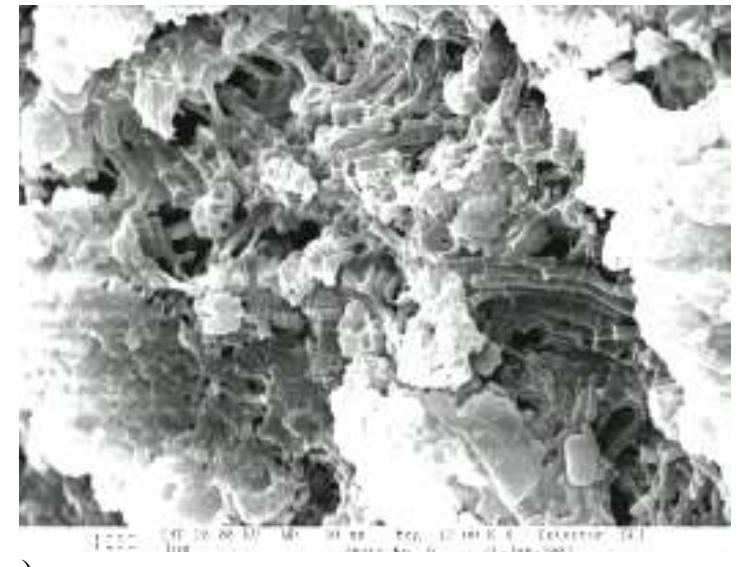

a)

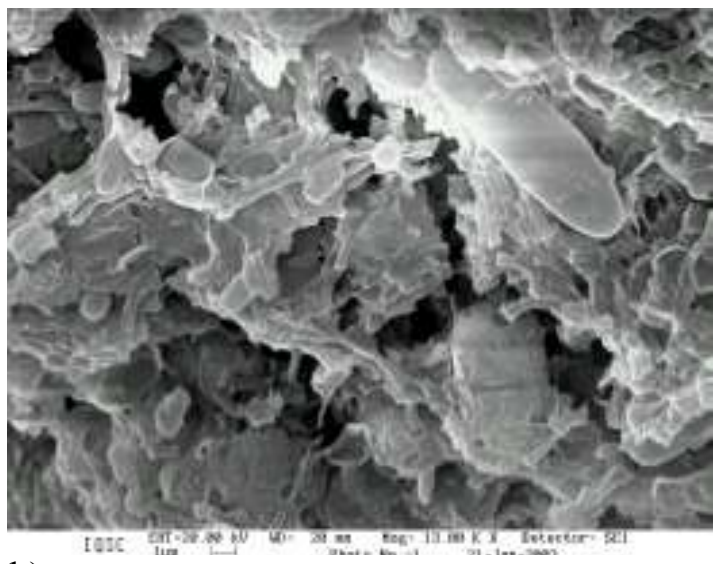

b)

Figura 4.38. Microscopia eletrônica de varredura (MEV) das camadas intermediária (a) e central (b) de grânulos coletados da manta de lodo do segundo reator, apresentando morfologia semelhante a Methanosaeta. 


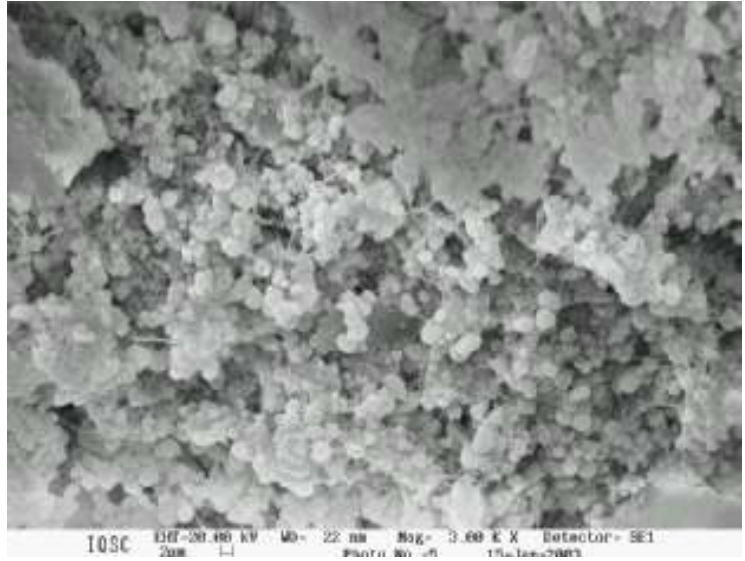

a)

Figura 4.39. Microscopia eletrônica de varredura (MEV) das camadas intermediária (a) e central (b) de grânulos coletados da manta de lodo do primeiro reator, com predomínio de cocos.

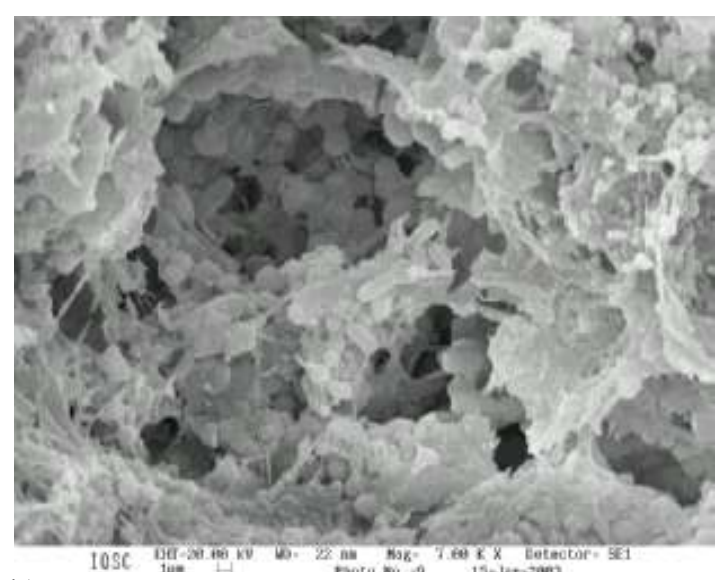

b)

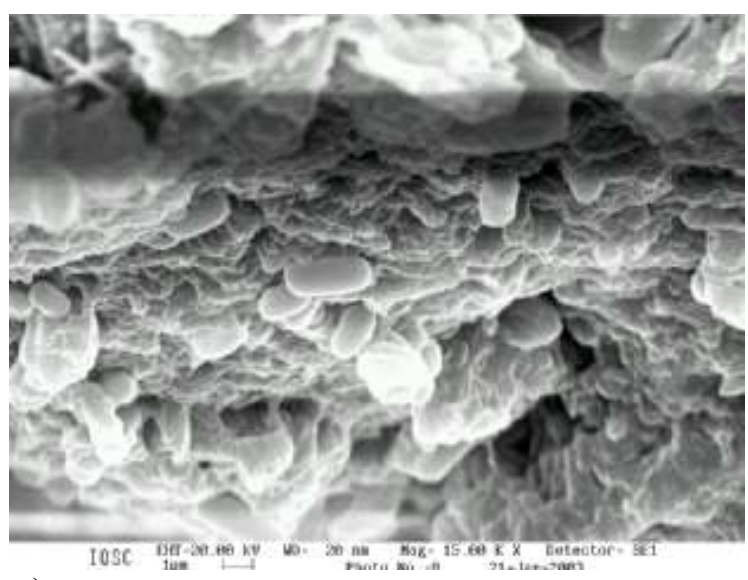

a) 


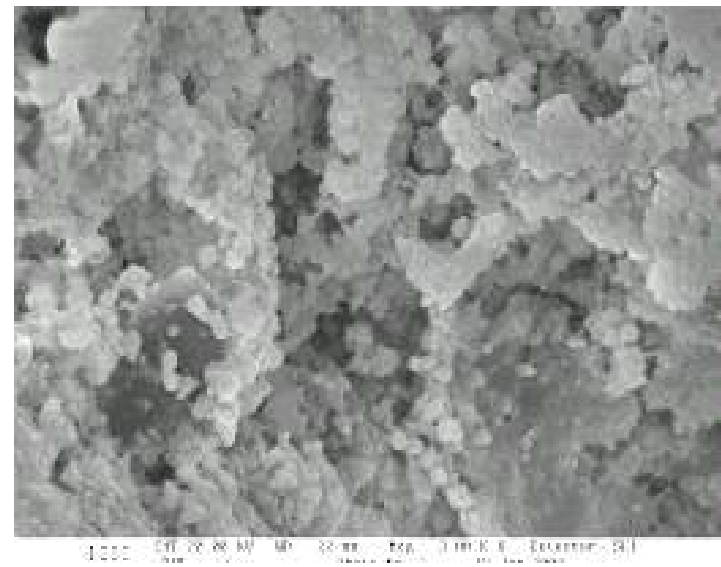

a)

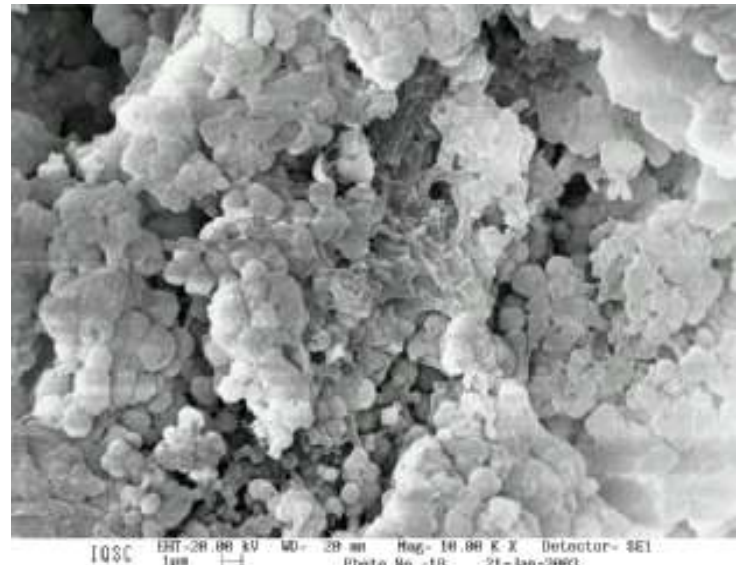

b)

Figura 4.41. Microscopia eletrônica de varredura (MEV) das camadas intermediária (a) e central (b) de grânulos coletados da manta de lodo do segundo reator, apresentando predomínio de cocos.

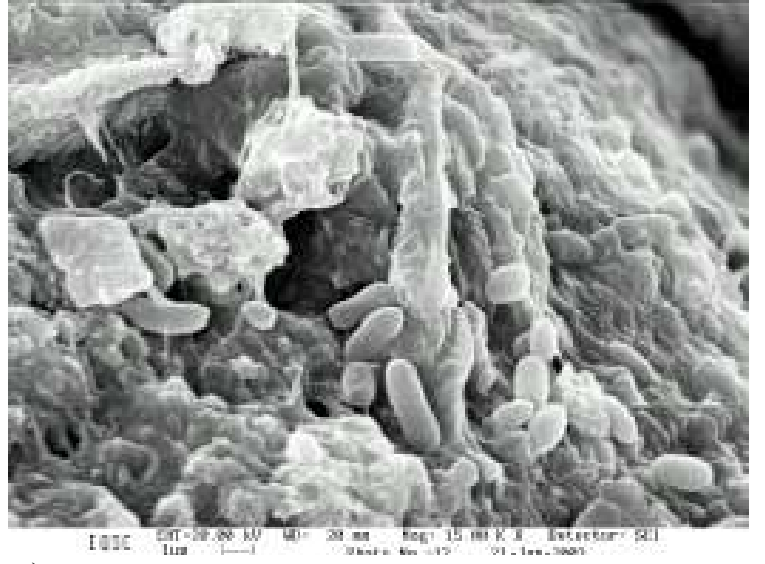

a)

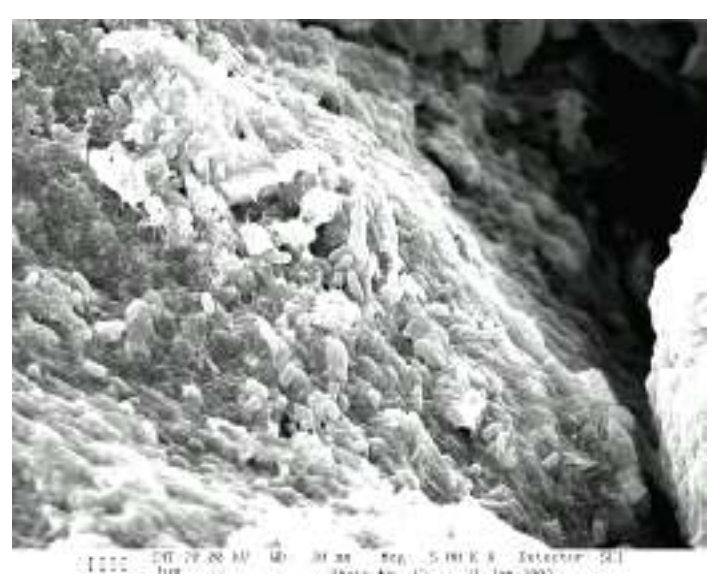

b)

Figura 4.42. Microscopia eletrônica de varredura (MEV) das camadas intermediária (a) e central (b) de grânulos coletados da manta de lodo do segundo reator, apresentando predomínio de bacilos ovalados. 

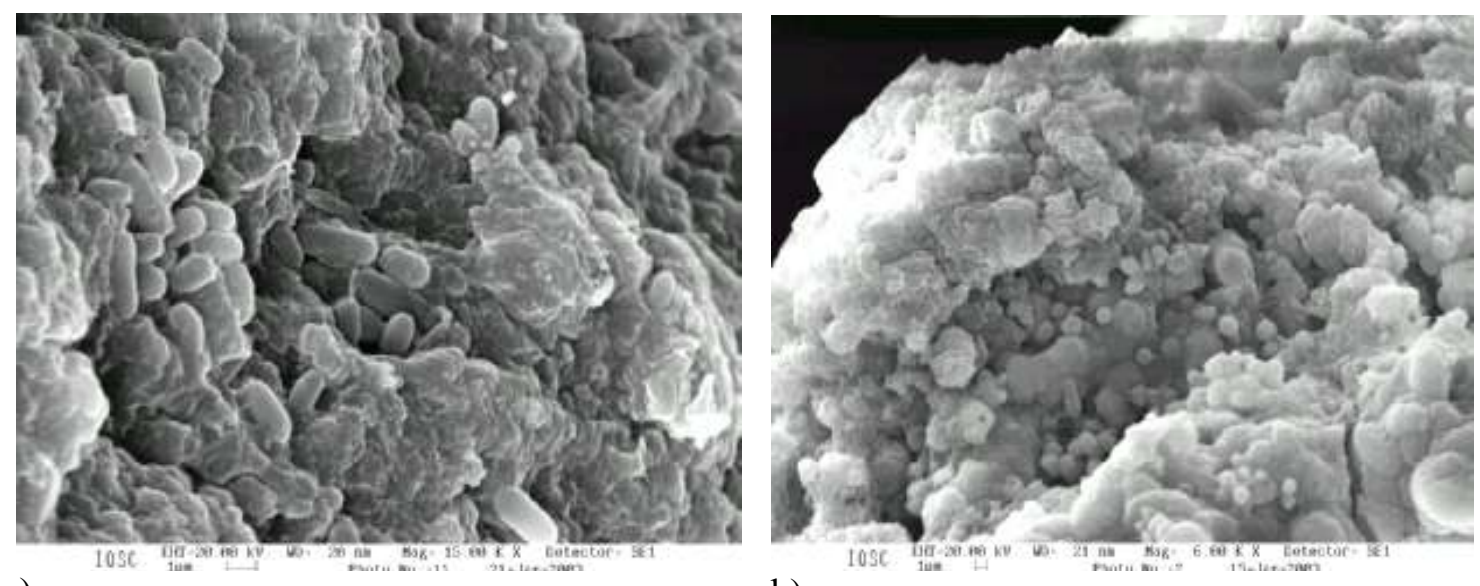

a)

b)

Figura 4.43. Microscopia eletrônica de varredura (MEV) da camada externa de grânulos coletados da manta de lodo do primeiro reator, com bacilos (a) e cocos (b).

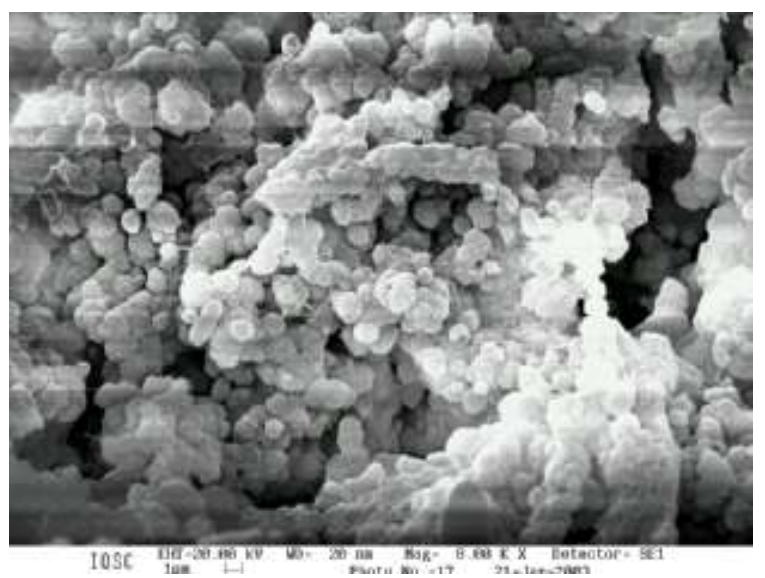

a)

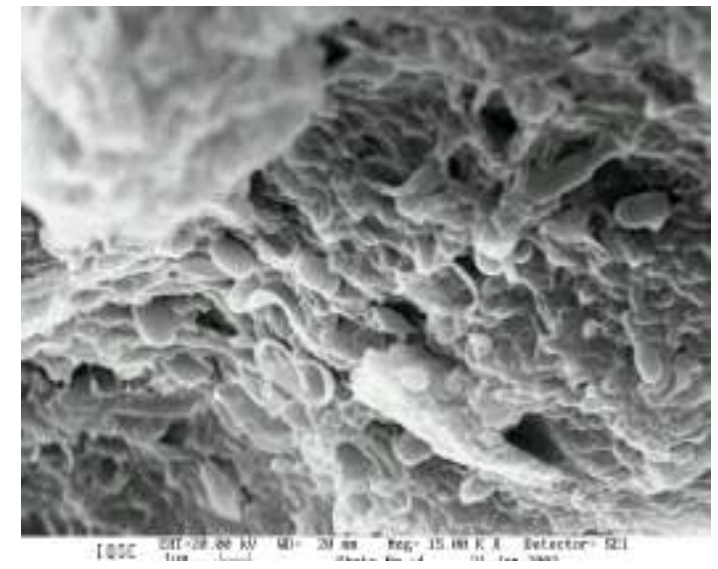

b)

Figura 4.44. Microscopia eletrônica de varredura (MEV) da camada externa de grânulos coletados da manta de lodo do segundo reator, apresentando $\operatorname{cocos}(a)$ e bacilos ovalados (b).

A partir do exame por meio do MEV, verificou-se arranjo disperso das morfologias semelhantes a Methanosaeta, bacilos e cocos por todas as regiões do grânulo. Porém, as células associadas a Methanosaeta foram observadas em pontos isolados nas regiões centrais dos grânulos. 
Comparativamente às observações de Samson et al. (1990) e Hulshoff (1989), supõe-se que as altas concentrações de SST utilizadas neste estudo (em torno de $5000 \mathrm{mg} . \mathrm{L}^{-1}$ ) prejudicaram a formação de grânulos nos reatores durante a operação. Assim, a formação de grânulos pequenos e irregulares na manta dos reatores durante os ensaios do experimento, apresentando arranjo "frouxo" de morfologias, pode estar relacionada com a agitação da manta provocada pela concentração de bolhas de gás e, conseqüentemente, maiores forças de cisalhamento tenham sido impostas, devido à alta concentração de SST no afluente, dificultando a aderência de bactérias acidogênicas à superfície externa dos grânulos.

Segundo Samson et al. (1990) e Hulshoff (1989), composições com elevadas frações de sólidos em suspensão ou materiais refratários e o aumento na velocidade ascensional do líquido e do volume de gás, levam à seleção dos componentes das partículas do lodo e podem prejudicar a formação de grânulos.

Comparando-se ao estudo efetuado por Oliveira (1997), não foi possível observar estrutura em camadas definidas. Os grânulos coletados nas regiões da manta de lodo dos reatores não apresentaram tamanhos diferentes e as morfologias observadas estavam distribuídas de forma dispersa no interior dos grânulos. A presença de arqueas metanogênicas semelhantes a Methanosaeta, observadas em pontos isolados da região central dos grânulos examinados, pode estar associada à manutenção de concentrações de ácidos voláteis totais (AVT) nos reatores, quase sempre superiores a $100 \mathrm{mg} \cdot \mathrm{L}^{-1}$.

Neste trabalho os reatores foram operados com temperatura controlada de 25 a $30^{\circ} \mathrm{C}, \mathrm{o}$ que não deve estar relacionado com a formação de grânulos sem estrutura em camadas definidas. Como mencionado anteriormente, Oliveira (1997) trabalhando com reatores UASB a temperatura controlada de 25 e $30^{\circ} \mathrm{C}$, tratando água residuária de suinocultura com concentrações de SST de 1000 a 2000 mg.L $\mathrm{L}^{-1}$,observou a formação de grânulos com estrutura definida em três camadas. Isto reforça a suposição de ter sido a concentração de SST do afluente (em torno de $5000 \mathrm{mg} . \mathrm{L}^{-1}$ ) o fator prejudicial na formação e distribuição microbiana no grânulo e não a temperatura.

No entanto, segundo Banik et al. (1997), a faixa de temperatura de $25^{\circ} \mathrm{C}$ também pode exercer efeito negativo sobre a composição e distribuição microbiana de grânulos. Os autores compararam o desenvolvimento de grânulos a diferentes temperaturas $\left(5,15\right.$ e $\left.25^{\circ} \mathrm{C}\right)$ em reatores alimentados com resíduo sintético de leite desnatado. Os grânulos crescidos a $25^{\circ} \mathrm{C}$ não exibiram estrutura em camadas. A parte externa apresentou predomínio de cocos, bacilos e filamentos. Os grânulos não apresentaram larga variedade de espécies e eram 
predominantemente compostos por amontoados frouxos de células semelhantes a Methanosaeta, material inorgânico e polímeros extracelulares.

Aparentemente, nos grânulos do primeiro e segundo reatores, não foram observadas com evidência morfologias semelhantes a estreptococos, que pudessem indicar com clareza a sua predominância na hidrólise dos SS presentes na água residuária de suinocultura.

No entanto, Fang e Kwong ${ }^{8}$ (1994 apud OLIVEIRA, 1997), Kwong e Fang ${ }^{9}$ (1996 apud OLIVEIRA, 1997) e Fang ${ }^{10}$ et al. (1995 apud OLIVEIRA, 1997), encontraram na camada externa de grânulos a presença predominante de estreptococos associados a complexos enzimáticos, que efetuam a hidrólise de celulose e seus derivados, aos quais foi atribuída a hidrólise do amido de milho.

Por não ter sido observado orientação espacial das morfologias, de forma estruturada em camadas definidas, e pela maior presença de sólidos finos na manta dos reatores, possivelmente a hidrólise dos SS tenha sido efetuada, predominantemente, por microrganismos em suspensão.

No exame por meio de microscopia óptica de material suspenso e de grânulos macerados do primeiro e segundo reatores, observou-se a presença predominante de filamentos, os quais poderiam estar associados à hidrólise, da mesma forma que os bacilos distribuídos na superfície externa do grânulo.

Hobson e Shaw ${ }^{11}$ (1974 apud OLIVEIRA, 1997) encontraram em resíduos de suínos submetidos à digestão anaeróbia algumas bactérias na forma de bacilos com atividade celulolítica, hemicelulolítica e proteolítica. Porém, de acordo com Oliveira (1997), seria necessário o exame mais detalhado destes e outros microrganismos presentes, como os observados na manta dos reatores, para definir quais são hidrolíticos e em quais das condições (em suspensão ou no grânulo) ocorreu com predominância a hidrólise dos SS do afluente.

Por meio das observações, pôde-se observar a presença de vários tipos morfológicos (Tabelas 4.12 e 4.13), não observados no interior dos grânulos, levando a supor que tenha ocorrido atividade mais intensa de microrganismos na degradação dos compostos orgânicos

\footnotetext{
${ }^{8}$ FANG, H.H.P., KWONG, T.S. (1994). Degradation of starch particulates in a hybrid reactor. Water Science of Technology, v.30, n.4, p. 97-104.

${ }^{9}$ KWONG, T.S., FANG, H.H.P. (1996). Anaerobic degradation of cornstarch in wastewater in two upflow reactors. Journal of Environmental Engineering, v.122, n.1, p. 9-17.

${ }^{10}$ FANG, H.H.P., CHUI, H.K., LI, Y.Y. (1995). Effect of degradation kinects on the microstructure of anaerobic biogranules. Water Science of Technology, v.32, n.8, p. 165-172.

${ }^{11}$ HOBSON, P.N., SHAW, B.G. (1974). The bacterial population of piggery-waste anaerobic digesters. Water Resource, v.8, p. 507-516.
} 
no material em suspensão da manta de lodo, o que não afetou o desempenho dos reatores na remoção de matéria orgânica. 


\section{CONCLUSÕES}

A obtenção, análise e discussão dos resultados dos ensaios do experimento com reatores UASB de bancada, instalados em série (sistema em dois estágios) para o tratamento de águas residuárias, operados com altas concentrações de SST (5000 mg. $\left.\mathrm{L}^{-1}\right)$ e TCOV de 4,55 a 18,65 kg DQO. $\mathrm{m}^{-3} \cdot \mathrm{d}^{-1}$ no primeiro reator e de 2,55 a 21,03 $\mathrm{kg}$ DQO. $\mathrm{m}^{-3} \cdot \mathrm{d}^{-1}$ no segundo reator, permitiram apresentar as conclusões abaixo relacionadas, as quais serão descritas em relação aos objetivos estabelecidos e apresentados no item 1.

a) Em relação ao objetivo de verificar o efeito do afluente (águas residuárias de suinocultura) com concentração de SST em torno de $5000 \mathrm{mg} . \mathrm{L}^{-1}$ no desempenho dos reatores UASB operados em dois estágios e com diferentes TCOV, pode-se concluir que:

- as condições impostas aos reatores na fase inicial de operação: inoculação com lodo granulado, aplicação de taxas de carregamento no lodo (TCL) no primeiro reator de 0,1 a $0,2 \mathrm{~kg} \mathrm{DQO}$ total. $\mathrm{kg} \mathrm{SV}^{-1} \cdot \mathrm{d}^{-1}$ e baixas TCOV (1,79 $\mathrm{kg}$ DQO. $\mathrm{m}^{-3} \cdot \mathrm{d}^{-1}$ no primeiro reator), sem recirculação do efluente, propiciaram partida rápida do sistema (em torno de 20 dias) e manutenção do lodo granulado, mesmo com o afluente com altas concentrações de SST (em torno de $2000 \mathrm{mg} . \mathrm{L}^{-1}$ );

- os reatores UASB instalados em série foram eficientes na remoção de DQO da fração dissolvida e, principalmente, da fração devido à concentração de SST do afluente. Para TCOV de 4,55 e 2,55 kg DQO. $\mathrm{m}^{-3} \cdot \mathrm{d}^{-1}$ no primeiro e segundo reatores, respectivamente, pôde-se obter eficiências de remoção de DQO $_{\text {total }}$ e de SST acima de $90 \%$ e de $\mathrm{DQO}_{\text {dissolvida }}$ acima de $85 \%$. Para TCOV de 18,65 e 21,03 kg DQO.m ${ }^{-3} \cdot \mathrm{d}^{-1}$ no primeiro e segundo reatores, respectivamente, as eficiências de remoção de DQO $_{\text {total }}$ e de SST foram acima de 70\% e DQO dissolvida acima de 75\%. As maiores produções específicas de metano foram obtidas com TCOV de 2,55 kg DQO.m ${ }^{-3} \cdot \mathrm{d}^{-1}$ para o segundo reator e de $8,65 \mathrm{~kg}$ DQO. $\mathrm{m}^{-3} \cdot \mathrm{d}^{-1}$ para o primeiro reator; 
- a conversão da DQO em metano nos reatores UASB pareceu estar associada à participação da $\mathrm{DQO}_{\text {dissolvida }}$ na $\mathrm{DQO}_{\text {total }}$ do afluente e às características de biodegradabilidade dos SST presentes no afluente. Para TDH mais altos e temperatura controlada na faixa de 25 a $30^{\circ} \mathrm{C}$, o desempenho é melhorado, mesmo com o afluente com altas concentrações de SST;

- as eficiências de remoção de NTK e $\mathrm{N}_{\text {org. }}$ foram mais altas para o s maiores TDH e menores TCOV (4,55 e 8,75 kg DQO. $\mathrm{m}^{-3} \cdot \mathrm{d}^{-1}$ no primeiro reator);

- a relação AI:AP apresentou-se como um parâmetro útil para o acompanhamento da estabilidade dos reatores UASB, permanecendo próxima da faixa indicada para reatores operados em condições de equilíbrio e tendo sido de fácil obtenção analítica;

- o descarte periódico de lodo, da parte superior da manta onde houve maior acúmulo de lodo suspenso e floculento, deve ser considerado como uma medida necessária quando forem operados reatores UASB com afluentes com altas concentrações de SST, como as provenientes da suinocultura. A peridiocidade de descarte do lodo para a concentração de SST utilizada (em torno de $5000 \mathrm{mg} . \mathrm{L}^{-1}$ ) foi de 30 a 40 dias.

b) Com relação ao objetivo de verificar o comportamento da manta de lodo, dos reatores UASB operados em dois estágios, quanto ao crescimento e distribuição de populações microbianas, pode-se concluir que:

- a composição das águas residuárias de suinocultura pode ter favorecido a manutenção do lodo granulado, em virtude de conter $\mathrm{N}_{\mathrm{am}}$. em concentrações não limitantes ao processo de digestão anaeróbia e alta participação de SSV nos SST (acima de 90\%);

- a operação dos reatores UASB com valores de concentração de SST no afluente em torno de $5000 \mathrm{mg} . \mathrm{L}^{-1}$ foram prejudiciais ao processo de granulação do lodo. Os grânulos apresentaram-se pequenos e irregulares, constituídos predominantemente de arqueas e bactérias;

- os grânulos observados, de coloração preta, estiveram presentes em todas as regiões da manta de lodo dos reatores. Apresentaram distribuição dispersa das morfologias microbianas ao longo da parede, não caracterizando a divisão em camadas definidas;

- a formação do grânulo sem apresentar estrutura em camadas definidas pareceu estar associada às altas concentrações de SST no afluente (em torno de $5000 \mathrm{mg} . \mathrm{L}^{-1}$ ) e às altas proporções de DQO devido a fração de SS (70 a 75\% da DQO $\mathrm{total}_{\text {) }}$;

- nos grânulos examinados, as arqueas metanogênicas predominantes foram as semelhantes à Methanosaeta na forma de bacilos curtos aglomerados. Isto pode ser 
atribuído a fatores como: a origem do lodo de inóculo, a manutenção nos reatores de concentrações de AVT sempre baixas, em torno de $100 \mathrm{mg} \cdot \mathrm{L}^{-1}$ e a composição da água residuária afluente, contendo, principalmente, carboidratos, proteínas e lipídeos;

- a acumulação de lodo nos reatores UASB foi diretamente influenciada pela concentração de SST do afluente. O aumento da TCOV, em torno de 18 kg DQO.m ${ }^{3} \cdot \mathrm{d}^{-1}$, diminuiu a acumulação de lodo nos reatores UASB, em virtude da remoção física do lodo por arraste de lodo granulado e floculento suspensos.

c) Em relação ao objetivo de sugerir valores de taxas de carregamento orgânico volumétrico (TCOV) e tempo de detenção hidráulica (TDH) para o projeto e operação de reatores UASB em dois estágios para o tratamento de águas residuárias provenientes da suinocultura, na faixa de concentração de SST estudada, pôde-se obter, a partir da transcrição de conclusões anteriormente apresentadas, que:

- a inoculação com lodo granulado, aplicação de taxas de carregamento no lodo (TCL) no primeiro reator de 0,1 a $0,2 \mathrm{~kg}$ DQO $_{\text {total. }} \mathrm{kg} \mathrm{SV}^{-1} \cdot \mathrm{d}^{-1}$ e baixas TCOV $(1,79 \mathrm{~kg}$ DQO. $\mathrm{m}^{-3} \cdot \mathrm{d}^{-1}$ no primeiro reator), sem recirculação do efluente, podem propiciar a partida rápida do sistema (em torno de 20 dias) e manutenção do lodo granulado, mesmo com o afluente com altas concentrações de SST (em torno de $2000 \mathrm{mg} . \mathrm{L}^{-1}$ );

- o principal parâmetro de projeto para afluentes com concentrações de SST em torno de $5000 \mathrm{mg} . \mathrm{L}^{-1}$ é a TCOV e o TDH e não a concentração de SST do afluente;

- o descarte periódico de lodo, da parte superior da manta onde houve maior acúmulo de lodo suspenso e floculento, deve ser considerado como uma medida necessária quando forem operados reatores UASB com afluentes com altas concentrações de SST, como as provenientes da suinocultura. A peridiocidade de descarte do lodo para a concentração de SST utilizada (em torno de $5000 \mathrm{mg} . \mathrm{L}^{-1}$ ) foi de 30 a 40 dias. 


\section{RECOMENDAÇÕES}

- Utilizar outros tipos de lodo de inóculo, em virtude da dificuldade de obtenção de lodo granulado, mantendo-se os procedimentos de partida adotados neste trabalho para os reatores UASB tratando águas residuárias contendo altas concentrações de SST, provenientes da suinocultura.

- Estudar o efeito de concentrações de SST do afluente mais elevadas, com os mesmos TDH utilizados neste trabalho, para a operação de reatores UASB alimentados com águas residuárias de suinocultura, visando o estabelecimento de limites mais amplos.

- Avaliar o desempenho de outros reatores anaeróbios de alta taxa, no sistema em dois estágios, para o tratamento de águas residuárias de suinocultura.

- Estudar a utilização de outros volumes de reatores UASB em dois estágios. Verificar o desempenho do sistema com a utilização de reatores com menor volume no primeiro estágio e maior volume no segundo estágio (escala de volume 3:1, 2:1 e 1:1).

- Aprimorar as determinações das produções de biogás e de lodo, para obtenção de balanços de massa mais confiáveis e precisos.

- Aprofundar o estudo de microrganismos hidrolíticos presentes em reatores UASB. 


\section{REFERÊNCIAS BIBLIOGRÁFICAS}

ABCS - Associação Brasileira de Criadores de Suínos. Rebanho Suíno. (2004). ConcórdiaSC, SNDS.

APHA, AWWA, WPCF. Standard methods for the examination of water and wastewater. (1992).18th edition, Washington D.C, American Public Health Association.

ARAÚJO, J.C. et al. (2000). The use of fluorescence in situ hybridization to evaluate microbial composition of the anaerobic sludge and biofilms in wastewater treatment systems. In: OFICINA E SEMINÁRIO LATINO-AMERICANO DE DIGESTÃO ANAERÓBIA, VI, 05 a 09 de novembro de 2000, Recife-PE. Anais, Recife-PE, Editora Univ. da UFPE, p.285292, v.1.

BANIK, G.C., ELLIS, T.G., DAGUE, R.R. (1997). Structure and methanogenic activity of granules from an ASBR treating dilute wastewater at low temperatures. Department of Civil and Construction Engineering, Iowa State University Ames. Water Science and Technology, v.36, n. 6-7, p.149-156.

BRANDÃO, V.S. et al. (2000). Tratamento de águas residuárias da suinocultura utilizandose filtros orgânicos. Revista Brasileira de Engenharia Agrícola e Ambiental, v.4, n.3, p. 327333.

CHERNICHARO, C.A.L. (1997). Reatores Anaeróbios. Departamento de Engenharia Sanitária e Ambiental - UFMG. Belo Horizonte. 246p.

CINTOLI, R. et al. (1995). Ammonium uptake by zeolite and treatment in UASB reactor of piggery wastewater. Water Science and Technology, v.32, n.12, p.73-81. 
COBB, S.A., HILL, D.T. (1989). A comparative analysis of two synthetic media for suspended particle-attached growth anaerobic fermentation. Transactions of ASAE, v.32, n.1, p.223-227.

DEL NERY, V. (1993). Digestão anaeróbia em duas fases com culturas mistas acidogênicas e metanogênicas imobilizadas separadamente em gel agar. Tese (doutorado). Escola de Engenharia de São Carlos, Universidade de São Paulo, São Carlos-SP.

DILALlO, R., ALBERTSON, O.E. (1961). Volatile acids by direct titration. Journal WPCF, v.33, p.356-365.

GUIOT, S.R., PAUSS, A., COSTERTON, J.W. (1991). A structured model of the anaerobic granule consortium. Water Science and Technology, 25,7, p.1-7.

HASHEIDER, R.J., SIEVERS, D. (1984). Limestone bed anaerobic filter for swine manure laboratory study. Transactions of the ASAE, v.27, n.3, p.834-839.

HOLMBERG, R.D., HILL, D.T., PRINCE, T.J., VANDYKE, N.J. (1983). Potential of solidliquid separation of swine wastes for methane production. Transactions of the ASAE, v.26, n.6, p.1803-1807.

HULSHOFF POL, L.W. (1989). The phenomenon of granulation of anaerobic sludge. (Ph.D). thesis. Agricultural University of Wageningen. Wageningen. The Netherlands, 122 p.

JENKINS, S.R., MORGAN, J.M., SAWYER, C.L. (1983). Measuring anaerobic sludge digestion and growth by a simple alkalimetric titration. Journal WPCF, v.55, n.5, p.448-453.

JÚNIOR, C.B. (1999). Suinocultura e meio ambiente. Florianópolis-SC, Ecoltec.

KALYUZHNYI, S. et al. (2000). Integrated mechanical, biological and physico-chemical treatment of liquid manure streams. Water Science and Technology, v.41, n.12, p.175-182.

KALYUZHNYI, S. et al. (1999). The development of biological methods for utilisation and treatment of diluted manure streams. Water Science and Technology, v.40, n.1, p.223-230.

LETTINGA, G. (1996). Sustainable integrated biological wastewater treatment. Water Science and Technology, v.33, n.3, p.85-98. 
LETTINGA, G., HULSHOFF-POL, L.W. (1991). UASB-process design for various types of wastewaters. Water Science and Technology, v.24, n.8, p.87-107.

LETTINGA, G. et al. (1980). Use of the upflow sludge blanket (USB) reactor concept for biological wastewater treatment especially anaerobic treatment. Biotechnology and Bioengineering, v.22, n.4, p.699-734.

LO, K.V., LIAO, P.H., GAO, Y.C. (1994). Anaerobic treatment of swine wastewater using hybrid UASB reactors. Bioresource Technology, v.47, p.153-157.

MACLEOD, F.A., GUIOT, S.R., COSTERTON, J.W. (1990). Layered structure of bacterial aggregates produced in a upflow anaerobic sludge bed and filter reactor. Applied and Environmental Microbiology, v.6, p.1598-1607.

MONTALVO, S. (1995). Industrial and rural piggeries wastewaters. In: INTERNATIONAL COURSE: TREATMENT OF AGRO-INDUSTRIAL RESIDUES, Ciudad de México. Proceedings. Ciudad de México, Universidad Nacional Autónoma de México, p.102-117.

MORAES, E. M. et al. (2000). Determinação de Ácidos Voláteis por Cromatografia Gasosa em Efluentes de Reatores Anaeróbios Tratando Resíduos Líquidos e Sólidos. In: OFICINA E SEMINÁRIO LATINO-AMERICANO DE DIGESTÃO ANAERÓBIA, VI, 05 a 09 de novembro de 2000, Recife-PE. Anais, Recife-PE, Editora da UFPE, , p.235-238, v.2.

NG, W.I., CHIN, K.K. (1988). Treatment of piggerry wastewater by expanded-bed anaerobic filters. Biological Wastes, v.26, n.3, p.215-228.

OLESZKIEWICZ, I.A. (1983). A comparison of anaerobic treatments of low concentration piggery wastewaters. Agricultural Wastes, v.8, n.4, p.215-231.

OLIVEIRA, P.A.V., COSTA, R.H.R., TROGLIO, J. (1995). Lagoons for treatment of waste products from hogs: example of Coopercentral. In: INTERNATIONAL CONFERENCE AND WORKSHOP ON WASTE STABILIZATION PONDS TECHNOLOGY AND APPLICATIONS, 3rd, João Pessoa-PB - Brasil. Preprint volume. João Pessoa, IAWQ, 6p.

OLIVEIRA, P.A.V. et al. (1996). Impacto ambiental causado pelos dejetos de suínos. Concórdia, SC., Embrapa-CNPSA, 13p. 
OLIVEIRA, P.A.V. et al. (1993). Manual de manejo e utilização dos dejetos de suínos. Concórdia - Santa Catarina, CNPSA-EMBRAPA, (Documento no. 27).

OLIVEIRA, R.A. (2001). Efeito da carga hidráulica volumétrica, da temperatura climatólogica e do descarte do excesso de lodo da manta no desempenho de reatores UASB tratando águas residuárias de suinocultura. Jaboticabal, FCAV - UNESP, Campus de Jaboticabal, 125 p. (Relatório final de pesquisa CPA/UNESP).

OLIVEIRA, R.A. (2000). Tratamento anaeróbio em reatores UASB do resíduo bruto de suinocultura com uso intensivo de água de higienização. Jaboticabal, FCAV - UNESP, Câmpus de Jaboticabal, 240 p. (Relatório final de pesquisa CPRT/UNESP).

OLIVEIRA, R.A. (2000). Influência da aplicação de águas residuárias de suinocultura na capacidade de infiltração de um solo Podzólico Vermelho-Amarelo. Revista Brasileira de Engenharia Agrícola e Ambiental, v.4, n.2, p.263-267.

OLIVEIRA, R. A. (1997). Efeito da concentração de sólidos suspensos do afluente no desempenho e características do lodo de reatores anaeróbios de fluxo ascendente com manta de lodo tratando águas residuárias de suinocultura. São Carlos-SP, 389p, v.1 e 2, Tese (Doutorado). Escola de Engenharia de São Carlos, Universidade de São Paulo.

PAVLOSTATHIS, S.G., GIRALDO-GOMEZ, G.E. (1991). Kinetics of anaerobic treatment. Water Science and Technology, v.24, n.8, p.35-59.

PEREIRA-RAMIREZ, O., QUADRO, M.S., ANTUNES, R.M., KOETZ, P.R. (2003). Remoção de carga orgânica e nitrogênio dos dejetos de suínos. Sociedade Brasileira de Engenharia Agrícola. XXXII Congresso Brasileiro de Engenharia Agrícola - CONBEA, Goiânia.

RIPLEY, L.E., BOYLE, WC., CONVERSE, J.C. (1986). Improved alkalimetric monitoring for anaerobic digestion of high-strength wastes. Journal WPCF, v.58, n.5, p.406-411.

SANCHEZ, E.P. et al. (1995). Piggery waste treatment by anaerobic digestion and nutrient removal by ionic exchange. Resources, Conservation and Recycling, v.15, p.235-244. 
SAMSON, R., PAUSS, A., GUIOT, S.R. (1990). Immobilized systems in anaerobic digestion processes. In: R. D. Tyagi and K. Vembu (ed). Wastewater treatment by immobilized cells. CRC Press. Boca Raton, FL., p. 153-190.

SAYED, S.K.I., FERGALA, M.A.A. (1995). Two-stage UASB concept for treatment of domestic sewage including sludge stabilization process. Water Science and Technology,v.32, n.11, p.55-60.

SAYED, S.K.I., VAN DER SPOEL., H., TRUIJEN, G.J.P. (1993). A complete treatment of slaughterhouse wastewater combined with sludge stabilization using two stage high rate UASB process. Water Science and Technology, v.29, n.9, p.83-90.

SAYED, S.K.I. (1987). Anaerobic treatment of slaughterhouse wastewater using the UASB process. Wageningen - The Netherlands, 134p. Tese (Ph.D) - Wageningen Agricultural University.

SCHMIDT, J.E., AHRING, B.K. (1996). Granular sludge formation in upflow anaerobic sludge blanket (UASB) reactors. Biotechnology and Bioengineering, v.49. p.229-246.

SEGHEZZO, L. et al. (1998). A review: the anaerobic treatment of sewage in UASB and EGSB reactors. Bioresource Technology, v.65, p.175-190.

SEKIGUCHI, Y. et al. (1999). Fluorescence in in situ hybridization using $16 S$ rRNA-targeted oligonucleotides reveals localization of methanogens and thermophilic sludge granules. Applied and Enviromental Microbiology, p. 1280-1288.

SINGH, R.P., KUMAR,S., OJHA,C.S.P. (1999). Nutrient requirement for UASB process: a review. Biochemical Engineering Journal, v.3, p. 35-54.

VANDERHAEGEN, B. et al. (1991). Acidogenesis in relation to in reactor granule yield. In: Anaerobic digestion, São Paulo, Brazil, p. 21-30.

VAN HAANDEL, A.C., LETTINGA, G. (1994). Anaerobic sewage treatment. A pratical guide for regions with a hot climate. Chichester, John Wiley and Sons Ltda.

VAN LIER, J.B. et al. (2001). New perspectives in anaerobic digestion. Water Science and Technology, v. 43, n.1, p.1-18. 
VARESCHE, M.B.A. et al. (2000). Quantificação da biomassa de um bioreator termofilico utilizando a técnica do número mais provável (NMP) com diferentes substratos orgânicos e fonte de enxofre. In: OFICINA E SEMINÁRIO LATINO-AMERICANO DE DIGESTÃO ANAERÓBIA, VI, 05 a 09 de novembro de 2000, Recife-PE. Anais, Recife-PE, Ed. Univ. UFPE, p.285-292, v.2.

VIÑAS, M., GARCIA, R., RUBIO, N. (1995). Anaerobic digestion of animal wastes in UASB reactor. In: INTERNATIONAL SYMPOSIUM ON WASTE MANAGEMENT PROBLEMS IN AGRO-INDUSTRIES, 3rd, Mexico City,. Proceedings. Mexico City, IAWQ, p. 195-201.

YANG, P.Y., CHOU, C.Y. (1985). Horizontal-baffled anaerobic reactor treating diluted swine wastewater. Agricultural Wastes, v.14, p.221-239.

ZHU, J. (2000). A review of microbiology in swine manure odor control. Agriculture, Ecosystems and Environment, v.78, p.93-106. 